
PETROLEUM GEOLOGY OF NAVAL PETROLEUM RESERVE NO. 1, ELK HILLS, KERN COUNTY, CALIFORNIA 


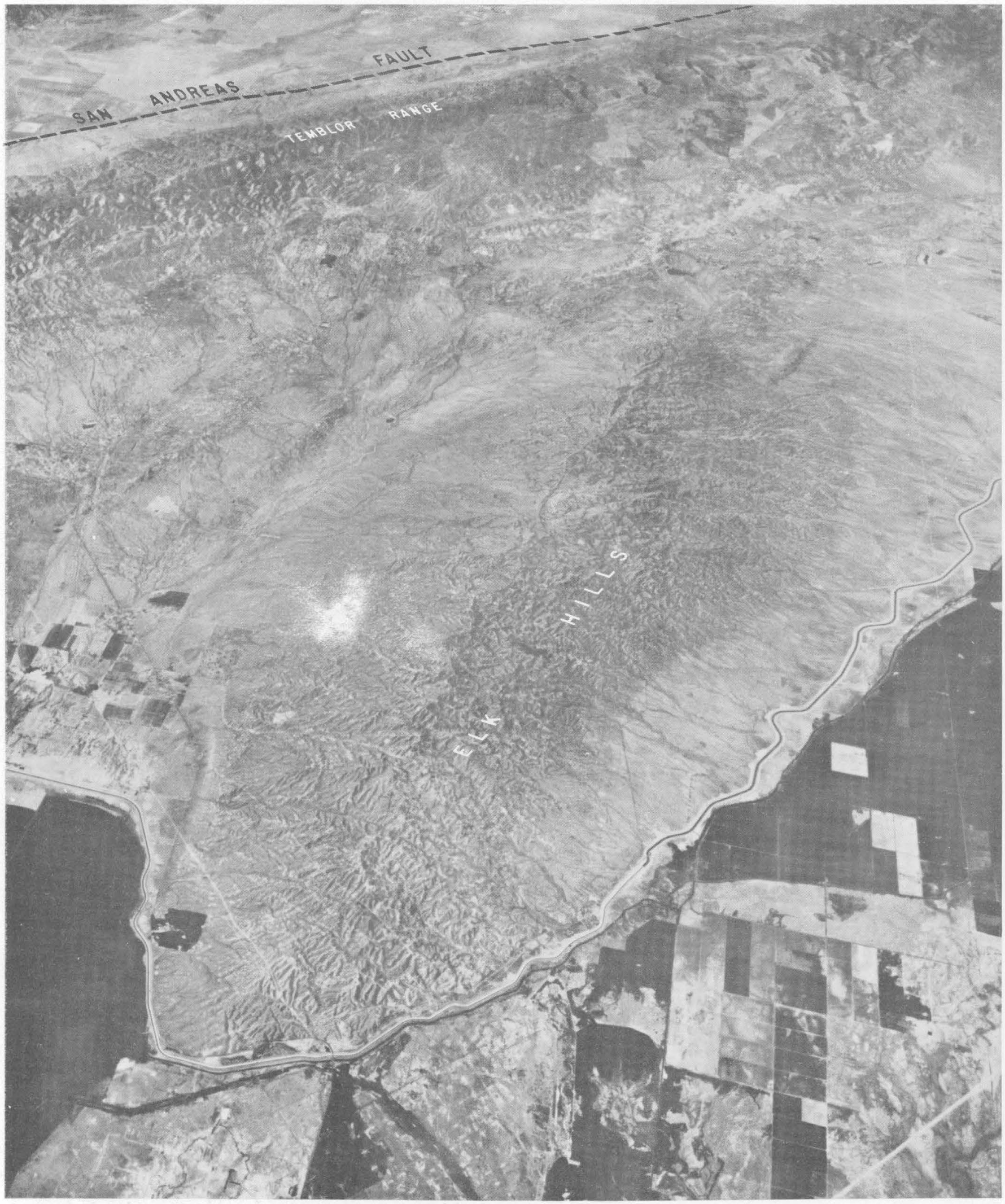

Aerial photograph of Elk Hills, looking west, showing angular relation to the Temblor Range and the San Andreas fault. 


\section{Petroleum Geology of}

Naval Petroleum Reserve No. 1,

Elk Hills, Kern County, California

By J. C. MAHER, R. D. CARTER, and R. J. LANTZ

With a section on CHANNEL TURBIDITE SANDSTONES IN THE ELK HILLS SHALE MEMBER OF THE MONTEREY SHALE By' K. T. BIDDLE, J. C. MAHER, and R. D. CARTER

GEOLOGICAL SURVEY PROFESSIONAL PAPER 912 


\section{UNITED STATES DEPARTMENT OF THE INTERIOR}

ROGERS C. B. MORTON, Secretary

\section{GEOLOGICAL SURVEY}

V. E. McKelvey, Director

Library of Congress Cataloging in Publication Data

Maher, John Charles, 1914-

Petroleum geology of Naval Petroleum Reserve No. 1, Elk Hills, Kern County, California.

(Geological Survey Professional Paper 912)

Supt. of Docs. No.: I 19.16:912

Bibliography: p. 104-109.

1. Petroleum-Geology-California-Elk Hills. I. Carter, R. D., joint author. II. Lantz, Robert Joseph, 1922 joint author. III. Title. IV. Series: United States. Geological Survey. Professional Paper 912. TN872.C2M33 $553^{\prime} .282^{\prime} 0979488$ 74-28002

For sale by the Superintendent of Documents, U.S. Government Printing Office Washington, D.C. 20402

Stock Number 024-001-02606 


\section{CONTENTS}

Abstract

Introduction -

Location of study area and purpose of report

Previous investigations

Present investigations

Location and numbering system of wells

Published base maps _.

Acknowledgments

Geography

Area and accessibility

Topography

Water supply

Ground water

History of Naval Petroleum Reserve No. 1

Early operations in the southwestern

San Joaquin Valley

Development of seeps and asphalt deposits

Development of appreciable oil production .........

Gushers of the Midway-Sunset field

Drilling in the Buena Vista Hills

Discovery of oil at Elk Hills

Withdrawal of public oil lands

Conservation movement

Oil-field waste and its legal cause ................

Role of the U.S. Geological Survey _._.

Effect of withdrawal order

Railroad land _... 24

Establishment of Naval Petroleum Reserve No. 1 ....... 24 Recommendations of U.S. Geological Survey _..... 24 Area and ownership _.......................... 24

Operation of Naval Petroleum Reserve No. 1 ......... 24 Creation of Naval Petroleum Reserves No. 2 and 3 -- 24

Litigation over railroad land _._._._._._._._-_._. 25

Hay-Carman and Tupman discoveries on school land

Oil- and gas-leasing law

Navy control

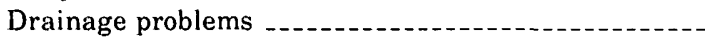

Transfer of Naval Petroleum Reserves to Interior

Cancellation of school-land lawsuit

Royalty bidding for offset wells

Crude-oil exchange for Pearl Harbor construction

Senate investigations and results

School-land recovery

Return to Navy control

Proposed exchange of Elk Hills and Buena Vista

Hills leases

Unitization during World War II

Postwar additions and status of reserve in 1973

Regional geologic setting .......

Tectonic elements

Sierra Nevada

Coast Ranges 37

Central Valley _. 39

Stratigraphic sequence
Structural geology

Structure of surface rocks _._.

Structure of subsurface rocks _._._. 43

Upper Miocene rocks _-_._. 43

Pliocene rocks -

Structural relations._._._._._._._. 44

Fault system of the Eastern anticline

Late Tertiary structural history _._._._._.

Stratigraphy _._. 48

Stratigraphic sections ..._.

Nomenclature _...... 48

Oil-field terminology _..... 48

Fossil horizons _...

Electric-log horizons _. 51

Relative self potential

Reference sections at Elk Hills

Rocks of Mesozoic age

Rocks of Eocene age _._.

Kreyenhagen Formation

Gredal Shale Member._._._._._. 53

Point of Rocks Sandstone Member

Welcome Shale Member._._._._. 54

Rocks of Oligocene age _._._._._. 54

Wagonwheel Formation _..._.

Rocks of Oligocene and early Miocene age _._._._. 55

Temblor Formation _._. 55

Cymric Shale Member _._._._._._._._._. 56

Wygal Sandstone Member.......... 56

Santos Shale Member.

Carneros Sandstone Member

Media Shale Member _._._._. 57

Rocks of middle and late Miocene age _._._._._._. 58

Monterey Shale __-_._. 58

Gould and Devilwater Shale Members,

undifferentiated _............ 59

McDonald shale of local usage _..._._._. 60

Elk Hills Shale Member _._._._._._._._. 61

Reef Ridge Shale _._. 65

Rocks of Pliocene age _._. 66

Etchegoin Formation

Tupman Shale Member _._._. 68

Olig sand zone

Buliminella silt zone _...... 69

Carman Sandstone Member _._._._._. 69

Calitroleum sand zone _..... 71

Gusher sand zone._._._. 71

Wilhelm sand zone _._._._._._. 72

Mulinia sand zone _....... 72

San Joaquin Formation

Scalez sand zone _._.

Mya sand zone

Rocks of Pliocene and Pleistocene age _._. 75

Tulare Formation _._. 75

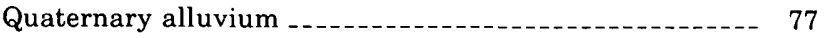

Depositional summary 
Channel turbidite sandstones in the Elk Hills Shale Member of the Monterey Shale, by K. T. Biddle, J. C. Maher, and R. D. Carter

Sedimentary structures

Petrography

Source and deposition

Oil and gas

Productive zones

History of development

Santos Oil Zone

Carneros Oil Zone

Stevens Oil Zone

D zone

C zone
Page 80 81 84 . 85 85 86 .87 90 90 96 96
Oil and gas-Continued Stevens Oil Zone-Continued

B zone

A zone

$\mathrm{N}$ zone -1

Sand-body reservoirs transecting zones_........ 97

Shallow Oil Zone -97

Dry Gas Zone

Production and reserves_-_- 99

Origin and accumulation of petroleum at Elk Hills _...... 100

Future exploration -102

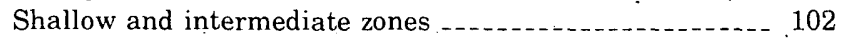

Deep zones

References cited

\section{ILLUSTRATIONS}

[Plates are in separate case ]

Frontispiece. Aerial photograph of Elk Hills showing angular relation to Temblor Range and San Andreas fault.

Plate 1. Topographic map of Elk Hills and vicinity.

2. Location of wells in Naval Petroleum Reserve. No. 1 and selected wells in adjacent oil fields.

3. Areal geology and structure of Elk Hills.

4. Maps showing structure contours drawn on top of Elk Hills Shale Member of Monterey Shale, Reef Ridge Shale, and Scalez horizon in lower part of San Joaquin Formation.

5. Structure sections of Elk Hills.

6. Structure contour and isopach maps showing anticlinal growth and its cumulative effect on sedimentation in upper Miocene and younger rocks at Elk Hills.

7. Stratigraphic section AF of Miocene and older Tertiary rocks from Railroad Gap across Elk Hills to North Coles Levee.

8. Stratigraphic section AB of Miocene and younger rocks from well 555-15Z, Railroad Gap, to well 555-30R, Elk Hills.

9. Stratigraphic section BC of Miocene and younger rocks from well 555-30R to well 316-26R, Elk Hills.

10. Stratigraphic section CD of Miocene and younger rocks from well 316-26R to well 562-31S, Elk Hills.

11. Stratigraphic section DE of Miocene and younger rocks from well 562-31S to well 386-34S, Elk Hills.

12. Stratigraphic section EF of Miocene and younger rocks from well 386-34S, Elk Hills, to well CLA-67-29T, North Coles Levee.

13. Stratigraphic section $\mathrm{GH}$ of Miocene and younger rocks from well 354-26Z, Asphalto, northeastward to well 314-18R, Elk Hills.

14. Stratigraphic section IJ of Miocene and younger rocks from well 377-30R northward to well 18-6R, Elk Hills.

15. Stratigraphic section KL of Miocene and younger rocks from well 86-1B northward to well 44-24R, Elk Hills.

16. Stratigraphic section MN of Miocene and younger rocks from well 78-11G northward to well 321-26S, Elk Hills.

17. Composite electric log showing terminology for Shallow Oil Zone in Elk Hills oil field.

18-25. Maps showing:

18. Thickness and producing wells of $\mathrm{C}$ and B zones of Elk Hills Shale Member of Monterey Shale.

19. Thickness and producing wells of $A$ and $N$ zones of. Elk Hills Shale Member of Monterey Shale.

20. Thickness of Reef Ridge Shale and Etchegoin Formation.

21. Thickness and relative self potential of Tupman Shale and Carman Sandstone Members of Etchegoin Formation.

22. Thickness and producing wells of Calitroleum and Gusher sand zones of Carman Sandstone Member of Etchegoin Formation.

23. Thickness and producing wells of Wilhelm and Mulinia sand zones of Carman Sandstone Member of Etchegoin Formation.

24. Thickness and relative self potential of San Joaquin Formation and thickness of Tulare For mation.

25. Thickness and producing wells of Scalez and Mya sand zones of San Joaquin Formation.

1. Map showing location of the.Elk Hills oil field, San Joaquin Valley, Calif

2. Photograph of Tupman Camp area, Elk Hills, about 1921

3. Diagram showing well spacing and numbering system for the Elk Hills oil field

4. Map showing settlements, railroads, and place names in southwestern San Joaquin Valley, 1908

5. Photograph of Elk Hills as viewed from the North Coles Levee oil field

6. Photograph of characteristic terrain in Elk Hills

7. Map showing Kern River alluvial. fan and major historical channels of Kern River

8. Map showing location and classification of water wells in Elk Hills area 
Ficiure 9. Diagram showing system of numbering water wells

10. Aerial view of Midway-Sunset field about 1940

11. Burning gusher in the Midway-Sunset field about 1910

12. Lakeview gusher in the Midway-Sunset oil field _..

13. Wooden derrick of cable-tool rig in the Buena Vista oil field

14. Old bull wheel from cable-tool rig -

15. Steel derrick in the Buena Vista oil field

16. Map showing area, land ownership, boundary, and location of oil wells in Naval Petroleum Reserve No. 1 when established September 2, 1912

17. Map showing land ownership of Naval Petroleum Reserve No. 1 after United States Supreme Court decision of Novem. ber 1.7, 1919

18. Photograph of Hay No. 7 well, Elk Hills _......

19. Photograph of Hay No. 8 gas well burning in 1920

20. Map showing leases issued in Naval Petroleum Reserve No. 1, 1921 and 1922

21. Photograph of wells on the Hay lease (36R) in Elk Hills about 1922

22. Photograph of Pan American Oil Company 2G Camp in the Elk Hills oil field, December 1924

23. Map showing land ownership of Naval Petroleum Reserve No. 1 after decisions of General Land Office, March 24, 1938, and U.S. Supreme Court, March 25, 1940

24. Photograph of eastern part of the Elk Hills oil field as developed by June 1941 25-29. Maps showing:

25. Area, land ownership, and boundary of Naval Petroleum Reserve No. 1 after Executive Order of October 15, 1942

26. Present area, land ownership, and boundary of Naval Petroleum Reserve No. 1 in 1973

27. Location of the Elk Hills oil field in relation to regional tectonic elements

28. Regional structure in relation to oil and gas fields of southern San Joaquin Valley

29. Lines of structure sections across the Elk Hills oil field

30. Structure section showing fault system of the Eastern anticline

31. Sections showing structural development along line AE from Railroad Gap to eastern Elk Hills

32. Map showing lines of stratigraphic sections across the Elk Hills oil field

33. Diagram showing composite electric log and terminology for Stevens Oil Zone in the Elk Hills oil field .............

34. Map showing location of Elk Hills in relation to most outcrop localities discussed in this report

35. Map showing thickness of $24 \mathrm{Z}$ (Asphalto) sand facies in the Asphalto oil field and western part of the Elk Hills oil field

36. Map showing thickness of $26 \mathrm{R}$ sand facies in central part of the Elk Hills oil field

37. Map showing thickness of Olig sand zone in the Railroad Gap and Asphalto oil fields and western part of the Elk Hills oil field'

38. Photograph of Tulare Formation in eastern Elk Hills

39. Biostratigraphic section of southern part of San Joaquin Valley

40-46. Photographs showing:

40. Contorted bedding in core from $26 \mathrm{R}$ sand

41. Graded bedding, carbonaceous plant fragments, and shale chips in core from $24 \mathrm{Z}$ sand $\ldots \ldots \ldots$

42. Graded bedding in core from $24 \mathrm{Z}$ sand ...............

43. Graded bedding and cross laminations in core from $24 \mathrm{Z}$ sand

44. Flattened rip-up clasts of shale, large carbonaceous plant fragments, and "floating" very coarse sand grains in core from $26 \mathrm{R}$ sand

45. Worm burrow in fine-grained sandstone cored from $24 \mathrm{Z}$ sand

46. Structureless granule conglomerate cored from $24 \mathrm{Z}$ sand

47. Triangular diagram showing composition of $24 \mathrm{Z}$ sand and $26 \mathrm{R}$ sand

48. Triangular diagram showing composition of clasts of granitic rocks in cores of $24 \mathrm{Z}$ sand

49. Photograph of large carbonaceous plant fragments in fine-grained sandstone cored from $26 \mathrm{R}$ sand.........

50. Graph showing yearly and cumulative production of oil recorded since establishment of Naval Petroleum Reserve

No. 1 _

51. Sketch map showing oil fields that extend onto Naval Petroleum Reserve No. 1

\section{TABLES}

TABLE

1. Description of water wells in Elk Hills area

2. Chemical analyses of waters from water wells in the Elk Hills area

3. Stratigraphic units and their approximate thicknesses in Elk Hills and vicinity

4. Oil and gas reservoirs, producing zones, production, and reserves of Naval Petroleum Reserve No. 1, 1972 
5. Porosity and permeability for cores from wells drilled in Naval Petroleum Reserve No. 1 .

6. Analyses of crude petroleum from wells in Naval Petroleum Reserve No. 1

7. Selected chemical analyses of formation waters from wells in Naval Petroleum Reserve No. 1 


\title{
PETROLEUM GEOLOGY OF NAVAL PETROLEUM RESERVE NO. 1, ELK HILLS, KERN COUNTY, GALIFORNIA
}

\author{
By J. C. Maher, R. D. Carter, and R. J. Lantz
}

\section{ABSTRACT}

Naval Petroleum Reserve No. 1 encompasses the Elk Hills oil field and small parts of the Railroad Gap, Asphalto, Buena Vista Hills, and North Coles Levee oil fields in the southern San Joaquin Valley of California. It consists of 46,095 acres, on which are nearly 1,000 oil wells ready for production.

The Elk Hills oil field, which constitutes the largest part of Naval Petroleum Reserve No. 1 (NPR-1), is located about 20 miles southwest of Bakersfield and about 9 miles north of Taft. The field extends over part of a large anticlinal trend whose surface expression is a line of hills about 17 miles long and 7 miles wide. Elk Hills field is classed among the giant petroleum fields of the world. Ultimate recoverable reserves are presently estimated to be more than 1.3 billion barrels of oil of which less than 300 million barrels have been produced.

The United States Government owns about 80 percent and the Standard Oil Company of California about 20 percent of the reserves within the Elk Hills oil field. Because of this divided ownership, the field is operated as a unit under an agreement between the Office of Naval Petroleum and Oil Shale Reserves of the Department of the Navy, and the Standard Oil Company of California.

Oil seeps and asphalt deposits in the southwestern San Joaquin Valley led to oil drilling there as early as 1864 . In the early part of the 20th century, spectacular gushers were found in the Midway-Sunset area. With these successes drillers moved out from the foothills of the Temblor Range into the Buena Vista Hills and from there toward Elk Hills. The remaining public lands in Elk Hills and vicinity were withdrawn from all forms of entry in September 1909 by President Taft upon the recommendations of the Director of the U.S. Geological Survey. Despite this, more than 20 wells were started during 1910, and oil was discovered at Elk Hills in 1911. However, the Standard Oil Company (California) No. 1 Hay well drilled in 1919 is generally regarded as the discovery well.

Naval Petroleum Reserve No. 1 was established September 2, 1912. During the next 35 years, the hundreds of wells drilled at Elk Hills were nearly equaled by the lawsuits and other differences between the Government and oil companies. Responsibility for the reserve was transferred from the Navy to the Department of the Interior and finally back to the Navy after the Teapot Dome scandal, which involved leases at Elk Hills as well as at Teapot Dome, Wyo. By means of agreements between the Navy and Standard Oil Company of California signed in 1944 and 1948, Naval Petroleum Reserve No. 1 was finally constituted as it is today.

Nearly 1,000 wells of the more than 1,235 wells drilled in NPR-1 to mid-1973 are producible from five oil and gas zones, which in descending order are as follows:

1. The Dry Gas Zone, the uppermost, consists of all dry-gas-bearing rocks above the top of the Lower Scalez marker bed. The Lower Scalez marker bed is a fossil horizon in the lower part of the San Joaquin Formation of Pliocene age. The reservoirs in this upper zone are thin very lenticular loosely cemented sandstones with relatively high permeabilities.

2. The Shallow Oil Zone includes all oil- and gas-bearing rocks of
Pliocene age above the Reef Ridge Shale, except the dry-gasbearing rocks above the top of the Scalez marker bed. The numerous reservoirs of this zone are thin lenticular highly permeable sandstones in the Etchegoin and lower San Joaquin Formations.

3. The Stevens Oil Zone contains all oil- and gas-bearing formations of late Miocene age within the stratigraphic interval between the top of the Reef Ridge Shale and the top of Valvulineria californica or associated faunas of middle Miocene age. The reservoirs in this zone are thick lenticular to tabular sheet sandstones and thick intervals of fractured siliceous shale in the upper part of the Elk Hills Shale Member of the Monterey shale. Both types of reservoirs have relatively low permeabilities.

4. The Carneros Oil Zone consists of one to three thick sandstones of Miocene age in the uppermost part of the Temblor Formation.

5. The Santos Oil Zone consists of a sequence of calcareous shale beds at the top of the Santos Shale Member of the Temblor Formation. The one well within the Naval Petroleum Reserve that produces oil from this zone is located within the Railroad Gap field.

Current production of NPR-1, largely the result of readiness testing, drainage prevention, and remedial work, is less than $1 \frac{1 / 2}{2}$ million barrels of oil a year. As of December 31, 1972, NPR-1 had produced $294,652,048$ barrels of oil. Ultimate recoverable reserves are estimated to be $1,302,010,335$ barrels of oil; thus 77 percent of the estimated recoverable oil is still in the ground.

Regional tectonic elements in central California are included in three major structural provinces-the Sierra Nevada, the Central Valley, and the Coast Ranges. These are elongate belts more than 400 miles long subparallel to the Pacific coastline. The Sierra Nevada, the easternmost province, is an immense block of granitic rock that has been faulted upward along its east edge and tilted gently to the west. The Coast Ranges, which compose the westernmost province, are an anticlinorium in which Mesozoic and Cenozoic sedimentary rocks are complexly folded and faulted. The southern part of this province is cut obliquely by the San Andreas fault. Between the Sierra Nevada and the Coast Ranges lies the tectonic trough known as the Central Valley of California, in which the Sacramento Valley constitutes the north half and the San Joaquin Valley the south half.

The Central Valley is an asymmetric basin with the axis near and parallel to its west border. The gently sloping eastern floor of the basin is a continuation of the Sierra Nevada granitic surface. The abrupt west flank of the basin has been complexly folded and faulted as a result of movement in the adjoining tectonically active Coast Ranges province and along the San Andreas fault. The San Joaquin Valley is divided by the Bakersfield arch, which appears to be alined with the Elk Hills anticlinal trend.

Tertiary and Quaternary deposits as much as 17,000 feet thick underlie Elk Hills and adjacent oil fields. The Temblor Formation, of Oligocene and Miocene age, is the oldest formation penetrated at Elk Hills; however, some wells in adjacent fields reached rocks of Eocene age, and one well in the North Coles Levee field stopped in metamor- 
phic basement rock. Most wells at Elk Hills are completed in reservoirs of late Miocene and Pliocene age. Rocks of Pliocene and Pleistocene age are exposed at the surface.

The Tulare Formation at the surface in Elk Hills has been folded into a large anticlinal structure consisting of two en echelon anticlines with broad tops and steep flanks referred to here as the Western and Eastern anticlines. The Western anticline trends southeastward and connects across a flat saddle to the less prominent Eastern anticline offset en echelon to the northeast. From its structurally highest point, the Western anticline plunges to the west-northwest about 660 feet and terminates in a very sharp nose. The axis of the Eastern anticline trends southeastward at its west end but curves eastward to slightly north of east and plunges into the San Joaquin Valley, where it terminates in a broad, blunt nose.

The subsurface structure at Elk Hills reflects the surface features, although the folds become sharper and more distinctly separable with depth. Two small anticlines mostly outside of NPR-1 lie parallel to the Western anticline near the west end of the reserve. One is the Railroad Gap anticline, and the other is the Flickinger anticline; both anticlines trapped oil in Miocene reservoirs. The broad subsurface nose extending eastward from the eastern Elk Hills anticline bifurcates and culminates in the two anticlines of the North and South Coles Levee fields. Few faults are found in the Miocene beds; numerous faults are present in the Pliocene beds of the Eastern anticline. Faulting does not appear to have had an appreciable effect on either the structural configuration or the trapping of petroleum at Elk Hills. Structural and thickness relations of subsurface horizons at Elk Hills indicate that the folds were growing in late Miocene time and have continued to do so to the present.

Several wells in adjacent oil fields have reached rocks older than those penetrated at Elk Hills. Metamorphic basement rocks of Jurassic(?) age were penetrated at a depth of 17,860 feet in the nearby North Coles Levee field. Several thousand feet of the Eocene Kreyenhagen Formation and the Oligocene Wagonwheel Formation were drilled in the Railroad Gap and North Coles Levee fields. The thick Point of Rocks Sandstone Member of the Kreyenhagen is an important potential oil reservoir.

The Temblor Formation, of Oligocene and early Miocene age at Elk Hills, is 2,900-4,100 feet thick and consists of the Santos Shale Member, the Carneros Sandstone Member (an important hydrocarbon reservoir), and the Media Shale Member. An unconformity separating the Temblor Formation from the overlying Monterey Shale, of middle and late Miocene age, has been postulated along the west side of the San Joaquin Valley.

The Monterey Shale has been completely penetrated by several tens of wells in Elk Hills and adjacent fields. It consists of about $2,100-4,100$ feet of diatomaceous or silty claystones, diatomites, siliceous shales, and sandstone lenses. The Monterey is divided into the Gould and Devilwater Shale Members, undifferentiated, the McDonald Shale of local usage, and the Elk Hills Shale Member. The last named member is divided in upward order into the $\mathrm{E}, \mathrm{DD}, \mathrm{D}, \mathrm{C}, \mathrm{B}$, $\mathrm{A}$, and $\mathrm{N}$ zones, several of which contain oil in fractured shale. In addition, the Elk Hills Shale Member encloses thick sandstone lenses that contain much of the oil reserves of the Elk Hills field.

The Reef Ridge Shale, the uppermost Miocene formation, reaches a maximum thickness of almost 1,150 feet in eastern Elk Hills. The contact between the Reef Ridge Shale and the overlying Etchegoin Formation, of Pliocene age, is marked by an unconformity in western Elk Hills.

Pliocene rocks underlying NPR-1 are divided into the Etchegoin and San Joaquin Formations. The Etchegoin, several thousand feet thick, consists of a lower silty shale unit and an upper sandy unit that contains considerable quantities of oil in multiple sands. The San Joaquin Formation consists mostly of shale interbedded with clayey siltstone and silty sandstone. Its thickness ranges from about 1,200 feet to nearly 2,100 feet across Elk Hills. The Scalez sand zone near the base of the formation is a prolific oil reservoir. Several relatively thin discontinous sands above contain dry gas. The interval from the base of the Etchegoin Formation upward though the Scalez zone of the San Joaquin Formation contains almost half of the oil reserves of Elk Hills.

Sandstone and conglomeratic beds of the Tulare Formation (Pliocene and Pleistocene) overlie the San Joaquin Formation. The thickness of the Tulare in the Elk Hills area ranges from 600 to 2,150 feet; about 700-850 feet of these beds is exposed on the surface. The Tulare Formation is overlapped by Quaternary alluvium along the perimeter of Elk Hills.

The sedimentary and fossil record at NPR-1 and the regional tectonic relations indicate that the area received marine sediments during late Eocene, Oligocene, Miocene, and most of Pliocene time. In late Pliocene and Pleistocene time, nonmarine conditions generally prevailed. The sea probably "was deepest in late Eocene time and gradually shoaled as deposition exceeded the rate of downwarping of the trough. Deep-water channel sandstones and turbidites were deposited in late middle Miocene time. As shallowing continued, the depositional environment changed from marine to alternating brackish and fresh water and finally to continental. Thickness and relative selfpotential maps indicate the probable development of a delta complex northeast of Elk Hills during middle and late Pliocene time.

Oil waș discovered at Elk Hills in 1919, and by 1929 more than 200 wells in eastern Elk Hills were producing from the Shallow Oil Zone. After Congressional authorization of development for wartime needs in 1944,317 more wells were drilled, most of them to the Shallow Oil Zone. Petroleum was found in the underlying Stevens Oil Zone in 1941. An exploratory program to delineate the productive limits of this zone along with the Shallow Oil Zone was started in 1945. After the exploratory program, 203 wells were drilled to the Stevens Oil Zone in the Navy's Readiness Development Program. The last largescale drilling occurred from 1951 to 1954 , when 178 wells, most of them directed to the Shallow Oil Zone, were drilled and completed. The discovery of the Asphalto field in 1963 and the Railroad Gap field in 1964 forced the Navy to drill more than 30 wells for reservoir evaluation purposes and to prevent drainage of oil from the Naval Petroleum Reserve.

The Santos Oil Zone of the Temblor Formation is the stratigraphically lowest reservoir presently productive at Elk Hills. Only one well is completed in this zone, and no porosity, permeability, or reserve figures are available.

The deepest production has been found in the Carneros Oil Zone, which overlies the Santos Oil Zone. Three relatively thick sandstones of low porosity and permeability produce oil and a considerable amount of gas and condensate. The estimate of original recoverable reserves of the Carneros Oil Zone in the Asphalto and Elk Hills fields is $5,270,000$ barrels of oil. :

About 250 wells have been completed in the Stevens Oil Zone. Petroleum reservoirs include the $\mathrm{D}, \mathrm{C}, \mathrm{B}, \mathrm{A}$, and $\mathrm{N}$ zones of the Elk Hills Shale Member and the $24 \mathrm{Z}$ and $26 \mathrm{R}$ sand bodies that transect the zones. The reservoirs in the zones are fractured shale and sandstone beds of different thickness and extent. Core analyses show an average porosity of 19 percent and an average permeability of 44 millidarcys. The $24 \mathrm{Z}$ and $26 \mathrm{R}$ sands are very thick reservoirs with an average porosity of 22 percent and an average permeability of 191 millidarcys. The estimate of original recoverable reserves in the Stevens Oil Zone beneath Asphalto and Elk Hills fields is 698,080,708 barrels of oil.

The Shallow Oil Zone includes reservoirs in the Tupman Shale and Carman Sandstone Members of the Etchegoin Formation and in the lowermost sandstones of the San Joaquin Formation. The reservoirs include thin sandstones, siltstones, and shales. Average porosities and permeabilities of the sandstone reservoirs increase upward; the highest. are. found in .the Scalez sand zone. Porosities and per- 
meabilities average 31 percent and 458 millidarcys, respectively. The Shallow Oil Zone has been produced more extensively than the other oil zones at Elk Hills, especially in the 1920's and during World War II. Cumulative production is $280,169,912$ barrels of oil, about 47 percent of the ultimate recovery estimate of $598,659,627$ barrels.

The Dry Gas Zone includes all dry-gas-bearing rocks above the top of the lowermost oil sands of the San Joaquin. At present, the reservoirs are mostly in the Mya sand zone, an alternating succession of lenticular sandstone and shale beds. Dry gas produced from the sands is mostly methane. Average porosity of the Mya sands is 36 percent, and the average permeability is 1,275 millidarcys. Production from the Mya sands has been 99,766,848 Mcf (thousand cubic feet) and the estimate of remaining recoverable reserves is 220,192,762 Mcf.

The existing 996 wells in NPR-1 are estimated to be capable of producing about 250,000 barrels of oil a day, but present surface equipment is inadequate to handle this amount of production. If full production were demanded, much additional surface equipment would be needed. A total of $294,652,048$ barrels of oil had been produced from NPR-1 by December 31, 1972. Most of the oil, 280,169,912 barrels, came from the Shallow Oil Zone. The largest remaining reserves of $683,988,638$ barrels of oil are contained in the Stevens Oil Zone. About 77 percent $(1,007,358,287$ barrels of oil) of the total original recoverable reserves at Elk Hills remain. New reserves will almost surely be developed with further exploration.

The source rocks for oil at Elk Hills are thought to be fine clastic sediments, rich in organic material, that were deposited by marine waters in the basins of the southern San Joaquin Valley from middle Eocene to middle Pliocene time. It seems likely that much petroleum came from the Tejon basin and the trough of the southern San Joaquin Valley basin and was trapped in the Elk Hills structure and other nearby traps in its general migration updip toward the west edge of the basin.

The Tulare Formation produces oil in the southwestern part of the San Joaquin Valley but has not been systematically evaluated at Elk Hills. A good oil show has been reported in at least one well, and electric logs indicate that oil may be present in several other wells. The Dry Gas Zone and the Shallow and Stevens Oil Zones have not been tested in large areas of the reserve, where both structural and stratigraphic traps may exist. Additional fractured-shale reservoirs may be found on small folds on the flanks of the Elk Hills anticline or on untested subsurface anticlinal structures. The very thick $24 \mathrm{Z}$ and $26 \mathrm{R}$ sands have not been traced completely across the reserve and could contain additional large oil reserves in favorable strüctural positions. Sand wedge-out traps along the flanks of the anticline are possible in both Pliocene and Miocene rocks. Carneros sandstone production can possibly be extended eastward; good oil shows have been found in these rocks near the middle of the Elk. Hills field. The sands appear to grade into shale in this direction, indicating the possibility of stratigraphic traps. The possibilities for additional production from below the Stevens Oil Zone are of major interest because such production has been found at both the west and east ends of NPR-1.

\section{INTRODUCTION}

\section{LOCATION OF STUDY AREA AND PURPOSE OF REPORT}

Naval Petroleum Reserve No. 1 (NPR-1) encompasses the Elk Hills oil field and small parts of the Railroad Gap, Asphalto, Buena Vista Hills, and North Coles Levee oil fields. These oil fields are located between the cities of Taft and Bakersfield in southwestern Kern County, Calif.

The Elk Hills oil field, which constitutes the largest part of Naval Petroleum Reserve No. 1, is about 20 miles southwest of the city of Bakersfield in the southern San Joaquin Valley of California (fig. 1). It extends over part of a large compound anticline, whose surface expression is a line of hills about 17 miles long and 7 miles wide (pl.1). Elk Hills field is classed among the giant petroleum fields of the world, which are limited to those with more than one billion barrels of recoverable oil (Burke and Gardnër, 1969, p. 49), or ten trillion cubic feet of gas (Halbouty, 1970, p. 5). The ultimate recoverable reserves of Elk Hills field are estimated to be in excess of 1.3 billion barrels of oil of which less than 300 million barrels have been produced. This estimate places Elk Hills as the 7th largest petroleum field in the United States, the 10th largest on the North American continent, and 83d in the world athis time, according to Halbouty (1970, table 1).

The United States Government owns about 80 percent, and the Standard Oil Company of California about 20 percent of the reserves within the Elk Hills oil field. Because of this divided ownership, Elk Hills oil field is operated as a unit under an agreement between the Office of Naval Petroleum and Oil Shale Reserves of the Department of the Navy and the Standard Oil Company of California. The unit operations are conducted by a unit operator selected on a bid basis for a 5-year period. Standard Oil Company of California has been the unit operator since the original agreement was negotiated in 1942.

This report summarizes the results of a 5-year investigation of NPR-1 (Elk Hills) made by the U.S. Geological Survey for the Office of Naval Petroleum and Oil Shale'Reserves, U:S. Navy. The results of the investigations 'were transmitted currently to the Navy in a series of 39 Technical Letters. This summary report includes many of the stratigraphic sections, structural diagrams, and structure maps previously transmitted as Technical Letters.

\section{PREVIOUS INVESTIGATIONS}

The geologic framework and history of the San Joaquin Valley have been summarized by Reed (1933), Reed and Hollister (1936), Hoots, Bear, and Kleinpell (1954), Repenning (1960), and Bandy and Arnal (1969). Regional correlations of Cenozoic rocks across the southern San Joaquin Valley from the San Andreas fault to the Sierra Nevada Foothills are shown on a correlation section published by the Pacific Section, American Association of Petroleum Geologists (Church and Krammes, 1957). Stratigraphic correlations between west-side oil fields of Kern County, including Elk Hills, are given on sections by Park and Land (1955). A comprehensive bibliography of the geological literature of the San Joaquin Valley is available from the Pacific Section of the American Association of Petroleum 
4

NAVAL PETROLEUM RESERVE NO. 1, ELK HILLS, CALIFORNIA

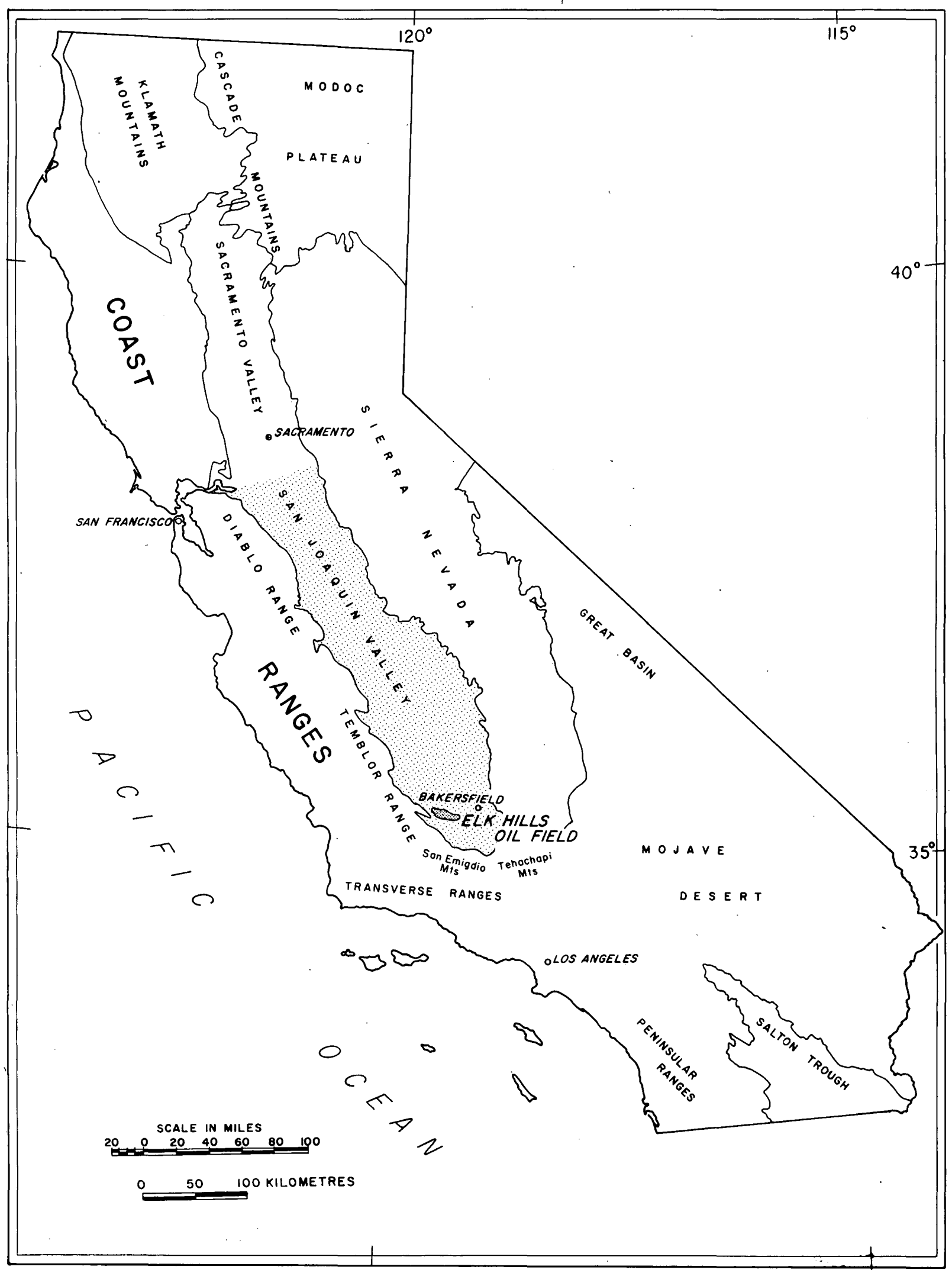

Figure 1. -Location of the Elk Hills oil field, San Joaquin Valley, Calif. 
Geologists, Los Angeles, Calif. (Maher and others, 1973).

Several early reports on the petroleum resources of California included discussions of the few oil fields developed in the southern San Joaquin Valley prior to the discovery of commercial quantities of petroleum at Elk Hills. Watts $(1894,1901)$ briefly described the oil- and gas- yielding formations in the McKittrick, Sunset, and Kern River oil fields. Eldridge (1903) discussèd more thoroughly the geology of these fields as well as that of the Coalinga field about 75 miles north of Elk Hills. Prutzman (1904) reviewed the drilling in these fields, and Cooper (1904) published analyses of crude oil from some of the wells. Anderson $(1905,1908)$ gave a brief discussion of the stratigraphy and paleontology of the region along the southwest side of the San Joaquin Valley.

The first published reference to the Elk Hills as a probable oil and gas field is that of Arnold and Johnson (1910), who completed a study of the region begun by Eldridge in 1901. They described 650 feet of the McKittrick Formation, now known as the Tulare Formation, exposed at Elk Hills, pointed out the close relation between structure and topography in the region, and recognized that the Elk Hills are made up of two nearly parallel folds of recent origin. In addition, they (p. 209) pointed out that "structural conditions in both the Elk and Buena Vista hills are practically ideal for the accumulation of petroleum. As the shales of the Monterey and Santa Margarita(?), which are believed to be the source of the oil throughout this region, underlie the McKittrick beds that form the surface of the hills, the chances for obtaining commercial quantities of petroleum in the district are excellent." As a result of the work of Arnold and Johnson, the public lands at Elk Hills were classified as oil lands, which were later withdrawn from all forms of entry by an Executive Order issued September 27, 1909 by President Taft.

In his report on the possible oil resources of the south end of the San Joaquin Valley, Anderson (1912) mentioned Elk Hills structure and stratigraphy and noted that the Elk Hills anticline projects a third of the distance across the valley. He concluded that until drilling to 5,000 or 6,000 feet became practicable, the greater part of the valley surface, beyond a strip a few miles wide along the border, was to be regarded as of extremely hypothetical value for oil. Anderson recognized that northward-flowing streams along the west side of the valley reflect the asymmetric shape of the syncline beneath the valley.

In 1914, McLaughlin and Waring (1914) listed the wells drilled in Elk Hills and nearby Buena Vista Valley and the mostly unsuccessful results of the drilling.
Later McLaughlin (1919) presented an engineering report on the development of natural gas at Elk Hills.

Pack (1920), in his paper on the Midway-Sunset oil field, described the structure of Elk Hills and concluded that the two surface anticlines unite at no great depth and form a single anticline. Wells had not been drilled through the Etchegoin Formation at that time. In addition, Pack listed the wells drilled in Elk Hills to that time and gave the drilling records for three successful oil wells drilled by the Associated Oil Company in 1911-12, about 7 years prior to the so-called discovery well, the Standard Oil Company (California) Hay No. 1. (See section "History of Naval Petroleum Reserve No. 1.")

Thoms and Smith (1922) published the first subsurface structure maps of parts of the field and a simple cross section of the eastern part. Collom (1921), Vander Leck (1921), and Wagner (1923) reviewed developments in the area. A large panoramic photograph of the Tupman area of Elk Hills in Vander Leck's report shows that relatively little development had taken place by 1921 (fig. 2).

In 1924, Hanna and Gaylord (1924) described and named the fossil Scalez petrolia in samples from wells at Buena Vista and Elk Hills oil fields. This fossil, which they regarded as a new genus and species of freshwater gastropods, marks an important stratigraphic horizon in what is now considered the lower part of the San Joaquin Formation. Woodring (1926) considered this fossil to be very similar to the operculum of Viviparus. Hanna (1926) agreed with this assignment and corrected locations and depths of samples given in his previous paper.

In 1925, the development in the east end of Elk Hills oil field was reviewed by Saunders (1925). He presented a structure contour map of the eastern part of the field and two cross sections of drillers logs. Ball (1926) reviewed the history of the Naval Oil Reserves before several meetings of the American Institute of Mining and Metallurgical Engineers during 1926. Woodring and Roundy (1927) published a short abstract on the geology of Elk Hills in which they mentioned that the structural closure increases with depth and reported subsurface faults of 250-foot displacement that could not be recognized at the surface. Roberts (1927) listed and discussed very briefly the fossil markers in wells at Elk Hills and adjacent fields, and Doyle (1927) discussed the development of Elk Hills into one of the richest oil and gas districts in California.

The first detailed account of the subsurface geology of Elk Hills oil field was published by Pemberton (1929). He pointed out that additional petroleum might be found in the Miocene rocks yet untested beneath the 


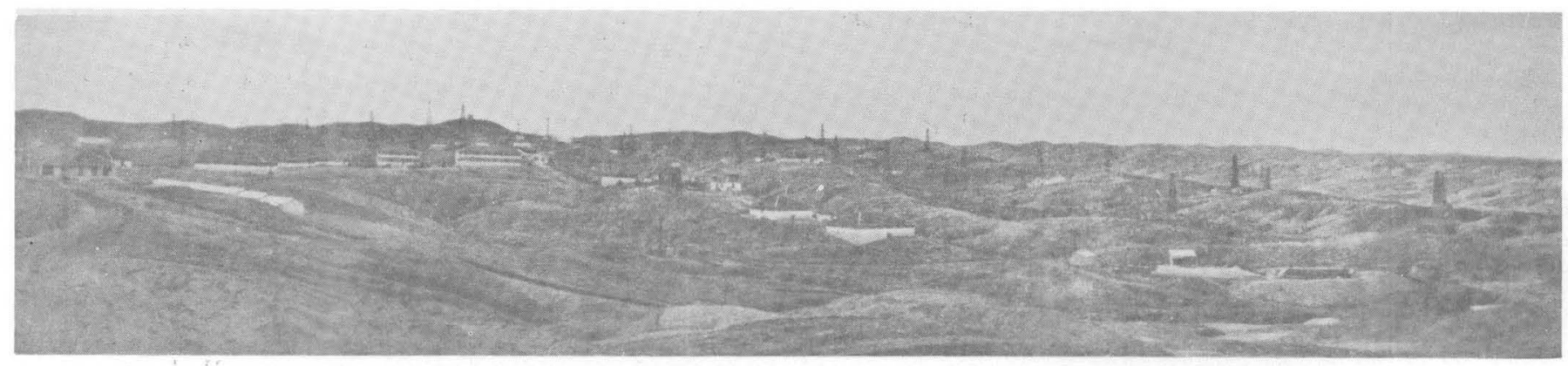

$A$

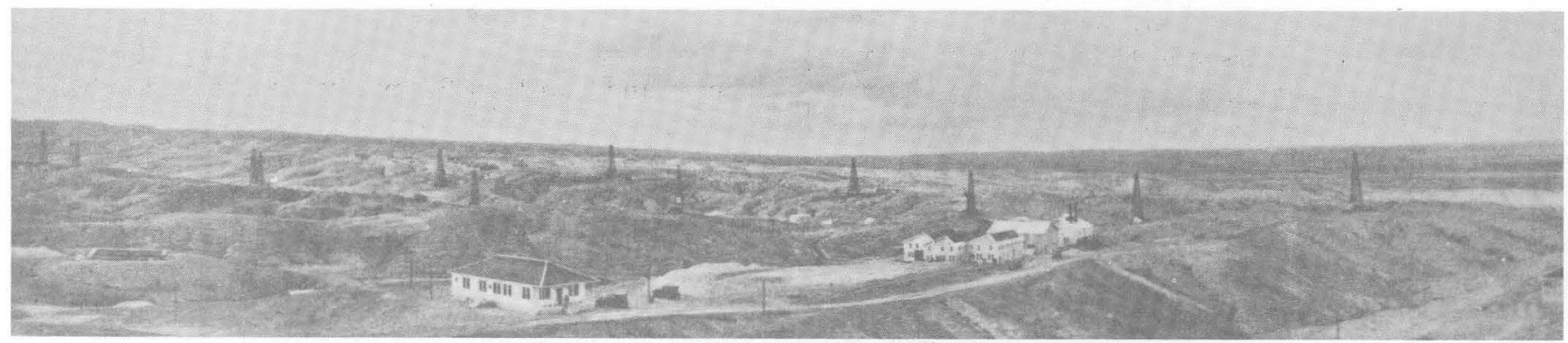

$B$

Figure 2.-Tupman Camp area, Elk Hills, about 1921. Building that served as USGS office during the period $1966-70$ in foreground of $B$. From Vander Leck (1921). View northwest.

field. Pemberton presented a west-to-east structure section across the field and a structure contour map of the shallow subsurface rocks that showed three faults in the eastern part of the field.

The most comprehensive geologic report on Elk Hills published to date is U.S. Geological Survey Bulletin 835 (Woodring and others, 1932), which included an areal geologic and surface structure map, shallow subsurface structure maps, structure sections, graphs of petroleum production, and maps showing the initial daily production, the gravity of initial oil, and the relation of waters to oil bodies. The geologic map, scale 1:31,680, with 25 -foot structure contours on a limestone in the upper part of the Tulare Formation is still the best available, but many of the other maps are obsolete because of the subsequent drilling of many hundreds of both shallow and deeper wells. This bulletin provided the starting point for most later investigations, and much from it has been used in the preparation of this report.

The Petroleum Times (1932) reviewed the development of the Elk Hills oil field, as did Hight (1933). Probably as a result of the business depression, not a single technical report about Elk Hills was published during the remainder of the decade.

The war years 1941-45 brought feverish drilling and production activity to Elk Hills, but aside from a few trade journal articles (Sanders, 1941; Stockman, 1942a, b, 1945a; Bunch, 1944; Frost, 1946) and news items (Oil and Gas Journal, 1944a, b, c, d, 1945, 1946a, b), only one technical report (Porter, 1943) was released before 1949.

A summation of exploration and development at Elk Hills during the war years and immediately thereafter was published by Eastman and Ruhlman (1949). This summary included structure maps of the Stevens Oil Zone (Miocene) and the Shallow Oil Zone and discussions of the exploration program and experimental programs on gas injection, water encroachment, and gravity drainage. One of the noteworthy findings in the exploration procedures was that electric logs are not diagnostic in predicting the fluid content or permeability of fractured-shale reservoirs in the Stevens Oil Zone. Drill-stem testing was found to be the most important yardstick in determining the productivity of these fractured-shale reservoirs.

In the early 1950's, reservoir and production problems were discussed in the Oil and Gas Journal (1953a), and the completion of the 1,000th well at Elk Hills was noted (Oil and Gas Journal, 1954a). Wells (1952) reviewed the Elk Hills field and included structure maps of both the Stevens and Shallow Zones. Regan (1953) referred to the San Joaquin Valley and Elk Hills in his paper on fractured-shale reservoirs in California. He stated that one of the principal features of the upper Miocene rocks along an east-west section across the valley is a change from sand and siltstone containing minor amounts of siliceous and cherty shale on the east to highly siliceous and cherty shales on the west. The 
most cherty rocks of the valley underlie Elk Hills and in the adjacent area to the west. He stated that the $24 \mathrm{Z}$ (Asphalto) and 26R sand bodies were deposited in upper Miocene depositional lows.

Gustafson (1953) reviewed the operations of Naval Petroleum Reserve No. 1. News items in the Oil and Gas Journal (1954b) and an article by Stormont (1954) discussed the unbalanced reservoir conditions at Elk Hills and the remedial operations. Gooch and Adams (1955) reported on the progress of operations from 1945 to 1954 as a supplement to the summary by Eastman and Ruhlman (1949).

Two detailed engineering reports were prepared by the Elk Hills Engineering Committee (1957a, b) revising the percentage participations and estimates of recoverable oil under the Unit Plan Contract, the unitization agreement between the U.S. Navy and the Standard Oil Company of California. These reports are very important from an economic standpoint because they define the oil zones and present thickness maps of the oil reservoirs showing the net productive sand. They are important also in a geologic sense because one (1957b) divides the Stevens Oil Zone into the N, A, B, C, D, DD, and PG intervals, which are used with some modification as stratigraphic zones in this report, and the other (1957a) groups the oil-producing Pliocene sands of the Shallow Oil Zone into units that also can be used as stratigraphic zones.

During the period from 1959 to 1967 , several engineering reports dealing with reservoir parameters and production problems at Elk Hills were prepared by personnel of the U.S. Bureau of Mines and the U.S. Navy. Caraway and Gates (1959) referred to core analyses and electric-log characteristics of a shallow oil sand there in their paper on methods for determining water content of oil-bearing formations. In a paper on relative permeability studies of gas-oil systems, Loomis and Crowell (1962) used some graphs of data from analysis of Elk Hills cores. Butterfield (1967) discussed the organization and administration of the petroleum and oil-shale reserves of the U.S. Navy and explained the different methods of maintaining a reserve of oil in the ground, including offset production, maintenance of pressure barriers, production of invading water, and gas injection. Baptist and Smith (1965) reported the results of laboratory research on the effect of gas saturation on the pressure gradient in SS-1 sand at the Elk Hills oil field.

Lorshbough (1967) published an article on the western part of Elk Hills oil field. It included two structure maps, one for Pliocene rocks, the other for Miocene rocks, and two structure sections, one of which shows the gas-oil-water contacts beneath the structure.

The discovery and development of the North and
South Coles Levee oil fields immediately east of Elk Hills were recorded in news articles in the Oil and Gas Journal (1941; 1943, 1944a, b, c, d, 1946b, 1953b). More detailed reports on the stratigraphy and structure were published by Taliaferro and Barbat (1946), LeConte (1948), Dosch (1962), and Hardoin (1962). Articles on pressure maintenance in the fields were released by Davis (1952), O'Neill (1952), and Sheldon and Sutton (1957).

The development of Railroad Gap oil field on the northwest edge of Elk Hills was discussed by Armstrong (1964a, b), Hardoin (1965), and Zeni and Cunningham (1967). The discovery of the Asphalto oil field on the southwest end of Elk Hills oil field was recorded in news items in the Oil and Gas Journal (1962, 1963a, b, c) and by Lawrence (1964). More detailed accounts of the geology were given by Anderson (1963) and Seiden (1965a, b), and in a guidebook of the Pacific Section, American Association of Petroleum Geologists (1968).

\section{PRESENT INVESTIGATIONS}

A comprehensive geologic study of NPR-1 was begun in 1966 by the U.S. Geological Survey at the request of the U.S. Navy, Office of Naval Petroleum and Oil Shale Reserves. A Geological Survey field office was maintained at Elk Hills for 4 years to handle the early phases of the investigations. These included geochemical investigations on crude oil, preparation of new base maps, processing of about 125,000 feet of core of which 60,000 feet was cut with a diamond saw and photographed, classifying and filing of well data and records, and numerous operational jobs such as advising on well locations and examining cuttings of drilling wells.

In 1969 a transfer of the staff from Elk Hills to the Geological Survey's research center in Menlo Park, Calif., began, and the field office was closed in May 1970. The next two years were devoted by a reduced staff to a systematic study of the subsurface stratigraphy and structure of the entire Elk Hills field and parts of the adjacent Railroad Gap, Asphalto, and North Coles Levee fields.

From time to time during the course of the investigations, the results were transmitted to the Navy in Technical Letters, which totaled 39 at the close of the study: From these results, some papers were released for publication. These include a comprehensive bibliography of geological literature on the San Joaquin Valley (Maher and Trollman, 1968; Maher and others, 1973), and a review of the Elk Hills oil field (Lantz, 1968). Connor and Gerrild (1971) published a paper on the geochemical differentiation of crude oil from six Pliocene sandstone units at Elk Hills. Maher, Carter, and Lantz (1972) analyzed the late Tertiary structural history of the Elk Hills anticlinal structure and pointed out the 
probability of a master fault subparallel to the top of the Reef Ridge Shale extending from the Eastern anticline eastward into the North Coles Levee oil field. In addition, two U.S. Geological Survey Bulletins describing and defining rock units in key wells at Elk Hills were published by Berryman (1973) and Adkison (1973). Some of the descriptions are incorporated in this report.

\section{LOCATION AND NUMBERING SYSTEM OF WELLS}

Nearly 1,000 wells of the more than 1,235 wells drilled in NPR-1 were producible in July 1973. Their locations and those of selected wells in adjacent oil fields are shown on plate 2 . The numbering and spacing of most conform to the standard California system (fig. 3). Townships in NPR-1 have been given letter designations by the unit operator-for example, T. 30 S., R. 23 $E$., is called " $R$ " township. All or parts of B, G, M, R, S, T, and $\mathrm{Z}$ townships are present within the boundaries of NPR-1 as shown on plate 2 . Letters identifying these townships are shown on other plates and figures where appropriate.

Well designations normally consist of two numbers separated by a dash-for example, well 363-25R. In

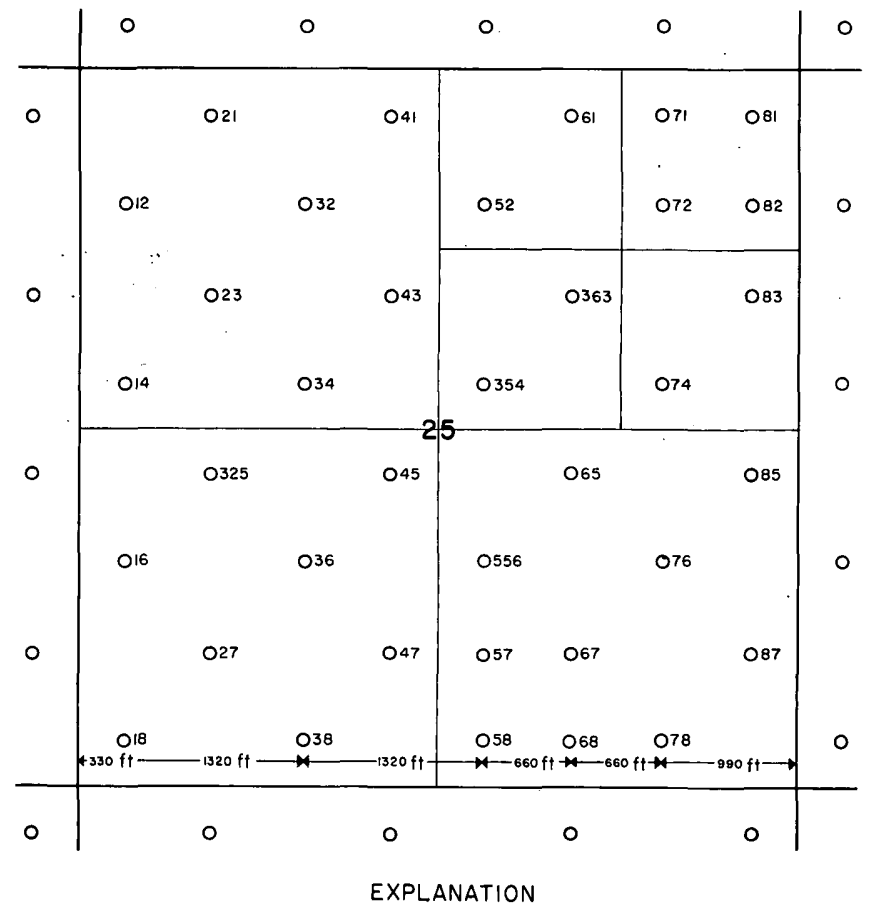

Wells drilled into rocks of Pliocene age (Shallow Oil Zone) are numbered $11-88$

Wells drilled into Monterey Shale (Stevens Oil Zone) ore numbered 311388

Wells drilled into Temblor Formation and underlying rocks are numbered $511-588$

The numbers for many early wells in the eastern part and a few late wells near the western limit of the field do not conform to this system.

FIGURE 3.-Well spacing and numbering system for Elk Hills oil field. figure 3 and on plate 2 the well is shown in the upper right quadrant of sec. 25 . The first digit (3) indicates the producing zone and the next two digits (63) indicate the location of the well within the section. The second number (25) means sec. 25 and the letter $(\mathrm{R})$ indicates the township according to the unit operator's map. Thus well 363-25R is a Stevens Oil Zone well located in the $\mathrm{NE}^{1 / 4} \mathrm{SW}^{1 / 4} \mathrm{NE}^{1 / 4}$ sec. 25, T. 30 S., R. 23E. Similarly, well $556-25 \mathrm{R}$ is located in the $\mathrm{SW}^{1 / 4} \mathrm{NW}^{1 / 4} \mathrm{SE}^{1 / 4}$ sec. 25 , T. 30 S., R. 23 E., and produces from the Carneros reservoir in the Temblor Formation. The first number of many wells consists of only two digits; such wells produce from the Shallow Oil Zone of Pliocene age.

\section{PUBLISHED BASE MAPS}

Base maps that show the topography of NPR-1 and adjacent areas have been published by the U.S. Geological Survey. These include the Bakersfield sheet (California Division of Mines and Geology, 1966) at a scale of $1: 250,000$ and the following $71 / 2$-minute quadrangles at a scale of 1:24,000: (1) Mouth of Kern, 1950, (2) Taft, 1950, (3) West Elk Hills, 1954, (4) East Elk Hills, 1954, and (5) Tupman, 1954. In addition, the U.S. Geological Survey prepared a special topographic map of NPR-1 at a scale of $1: 31,680$ in 1927 . This was used by Woodring, Roundy, and Farnsworth $(1932$, pl. 1) as a base for their geologic map.

Although planimetric maps showing well locations in NPR-1 are available from commercial map services, the only published well-location map for NPR-1 is that of the California Division of Oil and Gas (1968). This map shows the well numbers, as well as the locations, and is revised periodically.

\section{ACKNOWLEDGMENTS}

The Office of Naval Petroleum and Oil Shale Reserves, U.S. Navy, financed the investigations at Elk Hills from 1966 to 1970; subsequent work at Menlo Park was supported by the U.S. Geological Survey. The project was initiated by Captain K. C. Lovell, Director, Office of Naval Petroleum and Oil Shale Reserves and actively supported by his successors, Commander O. R. Butterfield, Captain H. N. Moore, and Captain E. C. Smith. Commander J. D. Denman was Officer-in-Charge at Elk Hills during the early years of the study. He was succeeded by Captain R. E. Sparks and Captain G. G. Dowd, $\mathrm{Jr}$. in that position. These officers and their engineering staff at Elk Hills, especially W. A. Walker, W. H. Burch, and $\mathrm{H}$. A. Klemme, and the unit operator, the Standard Oil Company of California, provided the open-handed cooperation so necessary to the success of the project. Numerous Survey scientists made significant contributions, some of which have been released as separate publications. W. L. Adkinson, E. E. Glick, W. M. Berry- 
man, J. S. Kelley, and W. A. McCracken studied the lithology of cores and samples, and R. S. Beck and James Burrow identified microfossils and made age assignments of the rocks. The writers obtained much of their background geologic information from many discussions with R. S. Beck, who pioneered in studies of the subsurface stratigraphy of the southern San Joaquin Valley. They are also indebted to T. W. Dibblee, Jr.; who conducted a special field trip for project workers to the outcrops along the west side of the San Joaquin Valley and provided much insight into the regional relations of the rocks. Uncredited photographs were supplied by E. W. Brubaker of the Standard Oil Company of California and William T. Rintoul, petroleum writer, Bakersfield. These are old photographs from newspapers and journals published during the early exploratory activity in the region or from private files, and the original photographer is unknown in most cases.

\section{GEOGRAPHY \\ AREA AND ACCESSIBILITY}

Naval Petroleum Reserve No. 1 consists of 46,095 acres, on which are nearly 1,000 oil wells ready for production (pl. 2). Most wells can be reached by oiled roads from about 50 miles of asphalt-paved roads within NPR-1. One of these asphalt-paved roads, known as Skyline Road (pl. 1) and maintained by the Navy, follows the crest of the Elk Hills from east to west. Another known as the Elk Hills Road, or Buttonwillow Road, and maintained by Kern County as County Road 261, crosses the middle of the reserve from north to south. State Highway 119 crosses the southeast corner of NPR-1 enroute from Taft to Bakersfield and has an interchange with Interstate Highway 5 about 5 miles east of the reserve boundary. Railroad and scheduledairline services are available in Bakersfield, a city of 67,955 people in 1970, 30 miles away by highway. The nearest commercial airport, suitable for light planes only, is about 15 miles southwest on the east side of Taft, a town of 4,235 people in 1970 .

\section{TOPOGRAPHY}

Naval Petroleum Reserve No. 1 encompasses the Elk Hills (pl.1; fig. 4), a foothill spur that extends from the Temblor Range southeastward about a third of the distance across the flat San Joaquin Valley. The juncture of the Elk Hills with the main foothills of the Temblors is marked by a prominent stream gap called Railroad Gap. The hills terminate eastward in low stream-cut bluffs along the Kern River where the river enters Buena Vista Lake, now dry except during unusually wet years. The village of Tupman, settled during the early drilling activity at Elk Hills, is situated on the flat valley floor near the northeast end of the hills.
A second foothill spur branches from the Temblors a few miles south and subparallel to Elk Hills. This line of hills, known as the Buena Vista Hills, is separated from Elk Hills by Buena Vista Valley and its northwestward extension, McKittrick Valley. Beyond the Buena Vista Hills to the south is Midway Valley in which Taft (formerly called Moron) and Fellows (formerly called Midway) are located.

The Elk Hills, named by Arnold and Johnson (1910, p. 20 ) for the Tule elk that ranged in them, are elliptical in outline and reach a maximum altitude of 1,551 feet, which is $1,000-1,200$ feet above the floor of the San Joaquin Valley (pl. 1; fig. 5). The shape and relief of this line of hills reflect the anticlinal structure of the underlying rocks. Rocks and soils in the Elk Hills are sparsely vegetated and easily eroded. A large number of ephemeral streams draining the hills have carved a strikingly intricate dendritic pattern of gullys and channels (fig. 6 ). The stream divides are numerous and narrow and have rounded crests, and the valley walls are generally smooth. The main stream divide is near the center of the line of hills in the eastern two-thirds of the reserve but swings to the south in the western one-third. Silt and sand eroded from the upper parts of the hills have been deposited along the base, and as a result, the hills merge gradually into the adjacent San Joaquin and Buena Vista Valleys. Slopes are steepest at the east and west ends of the hills because of erosion by the Kern River at an earlier time and by the ephemeral stream running through Railroad Gap.

\section{CLIMATE AND VEGETATION}

The climate at Naval Petroleum Reserve No. 1 is warm and semiarid. The nearest U.S. Weather Station is located at Bakersfield, about 20 miles to the east, where records have been kept since 1889 . The average rainfall at Bakersfield is 5.71 inches per year, but the rainfall at NPR-1, which is located in the rain shadow of the Temblor Range, is probably less. About 70 percent of the rain falls from December through March, and almost none from June through August. January is the wettest month; July and August are the driest months. The winter rains usually are gentle; torrential rains from summer thunderstorms are rare in the Elk Hills.

Average monthly temperatures at Bakersfield range from $47.2^{\circ} \mathrm{F}$ in January to $84^{\circ} \mathrm{F}$ in July (fig. 9). The range of the daily temperature is about $18^{\circ}$ in winter and about $30^{\circ}$ in summer. The average low temperature during the coldest month is about $38^{\circ}$, and the average high temperature during the hottest month is $99^{\circ}$. Temperatures at NPR-1 are about the same as Bakersfield.

Winters in the south end of the San Joaquin Valley are foggy. Downslope drainage of cold air from the surrounding mountains onto the floor of the valley creates 


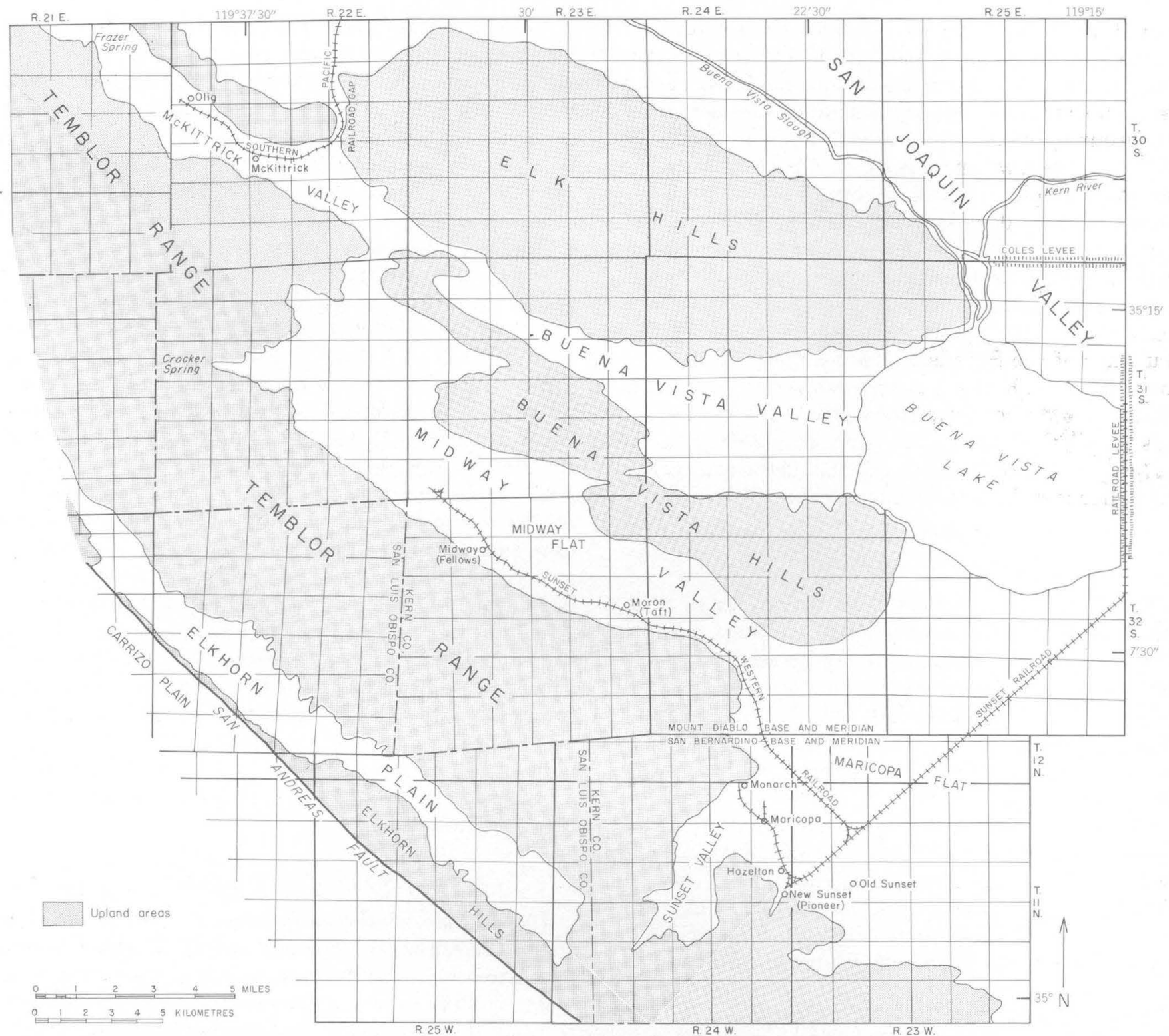

FIGURE 4.-Settlements, railroads and place names in southwestern San Joaquin Valley, 1908.

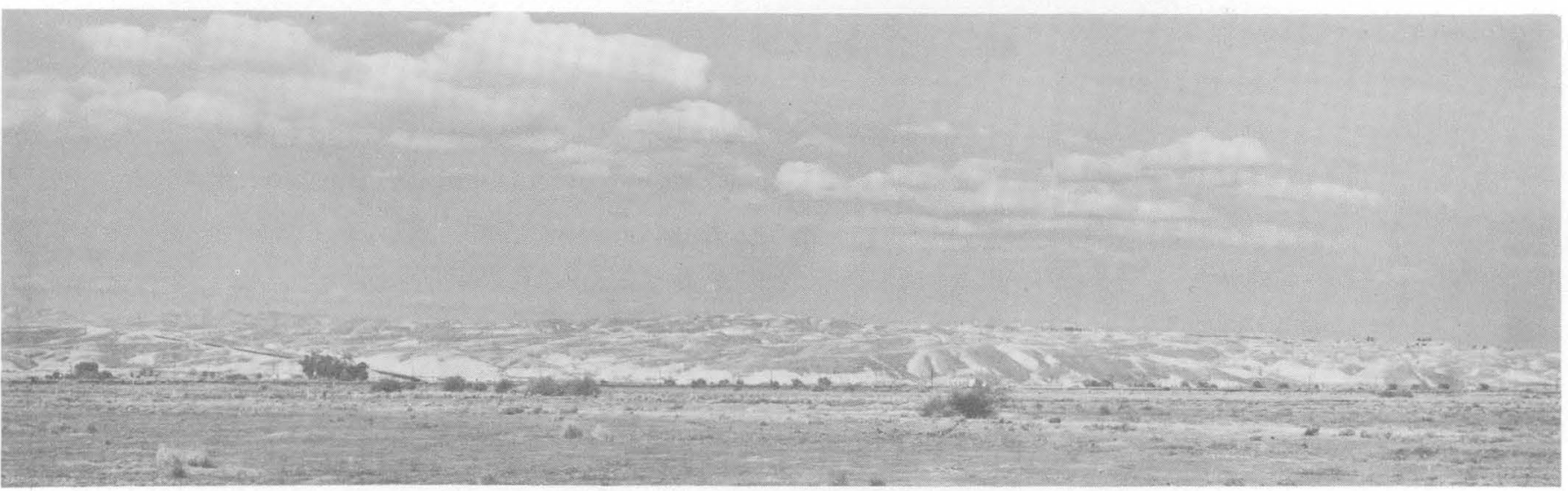

Figure 5.-Elk Hills as viewed from the North Coles Levee oil field. 


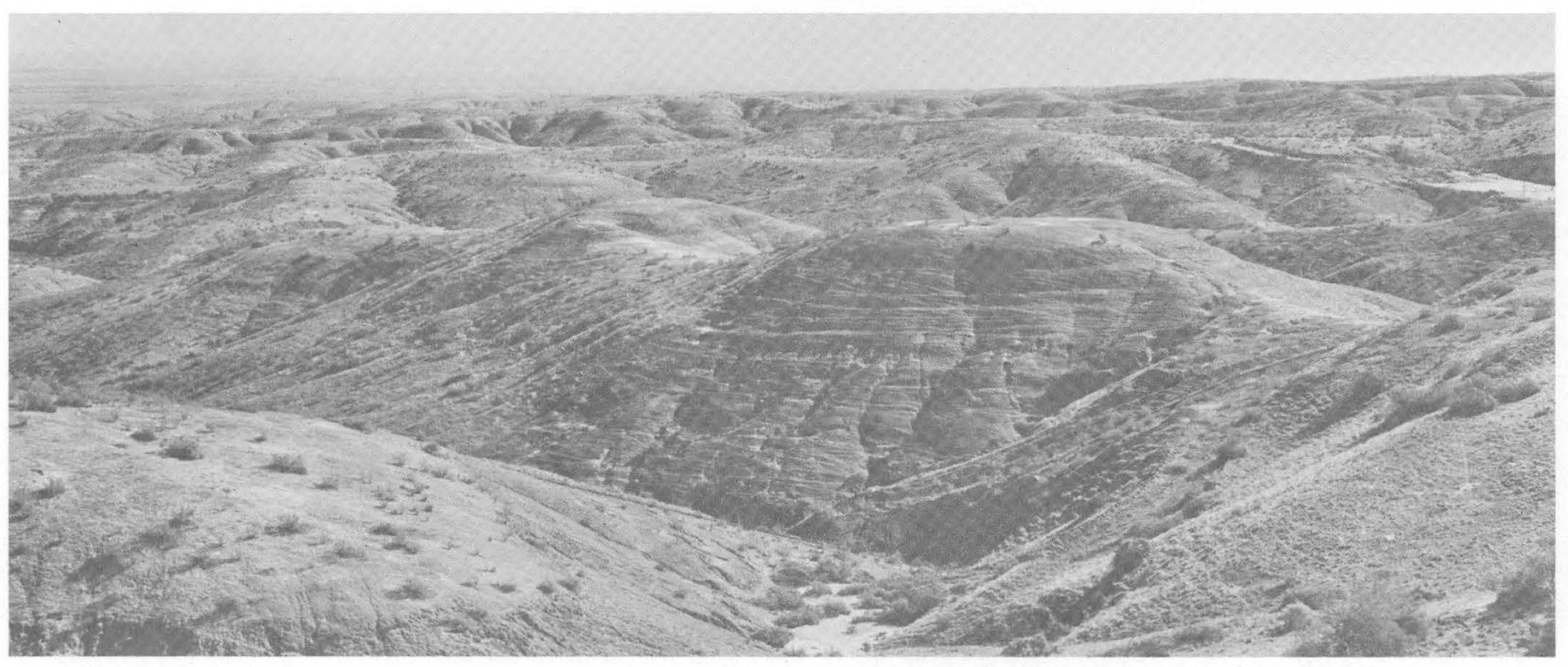

FIGURE 6.-Rounded divides and smooth slopes characterize the terrain of the Elk Hills.

fog that can last for more than a week at a time. The fog generally thins and lifts during the day only to thicken and settle at night. The fog prevents heat loss by radiation at night, so killing frosts are relatively rare. Summers are hot, dry, and comparatively cloudless.

The seasonal distribution of the small amount of rainfall has resulted in a sparse assemblage of plants adapted to rapid growth in winter and tolerance for drought. It is an area of winter annuals that grow rapidly, flower early, and mature quickly, traits that enable the plants to use the scant rainfall to best advantage. The most commonly seen wildflowers in the Elk Hills area are the sky lupine, California poppy, and the goldfields daisy. Common grasses are wild oats, sheep grass, red-stemmed filaree, foxtail, and red brome. The only widespread shrub is the common salt bush (Twisselmann, 1968, p. 11).

\section{WATER SUPPLY}

SURFACE WATER

The main streams are Buena Vista Creek, which flows intermittently from the Temblor Range southeastward between Buena Vista Hills and Elk Hills, and the Kern River, which flows occasionally after very high precipitation in the Sierra Nevada refills its former channels adjacent to eastern and northern Elk Hills.

Most intermittent eastward-flowing streams that head in the Temblor Range southwest of Elk Hills, such as Buena Vista Creek, do not carry potable water. These streams cross marine sedimentary rocks from which they acquire large amounts of dissolved solids. Analyses of waters from these streams show a minimum sulfate-ion $\left(\mathrm{SO}_{4}\right)$ concentration of 732 parts per million and a minimum of 1,300 parts per million total dissolved solids (Wood and Davis, 1959, p. 50; Wood and Dale, 1964, p. 89-90). Drinking-water standards issued by the U.S. Public Health Service state that water for domestic use should not contain more than 250 parts per million sulfate nor more than 1,000 parts per million total dissolved solids (Welsh and Thomas, 1960).

The Kern River is the southernmost of the major streams that rise in the Sierra Nevada and flow into the San Joaquin Valley. It flows westward out of the Sierra Nevada through a deep rocky gorge that terminates abruptly about 10 miles east of Bakersfield. The ancestral Kern River, which was at one time much larger than the present river, deposited a great alluvial fan from the Sierra foothills across the San Joaquin Valley to the Elk Hills (fig. 7). The alluvial fan interrupted and dammed the normal northward drainage of the south end of the valley. The impounded water formed Buena Vista and Kern Lakes (Davis and others, 1959, p. 30).

Before 1862, most of the runoff from the Kern River was carried by Old South Fork into Kern Lake and overflowed through the Connecting Slough into Buena Vista Lake (fig. 7). As a result of a large flood in 1862 , Old River became the main channel and remained so until the present Kern River channel was formed by the floods of 1867-68. Since that time the river has been controlled to remain in that channel, and most of the other distributary channels have been modified for use as irrigation canals. By 1891 most of the swampy and inundated land on the Kern River delta had been reclaimed for agricultural use, and irrigation canals had 


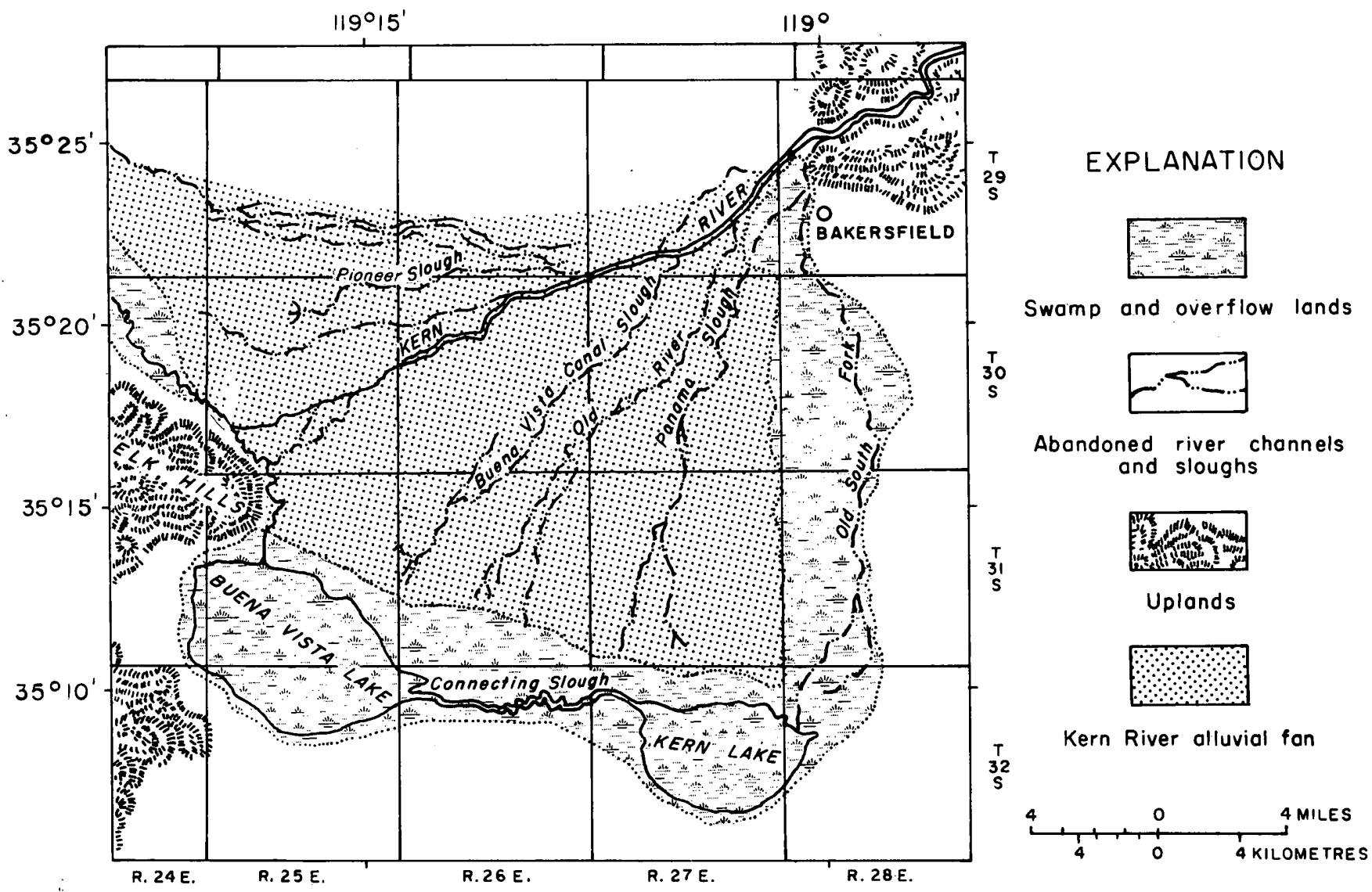

FIGURE 7.-Kern River alluvial fan and major historical channels of Kern River (adapted from Wood and Dale, 1964).

obscured the natural drainage pattern. Levees built along the east and north edges of Buena Vista Lake cônverted it into a storage reservoir. Additional dikes and levees confined the water to the northwestern part of the lake bed, and much of the drained lake bed was converted to farmland. In 1954 Isabella dam was constructed in the Sierra Nevada on the Kern River about 40 miles upstream from Bakersfield. The resulting reservoir made water storage at Buena Vista Lake largely unnecessary; since that time nearly all the Buena Vista Lake bed has been under cultivation.

The surface flow of the Kern River does not reach Elk Hills except in times of exceptionally high runoff and cannot be depended upon as a water supply. However, the water from the Kern River is of good quality because it flows over a terrane of predominantly igneous rocks and acquires only a small amount of dissolved solids in transit. Chemical analyses of 40 water samples taken from the Kern River near Bakersfield over a 6-year period (1950-56) showed that the dissolved-solids content ranged from 48 to 175 parts per million and averaged 95 parts per million during the period (Wood and Dale, 1964, p. 88).

\section{GROUND WATER}

More than 100 water wells have been drilled into the
Tulare Formation around the southeast, northeast, and north sides of Elk Hills. The records and locations of these wells taken from Wood and Davis (1959, tables 7, 8), and Dale, French, and Gordon (1966) are shown in table 1 and figure 8 . Chemical analyses of water from seven of these wells are given in table 2 . The system of well numbering used in these tables and in figure 8 indicates the locations of the water wells. For example, in the number $31 / 24 / 14 \mathrm{M}-1$, which was assigned to a well near the southeast boundary of NPR-1, the part of the number preceding the first slant indicates the township (T. 31 S.), the part between the slants shows the range (R. 24 E.), the part between the second slant and the dash indicates the section (sec. 14), and the letter following the section number indicates the 40 -acre division of the section as shown in figure 9. Within each 40-acre tract, water wells are numbered serially as indicated by the final digit of the number following the dash. Thus, well $31 / 24 / 14 \mathrm{M}-1$ is the first well to be listed in the NW1/4 SW $1 / 4$ sec. 14, T. 31 S., R. 24 E. As the entire Elk Hills area is in the southeast quadrant of the Mount Diablo base and meridian, the designation of townships south and ranges east is omitted. Wells given in tables 1 and 2 are identified by the entire number; however, wells in figure 8 are located in the proper section, town- 
TABLE 1.-Description of water wells in Elk Hills area [From Wood and Davis (1959) and Dale and others (1966)]

\begin{tabular}{|c|c|c|c|c|c|c|c|c|c|c|}
\hline Well & Owner or user & $\begin{array}{c}\text { Year } \\
\text { completed }\end{array}$ & $\begin{array}{c}\text { Altitude } \\
\text { of land } \\
\text { surface } \\
\text { (ft) }\end{array}$ & $\begin{array}{l}\text { Reported } \\
\text { depth } \\
\text { (it) }\end{array}$ & $\begin{array}{l}\text { Casing } \\
\text { diameter } \\
\text { (in.) }\end{array}$ & $\begin{array}{l}\frac{\text { Discharge }}{\text { Drawdown }} \\
\left(\frac{\text { (gal/min) }}{\mathrm{ft}}\right)\end{array}$ & $\begin{array}{l}\text { Depth to } \\
\text { water below } \\
\text { landsurface } \\
\text { (ft) }\end{array}$ & $\begin{array}{c}\text { Temperature } \\
\left({ }^{\circ} \mathrm{F}\right)\end{array}$ & $\begin{array}{l}\text { Specific } \\
\text { conductance } \\
\text { (micromhos } \\
\text { at } 25^{\circ} \mathrm{C} \text { ) }\end{array}$ & Use \\
\hline
\end{tabular}

T. 29 S., R. 23 E.

\begin{tabular}{|c|c|c|c|c|c|c|c|c|c|c|}
\hline $\begin{array}{l}25 \mathrm{~N}-1 \\
25 \mathrm{~N}-2\end{array}$ & Mirusol Ranch Co & $\begin{array}{l}1929 \\
1952\end{array}$ & $\begin{array}{l}275 \\
275\end{array}$ & $\begin{array}{l}219 \\
351\end{array}$ & $\begin{array}{r}18 \\
6\end{array}$ & $\cdots--$ & $\begin{array}{l}60 \\
65\end{array}$ & -. & 486 & $\begin{array}{l}\text { Irrigation. } \\
\text { Domestic. }\end{array}$ \\
\hline $27 Q-1$ & Gihilarducci Bros........... & 1935 & 269 & 238 & & & $\begin{array}{l}60 \\
39\end{array}$ & -- & 486 & $\begin{array}{l}\text { Domestic. } \\
\text { Irrigation. }\end{array}$ \\
\hline $34 A-1$ & Mirasol Ranch Co & 1934 & 270 & 238 & 16 & $\ldots$ & 51 & $\ldots$ & $\ldots$ & Do. \\
\hline $35 \mathrm{~F}-2$ & R. Garrison -..... & $\ldots$ & 275 & 218 & 8 & 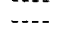 & 50 & - & ...- & Domestic. \\
\hline $35 \mathrm{C}-1$ & F Franceschi ...... & קבה"ה & 275 & 182 & 12 & $\cdots$ & 47 & -. & -..- & Domestic-irrigation. \\
\hline $36 \mathrm{C}-1$ & Mirasol Ranch ... & 1947 & 275 & 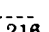 & 16 & $-\cdots$ & $-\overline{48}$ & -- & $\cdots$ & Irrigation. \\
\hline & 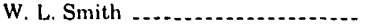 & & 277 & 218 & 14 & & & & $-\ldots$ & \\
\hline
\end{tabular}

T. 29 S., R. 24 E.

\begin{tabular}{|c|c|c|c|c|c|c|c|c|c|c|}
\hline $28 \mathrm{Q}-1$ & M. \& W. Snow , & 1935 & 280 & 322 & & $-\ldots$ & 70 & -. & -..- & Irrigation \\
\hline $28 Q-2$ & - & 1955 & 282 & 504 & 18 & --- & 85 & -- & $-\cdots$ & Do. \\
\hline $29 \mathrm{M}-1$ & Pierucci Bros & 1927 & 275 & .458 & 14 &.-- & -- & -. & 351 & Domestic. \\
\hline $30 \mathrm{P}-1$ & C. H. Craig & 1953 & 280 & 389 & 12 & $\ldots$ & 53 & .. & $\ldots$ & Irrigation. \\
\hline $\begin{array}{ll}30 \mathrm{Q}-1 \\
31 \mathrm{~F}-1\end{array}$ & Parsons Ranch & 1933 & 278 & 608 & & $-\cdots$ & 71 & -- & $---\cdot$ & $\begin{array}{l}\text { Domestic-irrigation. } \\
\text { Irrigation. }\end{array}$ \\
\hline $31 \mathrm{H}-1$ & Houchin-Bleeker Co & $\cdots$ & $\begin{array}{l}278 \\
280\end{array}$ & $\cdots$ & $\begin{array}{l}10 \\
--\end{array}$ & $\cdots$ & -- & $\overline{67}$ & 1,310 & $\begin{array}{l}\text { Do. } \\
\text { Do. }\end{array}$ \\
\hline $32 \mathrm{G}-1$ & Parsons Ranch ........................ & 1935 & 280 & 678 & - & $\ldots$ & 74 & -- & & Do. $\quad \therefore$ \\
\hline $32 \mathrm{M}-2$ & F. Franceschi & & 280 & & 16 & $-\cdots$ & 35 & -- & 800 & Domestic-irrigation. \\
\hline $32 \mathrm{M}-4$ & do & 1956 & 279 & 405 & 16 &.-- & 62 & .. & $-\ldots$ & Irrigation. \\
\hline $33 \mathrm{~A}-1$ & Houchin-Blecker Co &.-- & 283 & $-\ldots$ & 16 & & -- & -. & --- & Do. \\
\hline $\begin{array}{l}33 \mathrm{H}-1 \\
33 \mathrm{P}-1\end{array}$ & $\bar{M}, z_{\mathrm{W}} \mathrm{w}$. Snow & 1957 & $\begin{array}{l}280 \\
282\end{array}$ & $\begin{array}{l}351 \\
354\end{array}$ & $\begin{array}{r}18 \\
8\end{array}$ & $\frac{1,452}{30}$ & $\begin{array}{l}70 \\
55\end{array}$ & $\because-$ & -... & $\begin{array}{c}\text { Do. } \\
\text { Domestic. }\end{array}$ \\
\hline $\begin{array}{l}34 \mathrm{C}-1 \\
34 \mathrm{P}-1 \\
34 \mathrm{R}-1\end{array}$ & $\begin{array}{l}\text { R. Troutt } \\
\text { Vista Farms }\end{array}$ & $\begin{array}{l}1951 \\
1958\end{array}$ & $\begin{array}{l}285 \\
284 \\
285\end{array}$ & $\begin{array}{l}416 \\
377\end{array}$ & $\begin{array}{l}16 \\
14 \\
12\end{array}$ & $\frac{2,798}{58}$ & $\begin{array}{l}48 \\
62\end{array}$ & 70 & --. & $\begin{array}{l}\text { Irrigation. } \\
\text { Do. } \\
\text { Do. }\end{array}$ \\
\hline
\end{tabular}

T. 29S., R. 25E.

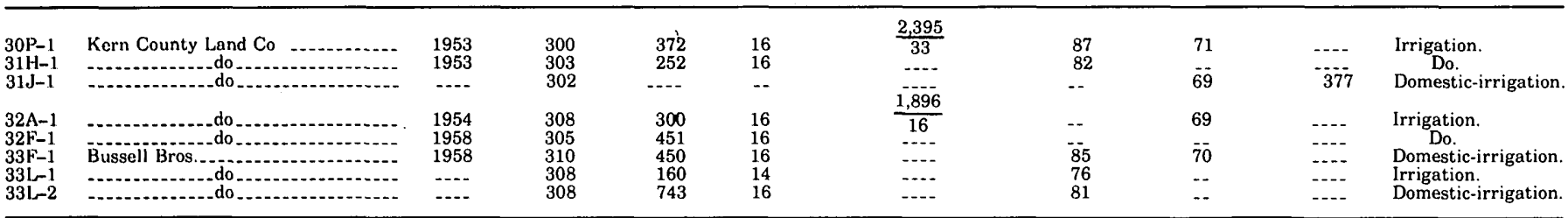

T. 30 S., R. 23 E.

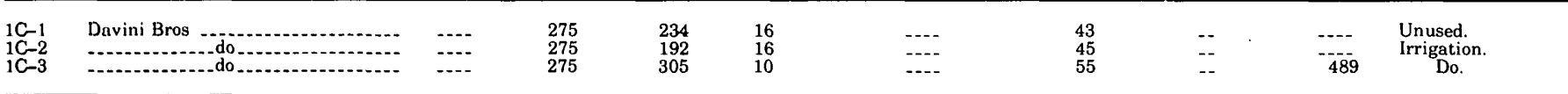

T. 30 S., R. 24 E.

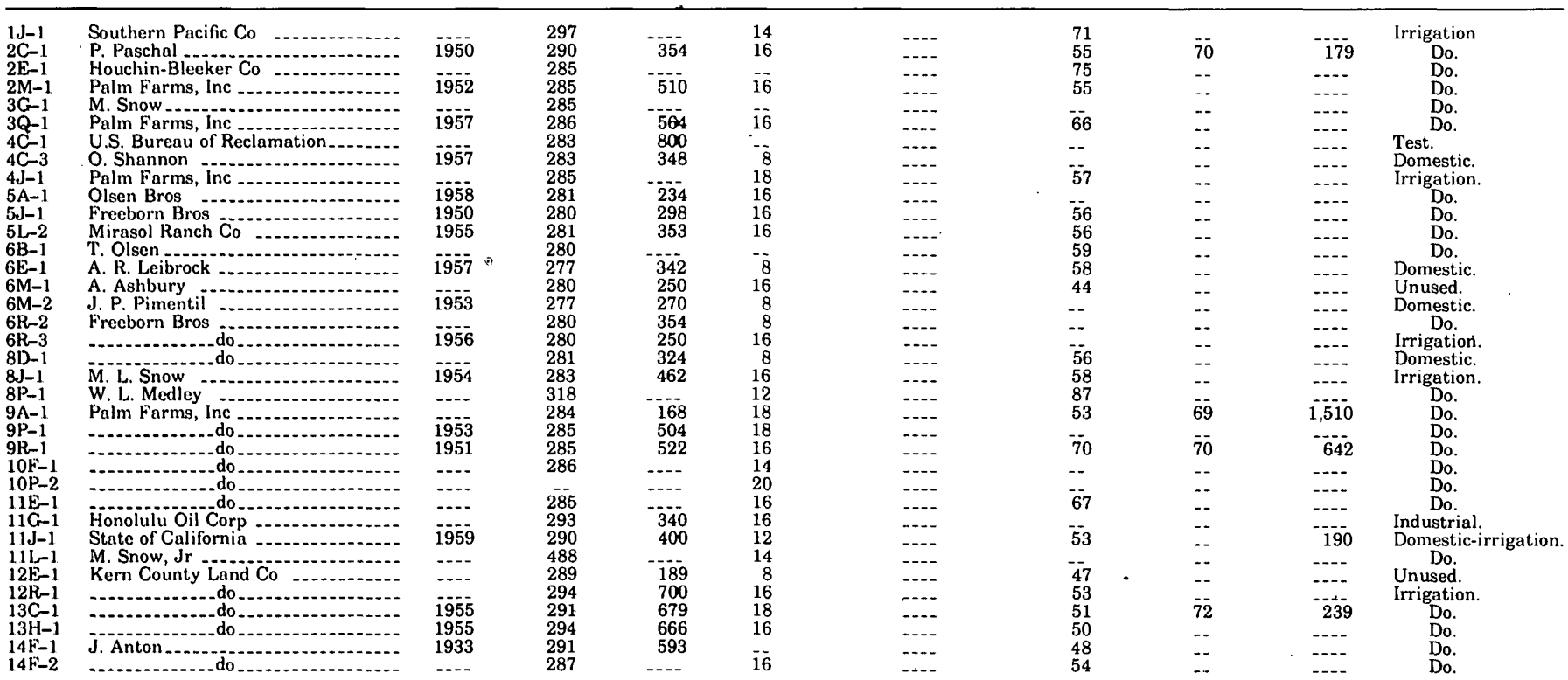


TABLE 1.-Description of water wells in Elk Hills area-Continued

\begin{tabular}{|c|c|c|c|c|c|c|c|c|c|c|c|}
\hline Well & Owner or user & 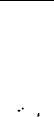 & $\begin{array}{c}\text { Year } \\
\text { completed }\end{array}$ & $\begin{array}{c}\text { Altitude } \\
\text { of land } \\
\text { surface } \\
\text { (ft) }\end{array}$ & $\begin{array}{l}\text { Reported } \\
\text { depth } \\
\text { (ft) }\end{array}$ & $\begin{array}{c}\text { Casing } \\
\text { diameter } \\
\text { (in.) }\end{array}$ & $\begin{array}{l}\frac{\text { Discharge }}{\text { Drawndown }} \\
\left(\frac{\text { (gal/min })}{\mathrm{ft}}\right)\end{array}$ & $\begin{array}{l}\text { Depth to } \\
\text { water below } \\
\text { landsurface } \\
\text { (ft) }\end{array}$ & $\underset{\left({ }^{\circ} \mathrm{F}\right)}{\text { Temperature }}$ & $\begin{array}{l}\text { Specific } \\
\text { conductance } \\
\text { (micromhos } \\
\text { at } 25^{\circ} \mathrm{C} \text { ) }\end{array}$ & $\begin{array}{r}\text { Use } \\
\quad:\end{array}$ \\
\hline
\end{tabular}

T. 30 S., R. 24 E.-Continued

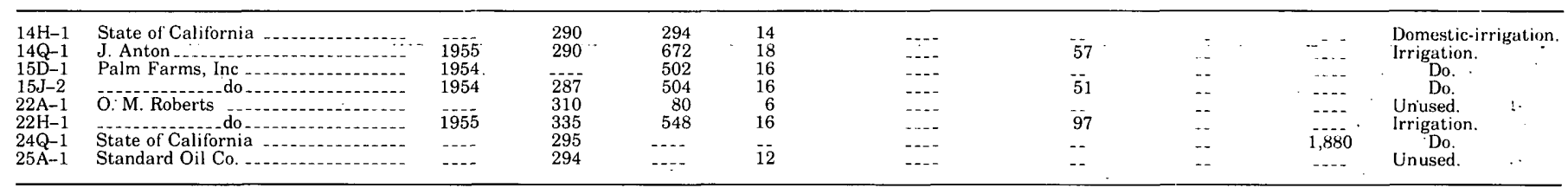

T. 30 S., R. 25 E.

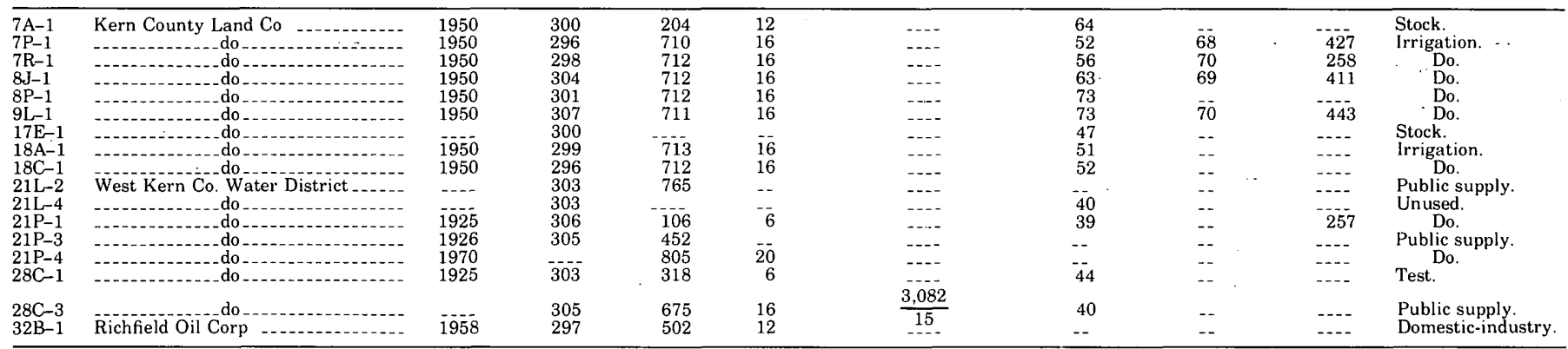

T. 31 S., R. 24 E.

\begin{tabular}{|c|c|c|c|c|c|c|c|c|c|c|c|}
\hline $\begin{array}{l}14 \mathrm{~F}-1 \\
14 \mathrm{M}-1 \\
21 \mathrm{P}-1 \\
22 \mathrm{~B}-1 \\
22 \mathrm{E}-1 \\
22 \mathrm{~F}-1 \\
22 \mathrm{H}-1 \\
22 \mathrm{~L}-1 \\
23 \mathrm{H}-1\end{array}$ & $\begin{array}{l}\text { H. Heimer } \\
\text { Small Bros } \\
\text { Riccomini \& Banducci } \\
\text { C. A. Sanders } \\
\text { D. L. Holland } \\
\text { L. V. Crowder } \\
\text { C. A. Sanders } \\
\text { McSwain \& Whitten - } \\
\text { State of California - }\end{array}$ & $\begin{array}{l}-\cdots \\
--. \\
-\cdots \\
--. \\
--. \\
1952 \\
1954 \\
1958\end{array}$ & $\begin{array}{l}390 \\
390 \\
410 \\
370 \\
388 \\
364 \\
345 \\
379 \\
302\end{array}$ & $\begin{array}{c}304 \\
--- \\
-500 \\
--- \\
---\overline{500} \\
347 \\
560\end{array}$ & $\begin{array}{l}10 \\
-- \\
1- \\
16 \\
12 \\
18 \\
16 \\
12 \\
--\end{array}$ & $\begin{array}{l}-\cdots- \\
-\cdots \\
-\cdots- \\
-\cdots- \\
-\cdots \\
-\cdots \\
-\cdots \\
-\cdots\end{array}$ & $\begin{array}{l}\ddots \\
.\end{array}$ & $\begin{array}{c}116 \\
127 \\
90 \\
-- \\
-- \\
82 \\
-- \\
--\end{array}$ & $\begin{array}{l}76 \\
74 \\
76 \\
-- \\
-- \\
7 \overline{74} \\
-.\end{array}$ & $\begin{array}{c}7,380 \\
-- \\
--- \\
-\cdots \\
-\cdots \\
6,020 \\
---\end{array}$ & $\begin{array}{l}\text { Unused. } \\
\text { Do. } \\
\text { Irrigation } \\
\text { Do. } \\
\text { Unused. } \\
\text { Do. } \\
\text { Irrigation. } \\
\text { Do. } \\
\text { Destroyed. }\end{array}$ \\
\hline
\end{tabular}

T. 31 S., R. 25 E.

\begin{tabular}{|c|c|c|c|c|c|c|c|c|c|c|}
\hline $\begin{array}{l}5 \mathrm{~A}-2 \\
5 \mathrm{~A}-3\end{array}$ & Western Water Co & $\begin{array}{l}1911 \\
1911\end{array}$ & $\begin{array}{l}300 \\
300\end{array}$ & $\begin{array}{l}571 \\
317\end{array}$ & $=$ & $\begin{array}{l}--- \\
-\cdots,- \\
1,935\end{array}$ & $\begin{array}{l}-- \\
--\end{array}$ & $\begin{array}{l}-- \\
--\end{array}$ & $--\cdot$ & $\begin{array}{c}\text { Destroyed } \\
\text { Do. }\end{array}$ \\
\hline $\begin{array}{l}16 \mathrm{D}-1 \\
16 \mathrm{E}-1 \\
16 \mathrm{H}-1\end{array}$ & $\begin{array}{l}\text { J. G. Boswell- }-10-10 \\
\text { do }\end{array}$ & $\begin{array}{l}1956 \\
1947 \\
1956\end{array}$ & $\begin{array}{l}298 \\
291 \\
297\end{array}$ & $\begin{array}{r}1,254 \\
500 \\
900\end{array}$ & $\begin{array}{l}20 \\
20\end{array}$ & $\frac{1,000}{28}$ & $\begin{array}{l}-- \\
--\end{array}$ & $\begin{array}{l}- \\
--\end{array}$ & $\begin{array}{l}2,350 \\
2,180\end{array}$ & $\begin{array}{l}\text { Irrigation. } \\
\text { Do. } \\
\text { Do. }\end{array}$ \\
\hline
\end{tabular}

ship, and range, and so only the letters and serial numbers are shown.

The water wells given in table 1 range from 6 to 20 inches in diameter and from 80 to 1,254 feet in depth. Most wells are 12-18 inches in diameter and 200-700 feet in depth and are used for irrigation. The water comes from sandstone and conglomerate of the Tulare Formation. The water levels stand from 35 to 127 feet below the land surface; most stand between 40 and 75 feet. Pumping tests of four of the large diameter (16-18 in.) wells produced discharges of 1,452 to 3,082 gallons per minute with drawdowns of $15-58$ feet. The specific capacities of these four wells range from 69 to 484 gallons per minute per foot of drawdown.

Ground water in the Tulare Formation beneath Elk Hills and Buena Vista Valley to the southwest is highly mineralized (table 2, wells 31/24/14M-1 and 31/24/22L -1 ), at least in part as a result of recharge by the highly mineralized waters flowing intermittently eastward from the Temblors. Ground water in the Tulare Formation around the southeast, northeast, and north sides of Elk Hills is soft and contains a small amount of dissolved solids (table 2 , well 30/25/21P-1). Recharge in this area is through the large alluvial fan built by the ancestral Kern River in Tulare time from the Sierra westward toward Elk Hills (fig. 7). The soft Kern River surface water from the igneous terrane of the Sierra percolates downward into the ancient alluvial fan before reaching Elk Hills but continues westward as underground flow that is intercepted by wells. The supply of ground water appears to be adequate for present uses, especially since additional irrigation water has become available from the California Aqueduct built in 1968 along the northeast edge of Elk Hills (pl. 1).

Communities and industries in an area of 240 square miles between Buena Vista Lake on the east, Maricopa on the south, and McKittrick on the north (fig. 4) are supplied water by the West Kern County Water Dis- 


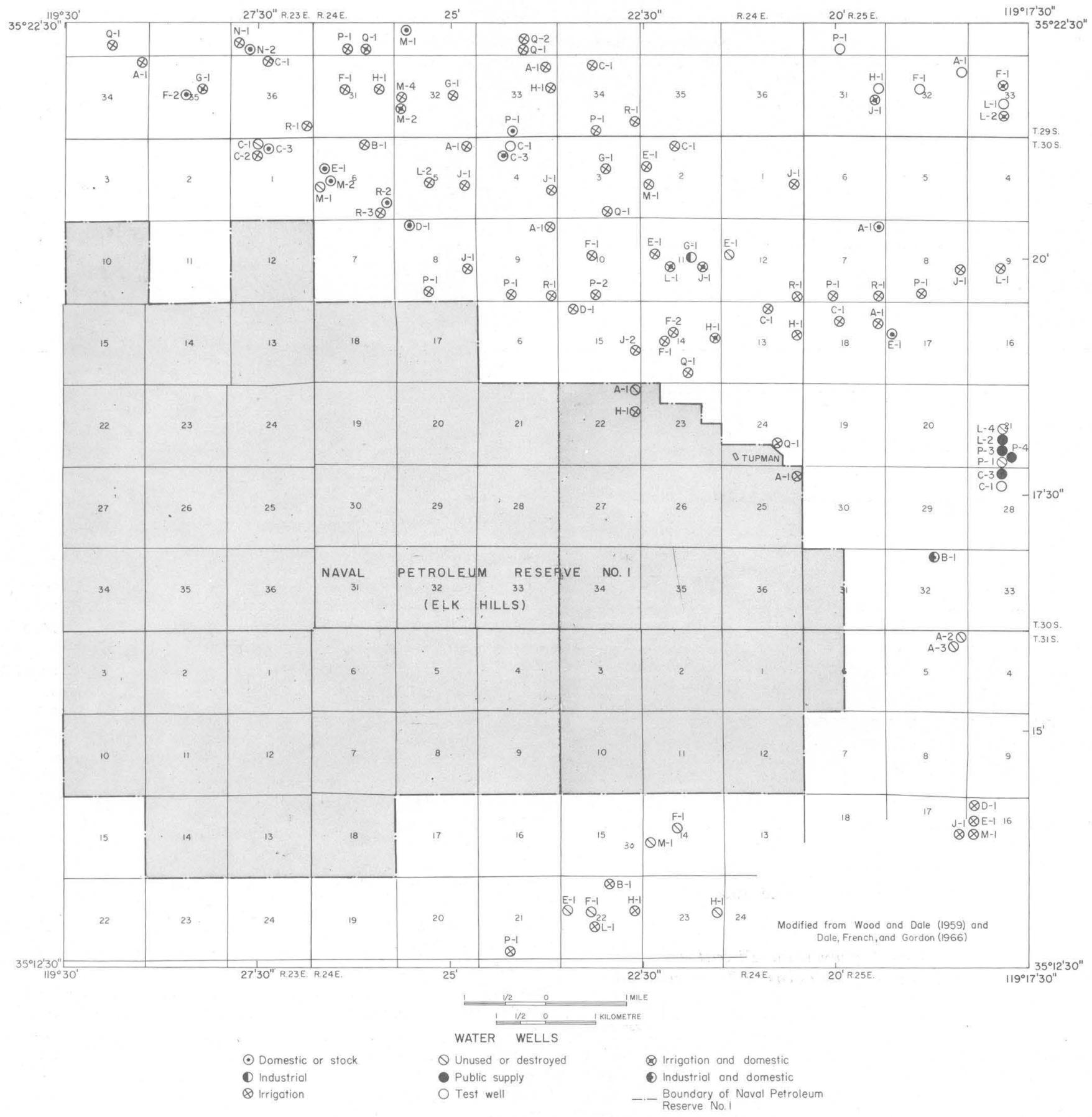

Figure 8.-Location and classification of water wells in Elk Hills area.

trict, successor to the privately owned Western Water Company. The district pumps about 8,100 acre-feet a year, or an average of approximately 7.2 million gallons a day, from four large wells about 4 miles east of Tupman in the old Kern River alluvial fan. Water from these wells is piped to Dustin Acres, Valley Acres, Taft, Ford City, Maricopa, Fellows, Derby Acres, and McKit- trick through 170 miles of mains that range from 4 to 30 inches in diameter. The storage capacity in tanks is 15 million gallons. The water is soft and is not treated or chlorinated. A drillers log of West Kern County Water District well 6-01 (well 30/25/21L-2, table 1) is given below to show the large amount of water-bearing sandstone and conglomerate in the Tulare Formation. 
TABLE 2.-Chemical analyses, in parts per million except as indicated, of waters from water wells in the Elk Hills area [From Wood and Davis (1959) and Dale and others (1966)]

\begin{tabular}{|c|c|c|c|c|c|c|c|c|c|c|c|c|c|c|c|c|}
\hline$\overline{\overline{0}}$ & 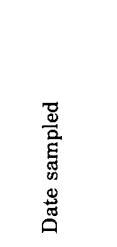 & 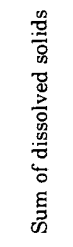 & 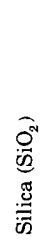 & 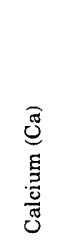 & 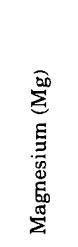 & 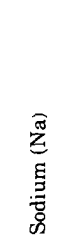 & 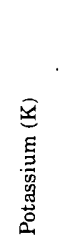 & 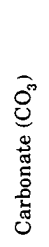 & 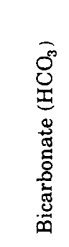 & 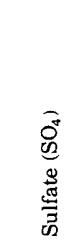 & 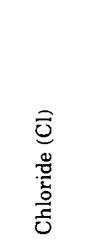 & 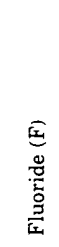 & 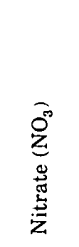 & 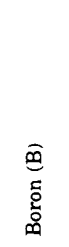 & 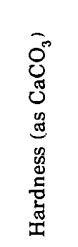 & . \\
\hline
\end{tabular}

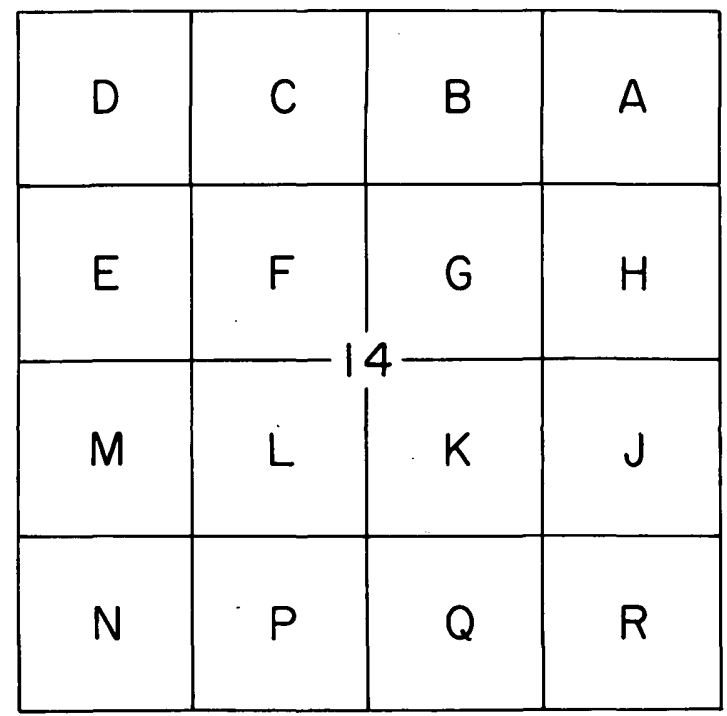

FIGURE 9.-System of numbering water wells according to location (Wood and Dale, 1964).

Drillers log for West Kern County Water District well 6-01 (well 30/25/21L-2 in table 1) about 4 miles east of Tupman, California:

$$
\text { Lithology }
$$

Top soil

Brown medium-size sand

Brown clay

Brown medium-size sand

Brown medium-size sand

Brown medium-coarse sand

Brown clay

Brown medium-size sand

Brown medium-size sand

Brown clay

Brown medium-size sand

Brown medium-size sand

Brown clay

Brown medium-size sand

Brown clay
Depth, in feet

$0-5$

5-8

8-12

$12-20$

20-30

$30-37$

37-47

47-52

52-98

98-118

118-123

123-125

125-127

127-129

129-142

142-146

146-157
Lithology-Continued

Depth, in feet

Gray medium-fine sand

157-167

Brown clay

$167-170$

Brown and gray medium-size sand _... 170-221

Brown clay _- 221-226

Gray medium-coarse sand

Brown clay _...... 235-274

Brown medium-size sand _._. 274-276

Brown clay - 276-283

Brown medium-size sand _..._._._. 2839

Brown clay _.

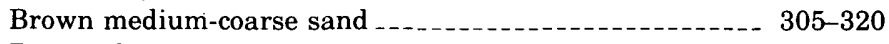

Brown clay _- 320-327

Brown coarse sand _. _. _ _ _ _

Brown coarse sand and gravel ........... 337-347

Brown clay _-_._- 347-351

Brown medium-size sand _...

Soft brown clay _._._.

Brown medium-size sand _._. _...

Brown clay -_._._._.

Brown medium-size sand _._...... 377-379

Brown clay _..._-_._._._. 379-387

Brown medium-size sand _...

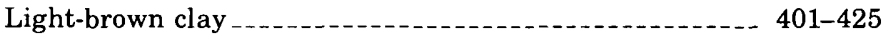

Medium-fine sand to silty sand

Soft brown clay _.

Brown medium-size sand _._.

Brown clay _.

Brown medium-size sand

Brown clay -

Light-brown medium-size sand _._.

Soft brown clay

Medium-coarse sand and small gravel _...

Brown clay - 523-544

Brown medium-coarse sand .

Gray clay _.

Brown coarse sand and small gravel _... . . . . . . . 564-590

Gray clay -... 590-606

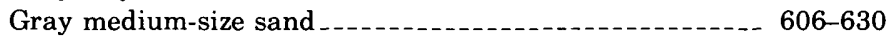

Sand and clay layers

Brown fine sand .

Brown coarse sand .

Brown clay -

Brown medium-coarse sand _.. 693-703

Light-brown clay _._.

Gravel and medium-size sand _... 708-711

Light-brown clay 


Lithology
Brown medium-coarse sand
Gray clay
Medium-size sand and gravel
Light-gray clay
Medium-coarse sand
Light-gray clay
Medium-size sand and small gravel
Blue and gray clay and sand
Total depth

HISTORY OF NAVAL PETROLEUM RESERVE NO. 1

\section{EARLY OPERATIONS IN THE SOUTHWESTERN SAN JOAQUIN VALLEY}

DEVELOPMENT OF SEEPS AND ASPHALT DEPOSITS

The earliest oil activity in the southwestern San Joaquin Valley was undertaken by the Buena Vista Petroleum Company in an area of extensive oil seeps northwest of the present village of McKittrick in the foothills of the Temblor Range (fig. 4). In the summer of 1864, the company dug pits and tunnels as much as 30 feet into the oil-saturated seeps. Oil with gravities from $10^{\circ}$ to $21^{\circ}$ seeped into the excavations and was bailed out in buckets. In 1866 the same company erected a 300gallon still near Frazer Spring, a few miles northwest of the seeps, and produced about 4,000 gallons of illuminating oil or kerosene. The operation was shut down primarily because of excessive freight costs (Watts, 1901, p. 125-126; White, 1962, p. 13).

Oil seeps in the McKittrick area continued to attract prospectors, however. In 1887 a well in which oil rose to within 3 feet of the top of the casing was completed at a depth of 565 feet. As a result of this discovery, the Buena Vista Petroleum Company built a three-kettle asphalt refinery, which used this oil as a flux in refining the local tar deposits. It was not long before this operation also was abandoned because of high freight costs.

Solomon Jewett and J. A. Blodgett of Bakersfield were instrumental in opening the southwestern San Joaquin Valley to oil production. The pair owned asphalt leases in the McKittrick area, where they had drilled a dry hole prior to 1887 , and in another area of extensive oil seeps about 25 miles to the southeast near the present village of Maricopa (fig. 4). In 1891 Jewett and Blodgett established an asphalt refinery at Old Sunset, a few miles southeast of Maricopa. Oil from 16 shallow wells was used to flux the asphalt; the total oil production was only 30 barrels per day (Pack, 1920, p. 64). The refined asphalt was hauled 40 miles to Bakersfield in freight wagons pulled by teams of 16-24 mules. The hitch of 24 mules was probably the longest in California operated on a single jerk line. The mule skinner had a caravan some 220 feet long, consisting of the 24 mules, three heavy freight wagons, a water tank, and a cart for emergency transportation (Rintoul, 1967a, p. 2). At Bakersfield the asphalt was transferred to railroad cars for shipment east.

In an effort to reduce transportation costs, Jewett and Blodgett came to an agreement with the Southern Pacific Railroad in 1892. The agreement provided for the formation of a jointly owned new firm, the Standard Asphalt Company, to which Jewett and Blodgett assigned their asphalt properties between Old Sunset and McKittrick in return for the construction of a branch railroad from Bakersfield to the McKittrick area. The branch railroad was completed through Railroad Gap at the west end of Elk Hills (fig. 4) in 1893.

The Standard Asphalt Company built a 12-kettle asphalt refinery at the west terminus of the railroad, which was appropriately named Asphalto. However, the operations could not show a profit even with the better transportation facilities, and the partnership was dissolved during the depression of 1893 . Jewett and Blodgett went back to their operation at Old Sunset near Maricopa (Pack, 1920, p. 63). The Southern Pacific retained the plant and properties at Asphalto and the name Standard Asphalt Company, which resumed asphalt operations after the depression of 1893 . When the refinery burned, another was built about $1 \frac{1}{2}$ miles southeast of the original location. The name Asphalto was transferred to the new refinery, and the old location was given the name McKittrick. A large amount of asphalt was processed by the Standard Asphalt Company until 1899 or 1900 , when operations ceased, and oil, not asphalt, became the primary product of the McKittrick area.

Jewett and Blodgett abandoned their old workings at Old Sunset in 1894 or 1895 and moved the refinery about 2 miles west to New Sunset, later called Pioneer (fig. 4). In August 1900, Jewett and Blodgett were producing 10-75 barrels of oil per day from 16 shallow wells at New Sunset. Oil production from the whole Maricopa area was commercially insignificant in 1900 (Watts, 1901, p. 123).

\section{DEVELOPMENT OF APPRECIABLE OIL PRODUCTION}

The Kern River oil field on the east side of the San Joaquin Valley near Bakersfield was discovered in the latter part of 1899. The development of the Kern River field was rapid because water was plentiful, transportation facilities were good, and the oil was found at shallow depths. More than 130 wells had been completed a little more than 1 year after the discovery, and by 1902 the Kern River oil field was yielding about two-thirds of all oil produced in California. The discovery of oil at Kern River and the existence of a railroad from Bakersfield to the McKittrick area spurred activity on the 
west side of the valley. According to Watts (1901, p. 126), 16 wells in the McKittrick oil field were producing oil, and 7 wells were being drilled in August 1900. Their productive capacity was estimated to exceed 1,200 barrels of oil per day. During 1900 the Santa Fe Railraod announced plans to lay a line from Bakersfield to Sunset, and this stimulated west-side activity even more. All public land open to filing in the foothills around Sunset was located, as far north as Midway (fig. 4). Several drilling rigs were moved in, and drilling commenced on some tracts. Most wells drilled in the Sunset area produced oil, but the oil could not be shipped until the railroad was completed in 1902 . By the time the railroad reached Sunset, the price of oil had dropped drastically and would fall even more. The drop in the price of oil was more disastrous to the bold wildcatters drilling around Midway than to the operators at Sunset near the railroad because lumber, machinery, fuel, drinking water, and even drilling water for the Midway wells had to be hauled by team from McKittrick or Sunset. Water cost $\$ 1.25$ per barrel delivered at the well. Pack (1920, p. 65) reported that after the water was delivered, the drillers had to allow the 10-mule teams used to haul the water to drink from it, and the mules would sometimes drink nearly half. Fuel delivered to the drilling rigs cost $\$ 2.90$ per barrel, while oil from the Kern River oil field, only 40 miles away, was selling for 8-10 cents per barrel.

The depressed price of oil retarded the development of the oil fields in the southwestern San Joaquin Valley until 1907, when the price of oil rose to about 50 cents a barrel. The improved price of oil resulted in accelerated activity in both the Sunset and Midway areas, and a pipeline was laid from Midway to the railhead at Sunset. The period of most active development did not take place until 1909, however, when the railroad was extended from Sunset to Midway. The Midway-Sunset field produced less than 50,000 barrels of oil a month prior to 1909 , about 400,000 barrels a month by the end of 1909 , and $3,200,000$ barrels a month by the end of 1913 (McLaughlin and Waring, 1914, p. 223-224). Figure 10 is an aerial view of the Midway-Sunset oil field showing the development about 1940 .

\section{GUSHERS OF THE MIDWAY-SUNSET FIELD}

Many spectacular wells were drilled in the MidwaySunset field. In November 1909, Chanslor-Canfield Midway Oil Company brought in the first big well in the field, the Midway Gusher. This well, located near the present village of Fellows, flowed 2,000 barrels of oil per day. Buring the following year, more than 25 such gushers were drilled; some of which caught fire and burned for days (fig. 11). The most famous of all gushers in the Midway-Sunset oil field was the spectacular
Lakeview Gusher (fig. 12) in sec. 25, T. 12 N., R. 24 W. It blew in March 14, 1910, and the following day produced 18,000 barrels of oil. Within a few days the flow had destroyed the derrick, and the sand carried with the oil had buried the engine house. The Lakeview Gusher produced oil at a maximum rate estimated to be $65,000-90,000$ barrels a day. Oil spray drifted for miles, the roar of the wildly flowing oil and gas could be heard throughout the field, and the plume of oil could be seen 30 miles away. Earthen sumps were made by hastily throwing dams across the small gullies in the area, and later 20 huge earthen reservoirs were built. These reservoirs covered an area of 60 acres, and held more than 5 million barrels of oil on September 15, 1910 (Rintoul, 1967b). On September 9, 1911, 544 days after the well blew in, the Lakeview Gusher bridged over and died. The well had produced between 8 and 9 million barrels of oil, of which 5-6 million barrels had been saved. The price of Midway-Sunset oil dropped to 10 cents a barrel (Pack, 1920, p. 65-66; Rintoul, 1967a, p. 3-4).

The Lakeview Gusher generated feverish excitement-39 new oil companies were formed within two weeks. At Siding No. 2 of the Sunset Railroad, a cluster of buildings called Moron grew into a community that was later named Taft. The Sunset Railroad sent trains with as many as 28 tank cars of water to the parched populace of the oil towns. The water sold for as much as 50 cents a barrel; the returning trains hauled away long strings of tank cars filled with oil that sold for considerably less than the water.

\section{DRILLING IN THE BUENA VISTA HILLS}

During the period of feverish activity and wild speculation set off by the gushers, the bolder wildcatters left the foothills of the Temblor Range and began drilling in Midway Valley and in the Buena Vista Hills (fig. 4). The Buena Vista Hills obviously were formed by an anticlinal structure, and the wildcatters gambled that the hills were underlain by oil-bearing rocks. In 1909, a well drilled by the Honolulu Consolidated Oil Company in Buena Vista Hills hit a strong flow of gas at a depth of about 1,600 feet and blew wild for two months before it was brought under control. Drilling was continued to a depth of about 2,500 feet, where the well was completed early in 1910, flowing between 2,000 and 3,000 barrels of oil a day. By the end of 1910 both Honolulu Consolidated Oil Company and Standard Oil Company (California) had several oil wells completed in Buena Vista Hills. Meanwhile wildcatting had spread to an even larger anticline reflected by the Elk Hills less than 3 miles to the north.

Figures 13 and 14 show relics of wooden cable-tool rigs used to drill in Buena Vista and McKittrick fields about 1910. Figure 15 shows a steel derrick still stand- 


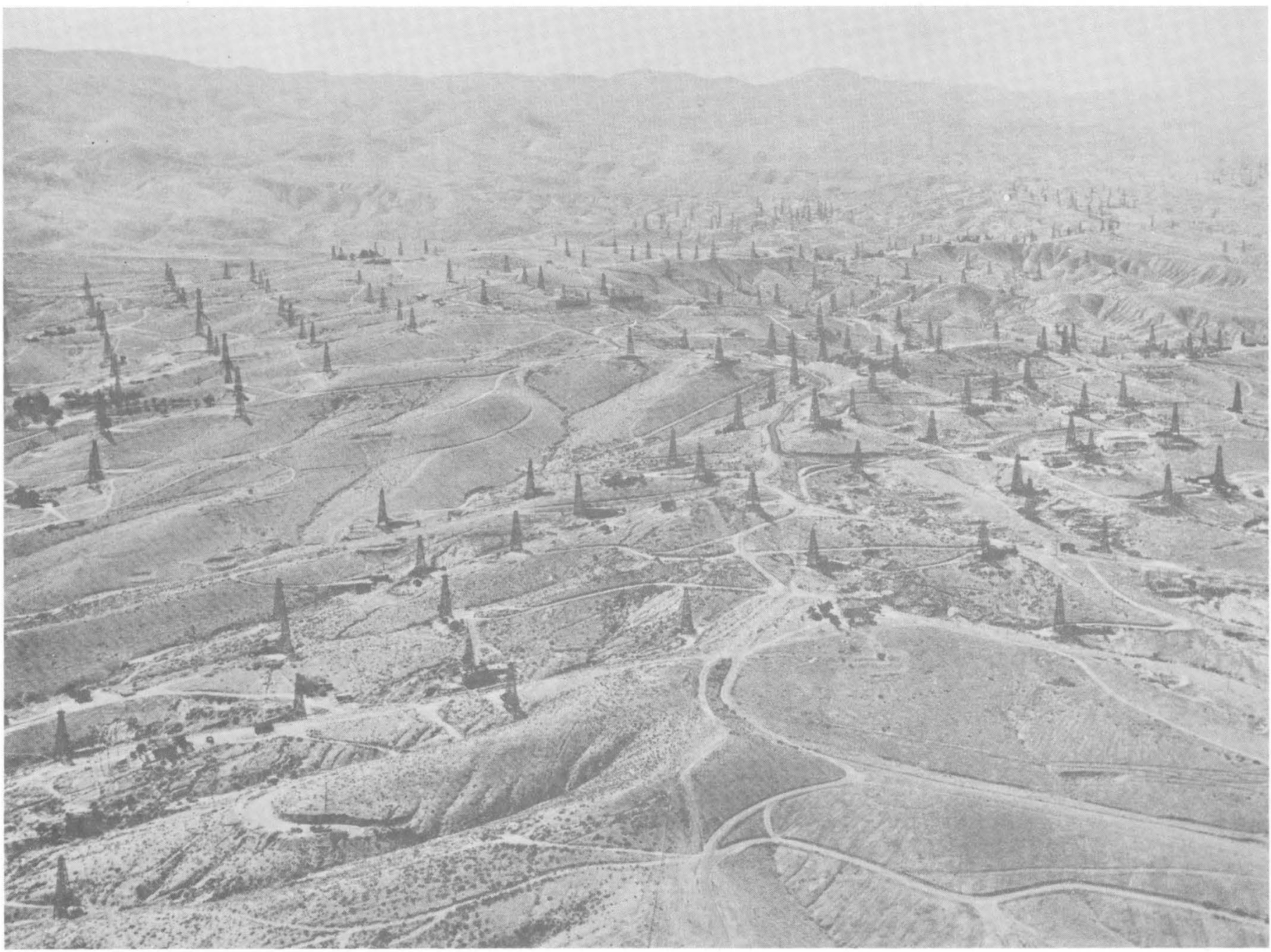

Figure 10.-Midway-Sunset field as seen from the air about 1940.

ing in Buena Vista field. These, which were used with either cable-tool or rotary drilling equipment, gradually replaced the wooden derricks after 1925.

\section{DISCOVERY OF OIL AT ELK HILLS}

The Associated Oil Company, incorporated October 7 , 1901, was formed by independent oil producers in the Kern River field. This combine hoped to control enough production to enter into large sales agreements with refiners and marketers at better prices than the 20 cents or less a barrel offered in the spring of 1901. The Southern Pacific Railroad, seeking a secure supply of locomotive fuel, acquired a large stock interest in the Associated Oil Company in 1903 and took control in February 1910. In March 1910, the Associated Oil Company acquired leases in Elk Hills (secs. 22, 24, 26, T. 30 S., R. 23 E., and sec. 30 , T. 30 S., R. 24 E., fig. 16) from the holders of some long-dormant mining claims.

During 1910, more than 20 wells were started in Elk
Hills, and several others followed in 1911 (Woodring and others, 1932, p. 47) despite the fact that all public lands there had been withdrawn from all forms of entry on September 27, 1909. The only successful wells were three drilled by the Associated Oil Company, the subsidiary of the Southern Pacific Railroad (fig. 16). The first of these was located in sec. 26 , T. 30 S., R. 23 E., and was completed on June 16,1911 , with an initial production of 75 barrels of oil per day from what is now called the Shallow Oil Zone. This marked the discovery of petroleum in Elk Hills, although a much later well, Standard Oil Company (California) No. 1 Hay, drilled in 1919, is generally treated as the discovery well. The United States Government had filed suit against the Southern Pacific Railroad in December 1910 to recover about 6,000 acres in Elk Hills. While this was in litigation, the Associated Oil Company, a subsidiary of Southern Pacific, was actively drilling for oil on leases offsetting some of this land. The railroad's legal position 


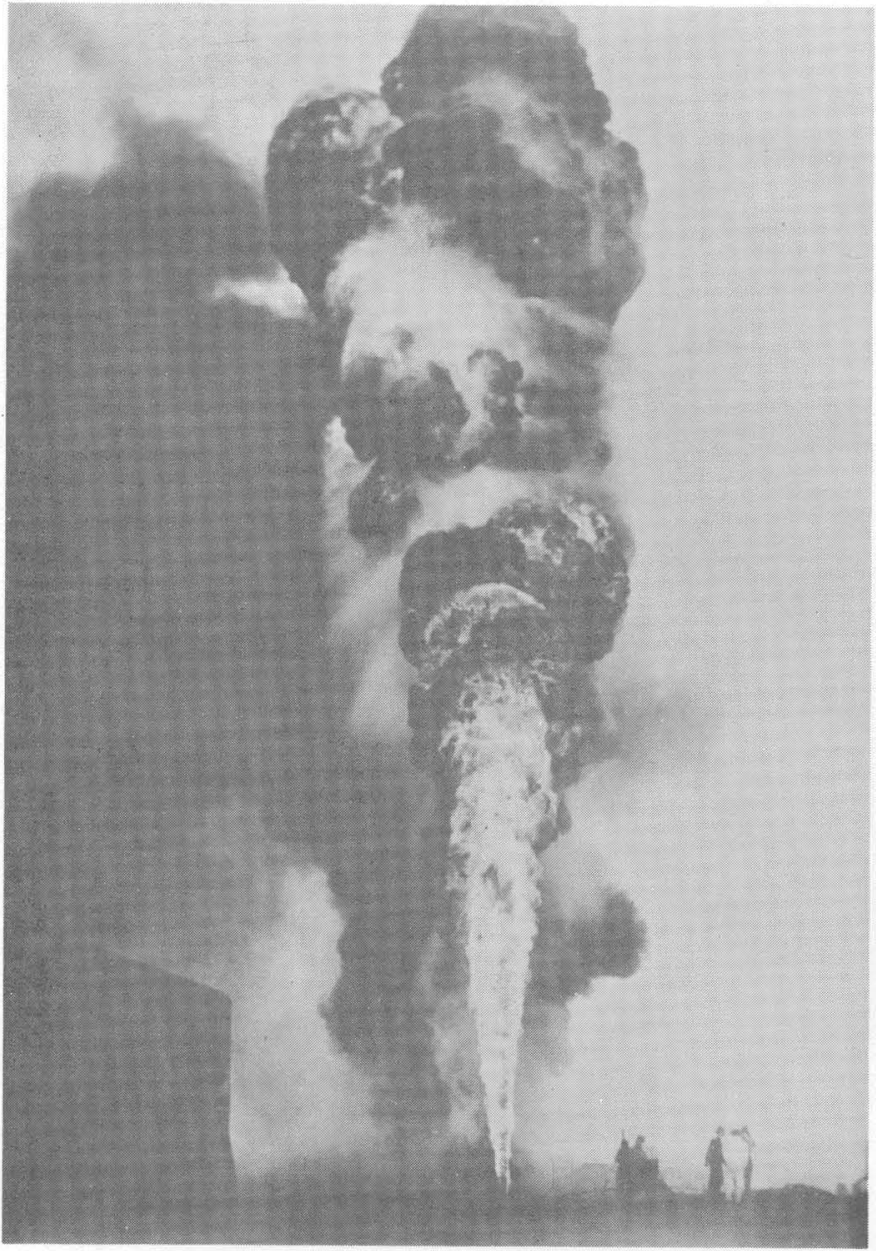

Figure 11.-Burning gusher in the Midway-Sunset field about 1910.

in the lawsuit was weakened by these activities, and as a result, the subsidiary did not seriously press its claim for patent on the productive leases nor did they perform additional development or exploration (Ragland, 1944, p. 118).

\section{WITHDRAWAL OF PUBLIC OIL LANDS}

\section{CONSERVATION MOVEMENT}

Conservation became an active political issue in the first two decades of the 1900's and was an important part of the philosophy of the Progressive political movement represented by Theodore Roosevelt, Woodrow Wilson, Robert La Follette, and Josephus Daniels. According to Bates (1963, p. 1-13), conservationists and progressives agreed that (1) the Federal Government should act as steward of the publicly owned natural resources, (2) the common heritage should not pass into

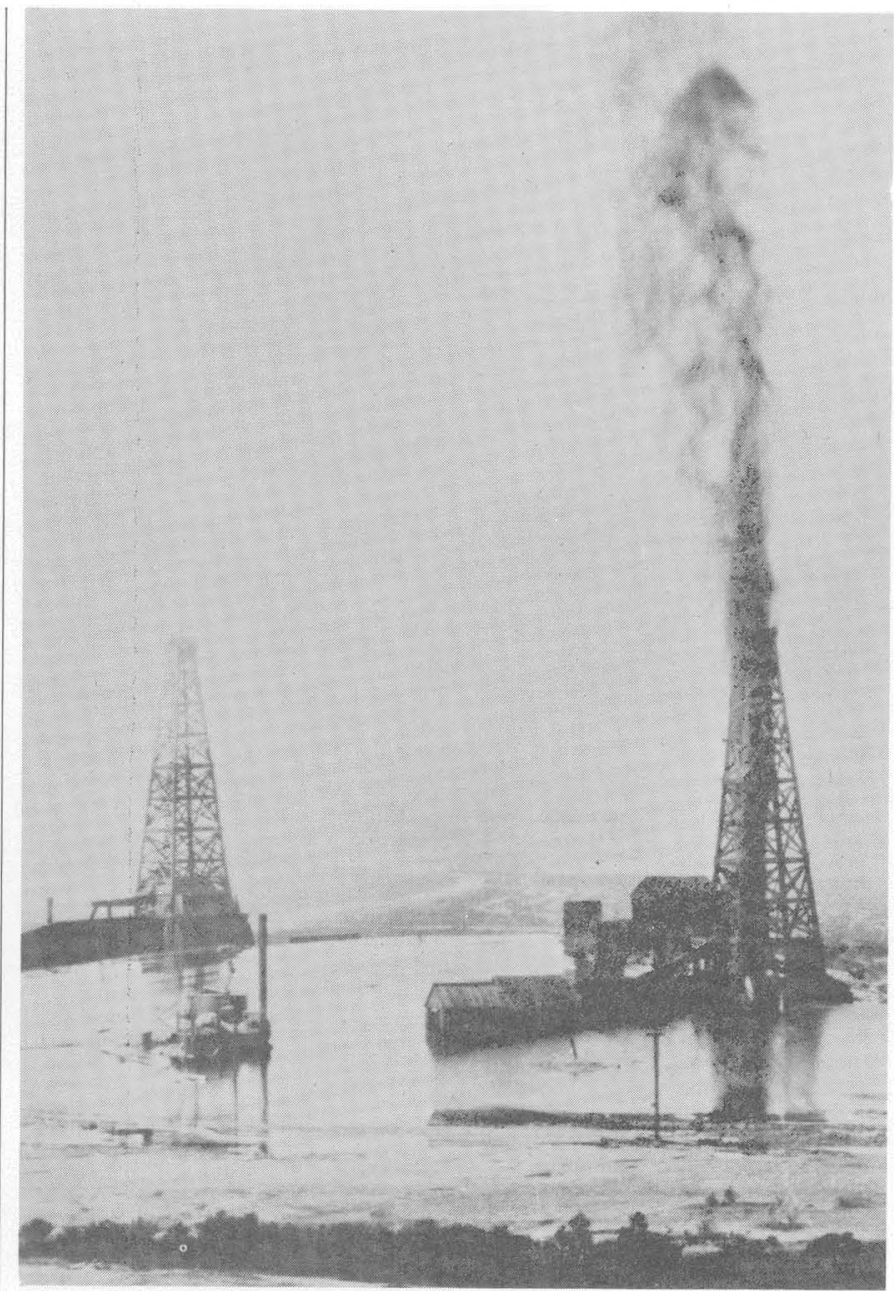

Figure 12.-The famous Lakeview gusher in the Midway-Sunset oil field near Taft producing 18,000 barrels of oil per day, March 1910.

the hands of vested interests, with the benefits accruing to a special few, (3) the wealth from the common heritage should be shared by all, and (4) the natural resources should not be wasted at the expense of future generations.

Largely as a result of publicity issued by the National Conservation Association, a well-financed, extremely effective group organized by Roosevelt and Pinchot, the public began to appreciate the fact that the natural resources of the United States were not inexhaustible. The conservationists attacked on a broad front; timber lands, coal lands, grazing lands, waterpower sites as well as oil lands were the targets of a vigorous, skillfully conducted publicity campaign. Pamphlets and editorials noted that the remaining public lands, concentrated in the Western states, were fast disappearing as a result of homesteading, patenting of mining claims, and 


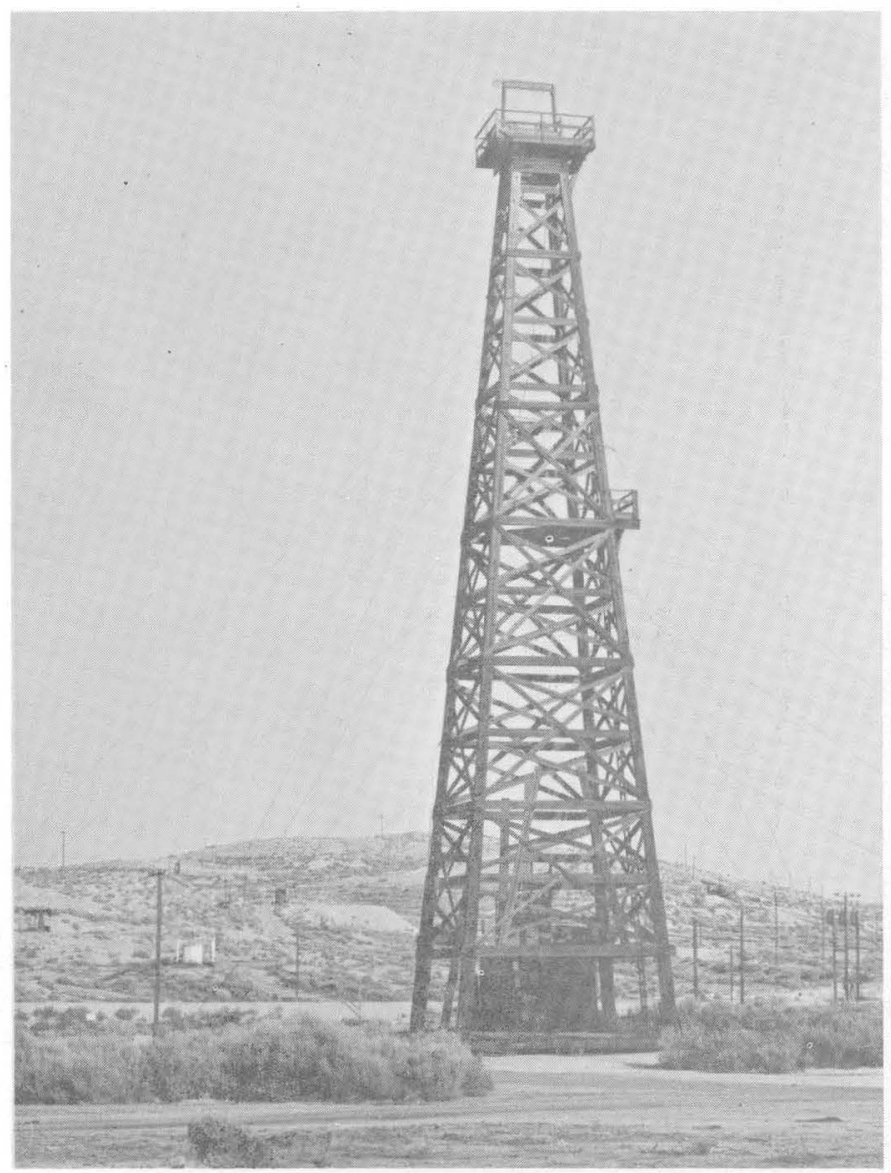

FIGURE 13.-Wooden derrick of cable-tool rig in Buena Vista oil field about half a mile north of Taft on State Highway 119. Wooden derricks were commonly used in this area during the period 1910-25.

granting of lands to states to support public schools and to railroad companies to help finance the construction of new railroads. They indicated that the natural resources of the public domain were dwindling rapidly and that too often these resources were being wasted (Bates, 1963, p. 1-13).

\section{OIL-FIELD WASTE AND ITS LEGAL CAUSE}

Waste was rampant in the early years of the oil industry on a scale that is hard to imagine now. In periods of frantic drilling to develop new fields, the glut of oil drove the price so low that oil was literally cheaper than water in many early oil fields. According to Ise (1926, p. 140-154), one enterprising fellow built a catch basin at the mouth of a ravine running through the young Kern River field in which he recovered 85 barrels of wasted oil per day for a period of 8 years. It was estimated that at least 4 million and possibly 8 million barrels of oil were lost to seepage and evaporation in the Midway-Sunset field alone in 1910 (Requa, 1911, p. 644). Arnold and Garfias (1914, p. 7) in 1914 predicted that not over

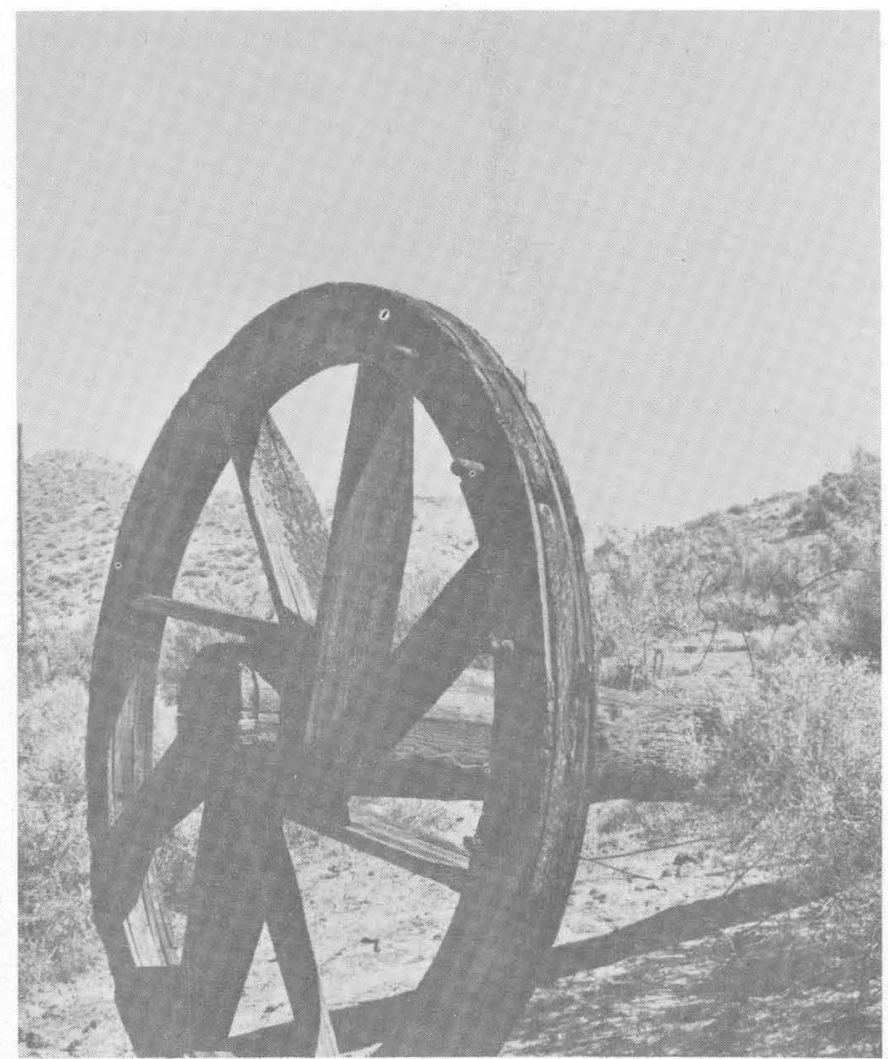

FIGURE 14.-Old bull wheel from cable-tool rig about one-quarter mile south of McKittrick on State Highway 58. Note pegs for takup slack in drilling line by hand. Diameter of wheel about 6 feet.

40-50 percent of the recoverable oil in the oil fields of California would ever be marketed.

The placer mining law encouraged, almost forced, overproduction with its attending waste. Two provisions of the placer law rendered it completely unsatisfactory for governing oil exploration. First, a claim was not valid until a discovery had been made, and second, the maximum area of a single claim could not exceed 20 acres. The prospector owned nothing until he made a discovery - he had to drill to claim his land. If he had several claims in an area, each claim had to have a discovery drilled on it before ownership passed on to him. With everyone drilling on small tracts of land, it became a race to produce the oil from the tract before it was drained by offset wells. The operator had to drill or lose his land and produce the oil or his neighbor would drain it from him. He had to produce even when it resulted in overproduction that drove the price of oil so low that it was impossible to make a profit.

\section{ROLE OF THE U.S. GEOLOGICAL SURVEY}

In view of the appalling waste and the desire of the Navy for an assured and adequate supply of fuel oil for its new oil-burning fleet (Ball, 1917, p. 18-22), many 


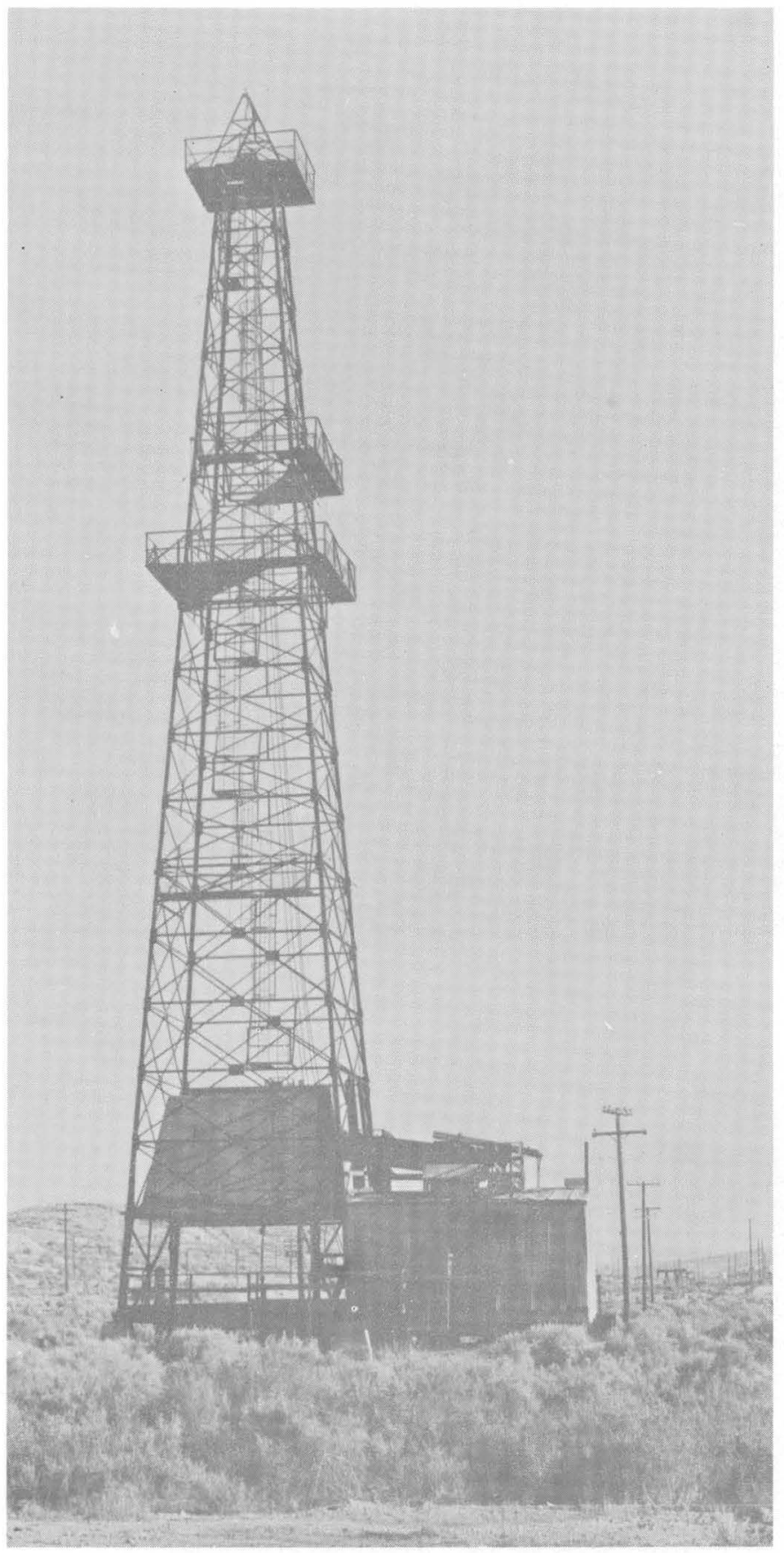

Figure 15.-Steel derrick in the Buena Vista oil field about half a mile north of Taft on State Highway 119.

scientists and public officials became alarmed at the situation. On February 24, 1908, Dr. George Otis Smith, Director of the U.S. Geological Survey, wrote to the Secretary of the Interior pointing out how rapidly the public oil lands were passing into private hands. He enclosed a copy of a Daily Consular Report regarding the increasing use of oil as a naval fuel and recommended that the United States Government retain con- trol of the public lands by withdrawing the remaining public oil lands from all forms of entry (Ball, 1917, p. 104-105). When this letter and report brought no action, Dr. Smith wrote additional letters to Interior Secretary Garfield about the waste of petroleum. On November 11, 1908, A. C. Veatch, D. T. Day, and Ralph Arnold, geologists and petroleum experts for the U.S. Geological Survey, wrote to the Director urging renewed efforts to obtain action on his recommendations of February 24, 1908, but it was not until the advent of the Taft administration that a new attempt was made.

Richard A. Ballinger replaced Garfield as Secretary of the Interior. Dr. Smith wrote Secretary Ballinger on September 17, 1909, again urging the withdrawal of public oil lands and enclosing a copy of his 1908 letter to Secretary Garfield. The same day Secretary Ballinger wrote President Taft recommending action on Dr. Smith's suggestions. After a conference with Smith and Ballinger in Salt Lake City, Utah, President Taft authorized the Department of the Interior to issue the withdrawal order. On September 27, 1909, the first withdrawal of public oil lands from all forms of entry was ordered (Ball, 1917, p. 113-149). The area that is now Naval Petroleum Reserve No. 1 was included in this first withdrawal.

\section{EFFECT OF WITHDRAWAL ORDER}

The withdrawal of September 1909 caught the oil industry by surprise. Operators were in all stages of development on public oil lands from staking locations to drilling into the oil sands, and title to oil lands representing a total investment of several million dollars was placed in peril. The effect of the withdrawal order as issued was to withdraw absolutely the selected public oil lands upon which no actual discovery had been made prior to September 27, 1909. Immediate cries of protest arose from the oil industry. Many companies with able legal staffs sincerely believed that the order was unconstitutional because it was not specifically authorized by Congress. President Taft himself had doubts about his power to make the withdrawal. Knowledge of the doubtful legality spread, and many operators simply disregarded the withdrawal order, not only to complete work on wells already started when the order was issued, but also to locate new wells on the withdrawn lands.

The confusion regarding the legality of the withdrawal order was finally settled by the passage of the Pickett Act on June 25, 1910, which confirmed existing withdrawals and authorized the President to make additional land withdrawals in the public interest. Under the provisions of this act, President Taft confirmed on July 2, 1910, the earlier withdrawals and by Executive Order again withdrew all public lands that were clas- 


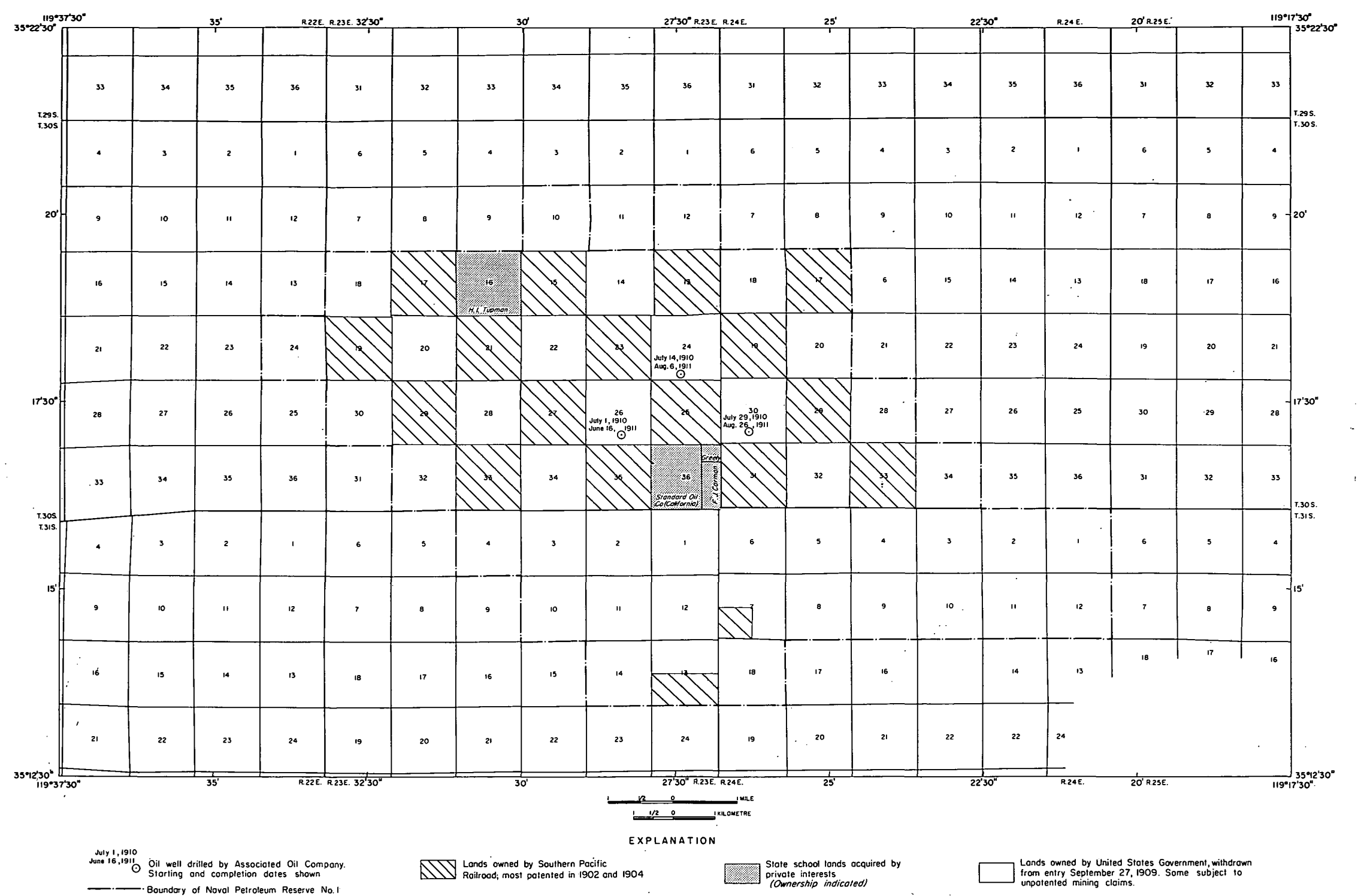

FIGURE 16.-Area, land ownership, boundary, and locations of oil wells in Naval Petroleum Reserve No.1 when established September 2, 1912. 
sified as oil lands, pending passage of an adequate oil and gas leasing law governing the public domain. The Pickett Act not only confirmed the previous withdrawals but also provided protection for those who were "bona fide occupants" of public land "in diligent prosecution of work leading to the discovery of oil or gas." The latter provision was to create many legal difficulties in years to come. It was doubly unfortunate because the need for the confirmation of withdrawals under the act disappeared with the United States Supreme Court decision on February 23, 1915. This was the landmark Midwest decision, which upheld the validity of the original withdrawals of September 1909, prior to the Pickett Act.

\section{RAILROAD LAND}

After the withdrawals of public oil land, Pinchot and other Progressives and conservationists noted the large amount of acreage patented to the Southern Pacific Railroad that was included within the areas considered to be capable of producing oil, 165,000 acres mostly in a band along the west side of the San Joaquin Valley from Coalinga to Sunset. The National Conservation Association mounted a publicity campaign arguing that these lands should be restored to the public domain because mineral lands were exempt from patent to railroads. President Taft requested Secretary of the Interior Ballinger to investigate the situation.

In December 1910, the United States Government filed the first of several suits against the Southern Pacific to restore to the public domain oil lands that had been selected for patent by the railroad. The purpose of the first suit, known as the Elk Hills Case, was to recover some 6,000 acres in the western Elk Hills that had been selected for patent by the railroad company in December 1904. Six additional suits were filed later involving about 160,000 acres that had been patented to the Southern Pacific at different times prior to 1904. The six suits were eventually consolidated into a single suit that was distinguished from the earlier suit by calling it the Consolidated Case. Included in the Consolidated Case were all remaining railroad lands in Elk Hills not covered by the Elk Hills Case. Decisions on both the Elk Hills and Consolidated Cases came in 1919 and are discussed later in relation to Naval Petroleum Reserve No. 1.

\section{ESTABLISHMENT OF NAVAL PETROLEUM RESERVE NO. 1}

\section{RECOMMENDATIONS OF U.S. GEOLOGICAL SURVEY}

In June 1912, the General Board of the Navy, heeding Dr. Smith's letter of 1908 , recommended to Secretary of the Navy George Meyers that permanent reservations be set aside to assure a future supply of fuel oil for the Navy. The Navy at that time was building the first United States battleships designed to burn oil exclusively, the Oklahoma and the Nevada. Accordingly,
Secretary Meyers wrote Secretary of the Interior Ballinger a letter dated June 25, 1912, stating "This Department therefore earnestly requests the cooperation of the Department of the Interior to secure a definite reservation for the Navy by Executive Order, of oilbearing public lands in California sufficient in extent to insure a supply of 500,000,000 barrels" (Tracie, 1937, p. 7). Secretary Ballinger conferred with the U.S. Geological Survey and replied July 22, 1912, to Secretary Meyers "I am further advised by the Geological Survey that there is one area within the lands in California covered by oil withdrawals, which area by reason of geological structure and isolated position is recommended by the Survey as best suited for the purpose of a permanent reserve for the Navy. This area is in the Elk

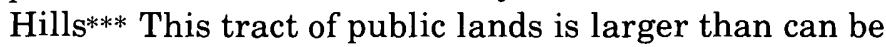
segregated, as a unit, in any other part of the California oil fields" (Richardson, 1916, p. 107).

\section{AREA AND OWNERSHIP}

On September 2, 1912, President Taft signed an Executive Order prepared by Dr. George Otis Smith creating Naval Petroleum Reserve No. 1. It appeared to include 12,103.09 acres of land patented to private interests, and 25,969.62 acres of public lands withdrawn from entry September 27, 1909. The area and apparent ownership of land within Naval Petroleum Reserve No. 1 at that time are shown in figure 16.

Naval Petroleum Reserve No. 1 was established subject to valid existing rights. Some public lands within the boundary of NPR-1 were subject to mining claims, mostly for fuller's earth. Most, if not all, such claims had been fraudulently located and had been long dormant despite the law that required a certain amount of labor or improvements on claims each year. The Navy expected a period of litigation to clear titles to some lands but felt that the NPR-1 was fairly secure from drainage except from the patented lands. Although the Associated Oil Company had drilled three discovery wells located on public lands within Elk Hills, the company did not pursue any claims, because the lands had been withdrawn September 27, 1909, almost 1 year before the wells were started.

\section{OPERATION OF NAVAL PETROLEUM RESERVE NO. 1}

CREATION OF NAVAL PETROLEUM RESERVE NOS. 2 AND 3

On March 4, 1913, the Wilson administration took office. The new Secretary of the Navy, Josephus Daniels, took an immediate personal interest in the Naval Petroleum Reserves. Naval Petroleum Reserve No. 2, located in the Buena Vista Hills just south of Elk Hills (fig. 4), had been created on December 13, 1912; about 3 months after the Elk Hills Reserve because of Navy fears that Elk Hills did not contain enough oil for the needs of the new oil-burning fleet. Josephus Daniels 
requested a third reserve, the Teapot Dome in Wyoming. President Wilson created Naval Petroleum Reserve No. 3 at Teapot Dome on April 30, 1915. It should be noted that all three Naval Petroleum Reserves were formed of public oil lands previously closed to entry by the withdrawal order of 1909.

\section{LITIIAATION OVER RAILROAD LAND}

The United States Supreme Court on February 23, 1915, rendered the Midwest decision, which upheld the validity of the land withdrawals of September 1909. This strengthened the Government's claim to the unpatented lands within NPR-1 at Elk Hills and NPR-3 at Teapot Dome, where little or no drilling had been done. However, NPR-2 at Buena Vista Hills, where drilling and leasing preceded the land withdrawals of 1909 , had been withdrawn too late to be reserved as a whole. The value of the two California tracts as Naval Petroleum Reserves hinged on the two court cases against the Southern Pacific Railroad, which held patent to every alternate section in Buena Vista Hills and to $163 / 4$ sections in Elk Hills. The Elk Hills Case was directed at $91 / 2$ sections, about 6,000 acres, in western Elk Hills. The Consolidated Case involved about 20,000 acres within the two California reserves-the remaining $7 \frac{1}{4}$ sections of railroad land in the Elk Hills not involved in the Elk Hills Case and about 24 sections of railroad land in the Buena Vista Hills.

The Southern Pacific tried to have the Consolidated Case thrown out of court primarily on the basis that the statute of limitations had run before the suit was filed, an assertion that they could not make in the Elk Hills Case. The Government argued that if the patents were obtained fraudulently and the fraud was concealed, the statute of limitations could not bar the suit. The United States District Court held for the Government.

The Elk Hills Case, filed in 1910 , came to decision in District Court, June 9, 1915, with the court finding for the Government. Southern Pacific immediately appealed. In May 1918 the Circuit Court of Appeals reversed the decision of the District Court by finding for the Southern Pacific. In the meantime, the Consolidated Case was nearing a decision. On August 28, 1919, the United States District Court rendered a decision against the Government in the Consolidated Case. The judge took cognizance of the similarity of the Consolidated Case and the Elk Hills Case in his written decision and cited the decision of the Court of Appeals against the United States in support of his conclusion. Ironically, 2 months later, November 17, 1919, the Supreme Court reversed the decision of the Court of Appeals in the Elk Hills Case, finding in favor of the United States. On the basis of documentary evidence that convinced the Supreme Court that "fraud was so well proved it was beyond dispute," it would seem that the Government had a chance to win an appeal of the Consolidated Case. This was especially so since the District Court had decided the Consolidated Case on the authority of a similar decision by the Court of Appeals in the Elk Hills Case, later reversed by the Supreme court. Nevertheless, Attorney General A. Mitchell Palmer on December 5, 1919, announced there would be no appeal. The ownership of lands included in Naval Petroleum Reserve No. 1 following the final decisions in the Consolidated Case and the Elk Hills Case is shown on figure 17.

\section{HAY-CARMAN AND TUPMAN DISCOVERIES ON SCHOOL LAND}

The entry of the United States into World War I brought increased exploration and drilling activity throughout the country, but especially in California. In 1910 the Standard Oil Company (California) had purchased the Hay lease, which covered most of sec. 36, T. 30 S., R. 23 E., a school-land section near the center of the Elk Hills Naval Reserve, and the Tupman lease on all of sec. 36 , T. 30 S., R. 24 E., a school-land section adjacent to the northeast corner of the NPR-1. Because of the wartime demand for oil, Standard was drilling many exploratory wells and in the summer of 1918 decided to drill a well to test the Hay lease.

The Standard Oil Company (California) Hay No. 1 well (fig. 17) was completed in January 1919 at a total depth of 2,532 feet with an initial flow of 256 barrels of $37^{\circ}$ gravity oil per day from what is now called the Shallow Oil Zone. Despite the three successful wells drilled about 1911 in Elk Hills by the Associated Oil Company, the Hay No. 1 is generally regarded as the discovery well of the Elk Hills oil field. The Hay No. 2 and Hay No. 3 wells were completed with yields of 350-450 barrels of oil per day in April of 1919. On July 26 of the same year, the Hay No. 7 well (fig. 18) blew out and caught fire while producing an estimated 180 million cubic feet of dry gas per day. A column of flame, 200 feet high, was visible for 80 miles, and the roar of the fire was heard 9 miles away. After burning for 10 days, the fire was extinguished by the use of dynamite, and the gas flow was controlled. Seven other gas wells were completed on the Hay lease, and at least one other burned, the Hay No. 8 shown in figure 19. By the end of 1926, the gas discovery well (Hay No. 7) had produced an unprecedented 43 billion cubic feet of dry gas and was labeled the world's most productive gas well in the trade journals.

About this time, Standard purchased the Carman lease, which covered most of the rest of the section in which the Hay lease was located, and started drilling operations. On September 28, 1919, the Standard Oil Company (California) Carman No. 1 well located on the newly obtained lease blew in. While blowing wild, it produced an estimated 20 million cubic feet of gas and 10,000 barrels of $41^{\circ}$ gravity oil per day. It was killed 


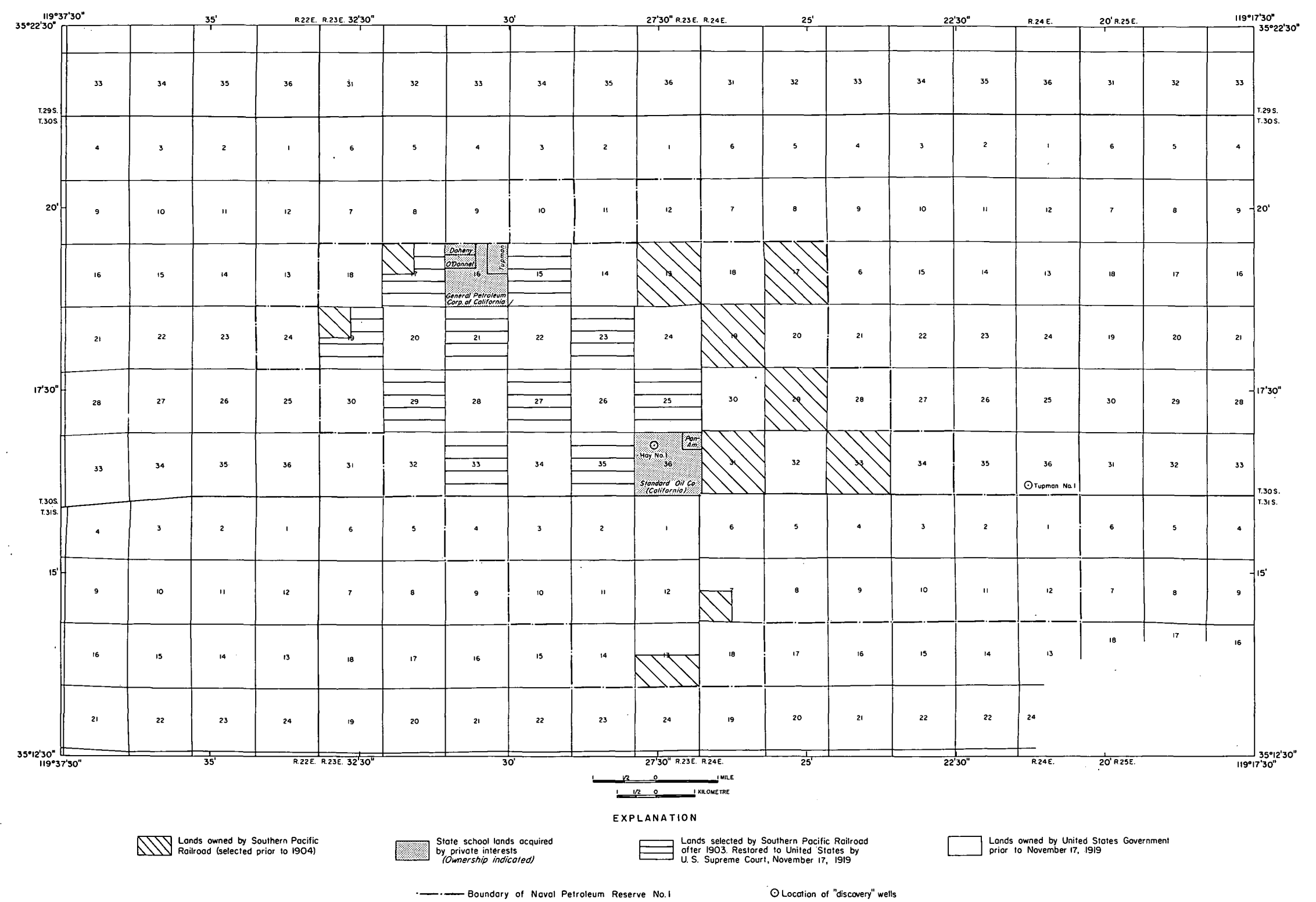

FIgURE 17-Land ownership of Naval Petroleum Reserve No. 1 after United States Supreme Court decision of November 17, 1919. 


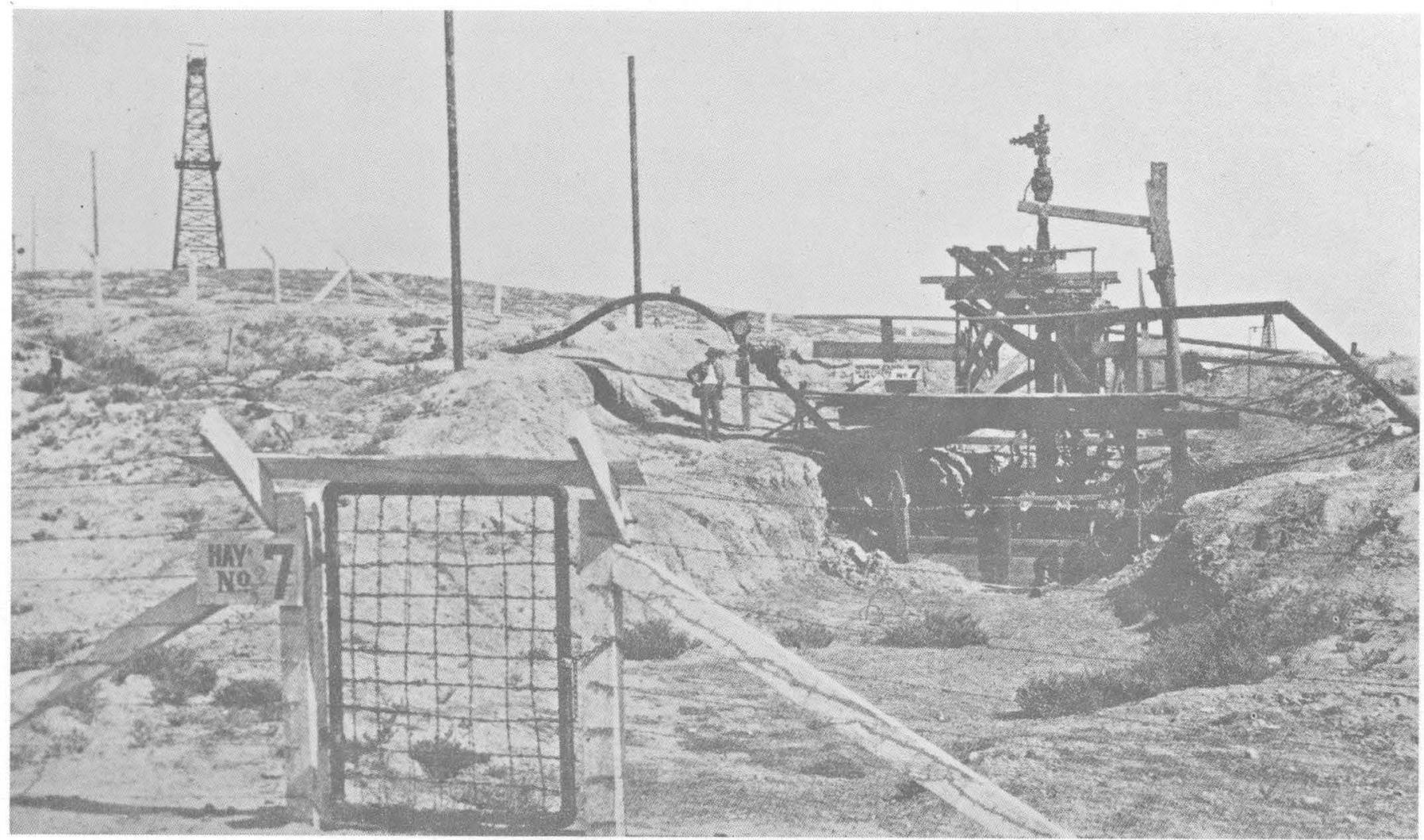

Figure 18-The Hay No. 7 well which discovered the Dry Gas Zone at Elk Hills in 1919 and was known in 1927 as the world's most productive gas well.

October 10 , redrilled, and completed for 5,000 barrels of oil per day. Thereafter, the Hay-Carman tract was rapidly developed.

In October 1919, Standard started the Tupman No. 1 well near the northeast boundary of the reserve (fig. 17). The Standard Oil Company (California) Tupman No. 1 well came in February 12, 1920, with a flow of about 6,000 barrels of $24^{\circ}$ gravity oil per day. Fourteen more wells were drilled on the Tupman lease before the end of the year. The two producing areas, about 6 miles apart, were then called the Western field (Hay-Carman area) and the Eastern field (Tupman area). The two areas were producing large amounts of oil and were almost surely draining oil from the offsetting Navy lands.

\section{OIL- AND GAS-LEASING LAW}

The United States Congress finally agreed on an oiland gas-leasing law after 10 years of often acrimonious debate. The bill, signed into law by President Wilson, February 25, 1920, took special notice of the Naval Petroleum Reserves. The law provided that claimants to lands within the reserves would be given leases only to producing wells and covering only sufficient acreage to operate the wells. The President, at his discretion, could permit leases on the remainder of the claims. No producing wells were located on public lands within Naval Petroleum Reserve No. 1 at that time.

\section{NAVY CONTROL}

In order to keep himself better informed about developments in the Naval Reserves, Secretary of the Navy Daniels established in April 1920 what amounted to a small separate bureau to handle Naval Petroleum Reserve matters. The oil desk, as it was called, was put under Daniels' personal supervision, and personnel assigned to it reported directly to the Secretary. Most effort of the oil desk during this period was applied to the problem of how best to prevent drainage of Navy oil.

On June 4, 1920, Congress passed the Naval Appropriations Act, which had been modified at the request of Secretary Daniels to place the Naval Petroleum Reserves in the possession and under the authority of the Secretary of the Navy. The Secretary was directed in a part of this act "to conserve, develop, use, and operate the same in his discretion, directly or by contract, lease, or otherwise, and to use, store, exchange, or sell the oil and gas products thereof, and those from all royalty oil from lands in the naval reserves for the benefit of the United States***." These were rather broad powers 


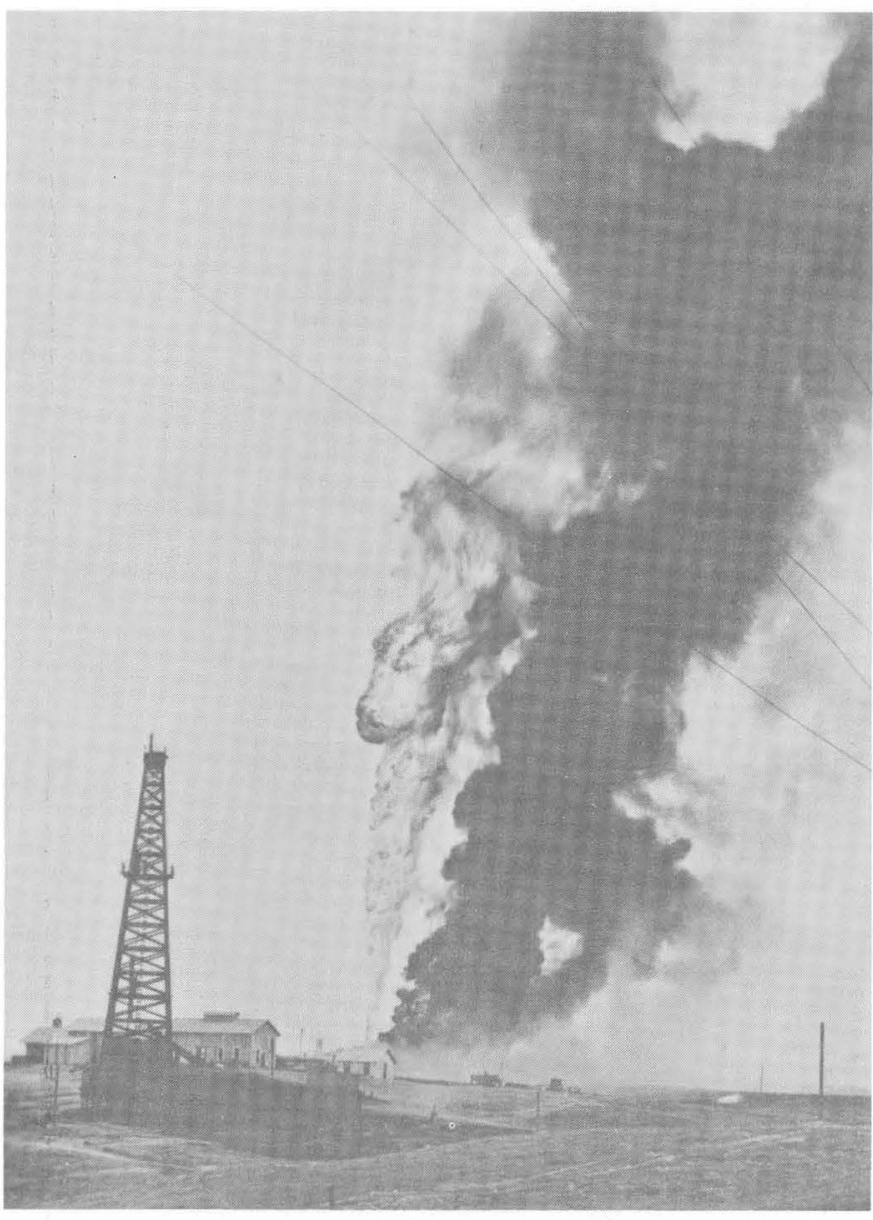

Figure 19-The Hay No. 8 gas well at Elk Hills burning in 1920.

which the Navy later used to exchange crude oil for construction at the Pearl Harbor Naval Base.

With some measure of control over the Naval Petroleum Reserves now placed in the Department of the Navy, Secretary Daniels turned his attention to minor claimants and drainage problems in NPR-1. The Navy arranged to trade leases outside NPR-1 for quitclaim deeds to claims of the Associated Oil Company and the Eight Oil Company inside the reserve. Also included in the trade was the relinquishment of $621 / 2$ acres in the NW1/4 sec. 16, T. 30 S., R. 23 E., by E. L. Doheny (fig. 17). In return for all claims in NPR-1, Associated was granted a lease on the $\mathrm{SE}^{1} 1 / 4$ sec. 26 , T. 30 S., R. 24 E., and Eight Oil Company was granted leases on the SW1/4 sec. 26, T. 30 S. R. 24 E., and the NW $1 / 4$ sec. 6 , T. 31 S., R. 25 E. The leases were issued February 25, 1921. Less than 1 month later the Eight Oil Company leases had been assigned to third parties-the lease on sec. 6 to E. L. Doheny who subsequently assigned it to Pan American Petroleum Company and the lease on sec. 26 to the Union Oil Company (fig. 20).

\section{DRAINAGE PROBLEMS}

The question of how to prevent drainage of Navy oil by the Standard Oil Company production in the HayCarman and Tupman areas was being considered by Secretary Daniels during the last months of his incumbency. It was decided to drill two rows of offset wells on Navy land opposite Standard's producing areas.

Southern Pacific Railroad land in the Elk Hills Reserve had not been a particular worry to the Navy prior to 1920 , for it was the policy of the railroad to drill its land only when threatened by drainage from offset wells. However, on January 1, 1921, the Southern Pacific Railroad formed an independent company called the Pacific Oil Company. When the new company was formed, the railroad turned over its oil properties in California plus 51 percent of the stock of the Associated Oil Company. The Pacific Oil Company, thus formed, owned sections offsetting both the Hay-Carman and Tupman leases. In January 1921, Pacific started drilling on their lands to prevent drainage by the wells of Standard Oil Company (California) on the Hay-Carman and Tupman leases.

In early February of 1921, a startling discovery was made in the General Land Office of the Department of the Interior concerning the status of two school-land sections in NPR-1, one of which was the section containing the now-productive Hay and Carman leases. Nearly 8 years earlier, in April 1913, while examining information on patented lands inside Naval Petroleum Reserves in support of the Government's cases against the Southern Pacific Railroad, the examiners had called attention of the Commissioner of the General Land Office to two school-land sections within Naval Petroleum Reserve No. 1. Mineral lands were specifically exempted from patent as school or railroad lands. However, the sections had been passed to the State of California in 1903 before the establishment of NPR-1. The Commissioner wrote a letter on January 14, 1914, directing the Visalia, California field office to institute proceedings to recover the school-land secs. 16 and 36, T. 30 S., R. 23 E. (fig. 17). Somehow the letter was misfiled in the Visalia office, and the requested action was never taken. This letter was discovered in the dead files in February 1921, and called to the attention of the General Land Office in Washington. On March 2, 1921, the Commissioner of the General Land Office again directed the Visalia office to institute proceedings against the lands in question. Owing at least partly to these complications, Secretary of the Navy Daniels was unable to take action to stop the drainage of oil from Navy lands before leaving office. (See the following section "School-land Recovery.")

\section{TRANSFER OF NAVAL PETROLEUM RESERVES TO INTERIOR}

The Harding administration took office March 4, 1921, with Edwin Denby as Secretary of the Navy and 


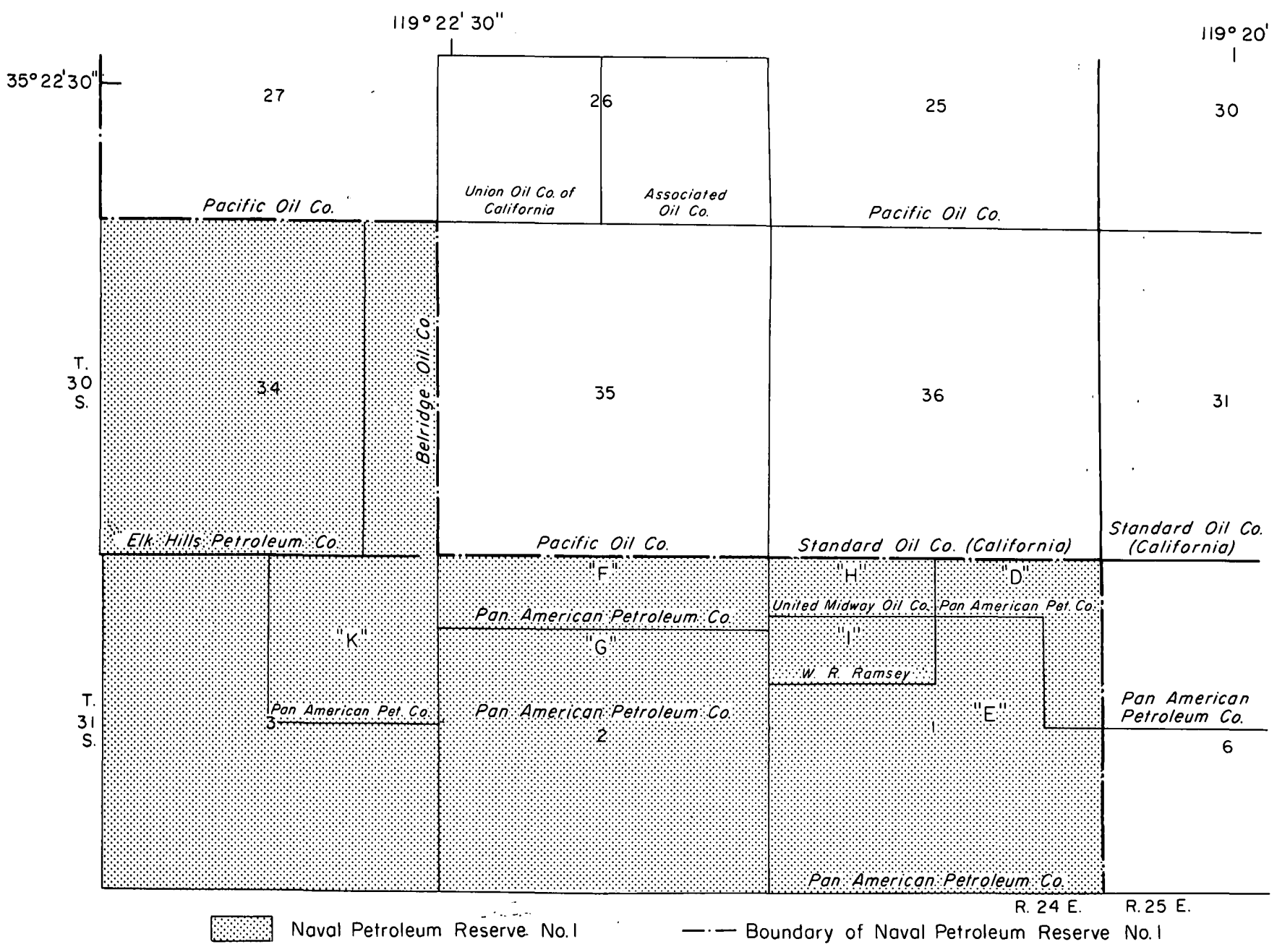

Figure 20-Leases issued in Naval Petroleum Reserve No. 1, 1921 and 1922.

former senator Albert B. Fall of New Mexico as Secretary of the Interior. Fall, with a then-traditional western philosophy toward the public domain, had been an outspoken critic of conservationists in the past. He favored the rapid development of publicly owned resources by private industry and actively pursued that policy as Secretary of the Interior. On May 31, 1921, President Harding signed Executive Order 3474 transferring the responsibilities of the Secretary of the Navy in regard to the Naval Petroleum Reserves, delineated in the act of June 4, 1920, to the Secretary of the Interior. Fall evidently drafted the Executive Order for the President's signature, although Denby approved the draft before it was forwarded to the President for signing.

\section{CANCELLATION OF SCHOOL-LAND LAWSUIT}

Soon after Secretary Fall took office, representatives of the Standard Oil Company (California) called upon him urging the cancellation of the lawsuit that had been filed in regard to the school-land section on which the Hay and Carman leases were located. According to later testimony in the U.S. Senate Hearings (1924, p. 3349), Fall convened a hearing on the matter the afternoon of June 8, 1921, and after listening to the argument of Standard's representative, cancelled the lawsuit later the same afternoon without filing a written decision. Drainage of NPR-1 continued.

\section{ROYALTY BIDDING FOR OFFSET WELLS}

Before the transfer of the Naval Reserves to Interior, the Navy had advertised for bids at advanced royalty rates for the drilling of 22 wells in sec. 1, T. 31 S., R. 24 E., to offset Standard's wells on the Tupman lease from producing oil originally in place under the contiguous Navy land (fig. 20). The bids were opened July 8, 1921, after the administration of the Naval Petroleum Reserves had passed to the Secretary of the Interior. Secretary Fall determined that the offer of 55 1/2-percent 
royalty made by Pan American Petroleum Company, controlled by E. L. Doheny, was the best bid. An application by the United Midway Oil Company for a lease on part of sec. 1, T. 31 S., R. 24 E., was pending at the time the bids were opened. The claim was based on a dry hole drilled by the company prior to July 2,1910 , in adjacent sec. 12. The claim had been denied previously on the grounds that, in the absence of any discovery of oil or gas, no mining claim could be patented and no valid claim against the United States existed. Secretary Fall examined the application and found that the United Midway Oil Company had no legal right to any land in NPR-1 but that its expenditures on the nearby dry hole had created an equity that should be recognized. Fall proposed that United Midway should be granted 8 of the proposed 22 offset wells if the company would pay 55 $1 / 2$-percent royalty and give quitclaims to any rights to lands in NPR-1. Doheny agreed to give up eight of the wells granted to Pan American Petroleum Company. On June 8, 1921, the " $\mathrm{H}$ " lease, the first one granted in NPR-1, was issued to the United Midway Oil Company. The second lease, the "D" lease, was issued to the Pan American Petroleum Company July 12, 1921 (fig. 20). The United Midway Oil Company assigned the " $\mathrm{H}$ " lease to W. R. Ramsey on August 8, 1921.

On November 22, 1921, Secretary Fall received a letter from the Pan American Petroleum Company, operator of the "D" lease (fig. 20), pleading for relief from the $551 / 2$-percent royalty rate because the price of oil had declined 50 cents a barrel. On November 23 , a similar letter was received from W. R. Ramsey, operator of the "H" lease (Tracie, 1937, p. 239; U.S. Senate Hearings, 1924, p. 3518-20). Secretary Fall denied the appeals for a reduction in royalty rates but agreed to lease the rest of sec. 1 to the two companies at the regular royalty rate ( $12 \frac{1}{1 / 2}$ percent). On December 14,1921 , the "I" lease was issued to W. R. Ramsey and the "E" lease to Pan American Petroleum Company (fig. 20).

On November 30, 1921, the Bureau of Mines, at the direction of Secretary Fall, had prepared an invitation for bids on offset leases in sec. 6, T. 31 S., R. 24 E., and sec. 25, T. 30 S., R. 23 E., adjacent to Standard's HayCarman area and for offset leases along the north side of sec. 2, T. 31 S., R. 24 E., at the east end of NPR-1. Wells on the lease in sec. 2 were to offset wells planned by the Pacific Oil Company along the south line of sec. 35 (fig. 20 ). Several bids were received and tabulated December 29, 1921. All bids for leases on secs. 6 and 25 adjacent to the Hay-Carman area were rejected. A bid of 35-percent royalty submitted by the Pan American Petroleum Company on the northern part of sec. 2 was accepted. Then it was discovered that no lease could be issued on sec. 2 because the section was covered by applications for the patent of mining claims for fuller's earth. Pan
American countered with an offer to Secretary Fall to deliver quitclaims for all mining claims in sec. 2 in return for the lease on the northern part of the section at the 35-percent royalty bid and a lease on the rest of sec. 2 at the regular royalty. The offer was accepted, and on February 8, 1922, the " $F$ " lease was issued to Pan American Petroleum Company at 35-percent royalty and the "G" lease to the same company at regulation royalty (fig. 20) (Tracie, 1937, p. 128-132).

On April 24, 1922, a lease along the east side of sec. 34, T. 30 S., R. 24 E., was issued without advertising or competitive bidding to the Belridge Oil Company. Wells on this lease were to offset wells that the Pacific Oil Company planned to drill in the adjoining sec. 35 .

\section{CRUDE-OIL EXCHANGE FOR PEARL HARBOR CONSTRUCTION}

In the middle of October 1921, Secretary of the Navy Denby abolished the oil desk established by former Secretary Daniels and placed the supervision of the Naval Petroleum Reserves in the Bureau of Engineering under Admiral John K. Robison. Robison previously had been involved in contingency plans for naval operations in the Pacific in case an emergency developed with Japan. Some top-ranking Navy officers, including Admiral Robison, were apprehensive about Japan's intentions during the years 1920 to 1924 and were actually anticipating an attack in the Pacific by the Japanese (Stratton, 1957, p. 392). Pinched by the economies of postwar isolationism, the short-funded Navy searched for ways to construct a fuel depot at Pearl Harbor, a high-priority item in naval plans for national defense. Robison hit upon the idea of exchanging the royalty oil produced from the Naval Petroleum Reserves for the construction of the Hawaiian fuel depot (U.S. Senate Hearings, 1924, p. 912). Authority to make the contemplated exchange was found by the Judge Advocate General of the Navy in the Naval Appropriation Act of June 4, 1920.

On October 25, 1921, Secretary Denby wrote to Secretary Fall requesting that the Department of the Interior handle all arrangements for the exchange. Letters calling for bids by April 15, 1922, on the construction and filling of 1.5 million barrels of fuel-oil storage at Pearl Harbor were sent to the Associated Oil Company, Standard Oil Company (California), and Pan American Petroleum Company. Standard Oil Company (California) refused to bid on the advice of their attorney who held that neither Navy nor Interior had the authority to exchange crude oil for construction work under existing laws. Associated submitted a bid but specified that the bid was submitted subject to the ratification and confirmation by Congress of the authority of the Secretary of the Interior and the Secretary of the 
Navy to make such an exchange. Pan American Petroleum Company submitted two bids. The first would fulfill the contract in exchange for crude oil worth $\$ 6,701,979.90$ at existing prices; the second, for crude oil amounting to $\$ 6,466,795.50, \$ 235,184.40$ less than the first proposal, but with the stipulation that the Pan American be granted the preferential right to drill any lands within Naval Petroleum Reserve No. 1 that the Government might decide to lease in the future. The second Pan American proposal was recommended by representatives of Navy and Interior and was accepted April 25, 1922. Under the terms of the contract, the " $\mathrm{K}$ " lease on the $\mathrm{NE}^{1 / 4} \mathrm{sec} .3$, T. 31 S., R. 24 E., was issued to Pan American Petroleum Company on June 5, 1922 (fig. 20).

On November 29, 1922, the Secretary of the Navy wrote Secretary Fall requesting that the contract of April 25, 1922, with the Pan American Petroleum Company be extended to provide for the construction of additional storage tanks filled with fuel oil at Pearl Harbor. Secretary Denby also suggested in his letter that Pan American would agree to undertake the additional work if they were allowed to do additional drilling in NPR-1 (Tracie, 1937, p. 241-242). In compliance with the Navy request, the Department of the Interior entered into a supplemental agreement with the Pan American Petroleum Company on December 11, 1922, providing for the construction and filling of 2.7 million barrels of additional tankage at Pearl Harbor to be paid for by royalty oil produced from NPR-1 and NPR-2. Because the royalties from the two California reserves would not liquidate the costs of the work in a reasonable length of time, Pan American was authorized to drill additional wells in NPR-1. The company was also issued a lease for all public land remaining unleased within NPR-1. This put all of NPR-1 in private hands. Figures 21 and 22 show the state of development of the Elk Hills oil field in 1922-24.

\section{SENATE INVESTIGATIONS AND RESULTS}

In April 1922, Senator Robert M. La Follette of Wisconsin succeeded in obtaining passage of two important resolutions by the Senate. The first resolution directed the Secretary of the Interior to send to the Senate all documents relating to the leasing of the Naval Petroleum Reserves. The second authorized the Senate Committee on Public Lands to investigate the entire subject of leases on all naval oil reserves. At La Follette's request, Senator Thomas J. Walsh, one of the few opposition party members of the Committee on Public Lands, was appointed to lead the investigation.

In June 1922, Secretary Fall, in response to the Senate resolution, sent all the naval oil reserve documents to the committee accompanied by a letter of transmittal from President Harding stating that he knew and approved of the transactions. Senator Walsh and the committee needed time to assimilate the mass of material; as a result, the hearings did not begin until October 22,1923 . By that time President Harding had died in office (Aug. 2, 1923), and Secretary Fall had resigned his post (March 4, 1923). The Senate investigations went on for several years before arriving at the following conclusions: (1) Some leases on Naval Petroleum Reserve No. 1 were executed under circumstances indicating fraud (Tracie; 1937, p. 273), (2) the leases and construction contracts were issued without authority and in violation of the laws of Congress and were therefore illegal and subject to cancellation (Tracie, 1937, p. $273)$, (3) the concept of drilling and producing the Naval Petroleum Reserves to obtain royalty oil to pay for construction work was originated by Admiral Robison (U.S. Senate Hearings, 1924, p. 932), (4) Albert B. Fall had received $\$ 100,000.00$ from Doheny while occupying the position of Secretary of the Interior (U.S. Senate Hearings, 1924, p. 1772), (5) the school-land sections in Naval Petroleum Reserve No. 1 (secs. 16, 36, T. 30 S., R. $23 \mathrm{E}$., fig 23) were known to be mineral in character when granted to the State of California and should therefore be recovered by the United States (Tracie, 1937, p. 308), and (6) Executive Order 3474 transferring responsibility for the Naval Petroleum Reserves from the Secretary of the Navy to the Secretary of the Interior was illegal and should be set aside (Tracie, 1937, p. 289).

As a result of these conclusions; the United States Government took the following six actions: (1) Executive Order 4614 was issued by President Coolidge on March 17, 1927, revoking Executive Order 3474 and restoring jurisdiction of the Naval Petroleum Reserves to the Secretary of the Navy; (2). on May 8, 1925, Secretary of the Interior Hubert Work reinstated proceedings against the two school-land sections in Naval Petroleum Reserve No. 1; (3) the U.S. District Court cancelled the construction contracts and the associated leases on NPR-1 in a decision rendered May 28, 1925. The United States Court of Appeals upheld the District Court decision on January 4, 1926. The Supreme Court concurred in the decisions February 28, 1927. The Pan American Petroleum Company paid a judgment to the United States amounting to $\$ 13,013,151.76$. On August 26,1927 , the cancelled leases were returned to the Navy; (4) the protective lease issued to the Belridge Oil Company (fig. 20) was attacked in the courts, but the lease was held to be valid and necessary to prevent drainage of oil from NPR-1; (5) the United States instituted legal proceedings to recover the "E," and "G," and "I" leases in NPR-1 issued to the Pan American Petroleum Company and to W. R. Ramsey. On November 


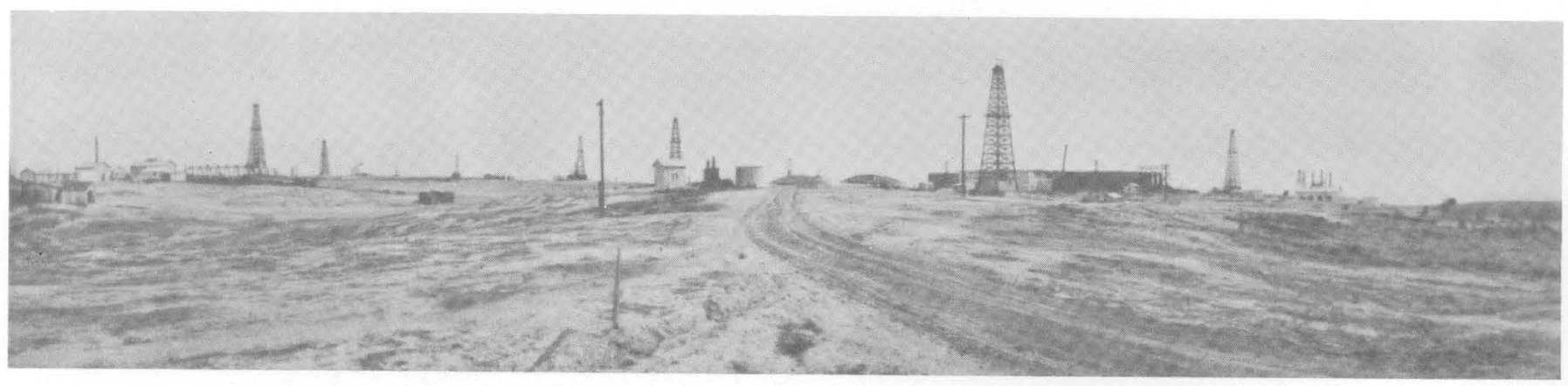

FIGURE 21.-Wells on the Hay lease (36R) in Elk Hills about 1922.

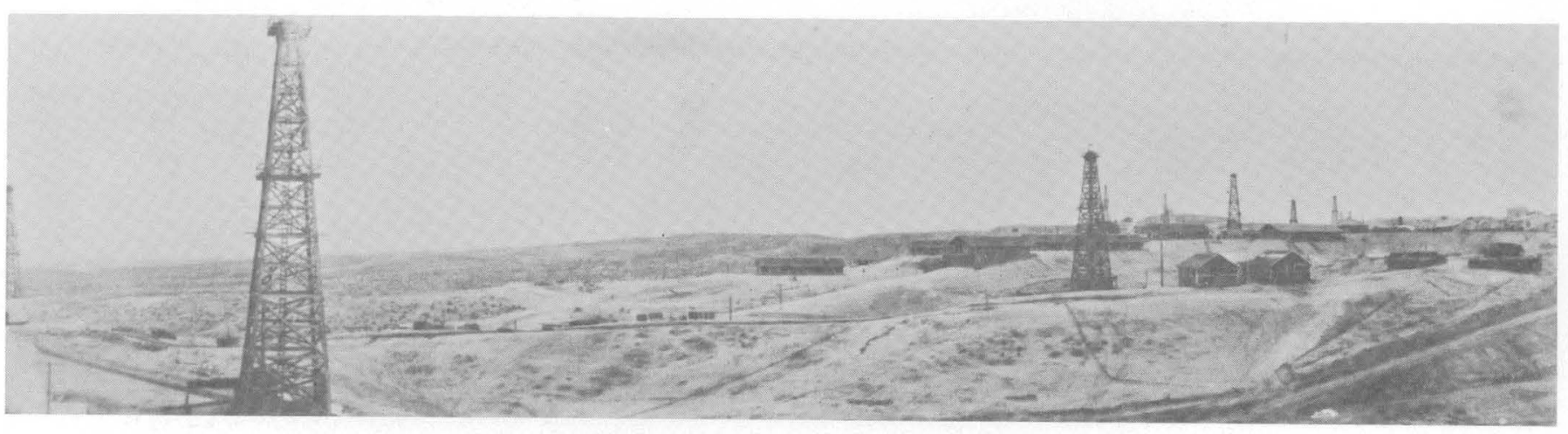

Figure 22.-Pan American Oil Company 2G Camp in the Elk Hills oil field, December 1924.

10, 1930, the United States District Court ruled against the Government, but the United States Court of Appeals reversed the decision of the lower court on February 5, 1932. The Supreme Court denied a request for appeal on November 7, 1932. The leases were returned to the Navy December 9, 1932, and a judgment of $\$ 8,691,214.28$ was paid to the United States; (6) several criminal cases were instituted in the wake of the investigations, but only one case involving the issuance of the leases was successful. Albert B. Fall was sentenced to 1 year in jail and a fine of $\$ 100,000.00$ on October 25, 1929. He served 9 months and 19 days with time off for good behavior. Fall died late in 1944 convinced that the Japanese attack on Pearl Harbor vindicated his policies of 20 years earlier.

\section{SCHOOL-LAND RECOVERY}

When the United States Senate passed a resolution on February 21, 1924, directing the Secretary of the Interior to institute proceedings to recover secs. 16 and 36, T. 30 S., R. 23 E. (fig. 23) for the United States, the school-land case that had its beginnings 10 years before, as discussed previously, was reopened. On May 8, 1925, Secretary of the Interior Hubert Work directed the Land Office at Visalia, Calif, to conduct hearings on the tracts. Standard Oil Company promptly filed for an injunction to restrain the Secretary of the Interior from continuing proceedings against the lands. After nearly 4 years of litigation, the Supreme Court rendered a decision in favor of the Government on January 2, 1929, authorizing the Secretary of the Interior to conduct the proceedings. On February 24, 1932, after conducting the hearings, the Land Office at Visalia ruled against the recovery. The case was appealed to Commissioner C. C. More of the General Land Office, who asked several representatives of the Land Office to review the case. These representatives wrote an opinion in favor of the United States and presented it to the Commissioner on February 23, 1933. The Commissioner did not agree and wrote an opinion on the same date against the Government. The case was finally appealed to Secretary of the Interior Harold Ickes. Secretary Ickes in a lengthy decision ruled on January 24, 1935, that the land was known to be mineral at the time title was transferred to the State of California (Warren, 1938, p. 121-187). He denied a plea for rehearing on May 20, 1936.

On April 22, 1937, the Doheny interests quitclaimed all interest in sec. 36 (lots 1 and 2, fig. 17) to the United States and paid $\$ 100,000$ as a compromise settlement for all claims against them. After another series of appeals, the Supreme Court denied a request for a writ of certiorari by Standard on January 29, 1940. A petition for rehearing was refused on March 25, 1940. On March 27, 1940, the Standard Oil Company of California sur- 


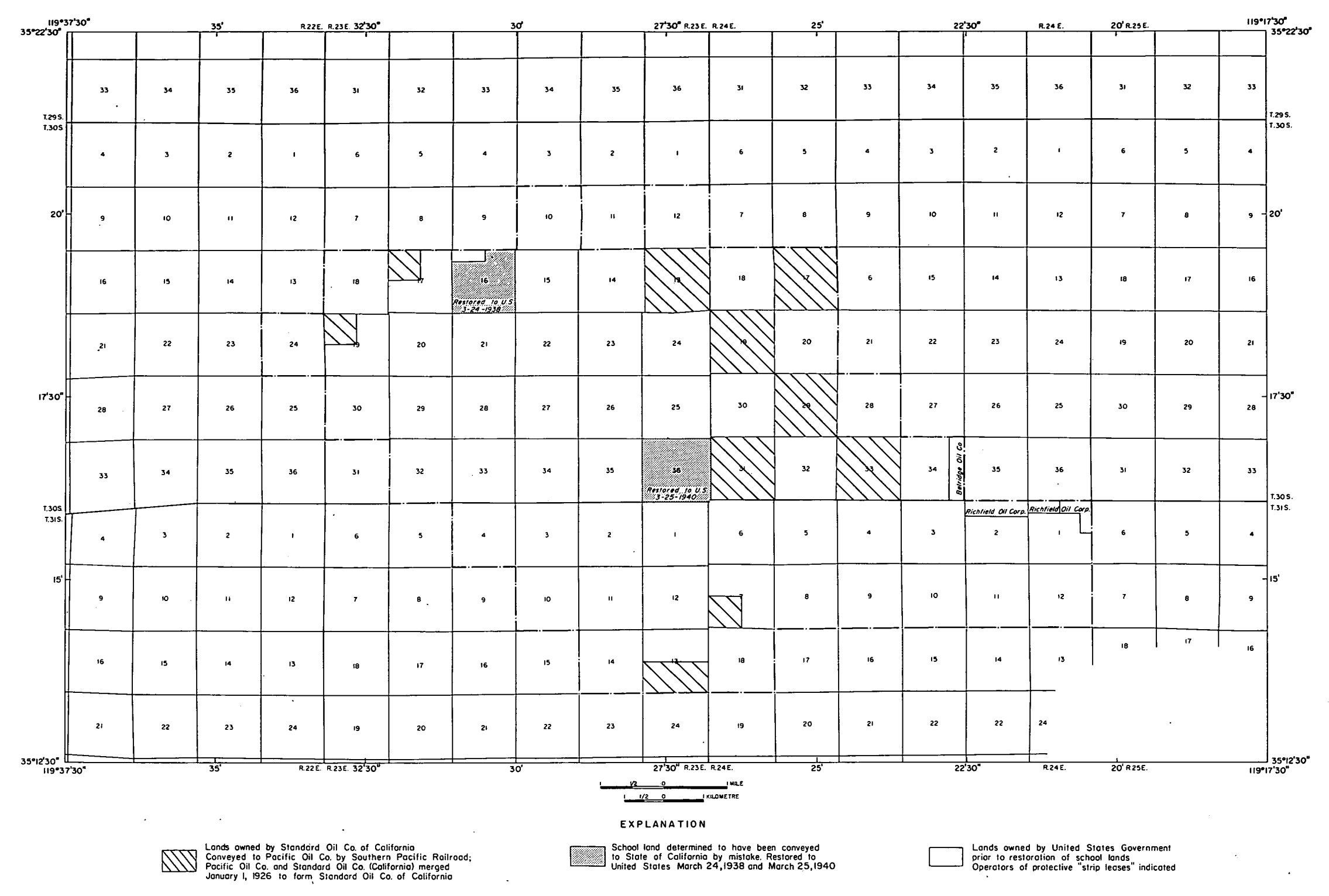


rendered its leases in sec. 36 , on which the so-called discovery well of the Elk Hills oil field had been drilled in 1919 , and paid a judgment of $\$ 7,138,297.40$. Sec. 16 had been returned to the United States on March 24, 1938. Ironically, Standard had decided in 1910 to purchase only school-land sections in the areas of the early public-land withdrawals in the belief that they were the only lands with a clear title available at that time.

\section{RETURN TO NAVY CONTROL}

After the disclosures resulting from the Senate investigations into the leasing of the Naval Petroleum Reserves, President Coolidge on March 17, 1927, transferred the jurisdiction over the reserves back to the Secretary of the Navy: Curtis D. Wilbur, who had been appointed Secretary of the Navy after Edwin Denby's resignation on March 10, 1924, formally took over responsibility for the operation and conservation of the Naval Petroleum Reserves from the Secretary of the Interior on August 1, 1927.

\section{PROPOSED EXCHANGE OF ELK HILLS AND BUENA VISTA HILLS LEASES}

In March 1928 a bill was introduced in Congress for the conservation, care, custody, protection, and operation of the Naval Petroleum and Oil Shale Reserves. The bill was studied and amended by different committees for nearly 10 years and finally signed into law by President Franklin Roosevelt on June 30, 1.938. The bill authorized the Secretary of the Navy to exchange Navy lands in NPR-2 (Buena Vista Hills) for private lands in NPR-1 (Elk Hills) or to purchase privately owned lands within NPR-1 in order to stop drainage. In case an equitable arrangement could not be agreed upon, the Secretary of the Navy was authorized to acquire private lands in NPR-1 by condemnation.

By 1938 the only owner of private land inside NPR-1 was the Standard Oil Company of California (fig. 23). The railroad lands within the reserve had passed to the Pacific Oil Company in January 1921; on January 1, 1926, the Pacific Oil Company and the Standard Oil Company (California) merged into the Standard Oil Company of California. Prior to the merger a gentleman's agreement existed between Pacific and the Government to refrain from drilling in NPR-1. This arrangement was continued by Standard Oil Company of California. In order to exchange, purchase, or condemn the land belonging to Standard, it was necessary to establish a mutually agreeable value for the property. This proved impossible because many tracts had not been drilled to the Shallow Oil Zone, and none had been explored for deeper production.
UNITI\%ATION DURIN(; WORI.I) WAR II

The advent of World War II found the Navy and Standard at loggerheads. Oil had been discovered in the deeper Stevens Oil Zone with the drilling of well 542$31 \mathrm{~S}$ in early 1941 (fig. 24). The war caused a large increase in demand for petroleum, and Standard notified the Navy that it intended to drill and produce its properties in NPR-1. The Navy countered with a threat of condemnation. The need for cooperative operation of the field became apparent.

The strip leases granted to prevent drainage in 1921 and 1922 were not affected by the Senate investigations and subsequent litigation. These 20-year leases would soon revert to the Navy, at which time only the Navy and Standard would be operating within NPR-1; unitization of all operations would then be feasible, so the Navy and Standard began negotiations toward this end. On October 15, 1942, President Franklin Roosevelt issued Executive Order 9257 extending NPR-1 eastward to include adjacent producing land on the Elk Hills structure. It added about 5,842 acres to NPR-1-about 1,827 acres of public land and 4,015 acres of private land (fig. 25). About 1 month later, November 20, 1942, representatives of the Navy and Standard signed a unit plan contract for the joint operation of the field. The Navy terminated the strip leases in December 1942 and, in addition, purchased the surface rights and the unleased 50-percent mineral interest in the Shallow Oil Zone on the $\mathrm{W}^{1} 1 / 2$ sec. 31 , T. 30 S., R. 25 E. (fig. 25). Standard owned the other 50 percent of this area. This made the Navy and Standard the only operators within NPR-1.

The unit plan contract between the Navy and Standard provided for payment of $\$ 1,748,408.75$ to Standard for surface rights of Standard's land and for the depreciated value of wells and equipment. The respective interests of the Navy and Standard in each oil zone were to be determined by a joint engineering committee. These interests were to be based on the acre-feet of productive zone beneath their respective lands. Revision of the participation percentages were to be made periodically as required by new drilling and adjusted retroactively to November 20,1942. Standard was to take 25 million barrels of oil at a rate of 15,000 barrels per day in compensation for relinquishing control to its oil in the NPR-1. The 25 million barrels were to be deducted from Standard's share of the oil. The Navy was to control the rate of production after Standard obtained the 25 million barrels, although any oil produced except for the purpose of protecting, conserving, maintaining, or testing the reserve had to be authorized by Congress. The reserve was to be operated as a unit by: the Navy, or by a unit operator selected on the basis of competitive bids or by direct negotiation. 


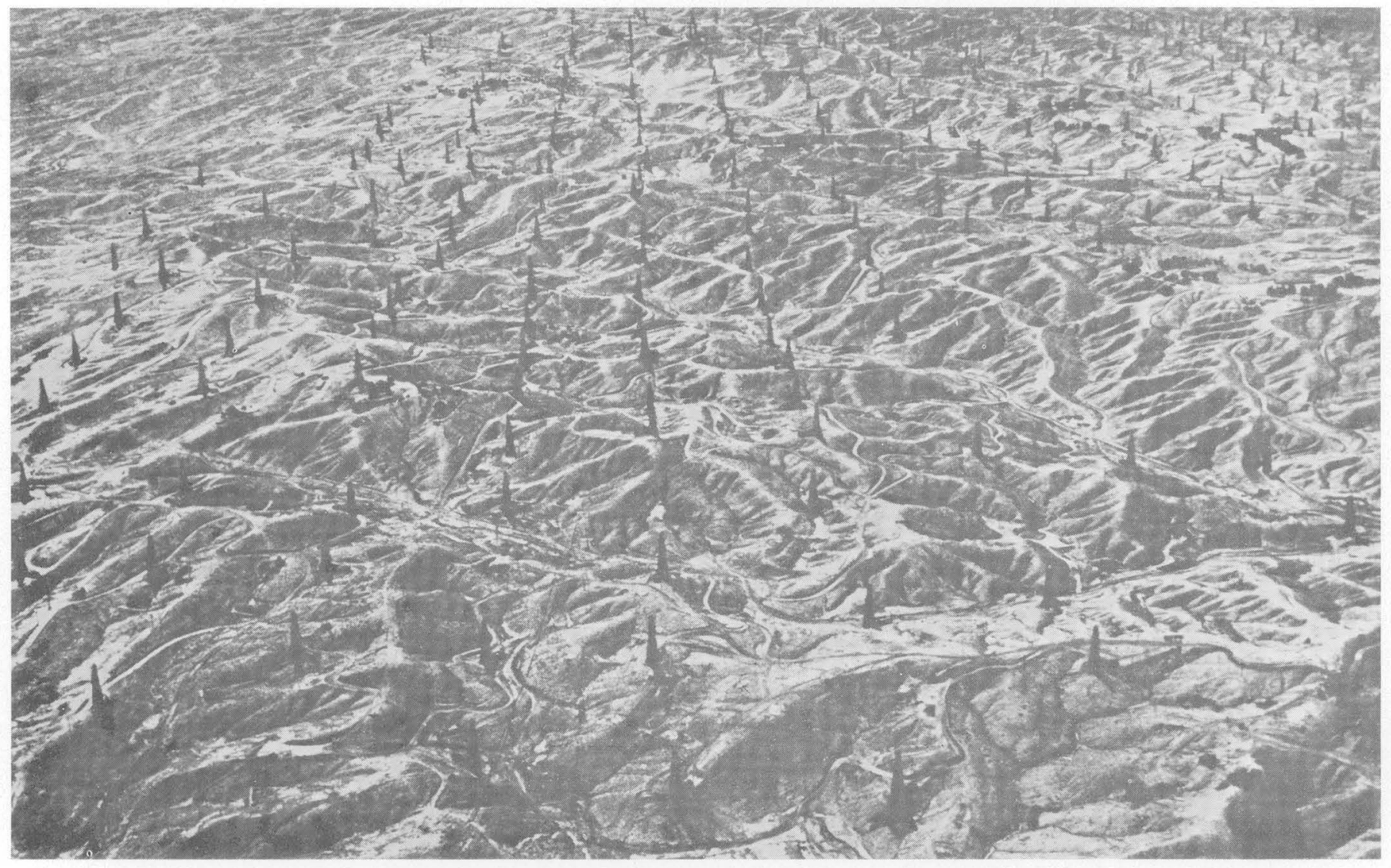

FiguRE 24.-Eastern part of the Elk Hills oil field as developed by June 1941. View west.

The unit plan contract was determined by the Department of Justice to have been signed without authority of law. The contract was rescinded by mutual consent, the land deeds were.returned to Standard, and interim operating agreements were made. A new unit plan contract was agreed upon, received Congressional approval, and was approved by President Roosevelt on June 28,1944 . The new contract was made retroactive to November 20,1942 . At the time the contract was signed, about 225 producing wells were operative within the enlarged boundary of NPR-1, and more than 160 million barrels of oil had been produced.

The provisions of the new contract were much the same as the original; its purpose was to conserve in the ground as much oil as possible. It was envisioned that the field would be shut in except for the production granted Standard and a small amount resulting from testing programs necessary to keep the wells in a state of readiness. However, a shortage of oil developed on the west coast in 1944, and Congress authorized additional development of NPR-1 to increase the rate of production to 65,000 barrels of oil per day. A drilling program was initiated, and 317 wells were drilled to the Shallow Oil Zone before the end of World War II in August 1945. Only four of these wells were dry and abandoned, and the authorized rate of production was met within 8 months. The Government received the income from all production above the 15,000 barrels per day allotted to the Standard Oil Company of California.

POSTWAR ADDITIONS AND STATUS

OF RESERVE IN 1973

Production was reduced after the end of World War II and by May 1946 had declined to 8,000 barrels per day. Development drilling during the next 18 months showed that the boundary of NPR-1 needed to be extended to the west to encompass the entire Elk Hills structure and prevent drainage. This meant the inclusion of a large tract of public land and some additional land belonging to the Standard Oil Company of California. An amendatory and supplemental agreement to the unit plan contract was agreed upon and signed by the Navy and Standard on December 22, 1948. Under the terms of this agreement, certain disputed provisions of the unit plan contract were clarified, and the additional lands were relinquished to NPR-1 by Standard in return for an additional 3.5 million barrels of oil produced from NPR-1. As a result, President Truman issued Executive Order 10052 on April 20, 1949, adding approximately 2,290 acres-2,090 acres of public land 


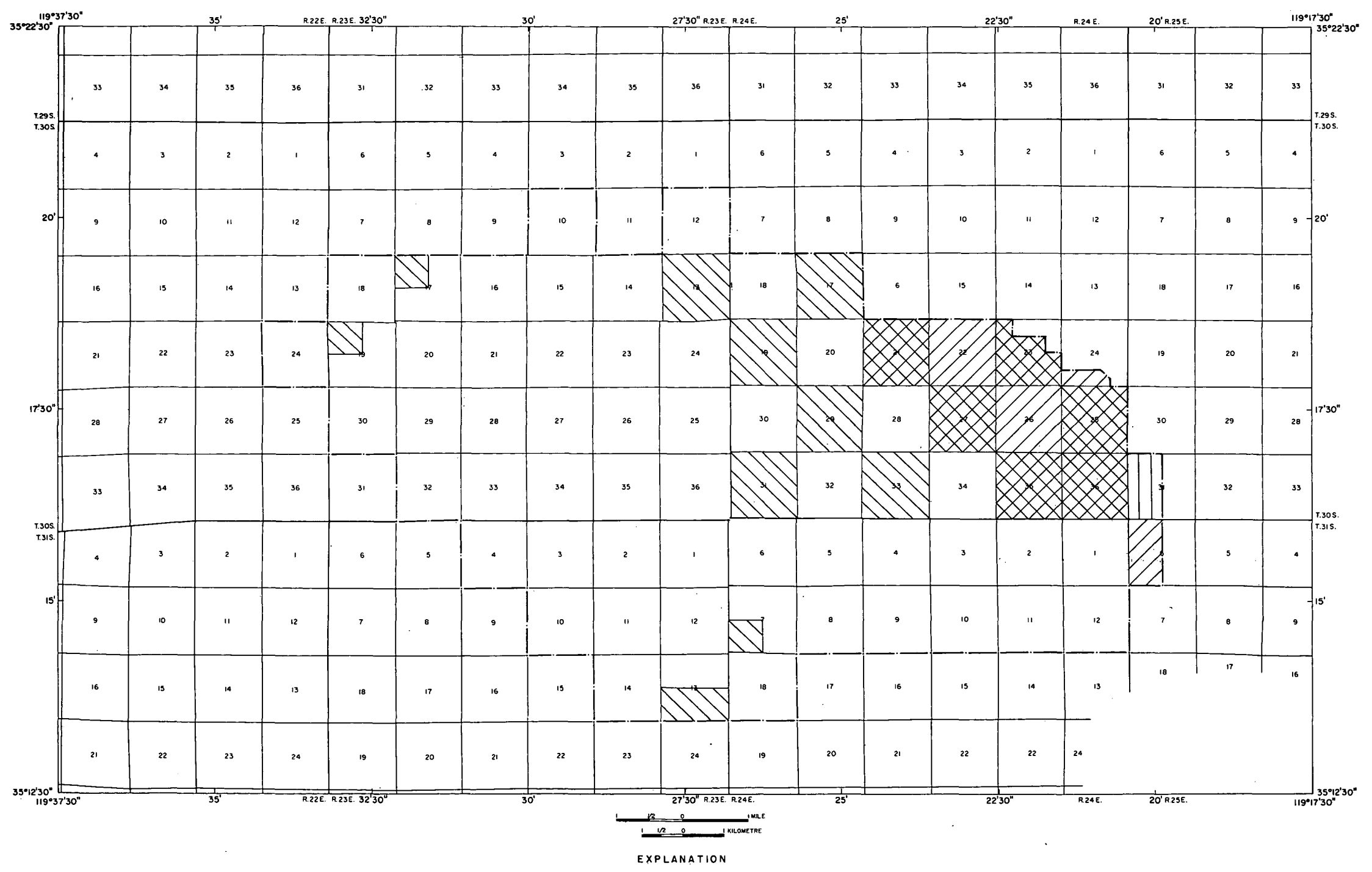

VIA

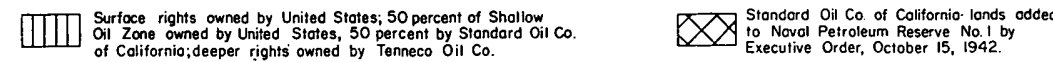

$\square$ Londs owned by United Stotes Government

MIV Lands owned by Stondard oil co. of Coiffornia

- Boundary of Noval Petroleum Reserve No.1

Figure 25.-Area, land ownership, and boundary of Naval Petroleum Reserve No. 1 after Executive Order of October 15, 1942. 
and 200 acres from Standard-to N.PR-1. This addition is the last to date (fig. 26).

NPR-1 as of 1973 included parts of adjacent oil fields as well as Elk Hills, but only the Elk Hills oil field is included in the unit plan contract. Under unit operation, the participating percentage of the Navy is about 80 percent, and that of Standard is about 20 percent. The unit operator, an assignment open to public bidding every 5 years, has been the Standard Oil Company of California since the field was unitized in 1942 .

\section{REGIONAL GEOLOGIC SETTING TECTONIC ELEMENTS}

The central part of California in the vicinity of Elk Hills includes three major structural provinces-the Sierra Nevada, the Central Valley, and the Coast Ranges. These are elongate belts more than 400 miles long and subparallel to the Pacific coastline (fig. 27). The Sierra Nevada, the easternmost province, is basically a block of granitic rocks that has been faulted upward along its east edge and tilted gently to the west. The Coast Ranges, which compose-the westernmost province, are an anticlinorium in which Mesozoic and Cenozoic sedimentary rocks are complexly folded and faulted. The southern part of this province is cut obliquely by the San Andreas fault. Between the Sierra Nevada and the Coast Ranges, lies a tectonic trough known as the Central Valley of California, the north half of which is the Sacramento Valley and the south half the San Joaquin Valley. Extensions at the south end of both the Coast Ranges and Sierra Nevada compose the San Emigdio and Tehachapi Mountains, which together constitute an easterly trending positive element that forms the abrupt south terminus of the Central Valley (fig. 27).

\section{SIERRA NEVADA}

The Sierra Nevada is 50-80 miles wide and extends from the Cascade Range and Modoc Plateau southward more than 400 miles to the Mojave Desert. Most of the southern Sierra Nevada is composed of granitic rocks that are part of the Sierra Nevada batholith. During Cretaceous and Cenozoic time, a huge block in the present Sierra Nevada and Central Valley province was broken along its east side by the Sierra Nevada fault system and tilted westward. The eastern part was elevated to form the Sierra Nevada, and the western part tipped downward to form the Central Valley (Dibblee, 1955, p. 26). The westward-dipping granitic surface of the block is overlapped by sedimentary rocks deposited in the Central Valley (Bateman and Wahrhaftig, 1966, p. 107-169).

\section{COAST RANGES}

The Coast Ranges extend more than 550 miles along the California coastline from the Oregon border southward to Point Conception and attain a maximum width of about 70 miles. Along most of their length, they form the west boundary of the Central Valley of California. The Coast Ranges consist of many separate ranges, coalescing mountain masses, and structural valleys.

The entire province is structurally complex. The core areas of the ranges consist of two entirely different kinds of rocks, one being a Jurassic and Cretaceous graywacke sequence-the Franciscan Formation-and the other consisting of older metamorphic rocks-the Sur Series of former usage-that have been invaded by granitic intrusions of Cretaceous age. The two seemingly unrelated core complexes lie in proximity but are everywhere separated by large faults. A thick section of late Mesozoic and Cenozoic sedimentary rocks surrounds the exposed core areas and covers large parts of the province. The entire sequence of rocks has been subjected to recurrent tectonic movement. Folds, thrust faults, steep reverse faults, and strike-slip faults have developed as a result of compressional deformation, some of which is continuing at the present time (Page, 1966, p. 255).

Barbat (1971, p. 1557) in his discussion of the megatectonics of the Coast Ranges summarized the basement history:

It is concluded that a large prism of sediments was deposited across the boundary of the Pacific Ocean and North America continent at the site of the present Coast Ranges in Late Jurassic to Late Cretaceous time. During the Coast Range Orogeny, Late Cretaceous to midEocene, the prism was bisected by a gentle easterly dipping thrust fault, the sediment segment of the Coast Ranges thrust fault. Sedimentation during the Coast Range Orogeny was progressively confined to the east due to shoaling and emergence of the Coast Ranges; however, there was no mountain building, no volcanism, and no plutonism-nor were island arcs and trenches formed.

The sediment segment of the Coast Ranges thrust separates the prism of sediments into two tectofacies. The hanging-wall block contains the relatively undisturbed Great Valley sequence. The footwall block contains the tectonically jumbled Franciscan. The Great Valley sequence is essentially unmetamorphosed except by burial metamorphism. The Franciscan is mildly to intensely metamorphosed.

According to Barbat (1971, fig. 1), the Coast Ranges thrust fault, along which the Great Valley sequence was thrust over the Franciscan sequence prior to late Eocene time, extends beneath the western strip of the Great Central Valley from the Klamath Mountains of northern California to the south end of the San Joaquin Valley, where it is cut by the subsequent San Andreas fault. The only well in the vicinity of Elk Hills that reached rocks involved in this westward thrust is the CLA 67-29T well in the North Coles Levee field, which drilled into gold-bearing (Simonson, 1958, p. 104, fig. 5) green metamorphic rock of Mesozoic (Jurassic?) age at a 


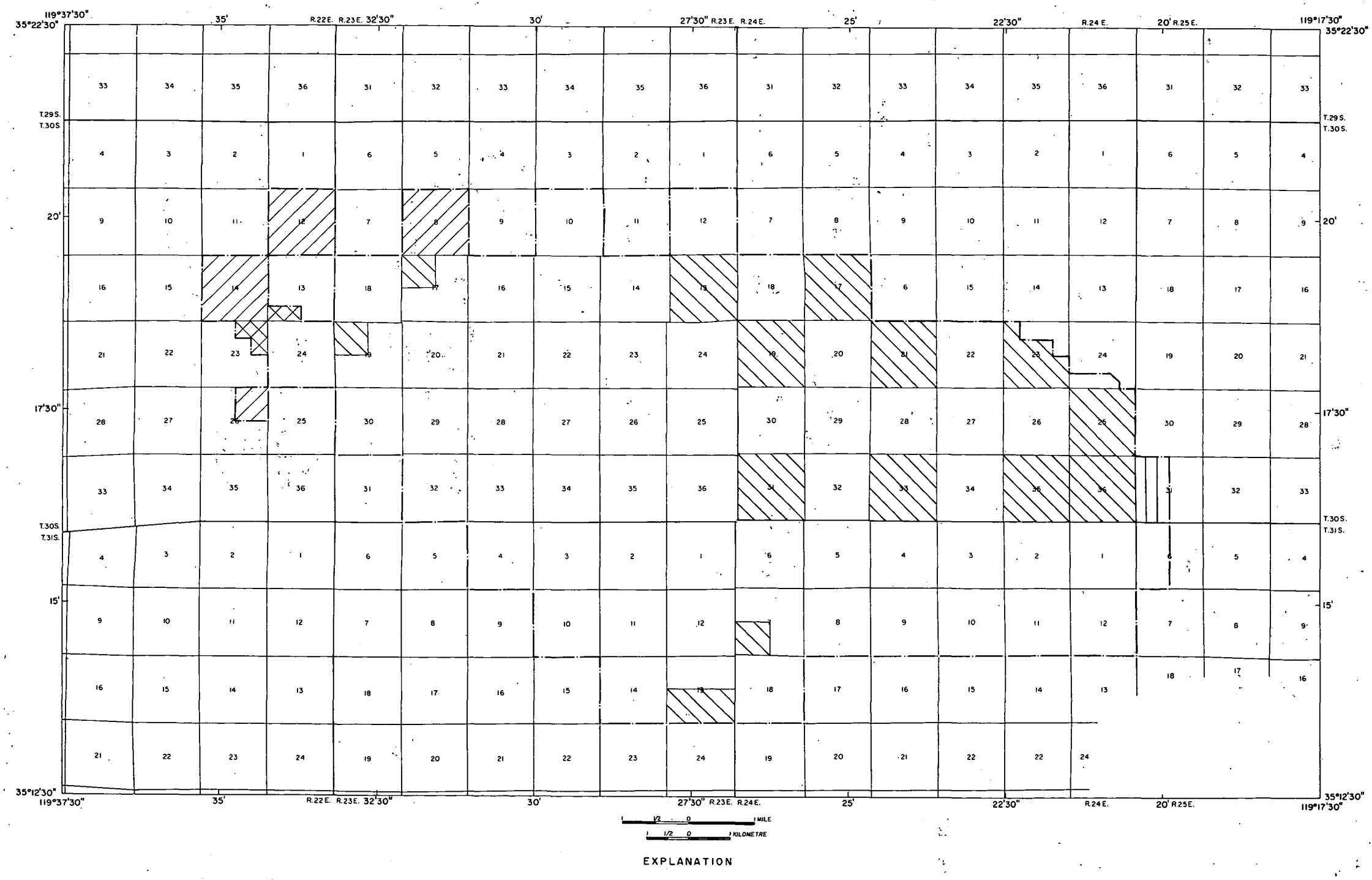

ZIד

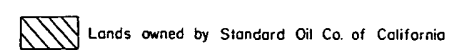

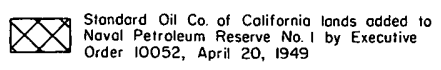

7 Londs, Domed by United Strates Government
11]

$\because \quad:$

FIGURE 26.-Present area, land ownership, and boundary of Naval Petroleum Reserve No. 1 in 1973. 


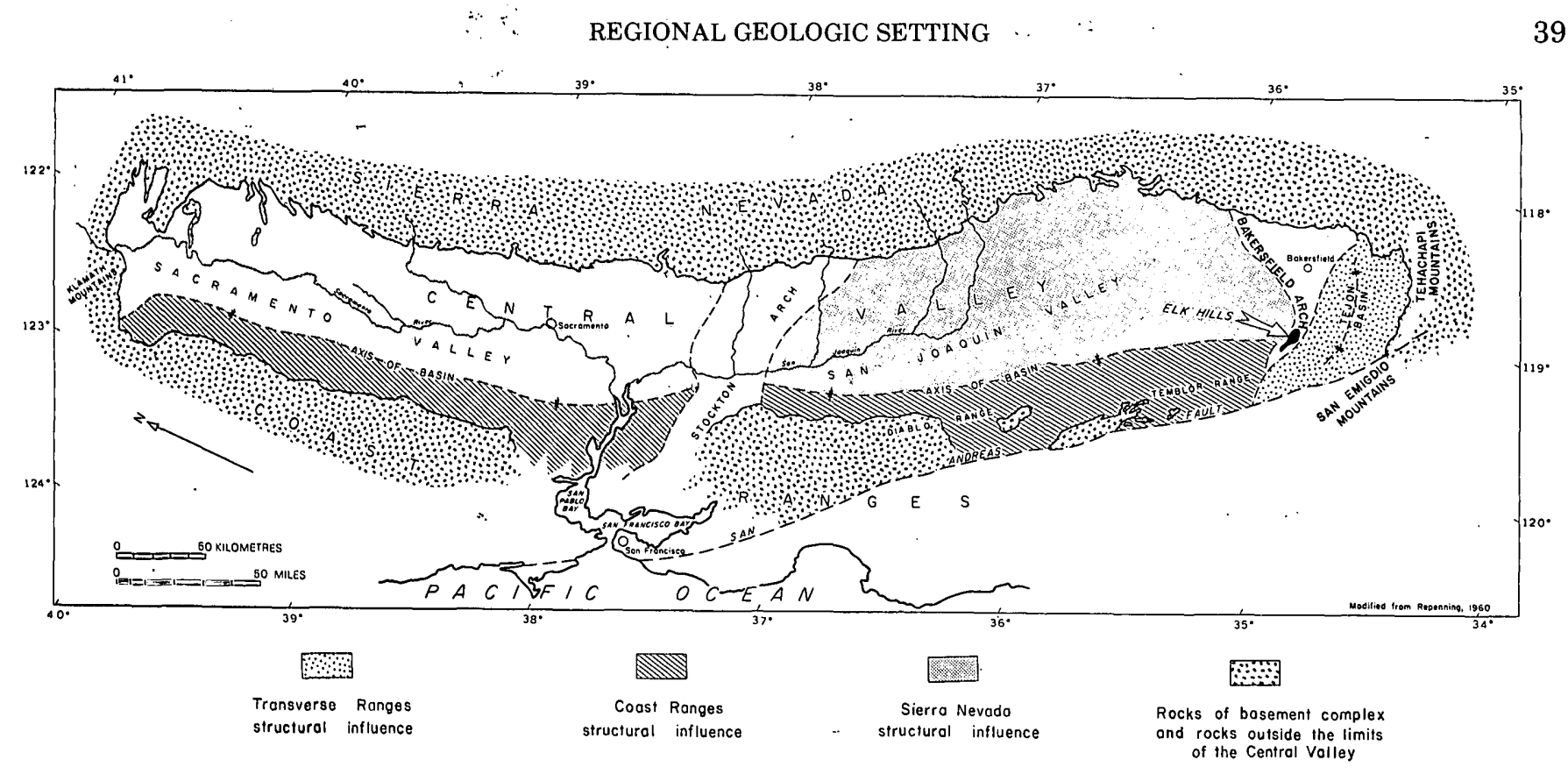

FigURE 27.-Location of the Elk Hills oil field in relation to regional tectonic elements.

depth of almost 18,000 feet. In the opinion of Barbat (written commun., Dec. 19, 1972), the green metamorphic rock "may be a green schist of the Sierran basement type that underlies the Great Valley, and ***:occurs in the hanging-wall block of the Coast Ranges thrust fault." With this interpretation, the trace of his Coastal Ranges thrust fault (Barbat, 1971, fig. 1) passes between the Elk Hills and North Coles Levee oil fields.

The dominant structural feature of the southern Coast Ranges is the northwest-trending San Andreas fault, the largest and most active crustal break in California. This fault lies 12 miles west of Elk Hills beyond the Temblor Range of the Coast Ranges and the Tejon basin (fig. 27). The San Andreas fault together with the east-northeast-trending Garlock fault (not shown in fig. 27), which intersects it in the San Emigdio Mountains, form the San Andreas strain system. The faults have been active for approximately 100 million years, and structural features developed along the faults during this period are compatible with a strain system of north-south shortening and east-west relative extension according to Hill (1971, p. 3). Barbat (1971, p. 1549) estimated a right-lateral slip of 310 miles along the San Andreas fault; Hill (1971, p. 4-5) proposed a figure of 450 miles. Movement of either magnitude would indicate the San Andreas fault was undoubtedly a powerful force in the formation of the southern Coast Ranges and adjacent structures along the west side of the San Joaquin Valley. Barbat (1971, p. 1549) noted that folds and faults are numerous in the Coast Ranges, with the larger folds being present east of the San Andreas fault. He noted also that near the south end of the Great Valley where the crystalline rocks have been greatly depressed to form the "Dark Hole" (Tejon basin), large high-amplitide folds are present, the more westerly of which have axes oriented at acute angles of $10^{\circ}$ to about $30^{\circ}$ to the San Andreas fault. One of these westerly folds is Elk Hills, whose axis forms a $32^{\circ}$ angle with the San Andreas fault. Moody and Hill (1956, p. 1215) described the Cymric anticline at the northwest end of the Elk Hills-Railroad Gap structural trend (fig. 28) as a drag fold produced by wrench faulting along the San Andreas fault. Later Moody (1973, p. 454) ascribed the same origin to Elk Hills.

The Temblor Range (fig. 27) trends in a slightly more easterly direction than the Coast Ranges as a whole. Similarly, individual folds composing the Temblor Range have a more easterly trend than the range itself. These obliquely trending folds are larger and more numerous southward and at the south end of the Temblor Range exhibit a complicated system of easterly trending folds and faults that form the San Emigdio Mountains (Pack, 1920, p. 54-56).

\section{CENTRAL VALLEY}

The Central Valley of California, sometimes called the Great Valley of California, lies between the Sierra Nevada and the Coast Ranges (fig. 27). It extends from the Klamath Mountains southward about 450 miles to the San Emigdio and Tehachapi Mountains and is 40-50 miles wide in most places (Repenning, 1960, p. 1; Hackel, 1966, p. 217).

The Central Valley is an elongate structural trough formed by the depressed western part of the huge relatively rigid Sierra Nevada fault block. The block was tilted by faults on its east side, and about 75,000 cubic 


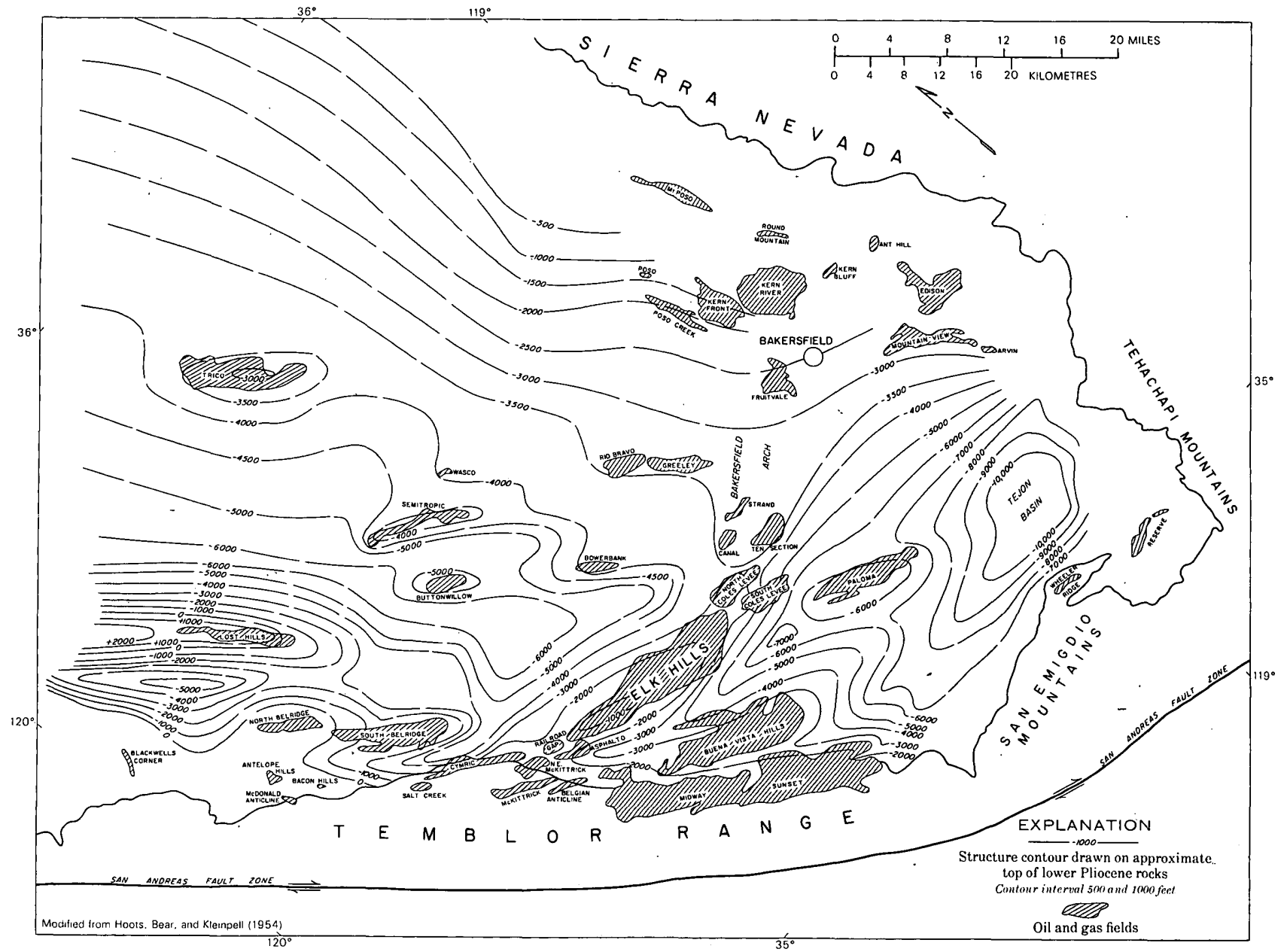

FIGURE 28.-Regional structure in relation to oil and gas fields of southern San Joaquin Valley.

miles of sediments (Hobson, 1951, p. 209; Kilkenny, 1951 , p. 215) was eroded from it, carried westward, and deposited during Cretaceous and Cenozoic time in the sinking Central Valley. Westerly tilting caused the most rapid subsidence on the west side of the valley, and the basement complex is progressively more deeply buried from east to west (Dibblee, 1955, p. 26). The resulting basin is asymmetric, and the axis is near and parallel to its west border. The Central Valley now has an almost flat alluvial floor, most of which is only a few hundred feet or less above sea level, broken by scattered hills and ridges that commonly refiect local anticlines. The alluvial fill conceals the axis and much of the flanks of this large structural trough (Hoots and others, 1954, p. 113).

The gently sloping floor on the east flank of the basin is a continuation of the Sierra Nevada granitic surface. Beds deposited in this part of the basin, known as the Sierra slope, have a prevailing gentle westerly dip and have been subjected to only minor folding and faulting. The west flank of the basin, known as the "folded trench," has been complexly folded and faulted as a result of movement in the adjoining tectonically active Coast Ranges province. This area is mostly floored by thick sedimentary rocks of probable Jurassic and Cretaceous age referred to the Franciscan Formation Irwin, 1957, p. 2284-2297).

A positive transverse feature called the Stockton arch bisects the Central Valley. The area north of the Stockton arch is drained by the Sacramento River and is called the Sacramento Valley. The southern part is drained mostly by the San Joaquin River and is called the San Joaquin Valley. In the southern part of the San Joaquin Valley near Bakersfield, another positive transverse feature called the Bakersfield arch crosses the basin and forms the north limit for a small deep basin located at the extreme south end of the Central Valley structural trough (fig. 27). This small basin has been called the "southern basin" (Repenning, 1960, p. 50), the "Maricopa basin" (Reed and Hollister, 1936, p. 48), the "Tejon basin" (Hackel, 1966, p. 236), and the "Dark Hole" (Barbat, 1971, p. 1542). It is shown as the Tejon basin in figure 27 of this report. Although the Tejon basin is a part of the San Joaquin Valley deposi- 
tional basin, it is a separate structural entity with distinct characteristics of its own. The major folds in the basin have a predominant eastward trend that closely parallels the transverse trend of the San Emigdio and Tehachapi Mountains. The Tejon basin shows structural gradation similar to that of the San Emigdio and Tehachapi Mountains. The western part has been folded and faulted by compression, whereas the eastern part has been influenced largely by vertical movements.

The site of maximum deposition of sediments moved southward in the Central Valley basin with the passage of geologic time. The Sacramento Valley, north of the Stockton arch, contains deposits primarily of Cretaceous age. The San Joaquin Valley between the Stockton arch and the Bakersfield arch contains a thick section of sedimentary rocks of early and middle Cenozoic age, and the Tejon basin south of the Bakersfield arch contains one of the thickest sections of late Cenozoic rocks known in California (Reed and Hollister, 1936, p. 48, 70).

The Bakersfield arch protrudes westward from the Sierra Nevada as a broad basement high that plunges gently to the west beneath the San Joaquin Valley. The broad arch narrows rather abruptly along the west side of the Rio Bravo and Greely oil fields, possibly reflecting basement faulting. The narrowed arch, as outlined by the -3500 -foot contour on figure 28 , extends westward through the Strand, Canal, and Ten Section oil fields. It appears to be alined with the Elk Hills anticlinal trend and, according to Bandy and Arnal (1969, p. 796), was a positive belt as early as the Oligocene. The sedimentary rocks on the Bakersfield arch are deformed by broad open folds and normal faults that are probably the result of vertical movements in the Sierra Nevada (Hoots and others, 1954, pl. 5).

The structural pattern of the southwest flank of the Central Valley has been determined by the development of the adjacent Temblor Range, which in turn is subject to the San Andreas strain system. The Temblor Range is composed of a series of anticlinal folds that diverge from the south-trending Coast Ranges and plunge southeastward into the valley. Some folds, one of which is the Elk Hills anticline, are prominent structural features that extend several miles into the basin.

The south end of the San Joaquin Valley is enclosed by a series of mountains that form a broad east-west arc joining the Sierra Nevada to the Coast Ranges. The eastern part of the arc is formed by the Tehachapi Mountains-a topographic but not structural extension of the Sierra Nevada; the western part of the arc is formed by the San Emigdio Mountains-an extension of the Temblor Range.

\section{STRATIGRAPHIC SEQUENCE}

Tertiary and Quaternary deposits, as much as 17,000 feet thick, underlie Elk Hills and adjacent oil fields and are exposed along the Temblor Range, 15-25 miles northwest of Elk Hills. The areal distribution and structure of these rocks are shown on geologic maps of the Temblor Range compiled by Dibblee (1968, 1969, 1972). Rocks in the Temblor Range dip eastward under the San Joaquin Valley to reappear with a more continental aspect on the flanks of the Sierra Nevada and Tehachapi Mountains. The regional stratigraphic relations through Elk Hills are well illustrated by a correlation section published by the Pacific Section, American Association of Petroleum Geologists (Church and others, 1957).

Only rocks of Pliocene and Pleistocene age (Tulare Formation) are exposed at Elk Hills (pl. 3), but more than 1,000 wells have been drilled there to oil and gas reservoirs in the upper part of the Monterey Shale of Miocene age and in the Etchegoin and San Joaquin Formations of Pliocene age. Fewer than 10 wells have been drilled through the Monterey Shale, and consequently geologic data on the older rocks are sparse. The stratigraphic units known to underlie Elk Hills and adjacent oil fields and the approximate range of thickness for each unit are shown in table 3.

TABLE 3.-Stratigraphic units and their approximate thickness in Elk Hills and vicinity

\begin{tabular}{|c|c|}
\hline Stratigraphic unit & $\begin{array}{l}\text { Thickness } \\
\text { (ft) }\end{array}$ \\
\hline $\begin{array}{l}\text { Rocks of Pliocene and Pleistocene age: } \\
\text { Tulare Formation }\end{array}$ & $600-2,200$ \\
\hline $\begin{array}{l}\text { Kocks or Plocene age: } \\
\text { San Joaquin Formation }\end{array}$ & $1,200-2,100$ \\
\hline Etchegoin Formation & $1,700-3,500$ \\
\hline Carman Sandstone Member & $900-2,000$ \\
\hline Tupman Shale Member & $750-2,000$ \\
\hline \multicolumn{2}{|l|}{ Rocks of middle and late Miocene age: } \\
\hline Reef Ridge Shale & $200-1,150$ \\
\hline Monterey Shale & $2,100-4,100$ \\
\hline Elk Hills Shale Member & $1,800-3,300$ \\
\hline McDonald shale of local usage & $80-600$ \\
\hline Gould and Devilwater Shale Members & $100-655$ \\
\hline \multicolumn{2}{|l|}{ Rocks of Oligocene and early Miocene age: } \\
\hline Temblor Formation & $2,900-4,100$ \\
\hline Media Shale Member & $150-560$ \\
\hline Carneros Sandstone Member & $0-950$ \\
\hline Santos Shale Member & $1,340-3,090$ \\
\hline Wy'gal Sandstone Member & 450 \\
\hline Cymric Shale Member & 300 \\
\hline \multicolumn{2}{|l|}{ Rocks of Oligocene age: } \\
\hline Wagonwheel Formation & $250-700$ \\
\hline Rocks of late Eocene age: & \\
\hline Kreyenhagen Formation & $2,300-2,900+$ \\
\hline Welcome Shale Member & $900-1,950+$ \\
\hline Point of Rocks Sandstone Member & $400-2,000+$ \\
\hline $\begin{array}{l}\text { Gredal Shale Member } \\
\text { Rocks of Mesozoic age. }\end{array}$ & Not penetrated \\
\hline
\end{tabular}

\section{STRUCTURAL GEOLOGY}

\section{STRUCTURE OF SURFACE ROCKS}

In the southwestern San Joaquin Valley, Arnold and Johnson (1910, p. 96, 99, pl. 1) described and mapped two surface structures: a "Temblor anticline," which they traced from the center of the Temblor Range 
northwest of Elk Hills southeastward through Frazer Spring to the McKittrick area several miles west of Elk Hills and a "Gould anticline," which is mapped near the axis of the Temblor Range northwest of Elk Hills to the Gould Hill area and thence southeastward to what is now known as the Railroad Gap structure immediately west of Elk Hills. The Elk Hills folds are clearly related to the Railroad Gap anticline as is shown by the contours on the extreme west end of plate 3 . A geologic map by Pack (1920, pl. II) indicates a primary fold through Elk Hills directly into the Railroad Gap-McKittrick area. The Bakersfield sheet of the geologic map of California (California Division of Mines and Geology, 1965) does not show structural axes, but the outcrop pattern of the Tulare Formation indicates a northwestward link between the Elk Hills and the Temblor Range.

The Tulare Formation, which lies at the surface at Elk Hills, has been folded into a large compound anticline that has about 400 feet of closure. It consists of two subsidiary en echelon anticlines with broad tops and steep flanks whose dips are steepest along the south edge. These folds, referred to here as the Western and Eastern anticlines, were mapped but not named by Woodring, Roundy, and Farnsworth (1932, pl. 1). Their map with minor modifications is shown on plate 3 and used in the following discussion of the surface structure.

The Western anticline, known as the $29 \mathrm{R}$ structure by the unit operator, is a relatively simple fold that trends southeastward and connects across a flat saddle to the less prominient Eastern anticline offset en echelon to the northeast. Its crest is about 150 feet structurally higher than that of the Eastern anticline, and the apex approximately coincides with the highest topographic point of Elk Hills, 1,551 feet above mean sea level. Northward the Tulare Formation dips about $3^{\circ}$ rather uniformly from the crest of the western anticline to the outer periphery of Elk Hills, where the dip is somewhat steeper. The southwest limb dips slightly more than $4^{\circ}$ near the crest, but at the periphery it is considerably steeper. The northeast flank is much wider than the southwest one because of the more gentle dip and because the San Joaquin Valley floor to the north is lower than that of Buena Vista Valley to the south. The Western anticline plunges from the structurally highest point to the west-northwest and is structurally about 660 feet lower where it terminates in a very sharp nose characteristic of folds in the narrow belt of foothills farther west (Woodring and others, 1932, p. 42). To the east the anticline plunges 150 feet structurally into the saddle that connects the Western anticline with the en echelon Eastern anticline. No faults have been observed in the surface rocks of the Western anticline.

The Eastern anticline, known as the $31 \mathrm{~S}$ structure by the unit operator, is both structurally and topographically less distinct than the Western anticline. Its crest is marked by four small domes with closures of 25-50. feet extending in a line southeastward subparallel to the axis of the Western anticline. The axis of the Eastern anticline curves in its eastern part from southeastward to slightly north of east and forms the crest of a broad structural nose to the east limits of Elk Hills. The Eastern anticline is slightly asymmetrical, the northeast limb being steeper than the southwest one, and also steeper than the northeast limb of the Western anticline. The northeast flank of the Eastern anticline is cut by four normal faults that bound a series of terracelike structural steps or noses on the northeast flank. The eastward plunge into the San Joaquin Valley is about $2^{\circ}$; the termination of the fold is broad and blunt.

Four normal faults, numbered 1-4 from west to east, were mapped on the Eastern anticline by Woodring, Roundy, and Farnsworth (1932, p. 42) on the basis of the distribution of buff mudstone at the base of the upper part of the Tulare Formation. The buff mudstone is faulted against olive-gray mudstones of the lower part of the formation, and the faults are downthrown on the northwest side. The presence of several faults in the shallow oil-bearing beds was known long before the surface faults were found. The faults have no topographic expression, and the stratigraphic sequence of the Tulare Formation is a monotonous succession of beds having similar color and lithology that make the detection of faults at the surface very difficult. It seems probable that many of the numerous subsurface faults shown on plate 4 of this report reach the surface, although only a few have been mapped there.

According to Woodring, Roundy, and Farnsworth (1932, p. 42-43), the normal faults are downthrown to the northwest; strike northeastward, dip at angles of $55^{\circ}-66^{\circ}$ northwestward, and have displacements of 35-160 feet. The fault displacements recorded by Woodring, Roundy, and Farnsworth (1932, p. 43) for faults 2,3 , and 4 are 105,115 , and 50 feet, respectively. These figures must be estimates because no marker beds are exposed so that stratigraphic positions can be compared across the faults. Electric logs of wells drilled after 1932 show displacements of 314 and 200 feet along faults 2 and 3 at depths of less than 800 feet. These data along with the known increase of dip of the fault planes toward the surface suggest that the estimates of the fault displacements at the surface are too low.

In addition to the normal faults, Woodring, Roundy, and Farnsworth $(1932$, p. 44, 45) noted several small thrust faults. These cut overturned folds along a stream course on the north slope of Elk Hills, and they are believed to have been produced by minor slumping.

"Earthquake cracks" were mapped and described by Woodring, Roundy, and Farnsworth (1932, pl. 1, p. 11- 
12). The cracks are shallow trenches a few feet deep and 10-15 feet wide. They are found along and parallel to the extreme north flank, bending to the southwest at the west end of the Elk Hills structure. There is no apparent displacement along the trenches, which are most easily seen on aerial photographs. Woodring, Roundy, and Farnsworth (1932, p. 12) described the trenches. as similar to cracks formed during the San Francisco earthquake of 1906 that resulted from movement along the San Andreas fault. The trenches are all in the same stage of obliteration and apparently were formed contemporaneously. Their trend is approximately perpendicular to the northeast-trending normal faults mapped at the surface except where the trenches curve to the southwest at the west end of Elk Hills. The geologic map of California, Bakersfield sheet (California Division of Mines and Geology, 1965) shows the trenches as faults. Well control in the vicinity of the trenches is meager; logs of the few wells drilled do not indicate faults in the subsurface.

Several very narrow sinuous anticlines of low amplitide appear on the flanks of the Elk Hills structure-one on the northwest flank and five along the south flank (pl. 3). The fold on the northwest flank extends as a narrow spur 11/2 miles northwestward from a point midway down the flank. Its axis is about parallel to those of the major folds, and closure amounts to about 50 feet. Along the south flank the westernmost flexure, about 2 miles long, trends parallel to the major folds and has closure of more than 200 feet. Both this fold and the fold on the northwest flank coincide with narrow ridges that are readily apparent on topographic maps and aerial photographs. (See frontispiece.) The other four folds along the south flank are not clearly expressed by the topography. The second fold eastward along the south flank is about 1 mile long; its closure possibly amounts to 100 feet, and its axis is parallel to the trend of the major folds. The third fold along the south flank is about one-half mile to the east. It is only one-fourth mile long, probably has less than 25 feet of closure, and trends the same as its neighbor to the west. The fourth fold in line to the east has a sinuous axis about 3 miles long that trends more easterly than the axes of the other folds. The amount of closure is uncertain but is probably more than 100 feet. The fifth and easternmost of the minor anticlines along the south flank is about one-third mile long, has a possible closure of 25-50 feet, and is oriented parallel to the trend of the major folds and to the first three of the south-flank folds described. Dips on the flanks of the anticlines range from $20^{\circ}$ to $90^{\circ}$ (Woodring and others, 1932, p. 44). As shown on the geologic map (pl. 3), the small anticlines have undergone different amounts of erosion. The least eroded is the one on the north slope at the west end of the hills. It is a flat-topped asymmetric fold with steeper dips on the north flank.
The most deeply eroded anticline is the westernmost one along the south edge of Elk Hills. Several hundred feet of the upper part of the Tulare Formation have been eroded from its crest exposing the lower part of the Tulare.

The origin of the minor folds is uncertain. The westernmost of the south-flank folds is opposite a fold of similar size and orientation in the Buena Vista Hills to the south; the two folds may be drag folds, as suggested by $\mathrm{H}$. W. Hoots, caused by slipping and buckling as the Elk Hills and Buena Vista Hills were raised and the intervening syncline deepened (Woodring and others, 1932, p. 45). Woodring, Roundy, and Farnsworth (1932, p. 45) concluded that "the main broad folds and also the minor.ones are probably due to rotational stress set up by horizontal movements in the basement rocks." In areas along the south flank where well data are available, the folds are not reflected in the shallow subsurface beds (pl. 4), which suggests to us that the folds may have been caused by slumping.

\section{STRUCTURE OF SUBSURFACE ROCKS}

\section{UPPER MIOCENE ROCKS}

The structure of the upper Miocene rocks, buried to depths below 4,000 feet at Elk Hills, is shown by plate 4 . Plate 4 depicts the structure at the top of the Elk Hills Shale Member, the uppermost member of the Monterey Shale; the structure at the top of the Reef Ridge Shale, the uppermost formation of the Miocene; and the structure at the Scalez horizon in the lower San Joaquin Formation of the Pliocene. The contours are based on approximately 400 wells.

The structure of upper Miocene rocks in the Elk Hills oil field consists of two large en echelon anticlinal folds, the Western and Eastern anticlines. Although broadly similar to the structure at the shallower Scalez horizon and at the surface, the folds are sharper and much more distinctly separated at depth. An increase in amplitude of the folds with depth is apparent even between the Reef Ridge Shale (pl. 4) and the Elk Hills Shale Member (pl. 4), which are within a few hundred feet of each other stratigraphically.

In upper Miocene rocks the Western anticline is a narrow linear fold, approximately 6 miles long and less than 1 mile wide, with about 750 feet of closure on both the Elk Hills and Reef Ridge Shales. The crest, which trends southeastward, is interrupted by four domes with separate closures of 250-500 feet. Two small anticlines, mostly outside NPR-1, lie parallel to the Western anticline near its west end. One is the Railroad Gap anticline in the southwest corner of sec. 14Z; the other is the Flickinger anticline in sec. 25Z. Both trapped oil in Miocene reservoirs that are part of the Railroad Gap and Asphalto oil fields, respectively. 
The Eastern anticline is an open fold about 7 miles long and less than 2 miles wide in the upper Miocene rocks. Its axis curves from southeastward to slightly north of east along the south line of sec. 32S. From there a broad nose, as much as 1 mile wide, protrudes eastward. In the area of secs. $36 \mathrm{~S}$ and $1 \mathrm{G}$, the hroad nose is split in two by a shallow syncline, and the two subsidiary noses diverge from each other toward the North Coles Levee and South Coles Levee oil fields, respectively. The reversal of dip at the top of the Elk Hills Shale Member between the Elk Hills and North Coles Levee fields is less than 130 feet and that between the Elk Hills and South Coles Levee fields is more than 300 feet. The Eastern anticline has a closure of about 2,300 feet at the top of the Elk Hills Shale Member but only about 1,750 feet at the Reef Ridge Shale horizon. This 550-foot difference of closure between these horizons on the Eastern anticline contrasts with the almost equal closures at the same horizons on the Western anticline.

Faulting appears to be of only minor importance in the upper Miocene rocks along the crestal part of the Elk Hills anticlinal trend. Two relatively small normal faults with a maximum throw of 280 feet appear to cut the Reef Ridge Shale and the top of the Elk Hills Shale Member in secs. 26R and 30R (pl. 4). Both faults strike northeasterly and are downthrown to the northwest. Another fault cuts the top of the Reef Ridge Shale in sec. $34 \mathrm{~S}$ but does not appear to reach the Elk Hills Shale Member. This fault trends north-northeast and is downthrown to the west. The faults do not appear to reach the surface or to connect with faults that cut the Scalez horizon. (See pl. 4). Because they apparently are narrowly confined stratigraphically, these faults probably had little effect on oil and gas accumulation.

\section{PLIOCENE ROCKS}

The subsurface structure of the middle Pliocene rocks of the Elk Hills oil field and adjacent areas is shown by structure contours on the Scalez horizon on plate 4.

More than 900 wells have been correlated to provide the control for the structure map. The contour intervals are 100 feet where control is plentiful and 500 feet where control is sparse. In areas of dense drilling, the strike and dip of faults were determined by contouring.

The Elk Hills anticlinal structure is about 10 miles long and less than 3 miles wide and has about 750 feet of closure at the Scalez horizon. The two en echelon anticlines so prominent at upper Miocene horizons are much less distinct in the Pliocene rocks. The Western anticline is about 5 miles long and no more than 1 mile wide and has a closure of less than 300 feet. The fold is flat topped with two elongate domes at the crest. The Flickinger anticline in sec. 25Z, so distinct in upper Miocene rocks, is represented on plate 4 by a long structural nose. Some closure may be found by additional drilling. The Railroad Gap anticline in sec. $14 \mathrm{Z}$ adjacent to the northwest end of the Western anticline exhibits about 100 feet of closure on the Scalez horizon.

The Eastern anticline is poorly defined in Pliocene rocks because of numerous normal faults. The anticline l:as closures of 100-200 feet against faults and around some small domes. A long nose protruding eastward from the structurally highest part of the anticline is faulted at many places but seems to extend without any reversal of its eastward plunge into the North and South Coles Levee fields.

At least 20 normal faults strike northeastward across the axis of the anticline and exhibit dips from $45^{\circ}$ to $55^{\circ}$. The vertical displacements measured range from 35 to 340 feet. Most faults are downthrown on the northwest side; however, five are downthrown to the southeast. These include the westernmost fault in secs. $25 \mathrm{R}$ and 26R, a fault in sec. $31 \mathrm{~S}$, one in secs. $8 \mathrm{G}$ and $9 \mathrm{G}$, and one that extends across secs. $1 \mathrm{G}$ and $2 \mathrm{G}$ into secs. $29 \mathrm{~T}$, 31T, and $32 \mathrm{~T}$ in the North Coles Levee field.

The faults do not seem to be present in the Miocene rocks. Dips of the fault surfaces decrease with depth and approach horizontal at the top of the Reef Ridge Shale of Miocene age. Four faults in Pliocene beds, marked SF $-1,-2,-3$, and -4 on plate 4 connect with the surface faults mapped by Woodring, Roundy, and Farnsworth (1932, pl. 1, nos. 1-4). Other faults recognized at the Scalez horizon probably reach the surface, but if so, they lack expression in the nonresistant monotonous succession of sandstone, siltstone, and mudstone of the outcropping Tulare Formation.

Several authors suggest thrust faults (Hackel, 1966, p. 236; Wells, 1952, p. 243, 245; Willis, 1927, p. 42) and normal faults of regional scale (Clark, 1929, p. 210, 218) at Elk Hills. Others, however, disagree. Callaway $(1968$, p. 23) stated that "****in the vicinity of *** Elk Hills, faulting is unimportant to nonexistent." According to Gester and Galloway (1933, p. 1165), typical structures along the east margin of the Coast Ranges. bordering the San Joaquin Valley ordinarily commence as faults in the higher part of the Coast Ranges, diverge eastward from the general trend of the Coast Ranges, and decrease in intensity of movement as the valley is approached, and folds in large measure replace the faulting. Pack (1920, p. 57), writing of the Temblor Range, stated "faults are rare in the east flank of the range near its south end." The present work supports the view that thrust faulting and normal faulting on a regional scale are unimportant in upper Miocene and younger rocks at Elk Hills.

\section{STRUCTURAL RELATIONS}

Structural relations at Elk Hills are shown by four 
structure sections (pl. 5) along the lines indicated in figure 29. Wells shown on these sections are the same as those used in another part of the report to illustrate stratigraphic relations, except that structure section $\mathrm{AE}^{\prime}$ (pl. 5) stops in sec. 35S in eastern Elk Hills. Structure section $\mathrm{AE}^{\prime}$ could not be carried farther because of the lack of deep wells. Section GH (pl. 5) crosses the Western anticline approximately normal to its southeastward axial trend. Section KL (pl. 5) extends northward across the highest part of the Eastern anticline. Section MN (pl. 5) trends northward across the long structural nose of the Eastern anticline.

\section{FAULT SYSTEM OF THE EASTERN ANTICLINE}

The two grabenlike troughs on the Eastern anticline appear to have been formed by structural elongation southeastward in the upper several thousand feet of Pliocene rocks (Maher and others, 1972). The troughs are bounded at their base by a gliding surface along the top of the Reef Ridge Shale, which being partly siliceous is considerably harder and stronger than the overlying nonsiliceous Tupman Shale Member. The long master fault, or fault zone, that is postulated subparallel to the bedding at the top of the Reef Ridge Shale joins a fault that curves upward near the crest of the Eastern anticline and approaches the land surface about 1 mile west of the crest. This fault pattern was duplicated in experiments with models by Cloos (1968, fig. 16) in which one side of the model was pulled away from the other.

The postulation of a master fault subparallel to the bedding planes is supported by a comparison of the total structural elongation due to faulting at two stratigraphic horizons-the top of the Carman Sandstone Member and the top of the underlying Tupman Shale Member. This comparison can be made most readily on a structural section drawn with equal horizontal and vertical scales as shown by figure 30 . The measurements of horizontal separation in the plane of section $\mathrm{CDE}^{\prime}$ are only relative because the section is not perpendicular to the fault traces. However, these relative measurements can be used to compare the elongation of the two horizons. If the structural troughs were rigidly bound, the total horizontal separation within the grabens would be the same at the top of both the Carman Sandstone and Tupman Shale Members. However, the Carman horizon appears to be elongated by 2,190 feet across troughs $\mathrm{A}$ and $\mathrm{B}$, and the deeper Tupman horizon appears to be elongated by only 1,390 feet, a difference of 800 feet in the present distance of 35,800 feet across both troughs. The original distance before the troughs formed was between 33,610 feet and 35,800 feet. A rough calculation shows that the Carman horizon has been elongated about 6 percent and the Tupman horizon

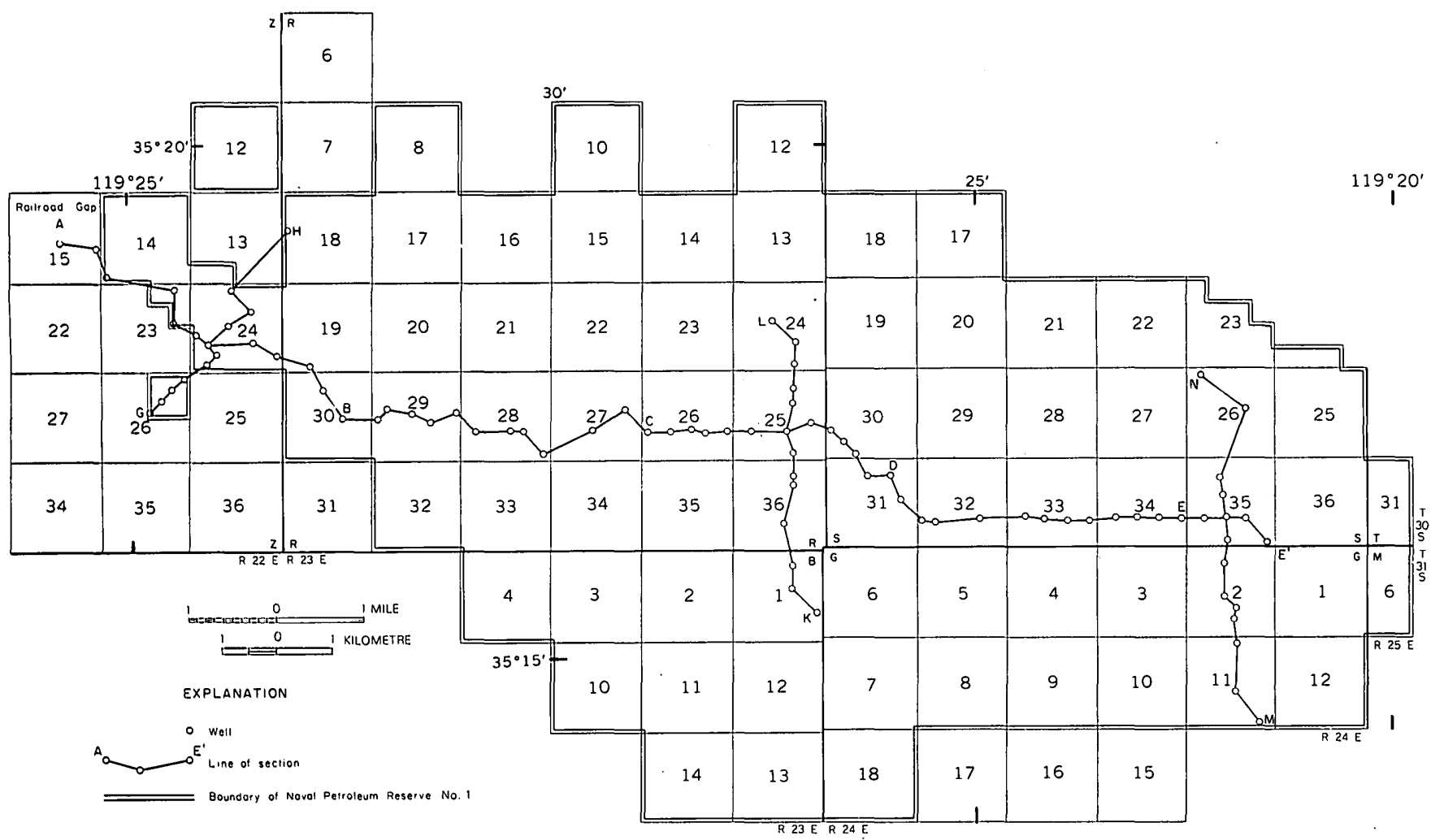

FIGURE 29.-Lines of structure sections across the Elk Hills oil field. 


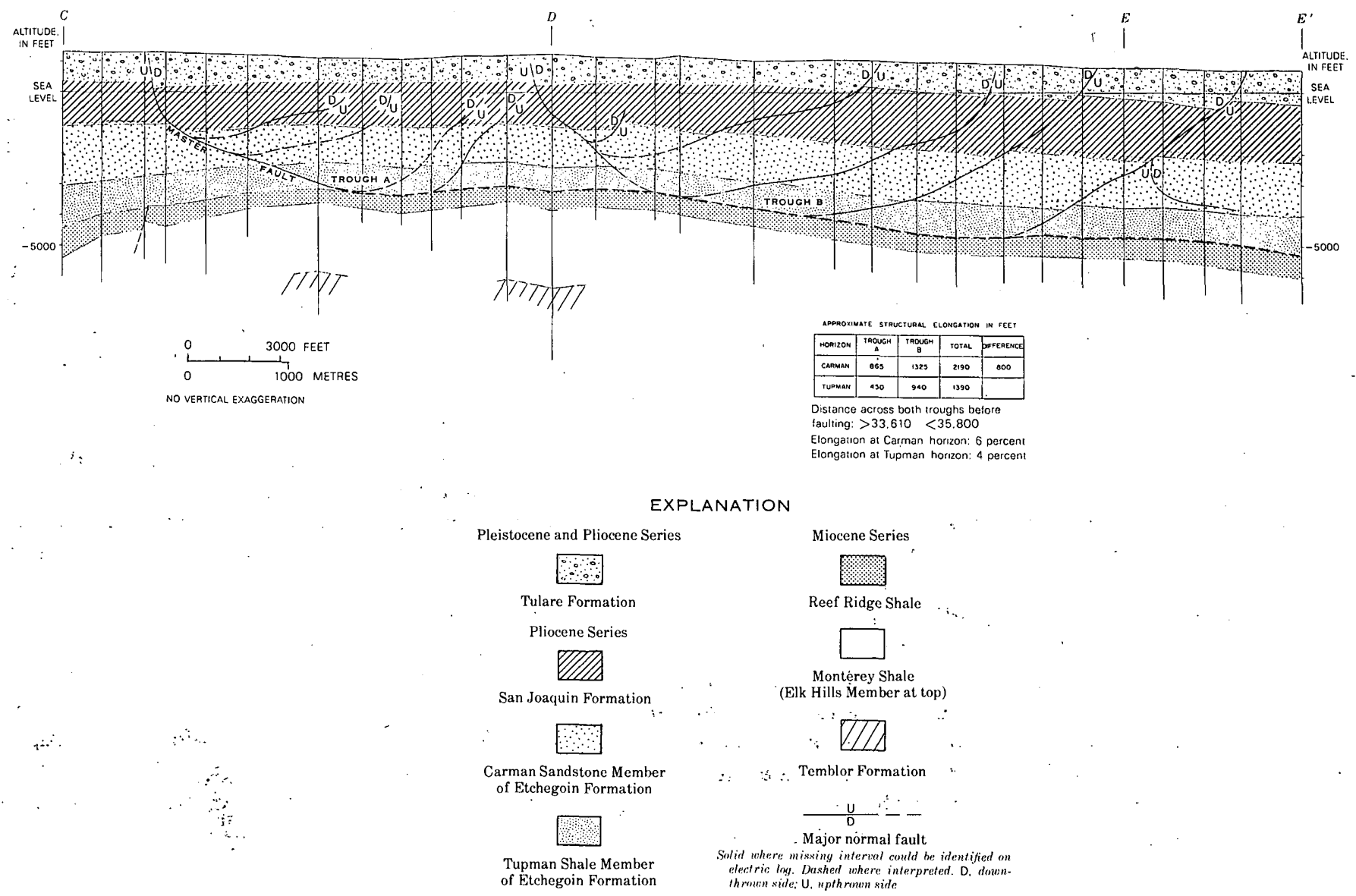

FIGURE 30.-Fault system of the Eastern anticline.

about 4 percent. The difference of 800 feet or 2 percent in the elongations of these horizons indicates that the structural troughs have sides that have expanded to allow more stretch in their upper strata than in their lower strata. The only mechanism for this expansion is displacement along a bedding surface. The restriction of all but one fault to Pliocene and younger rocks, the projection of the curving fault surfaces, and the lithologic contrast between the hard partly siliceous rocks of the Reef Ridge Shale and the overlying softer rocks point to the top of the Reef Ridge Shale as the probable gliding surface for the master fault.

Structure sections across the North Coles Levee oil field immediately east of Elk Hills (Hardoin, 1962, pls. 4, 5) suggest that this fault system may be present there. The San Joaquin and Tulare Formations are not shown on the sections, but the Etchegoin Formation is cut by several normal faults, whose surfaces dip and flatten southeastward. If these fault surfaces were projected, they would approach the horizontal near the top of the Reef Ridge Shale.

The origin of the fault system on the eastern anticline seems most easily explained by the slipping-plane hypothesis of Quarles (1953, p. 498-500), but the forces that caused the movement cannot be identified with certainty without more regional geological information. Gravity sliding southeastward down the steep north flank of the Tejon basin is one possibility. However, the lack of similar faulting in the post-Miocene rocks of the South Coles Levee oil field, as shown by Dosch $(1962$, pls. 4, 5, 6), casts doubt on this premise because the South Coles Levee oil field is located along the steepest part of the north flank of the Tejon basin. Another possibility seems to be tensional forces related to movement of the San Andreas fault in relation to the Bakersfield arch.

\section{LATE TERTIARY STRUCTURAL HISTORY}

The history of folding and faulting at Elk Hills before middle Miocene time is incompletely known because only a few wells have penetrated rocks older than the Monterey Shale. Dipmeter surveys in some deep wells recorded steep dips in the older rocks, which may indicate complex structural conditions at depth. The development of the Elk Hills structure since Reef Ridge 


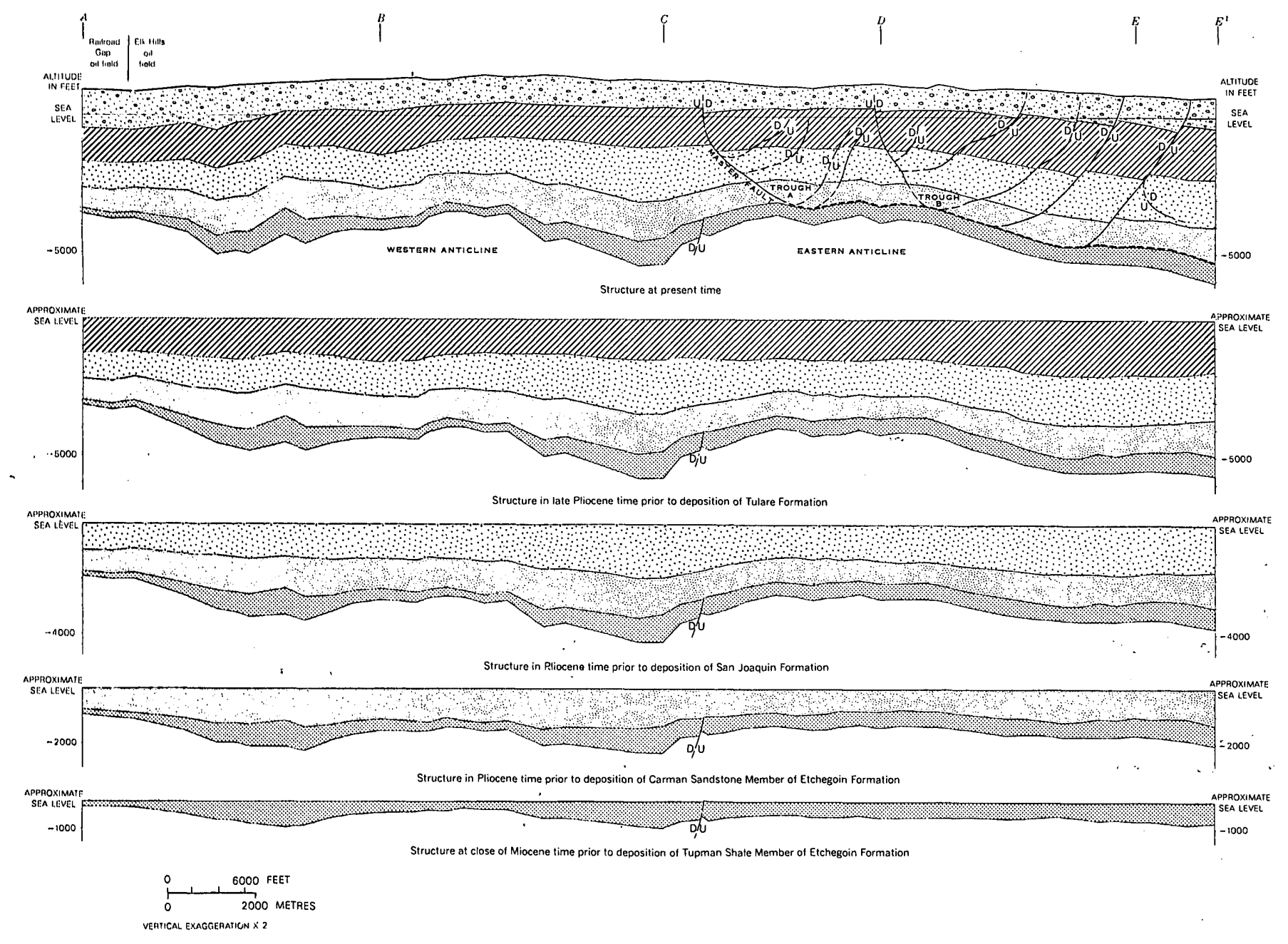

Figure 31.-Structural development along section $\mathrm{AE}^{\prime}$ from Railroad Gap to eastern Elk Hills. Location of section shown in figure 29.

time can be reconstructed, roughly and in part, by assuming that the top of each geologic unit was near sea level at the close of deposition of that unit. This, of course, does not take into account irregularities on the sea bottom or land surface; however, these were likely to have been slight for an area as small as the reserve. Figure 31 and plate 8 reconstruct the development of the Elk Hills structure, using the tops of successively younger rock units as the datum.

The line of section in fig. 31 extends from Railroad Gap eastward to the east end of the nose of the Eastern anticline. It does not cross the highest and lowest points of each anticline, and so maximum structural closures cannot be measured from the section.

Cumulative thickness maps shown on plate 6 compare the cumulative thickness of sediments deposited on the Elk Hills Shale Member for different periods of time. The cumulative thickness maps have an inverse relation to the structure; that is, the sedimentary rocks are generally thickest on the flanks and thinnest on the crests of the anticlines.
The structural diagrams and maps (fig. 31; pl. 6) show that the Western and Eastern anticlines have persisted as separate folds from at least Miocene time to the present. The low point of the syncline separating the two folds along section $\mathrm{AE}^{\prime}$ is near point $\mathrm{C}$ (fig. 31).

At the close of Reef Ridge time (fig. 31; pl. 6) the Western anticline appears to have been slightly higher structurally than the Eastern anticline. The regional tilt was about $4^{\circ}-5^{\circ}$ eastward relative to the base of the Reef Ridge Shale. Movement on a normal fault on the west flank of the Eastern anticline may have occurred just prior to deposition of the Tupman Shale Member of the Etchegoin Formation (fig. 31) which overlies the Reef Ridge, and the resulting scarp may have been high enough above wave base to have undergone some erosion. On the other hand, the fault may have occurred in Tupman time and the fault may be present but obscured in the soft shale of the Tupman. During Reef Ridge time, the seas deposited 200-1,150 feet of clay and silt containing some free silica and carbonate cement in the Elk Hills area. 
During deposition of the Tupman Shale Member (fig. 31 ; pl. 6) the Eastern anticline grew more than the Western one, and at the close of deposition the Eastern one stood slightly higher structurally. Concurrently, shallowing seas deposited as much as 2,000 feet of clay and silt across the area.

During deposition of the Carman Sandstone Member (fig. 31; pl. 6) appreciable uplift took place in the Temblor Range, which produced a regional tilt of about $9^{\circ}$ eastward at Elk Hills. As a result the apparent height of the Eastern anticline, as measured on the top of the Reef Ridge Shale, increased markedly compared with that of the Western anticline. Shallow seas swept large volumes of sand and silt across the area, and more than 1,900 feet of fine to medium siliceous clastic material was deposited along the line of section.

During the deposition of the San Joaquin Formation (fig. 31 ; pl.6) both anticlines rose a few hundred feet as measured on the top of the Elk Hills Shale Member. Regional tilting to the east continued at a slower rate. Shallow seas deposited as much as 2,100 feet of clay, silt, and fine sand across the area.

During late Pliocene, Pleistocene, and Holocene time (fig. $31 ; \mathrm{pl} .6$ ) both anticlines continued to rise slowly, and concurrently, 600-2,200 feet of sand and gravel was deposited in the area. The regional tilting was reversed, and the Western anticline was slightly reduced relative to the Eastern anticline. Surficial tensional stresses caused extensive normal faults that cut obliquely across the axis of the Eastern anticline and resulted in grabenlike troughs in the post-Miocene rocks.

\section{STRATIGRAPHY}

\section{STRATIGRAPHIC SECTIONS}

The stratigraphic framework of Elk Hills is illustrated in this report by ten stratigraphic sections (pls. 7-16) along the lines shown in figure 32. Section AF (pl. 7) is alined with the top of the Reef Ridge Shale (Miocene) as datum. The nine wells on this section are spaced very irregularly at intervals ranging from $1 / 2$ to 7 miles. The remaining nine sections (pls. 8-16) are alined on the Scalez horizon in the lower part of the San Joaquin Formation. Most of the 96 wells on these sections are spaced less than one-half mile apart. Correlations between wells were made mainly by comparison of electric logs at a scale of 1 inch equals 100 feet, taking into account. available lithologic and paleontologic information. Electric logs for numerous intermediate wells along or adjacent to the line of cross section have been used to trace units and horizons not easily correlated between the more widely spaced pairs of wells shown on the cross section.

\section{NOMENCLATURE}

The stratigraphic names for subsurface units at Elk Hills, as shown on the cross sections, represent a working mixture of stratigraphic names used in U.S. Geological Survey reports for outcrops in and around the San Joaquin Valley and oil-field terminology in general use in and near Elk Hills. The formal usage of the U.S. Geological Survey is shown in the outer four columns (pls. 7-16). Some names used for the Oligocene rocks and lower units of the Temblor Formation were taken from outcrops mapped by Dibblee (1973) in the adjacent Temblor Range and were used in Elk Hills for the first time by Adkison (1973). The oil-field terminology is shown in the inside column of plates 7-16. The terms in this column include informal terms used by the Elk Hills Engineering Committee (1957a, b), which were set up for engineering purposes alone rather than as formal stratigraphic units.

\section{OIL-FIELD TERMINOLOGY}

The Elk Hills Engineering Committee defined two oil-productive zones (fig. 33 ; pl. 17) in accordance with the unit plan contract and divided these zones in two reports $(1957 \mathrm{a}, \mathrm{b})$ estimating the recoverable reserves. Some of these divisions have been modified in this report so that they will serve locally as consistent stratigraphic divisions without lessening their value for engineering purposes.

The older and deeper of the two zones is called the Stevens Zone, or more properly the Stevens Oil Zone, and is defined as "all oil and gas bearing formations of Upper Miocene Age within the stratigraphic interval between the top of the Reef Ridge Shale and the top of Valvulineria californica or associated faunas of Middle Miocene Age" (Elk Hills Engineering Committee, 1957b, p. 4). This interval includes the Reef Ridge Shale and all the Monterey Shale except the Gould and Devilwater Shale Members. Within the Stevens Oil Zone are several thick sandstone lenses, the Stevens sands, that contain most of the 700 million barrels of recoverable oil estimated to be in the Stevens Oil Zone. In addition, there are some fractured-shale reservoirs estimated to contain about one-fourth of the reserves in the Stevens Oil Zone.

The Stevens Oil Zone has been divided by the Elk Hills Engineering Committee (1957b, fig. 1) into, in ascending order, the $\mathrm{PG}$ interval, DD interval, $\mathrm{D}$ interval, $\mathrm{C}$ interval, $\mathrm{B}$ interval, $\mathrm{A}$ interval, $\mathrm{N}$ interval, and Reef Ridge Shale (fig. 33). The PG interval is named for the fossil Pulvinulinella gyroidinaformis, which is indicative of the McDonald Shale Member. However, the PG interval also includes the lowermost siliceous shale beds of the Elk Hills Shale Member (the Antelope Shale 


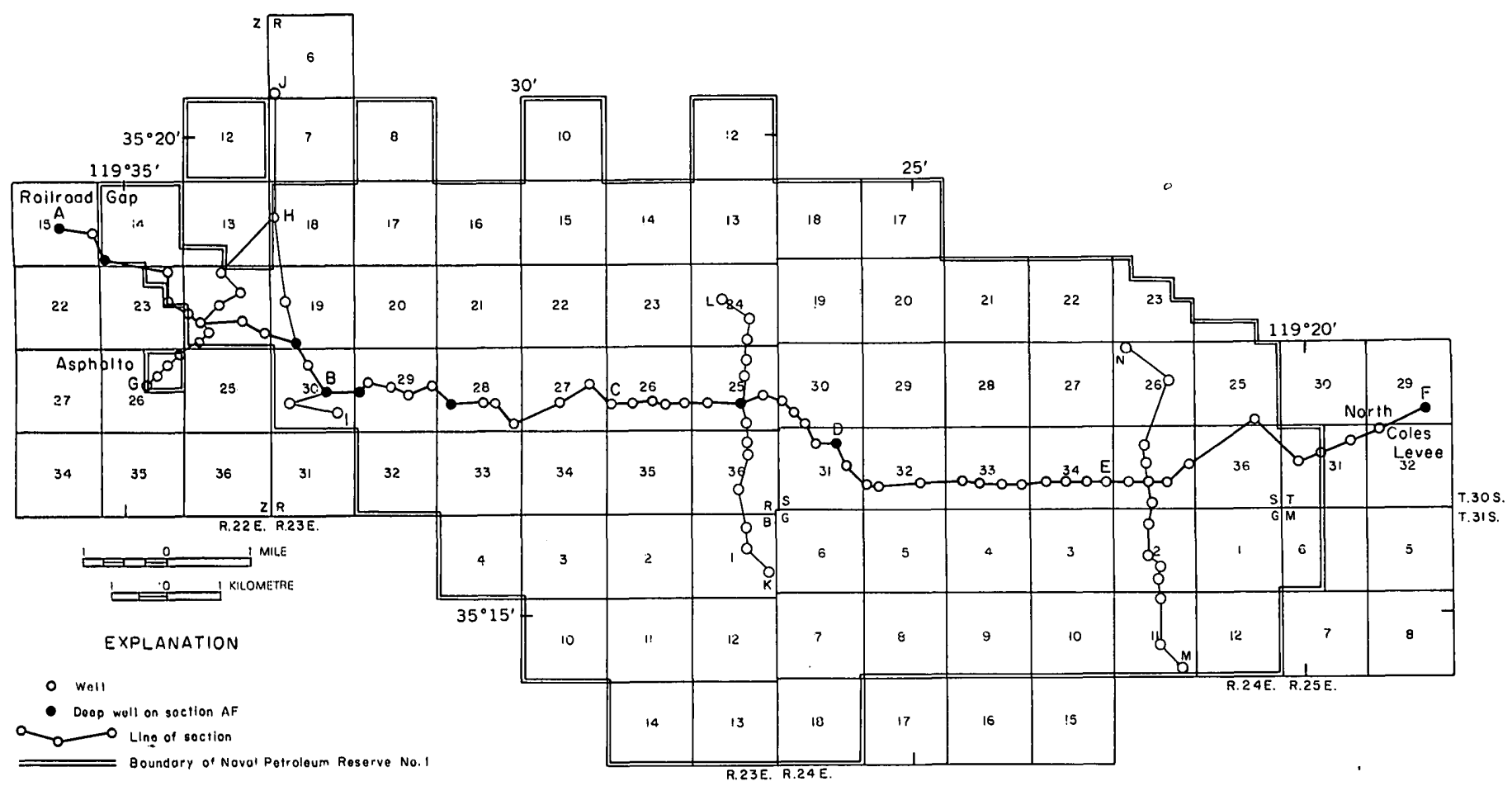

FIGURE 32.-Lines of stratigraphic sections across the Elk Hills oil field.

or Antelope Shale Member of some authors), which do not contain $P$. gyroidinaformis. In this report, the PG interval is dropped and the lowermost siliceous shale beds of the Elk Hills (Antelope) Shale Member are referred to as the $\mathrm{E}$ zone, which lies directly on the McDonald Shale Member. This, in effect, completely divides the Elk Hills Shale Member into seven stratigraphic zones- N, A, B, C, D, DD, and E. The Stevens Oil Zone thus consists, from bottom to top, of the McDonald and Elk Hills Shale Members of the Monterey Shale and the Reef Ridge Shale.

The younger and shallower of the two oil zones, the Shallow Oil Zone (pl. 17), is defined in the unit plan contract as "all oil and gas bearing formations of Pliocene age above the Reef Ridge Shale" (Elk Hills Engineering Committee, 1957a, p. 4). By definition in the unit contract, the Shallow Oil Zone does not include any of the "dry gas bearing formations above the top of the Lower Scales (sic) marker bed" (Elk Hills Engineering Committee, 1957a, p. 4.). The Shallow Oil Zone, with estimated ultimate recoverable reserves of almost 600 million barrels of oil, includes about 16 oil sands, most of which are thin and lenticular enough to cause difficulties in tracing individual sand bodies from well to well. Most of these oil sands are in the upper part of the Etchegoin Formation; a few are in the lower part of the overlying San Joaquin Formation.

The Shallow Oil Zone has been divided, in ascending order, by the Elk Hills Engineering Committee (1957a, fig. 1) into an unnamed interval from the base of the Etchegoin to the base of the Calitroleum group, the Calitroleum group, the Gusher group, the Wilhelm group, an unnamed interval from the top of the Wilhelm group to the base of the Second Subscalez sand, and the Scalez group (pl. 17). Sands within these groups were numbered in descending order (First Gusher, Second Gusher, etc.) by the committee. These designations of individual sands are not indicated in plates $8-16$ because the lenticularity of the sands suggests that the sequences are not consistent throughout the field.

The Shallow Oil Zone intervals called "groups" by the committee are referred to as zones in this report. In addition, the new name Mulinia sand zone has been added for the unnamed interval that includes the Submulinia and Mulinia sands between the Wilhelm sand zone and the Scalez sand zone. The Dry Gas Zone includes all the sands bearing dry gas above the top of the Lower Scalez marker bed. The term is used in this report to include the stratigraphic interval between the Scalez sand zone and the Tulare Formation-the Mya sand zone.

\section{FOSSIL HORIZONS}

Megafossils and microfossils are commonly used in the San Joaquin Valley for age determinations and stratigraphic correlation between wells. In some places, fossil assemblages are used to define zones, or the stratigraphically highest occurrence of a fossil is used 


$$
\begin{aligned}
& \text { RESERVOIR TERMINOLOGY } \\
& \text { OF ELK HILLS }
\end{aligned}
$$

ENGINEERING COMMITTEE (1957b)

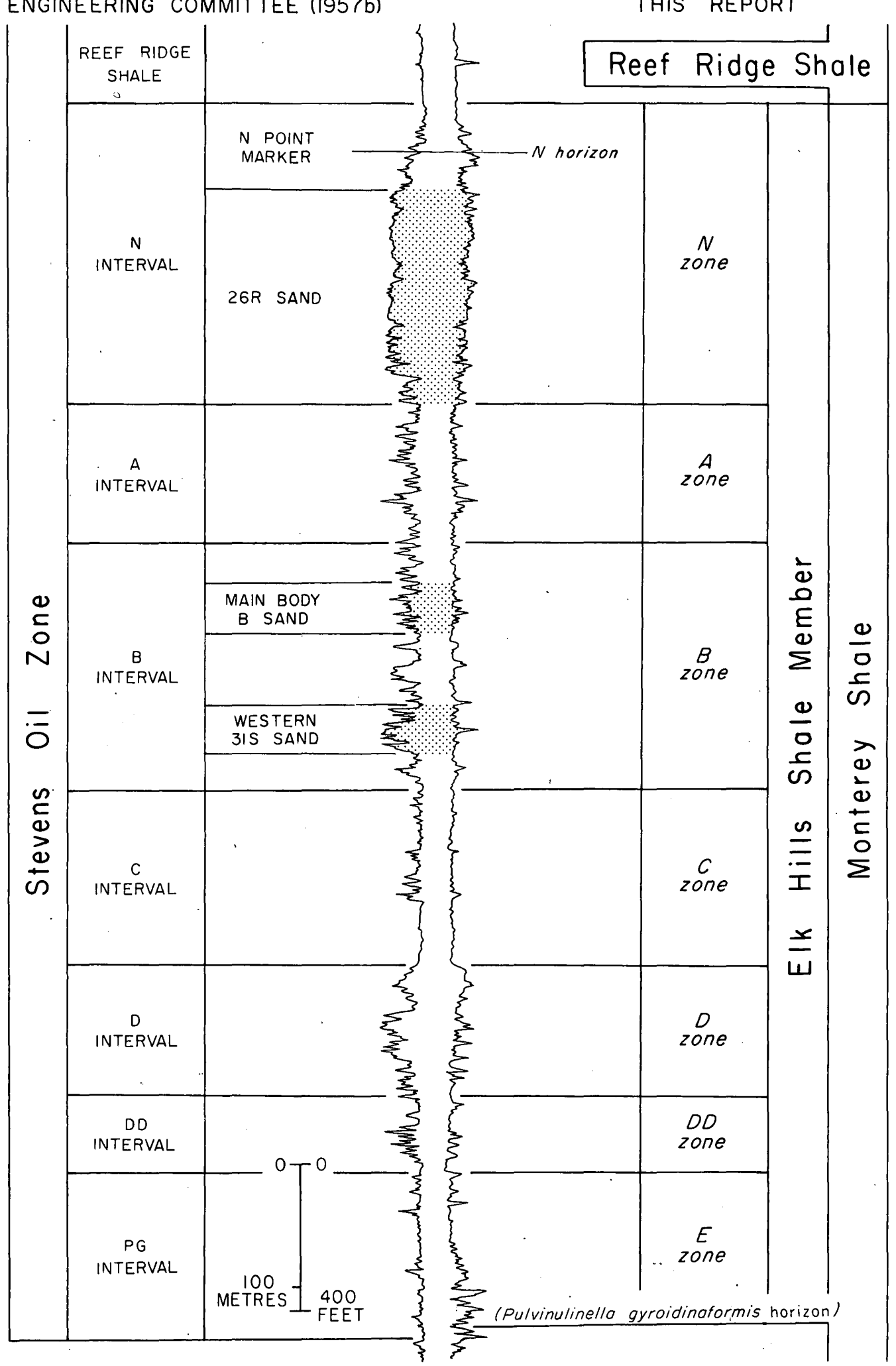

STRATIGRAPHIC TERMINOLOGY

$$
\text { OF }
$$

THIS REPORT 
as a marker for correlation. In others, a single fossil, such as Scalez petrolia (Hanna and Gaylord, 1924, p. 147-149), is present at different levels that are identified sequentially. Many fossil zones and markers were set up years ago from cable-tool samples and have since been translated approximately, and in places incorrectly, into electric-log characteristics. Three of the most commonly used horizons named for fossils are the Scalez (lower), the Mulinia, and the Valvulineria californica. The last named still is identified by fossil occurrences for the most part, but the other two horizons are mostly identified by electric-log characteristics.

\section{ELECTRIC-LOG, HORIZONS}

Several electric-log markers are shown by short dashes on the stratigraphic sections (pls. 7-16). The $Q$ horizon in the upper part of the Elk Hills Shale Member is persistent in the western third of Elk Hills but loses its identity eastward. The $\mathrm{N}$ horizon near the top of the Elk Hills Shale Member, which has been used extensively in economic studies because it provides a datum near the top of the oil-bearing Stevens Zone, can be readily identified only in the central and eastern parts of the field. The F horizon in the middle of the Reef Ridge Shale is an excellent marker in the west half of Elk Hills oil field. The $\mathrm{O}$ horizon in the middle of the Tupman Shale Member of the Etchegoin Formation extends from Railroad Gap entirely across the field to North Coles Levee. These horizons are useful in supporting correlations of formations, members, and zones and in determining modes of thickening and thinning within the larger stratigraphic units.

No consistent stratigraphic units or electric-log horizons are apparent in the upper half of the San Joaquin. Formation. Probably the depositional environment changed too rapidly from shallow marine to lagoonal to deposit continuous marker beds in the upper San Joaquin.

\section{RELATIVE SELF POTENTIAL}

The usual procedures for preparing lithofacies or sand-thickness maps cannot be used effectively at Elk Hills, except for local reservoir studies, because of the lack of samples and lithologic detail for all but a very few wells, the lenticularity of the sand bodies, and the near impossibility of distinguishing the alternating thin beds of sandy shale, siltstone, and fine-grained sandstone from each other by means of electric logs. To obtain some idea of the environment of deposition, source areas, and direction of sediment transport for the monotonous succession of Pliocene fine-grained clastic layers, an indirect averaging method for relatively thick intervals was devised. This method consists of measuring with a planimeter the area on like-scaled electric logs between a shale-base line and the selfpotential curve, dividing the resulting area by the thickness of the stratigraphic unit in feet, and multiplying by 10,000 to provide whole numbers termed the relative self potential (RSP). The shale-base line is a straight line drawn through points of minimum deflection of the self-potential curve that are thought to represent the normal response to clay-shale beds of low porosity and permeability. Although the placement of the shale-base line is subjective, it probably is fairly consistent with electric logs of like scale, made under similar conditions, and for closely spaced wells as at Elk Hills. The larger relative self-potential values indicate relatively higher porosity and larger grain size on the average. These values are useful for rough comparative purposes even though no rock parameters can be quantitatively measured.

\section{REFERENCE SECTIONS AT ELK HILLS}

Samples and cores from 31 wells were examined under a binocular microscope and described as a part of this investigation. Relatively complete sets of samples and cores were available for only three of these wells, all located near the west end of the field. These three wells were selected for subsurface reference sections in which the detailed lithologic descriptions and fossils could be related to electric-log characteristics.

A reference section for upper Oligocene and Miocene rocks was established by Adkison (1973) in parts of wells 526-30R and 555-30R, both located in sec. 30 , T. 30 S., R. 23 E. Well 555-30R was used for the upper Oligocene and lower Miocene Temblor Formation because it made the greatest stratigraphic penetration of these rocks and many cores were taken. Well 526-30R was used for the middle and upper Miocene Monterey and Reef Ridge Shales because the rotary samples collected at 10 -foot intervals are much better than those taken at larger intervals in well 555-30R. The lithologic logs and electric logs for both wells appear on stratigraphic section IJ (pl. 14). The electric log only for well $555-30 R$ is shown on stratigraphic sections AF, $\mathrm{AB}$, and $\mathrm{BC}$ (pls. 7-9).

A reference section for Pliocene rocks was established by Berryman (1973) in well 324-19R, located in sec. 19, T. $30 \mathrm{~S}$,, R. $23 \mathrm{E}$.; less than $1 \frac{1 / 2}{2}$ miles north of the reference sections for Oligocene and Miocene rocks. Well 324-19R was cored almost continuously for 4,000 feet through the San Joaquin and Etchegoin Formations. The lithologic log and electric log for well 324 . 19R appear on stratigraphic section $\mathrm{IJ}$ (pl. 14).

The reports setting up the three reference sections in 
the western part of the Elk Hills oil field presented detailed descriptions of the lithologic characteristics and fossils of the stratigraphic units. In addition they discussed at length the history of nomenclature for units in the Temblor and younger formations. In the following discussion of the stratigraphy of the entire oil field, these lithologic descriptions are generalized and used with electric-log interpretations. The nomenclature and significant changes in its usage at Elk Hills are reviewed briefly. Reference may be made to Adkison (1973) and Berryman (1973) for more details on the lithology and history of the Temblor and younger stratigraphic units and to Dibblee (1973) for discussion of regional correlations along the Tertiary outcrops in the Temblor Range to the west.

\section{ROCKS OF MESOZOIC AGE}

Basement rocks have not been penetrated by wells in the Elk Hills oil field, but green metamorphic rocks of Jurassic (?) age were reported below the Point of Rocks Sandstone Member of the Kreyenhagen Formation (Eocene) in well CLA 67-29T in the North Coles Levee oil field (section AF, pl. 7). The first green grains in the drill cuttings from this well were reported in a sample from 17,860 to 17,880 feet. The green rock fragments may represent either weathered basement rock in place or reworked fragments incorporated in an overlying sandstone. Because of the considerable lag in rotary samples from this depth, it probably came from a depth of about 17.840 feet, where the electric log indicates a decided change in lithology. Unweathered green metamorphic rock was cored from 17,881 to 18,893 feet. The top of the basement is not deeper than 17,881 feet and may be as shallow as 17,840 feet.

\section{ROCKS OF EOCENE AGE}

\section{KREYENHAGEN FORMATION}

In this report, the Kreyenhagen Shale is treated as the Kreyenhagen Formation, and the Point of Rocks Sandstone is reduced to a member of that formation. This eliminates the confusion caused by using the Point of Rocks Sandstone as a formation within a formation, the Kreyenhagen Shale. The shale above the Point of Rocks Sandstone Member, previously referred to as the upper Kreyenhagen Shale, or the Kreyenhagen Shale in some reports, is correlated with the type Welcome Shale Member, the upper member of the Kreyenhagen Formation in the Temblor Range (Dibblee, 1973, p. 12, 13). Eocene rocks correlative with the Kreyenhagen along the west side of the San Joaquin Valley are represented by two interfingering facies-a sandy facies at the south end known as the Tejon Formation and a clay shale facies near Coalinga to the north termed the Kreyenhagen Shale. Both have formation status. In the area between the two extremes, including Elk Hills and vicinity, the Eocene rocks consist of all or part of a lower shale, middle sandstone, and upper shale sequence. Geologists in the petroleum industry have referred to these units as the lower Kreyenhagen Shale, the Point of Rocks Sandstone, and the upper Kreyenhagen Shale (Church and others, 1959). Van Couvering and Allen (1943, p. 497) in their report on the Devils Den area (fig. 34) classified the upper Eocene rocks in ascending order into the Gredal Formation, the Point of Rocks Sandstone, and the Welcome Formation. Foss and Blaisdell (1968, p. 41-42) applied the name Kreyenhagen Formation to the entire sequence along the west side of the southern San Joaquin Valley and divided it in upward order into the Canoas Siltstone Member, Point of Rocks Sandstone Member, and the Welcome Member. Recently Dibblee $(1973$, p. 12, 13) used the names Gredal Shale Member and Welcome Shale Member, modifications of Van Couvering and Allen's terms (1943, p. 496-500). However, Dibblee retained

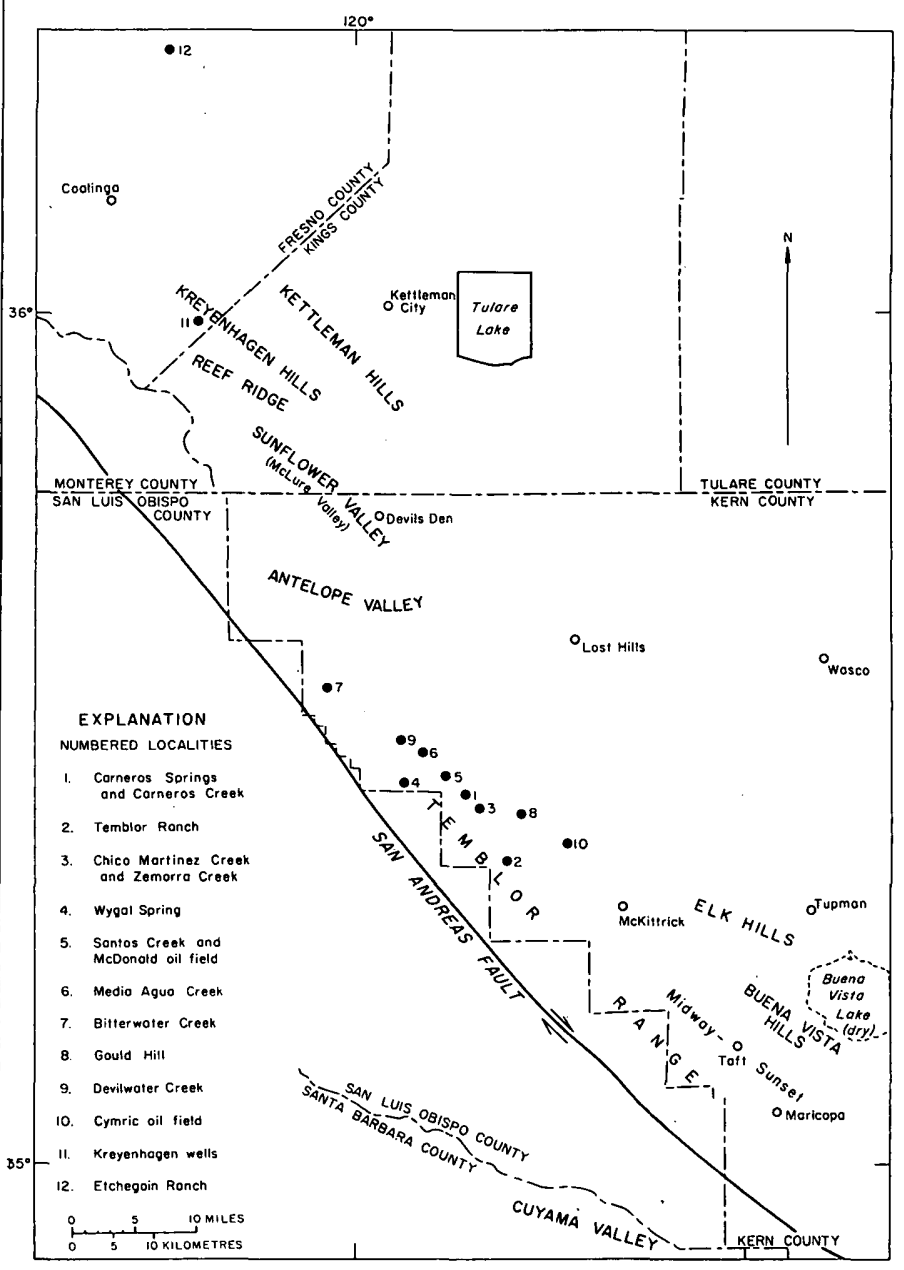

FIGURE LOCATION OF ELK HILLS IN RELATION TO MOST OUTCROP LOCALITIES DISCUSSED IN THIS REPORT

FiguRE 34.-Location of Elk Hills in relation to most outcrop localities discussed in this report. 
the Point of Rocks Sandstone as a formation. In view of the fact that the Point of Rocks is a tongue of sandstone between two shale members in the Kreyenhagen (Church and others, 1959), it seems necessary to regard it as a member and to use the term Kreyenhagen Formation, rather than Kreyenhagen Shale, to indicate the different lithologies of these members.

The Kreyenhagen Formation was originally named "Kreyenhagen Shales" by Anderson (1905, p. 163) for its exposures about 900 feet thick near Kreyenhagen wells (fig. 34), on Canoas Creek about 12 miles south of Coalinga, Fresno County. It overlies the basal Tertiary sandstone-the Avenal Sandstone-and underlies the Wagonwheel Formation of Oligocene age. In the outcrops nearest to Elk Hills, it consists mainly of darkbrown to medium-gray fissile shale and fine- to coarsegrained arkosic sandstone but includes some lavenderbrown siliceous siltstone also. Fish remains, sponge spicules, and radiolarians are common: The Kreyenhagen has not been penetrated by wells drilled in the Elk Hills oil field. Well 67-29T in the North Coles Levee oil field drilled through 2,324 feet of Kreyenhagen composed of the Point of Rocks (?) Sandstone Member and the Welcome Shale Member into green metamorphic rock of Jurassic (?) age. The Gredal Shale Member is not present. Well 555-15Z in the Railroad Gap oil field penetrated 2,863 feet of Kreyenhagen but stopped in the Point of Rocks Sandstone Member, which is made up of two thick sandstones in that area.

\section{GREDAL SHALE MEMBER}

The Gredal Shale Member was named the Gredal Formation by Van Couvering and Allen (1943, p. 497) in outcrops near the Devils Den oil field, about 45 miles northwest of the Elk Hills oil field. They described the unit as "variegated, green-red claystone containing occasional sandstone beds and considerable glauconite" and assigned a thickness of 1,000 feet to it but did not specify a type locality. Mallory (1959, p. 45) reduced the unit to member status within the Lodo Formation. Church, Krammes, and others (1959) used the term Lower Kreyenhagen Shale for the same shale unit in wells at Lost Hills (fig. 34). Foss and Blaisdell (1968, p. 42) referred equivalent beds to the Canoas Siltstone Member of the Kreyenhagen Formation in their study of the west side of the southern San Joaquin Valley.

Dibblee (1973, p. 12) adopted the Gredal into nomenclature of the U.S. Geological Survey as a shale member of the Kreyenhagen Shale and designated its type section in NE $1 / 4$ sec. 10, T. 26 S., R. 18 E., 4 miles south of Devils Den (fig. 34). He described it as about 750 feet of gray clayey shale with local occurrences of green and red clay and noted that the unit is only 100 feet thick at Media Agua Creek, 25 miles northwest of Elk Hills (fig.
34). Wells have not been drilled deep enough at Elk Hills and adjacent fields to the west to reach the Gredal Shale Member. It is absent from well CLA No. 67-29T in the North Coles Levee oil field, where the Point of Rocks (?) Sandstone Member rests directly on Mesozoic (Jurassic?) rocks.

\section{POINT OF ROCKS SANDSTONE MEMBER}

Reed and Hollister (1936, p. 1566) named the Point of Rocks Sandstone on a columnar section of upper Eocene strata in the Devils Den area (fig. 34) but did not locate and describe a type section for the unit. According to Foss and Blaisdell (1968, p. 42), the name was derived from a locality, Point of Rocks, in sec. 2, T. 26 S., R. 18 E., northwest of the Welcome Valley oil field in northern Kern County. Van Couvering and Allen (1943, p. 497) showed a thickness of 3,005 feet for the Point of Rocks Sandstone in the Devils Den district and described the unit as "tawny, massive, cavernous, crossbedded, medium to coarse, quartzose sandstone; contains large chocolate-brown concretions in lower part." They noted two silty claystone beds in the lower one-third of the sandstone. The large red-brown "cannonball" concretions, in some places as much as 4 feet in diameter, give the sandstone outcrop a distinctive appearance. In a paleontologic correlation study of Eocene rocks exposed along Zemorra Creek about 16 miles northwest of Elk Hills, Curran (1943, p. 1366, 1367) described in detail the lithology and paleontology of the "Tejon" sandstone, later referred to as the Point of Rocks Sandstone (Elliott and others, 1968 , p. 108, 112). He divided the 2,300 feet of the partially exposed unit into seven members-four massive sandstone beds separated by three shale beds-27-160 feet thick. Curran (1943, p. 1380, 1383) was unable to correlate the "Tejon" of Zemorra Creek with the type Tejon Formation on the basis of foraminiferal assemblages but suggested that the "Tejon" sandstone on Zemorra Creek was deposited simultaneously with the Point of Rocks Sandstone and the Kreyenhagen Shale as known in outcrops farther north.

Heikkila and MacLeod (1951, p. 71) mapped the Point of Rocks Sandstone as a formation on Bitterwater Creek (fig. 34). A maximum thickness of 600 feet is exposed there. The sandstone rests unconformably on rocks of Cretaceous age and is overlapped by the Agua Sandstone and upper Santos Shale of the Temblor Formation. Mallory (1959, p. 20) referred to the Point of Rocks Sandstone as a member of the Tejon Formation as did the San Joaquin Geological Society Guidebook (McMichael and others, 1959, p. 13).

A correlation section along the west side of the San Joaquin Valley from Coalinga southward to MidwaySunset (Church and others, 1959) showed the "Point of Rocks sand" to be many thousands of feet thick in wells 
in the Belgian anticline and Cymric areas but less than 1,000 feet thick in the Lost Hills area. North of Lost Hills the sand wedges out into a shale sequence of the Kreyenhagen Formation.

The Point of Rocks Sandstone was considered a marine littoral facies of the Kreyenhagen Shale by Hoots, Bear, and Kleinpell (1954, p. 119). Repenning (1960, p. 26) noted this facies relationship and that the Point of Rocks Sandstone was the earliest Tertiary deposit south of the Bakersfield arch.

Foss and Blaisdell (1968, p. 42) discussed the Point of Rocks Sandstone along the west side of the southern San Joaquin Valley as a member of the Kreyenhagen Formation and gave a maximum thickness in excess of 5,000 feet. They pointed out the interfingering relationship of the sandstone with the overlying and underlying shale members of the Kreyenhagen. Foss (1972, p. 43) expanded on the facies relations within the Kreyenhagen and stated that "The Point of Rocks Sandstone which is thousands of feet thick is in a narrow trough parallel to the present front of the Temblors and extending down to the southern end of the valley where it is represented by the Metralla Sandstone. This sand was probably deposited in the bottom of a deep basin with over-steepened flank." The Point of Rocks Sandstone was compared with the Butano Sandstone of the Santa Cruz Mountains by Clarke and Nilsen (1972, p. 137138). They concluded that the two were originally a single large deep-sea fan deposit and have been separated by displacement along the San Andreas fault. Dibblee (1973, p. 13) adopted the name from the original description, by Van Couvering and Allen, of the Point of Rocks area 3 miles south of Devils Den.

Two wells at opposite ends of the Elk Hills oil field have penetrated the Point of Rocks Sandstone Member, but none within the field itself. Well 555-15Z in the Railroad Gap oil field drilled 1,938 feet of beds assigned to the Point of Rocks without reaching older rocks. The sequence is divided by about 200 feet of shale into two thick sandstone units known in oil-field terminology as the First and Second Point of Rocks sands. Well 67-29T in the North Coles Levee oil field penetrated 379 feet of sandstone questionably assigned to the Point of Rocks Sandstone Member before reaching gold-bearing (Simonson, 1958, p. 104, fig. 5) green metamorphic rock of Jurassic(?) age. The Point of Rocks Sandstone Member at a depth of 17,620 to 17,873 feet in this well produced at an initial rate of 61 barrels of $38^{\circ}$ crude oil and 1,750,000 cubic feet of gas per day (Hardoin, 1962, p. 55-56).

\section{WELCOME SHALE MEMBER}

The Welcome Shale Member was originally described as the Welcome Formation in the Devils Den district (fig. 34) by Van Couvering and Allen (1943, p. 496, 497). They described the unit, 1,020 feet thick, as "lavenderbrown, siliceous, splintery siltstone and claystone; occasional foraminifera." Smith (1956, p. 67) reduced the rank of the unit to a member of the Kreyenhagen Shale for the equivalent beds in wells at Lost Hills. Foss and Blaisdell (1968, p. 42) discussed the previous informal and improper usage of Kreyenhagen Shale Member for this unit within the Kreyenhagen Formation and recommended the substitution of the term Welcome Member. They noted that the maximum thickness along the west side of the southern San Joaquin Valley is about 1,500 feet. Dibblee (1973, p. 12-13) designated this unit the Welcome Shale Member of the Kreyenhagen Shale with its type section in Welcome Valley (SE $1 / 4$ sec. 35 , T. 25 S., R. 18 E., NE1/4NE $1 / 4$ sec. 2 and NW1/4 sec. 1, T. 26 S., R. 18 E.) near the south side of Devils Den.

The Welcome Shale Member of the Kreyenhagen Formation has been drilled through by wells in the Railroad Gap and North Coles Levee oil fields (pl. 7), and a thickness of 85 feet was penetrated by one well (532-25Z) in the Asphalto oil field. Well 555-15Z in Railroad Gap to the west drilled through a sequence of the Welcome, 910 feet thick. Well 67-29T in North Coles Levee to the east penetrated 1,934 feet of the Welcome Shale Member. The thickness of the member appears to more than double across Elk Hills.

\section{ROCKS OF OLIGOCENE AGE \\ WAGONWHEEL FORMATION}

The Wagonwheel Formation was named by Johnson (1909, p. 63). He applied the name to exposures of marine basal sandstone and clayey shale, about 500 feet thick, at Wagonwheel Mountain in the Devils Den area (fig. 34) and assigned an Oligocene(?) age to them. This is the first published record of marine Oligocene beds in the San Joaquin Valley, although almost the same beds had already been mapped as "Oligocene(?) rocks" by Arnold and Johnson (1910, p. 40-41), who described in detail a 1820-foot-thick section of these rocks.

Jenkins (1931, p. 155) concluded that the lower 570 feet of Arnold and Johnson's (1910) published section represents "a distinct formation overlying the true Kreyenhagen shale and underlying the Miocene sandstone." Church (1931, p. 204) did not separate these beds from the Kreyenhagen Shale. Gester and Galloway (1933, fig. 3) recognized a Wagonwheel unit of Oligocene age within their Kreyenhagen Group in a correlation chart for the west side of the San Joaquin Valley. Atwill (1935, p. 1203) correlated his Tumey Formation in Fresno County with outcrops of the Wagonwheel on Wagonwheel Mountain.

Kleinpell (in Hoots and Herold, 1935, p. 126) classed the Wagonwheel Formation as Oligocene(?) and de- 
scribed it as a sequence of argillaceous brown shale interbedded with sandy beds in the lower part, 0-600 feet thick. Van Couvering and Allen (1943, p. 496-497) described the Wagonwheel Formation as 760 feet of fossiliferous sandstone and siltstone in the Devils Den oil field.

The Foraminifera and lithology of the Wagonwheel Formation were described in detail by Smith (1956, p. 67-71). His stratigraphic column showed a 470-foot sequence of Oligocene age (Refugian) lying conformably on the Kreyenhagen Shale but unconformably beneath the Temblor Formation. He divided the formation into three informal members: (1) a lower sandstone, 100 feet thick, (2) a middle argillaceous siltstone, 330 feet thick, and (3) an upper glauconitic siltstone, 40 feet thick.

Church and others (1959) used the terms Oceanic Sand and Tumey Shale for Oligocene rocks equivalent to the Wagonwheel Formation in wells in oil fields near Elk Hills. Foss and Blaisdell (1968, p. 41) also used these names along the west side of the southern San Joaquin Valley but pointed out that the name Wagonwheel had precedence and its type locality is closer to the west-side oil fields. They stated that the Tumey Shale is as much as 1,600 feet thick in the Devils Den area but less than 500 feet thick to the south. Dibblee (1973, p. 13) in his discussion of outcrops in the southern Coast Ranges adopted the older name Wagonwheel Formation into the nomenclature of the U.S. Geological Survey. This usage is extended into the subsurface in this report and applied to the beds previously called Tumey Shale in oil-field terminology at Elk Hills.

The Wagonwheel Formation has not been reached by wells in the Elk Hills oil field. Well 532-25Z in the Asphalto oil field near the western boundary of NPR-1 drilled through 265 feet of the Wagonwheel Formation and 85 feet into the Welcome Shale Member of the Kreyenhagen Formation. Well 555-15Z in the Railroad Gap oil field to the west drilled through 255 feet of beds assigned to the Wagonwheel Formation; well 67-29T in the North Coles Levee oil field to the east penetrated 710 feet of these rocks (pl. 7). These data show that the unit thickens considerably eastward. No equivalent of the so-called Oceanic sand is present in the wells.

\section{ROCKS OF OLIGOCENE AND EARLY MIOCENE AGE} TEMBLOR FORMATION

The Temblor Formation was named by Anderson (1905, p. 169-170), who described a sequence of sandstone and shale about 1,500 feet thick at Carnara Springs and at Temblor Ranch (fig. 34) in western Kern County as the "Temblor Beds," of early Miocene age. Approximately equivalent beds in the western part of Salinas Valley had been named the Vaqueros Sandstone (Hamlin, 1904, p. 14), a name later used by some geologists for the Temblor in the San Joaquin Valley and adjacent areas. The correlation and age relations of the Temblor and Vaqueros became the subject of controversy, and many papers regarding their correlation were published over the years. The evolution of the presently accepted classification by Bandy and Arnal (1969) has been summarized by Adkison (1973, p. 7-10).

The original description of the Temblor by Anderson (1905, p. 169, 170) at Carnara Springs and at Temblor Ranch was very general and did not clearly designate a type section. Recently Dibblee (1973, p. 20) cleared. up the confusion by designating the Temblor's type section as that exposed at Carneros Creek, the type area as the outcrop area from Carneros Creek to Zemorra Creek, and the reference section as that exposed on Zemorra Creek.

The Temblor Formation, according to the stratigraphic correlation chart of Bandy and Arnal (1969, pl. 1) modified from Beck (1950), includes beds of both Oligocene (Zemorrian) and early Miocene (Saucesian) ages. This chart shows the following units within the type Temblor along the west side of the San Joaquin Valley, in ascending order: Salt Creek (Shale), Phacoides (sand), lower Santos Shale, middle Santos Shale, Agua Sand, upper Santos Shale, Carneros Sand, Media Shale, and Button Beds. The boundary between the Oligocene and Miocene is placed at the top of the Agua sand, a lenticular sandstone body in the Santos Shale. Nearly the same classification has been used by the oil industry in wells near or at Elk Hills. (See section "Oil-Field Terminology" and pl. 7.) The principal differences are that the poorly defined Agua sand equivalent, mostly siltstone and shale, is not identifiable in all wells and the Button Beds (Buttonbed Sandstone Member of Dibblee, 1973, p. 23, 24) generally are not present in the subsurface. Outcrop studies in the Temblor Range between Chico Martinez Creek and Bitterwater Creek by Dibblee $(1973$, p. 20,21 ) have resulted in the adoption by the U.S. Geological Survey of the name Cymric Shale Member for the Salt Creek Shale and the Wygal Sandstone Member for the Phacoides sand. These names are extended into the subsurface at Elk Hills in this report.

, In wells in Elk Hills and vicinity, the thickness of the Temblor Formation ranges approximately from 2,900 to 4,100 feet. The whole unit has been penetrated by well 555-15Z in the Railroad Gap field, well 532-25Z in the Asphalto field just outside the west boundary of NPR-1, and well 67-29T in the North Coles Levee field. A thickness of 3,801 feet of steeply dipping Temblor was penetrated in well 555-30R before drilling stopped in the lower part of the formation. Adkison (1973, p. 10) estimated the true thickness of the part of the formation that was penetrated there to be $2,400-2,700$ feet. About 
500 feet of the Temblor was penetrated by well $526-30 \mathrm{R}$ nearby. The stratigraphic succession of alternating shale and sandstone members in the Temblor is best represented by the 2,951-foot sequence in well 555-15Z, Railroad Gap, closest to the outcrops in the Temblor Range.

\section{CYMRIC SHALE MEMBER}

Until 1973 the lowest member of the Temblor Formation was known as the Salt Creek Shale, presumably named after Salt Creek southwest of the Cymric oil field (fig. 34). The name was first published by Williams (1936, p. 12). It was used in subsequent years by Goudkoff (1943, pt. 2, p. 250, fig. 99a), Curran (1943, p. 1368-1369), McMichael and others (1959, p. 13), Foss and Blaisdell (1968, p. 40), and Bandy and Arnal (1969). The unit was renamed the Cymric Shale Member for the Cymric oil field near Salt Creek, and its type section was designated in Zemorra Creek, sec. 9, T. 29 S., R. 20 E. (Dibblee, 1973, p. 20). There the Cymric Shale Member consists of 74 feet of dark-gray clayey to silty shale resting disconformably on the Point of Rocks Sandstone Member of the Kreyenhagen Formation.

The Cymric Shale Member has been penetrated by only three wells in the vicinity of Elk Hills. On the west side it is 315 feet thick in well 555-15Z (Railroad Gap) and may be about 200 feet thick in well 532-25Z (Asphalto). On the east side, the thickness of the Cymric may be over 600 feet in well 67-29T (North Coles Levee). The lower members of the Temblor Formation cannot be separated with confidence at either place.

WYGAL SANDSTONE MEMBER

The Wygal Sandstone Member was formerly known as the Phacoides sand or Phacoides reef (Gester and Galloway, 1933, fig. 13; Kleinpell, 1938, p. 107; Goudkoff, 1943, pt. 2, p. 250; Curran, 1943, p. 1368; Church and others, 1959; McMichael and others, 1959, p. 13; Foss and Blaisdell, 1968, p. 40; Bandy and Arnal, 1969). Dibblee (1973, p. 20) pointed out that these names are invalid because they refer to a fossil rather than a locality. He renamed the sandstone the Wygal Sandstone Member for Wygal Spring and designated its type section at Zemorra Creek, sec. 9, T. 29 S., R. 20 E. (fig. 34).' There the member is about 75 feet thick and is composed of gray sandstone that contains glauconite in its upper part and fossiliferous calcareous beds at its base.

The Wygal Sandstone Member is 456 feet thick in well 555-15Z in Railroad Gap. It appears to be about 50 feet thick in well 532-25Z in Asphalto, although the contacts of the lower members of the Temblor are not well defined in this well. The Wygal Sandstone Member cannot be separated from the overlying Santos Shale Member in well 67-29T in the North Coles Levee oil field. It is not known to have been penetrated by wells within the Elk Hills oil field.

\section{SANTOS SHALE MEMBER}

In 1933, Gester and Galloway (1933, fig. 3) used the name Santos Shale on a correlation chart of the west side of the San Joaquin Valley. Dibblee (1973, p. 22) regarded Santos Creek (fig. 34) in Kern County as the type locality and source of the name.

The Santos Shale Member is made up of light-gray and tan to dark-brown shale and siltstone, in places divided into upper and lower parts by medium- to coarse-grained micaceous and glauconitic sandstone known as the Agua Sandstone Member. Where divided in this fashion, the two shale units have been termed Lower and Upper Santos Shale Members (Heikkila and MacLeod, 1951, p. 8; McMichael and others, 1959, p. 13; Church and others, 1959; Foss and Blaisdell, 1968, p. 39, 40). Bandy and Arnal (1969) included a fourth unit, their Middle Santos Shale. Dibblee (1973, p. 20, table 2) described the Agua Sandstone Member as discontinuous lenses within the Santos Shale Member in the Temblor Range between Chico Martinez Creek and Bitterwater Creek (fig. 34). The classification of the Agua as a member within a member creates an awkward terminology. The Agua, a relatively thin and less persistent sandstone reinterpreted as a sandstone bed within the Santos Shale Member, is here redesignated the Agua Sandstone Bed.

The reference section for the Santos Shale Member is located on Zemorra Creek, where it consists of a lower 180 feet of shale, a middle 35 feet of sandstone (Agua Sandstone Bed of this report), and an upper 60 feet of shale (Dibblee, 1973, p. 22), a total thickness of 275 feet.

In the Railroad Gap oil field, the Santos Shale Member is 1,340 feet thick in well $555-15 \mathrm{Z}$ and 1,812 feet thick in well $518-14 \mathrm{Z}$ only 3,290 feet to the southeast (pl. 7). The Agua equivalent in these wells appears to be 200-250 feet thick. The siltstone and shale sequence composing the Santos Shale Member continues to thicken southeastward to the Asphalto oil field, where a thickness of 3,091 feet was recorded in well 532-25Z. Siltstone and shale equivalent to the Agua may be over 300 feet thick in this well.

Wells in the Elk Hills field that reached the Santos, as shown on section AF (pl. 7), include wells 555-30R, $526-28 R, 556-25 R$, and 562-31S. These wells do not provide data on total thickness because they were not drilled entirely through the member. The indicated thickness of 3,295 feet penetrated by well $555-30 \mathrm{R}$ is misleading because of steep apparent dips $\left(20^{\circ}-80^{\circ}\right)$ of the strata. Adkison (1973, p. 12) estimated the true thickness penetrated to be 2,000-2,300 feet. He described the lithology as mainly dark-gray to brown 
shale, light- to medium-gray siltstone and silty shale, and light gray very fine to coarse-grained sandstone and noted phosphatic grains and glauconite scattered throughout.

In well 562-31S in eastern Elk Hills the siltstone and shale sequence equivalent to the Agua Sandstone Bed is about 200 feet thick but not distinctive enough to be a reliable stratigraphic marker, and it has too little porosity to be a good reservoir for oil and gas. The thickness of the Santos in well 67-29T in the North Coles Levee field is indeterminate within limits of $1,300-2,000$ feet, as the lower units of the Temblor Formation cannot be separated in this well.

\section{CARNEROS SANDSTONE MEMBER}

Carneros Creek, about 15 miles northwest of Elk Hills (fig. 34), contains the type locality for the Carneros Sandstone Member. The name Carneros Sandstone occurs in an unpublished report on the Carneros Creek area by A. R. May and J. D. Gilboe in 1931 and was first published in a correlation table by Goudkoff (1931, table 1) with no discussion. Later Cushman and Barbat (1932, footnote on p. 31) stated that Carneros Sandstone was a name used informally by H. D. Schenck "for the prominent sandstone containing Pecten miguelensis Arnold near the type Temblor section." On Zemorra Creek (fig. 34), 21/2 miles southeast of Carneros Creek, this member is 215 feet thick and consists of medium- to coarse-grained sandstone that includes a thin bed of foraminiferal shale about 80 feet below the top and many zones of hard limy concretions throughout the entire sequence (Woodring and others, 1940, p. 130). According to Dibblee (1973, p. 23), the Carneros in its outcrop along Zemorra Creek is conformable on the underlying Santos Shale Member. In the Bitterwater Creek area about 18 miles farther northwest, Heikkila and MacLeod (1951, p. 9) stated that the Carneros "disappears in an apparent lateral gradation into the upper Santos and Media shales." Foss and Blaisdell (1968, p. 39) also noted this facies change along the west side of the San Joaquin Valley and pointed out that three bodies of sandstone exist within the unit at different places. They described these as (1) a northern sandstone body extending as far south as North Belridge, with a maximum thickness of 2,390 feet in the Bates area, (2) the middle or main Carneros sandstone body extending from the type section to Elk Hills, with a maximum thickness of 2,000 feet, (3) the southern sandstone body in the Temblor Hills west of Midway-Sunset, extending from Crocker Canyon to the Pioneer area, with a maximum thickness of 5,000 feet.

The lithology of the Carneros in wells 526-30R and 555-30R in the western part of Elk Hills was described in detail by Adkison (1973, p. 18-25). In general, the sandstone is light gray to brownish gray, silty, slightly phosphatic, and glauconitic. The lower part is very fine to medium grained; the upper part is very fine to very coarse grained. Shales interbedded with the sandstone in the middle part of the member are dark gray to brownish black, partly limy, silty, siliceous, and phosphatic. Shale in the lower part of the median shaly sequence includes two or three thin bentonitic(?) beds, a thin sandstone, and some hard brownish-gray dolomite beds.

Near the west end of Elk Hills (wells 555-15Z and 518-14Z, pl. 7), the Carneros Sandstone Member is about 700-950 feet thick and consists of three sandstone intervals separated by shale. These are called in descending order the $1 \mathrm{st}, 2 \mathrm{~d}$, and $3 \mathrm{~d}$ Carneros sands by petroleum geologists. The 1st Carneros sand is about 100 feet thick; the other two are each about 200 feet thick. Eastward along section AF (pl. 7), the 3d Carneros sand virtually wedges out in the vicinity of well 555-30R. It is represented only by a thin lens of siltstone and sandstone in one well $(556-25 \mathrm{R})$ to the east. The $2 \mathrm{~d}$ and $3 \mathrm{~d}$ Carneros sands extend across most of the Elk Hills oil field but grade into the Santos Shale Member short of the North Coles Levee oil field. The Gould Shale Member of the Monterey Shale rests unconformably on the Carneros Sandstone Member in well 526-30R (Adkison, 1973, pl. 1) near well 555-30R on plate 2 .

\section{MEDIA SHALE MEMBER}

Cunningham and Barbat (1932, table 1) placed the name Media Shale in print for the first time with reference to an unpublished report by May and Gilboe (1931). The undesignated and undescribed type locality was assumed by Heikkila and McLeod $(1951$, p. 8$)$ to be located on Media Agua Creek west of the McDonald oil field (fig. 34). Dibblee (1973, p. 23) designated the type section for the Media Shale Member as being in sec. 9, T. 29 S., R. 20 E., on Zemorra Creek (fig. 33). Woodring, Stewart, and Richards (1940, p. 130) had previously described this section as a 920 -foot interval of dark silty partly foraminiferal shale that includes a 50-foot cherty shale interval about 200 feet below the top, a hard 5-foot sandstone bed about 160 feet below the top, and a few zones of calcareous concretions scattered throughout. Northwestward toward the Bitterwater Creek area, the middle part becomes limy and includes numerous hard limestone beds averaging 3 feet in thickness, and the upper part becomes more siliceous (Heikkila and MacLeod, 1951, p. 9, 10). Foss and Blaisdell (1968, p. 39), in discussing outcrops along the west side of the San Joaquin Valley, stated that the lithology of the Media ranges from platy tan silty shale to light-colored siliceous shale, whose most characteristic outcrop feature 
is the presence of numerous 3 -foot-thick buff-colored limestone beds. According to Adkison (1973, p. 26), the Media Shale Member in well 555-30R at Elk Hills is about 150 feet thick and consists almost entirely of medium-dark-gray partly limy hard shale, the lower part of which is slightly phosphatic and the middle and upper parts mostly siliceous.

The thickness of the Media Shale Member in most places at Elk Hills and vicinity ranges from about 150 to 560 feet. An 800-foot interval was drilled in well 55628R near the middle of the Elk Hills field, but steep dips measured in beds about 2,000 feet above the Media in this well suggest that the true thickness may be about half the drilled interval. The Media is apparently missing from well $526-30 \mathrm{R}$ where the Carneros is overlain unconformably by the Gould Shale Member of the Monterey Shale (Adkison, 1973, p. 25). It conformably overlies the Carneros Sandstone Member in the Railroad Gap and Elk Hills fields and overlies the Santos Shale Member in the North Coles Levee field, where the Car: neros is absent. The Media is overlain by the Gould and Devilwater Shale Members of the Monterey Shale from Railroad Gap across Elk Hills to North Coles Levee (pl. 7): The Buttonbed Sandstone Member, placed at the top of the Temblor Formation farther north at Carneros Creek by Anderson (1905, p. 170), is not present at Elk Hills. This sandstone, studded with mollusks and buttonlike echinoids (Scutella merriami), is said by Heikkila and MacLeod (1951, p. 10) to be "a highly transgressive unit which overlaps the Media and other underlying members of the Temblor." They also pointed to areas where the Buttonbed Sandstone Member rests directly upon the Eocene Point of Rocks Sandstone. Foss and Blaisdell (1968, p. 39) regarded the Buttonbed as the basal part of the Monterey sequence. Dibblee (1973, p. 23) stated that the Buttonbed Sandstone Member "may be a transgressive basal sandstone of the Monterey Shale, as indicated by an unconformity locally at the base in the Shale Hills area (Heikkila and MacLeod, 1951, p. 10) and at Devils Den. In other areas, this sandstone member or its equivalent is not differentiable from the underlying sandstone facies of the Temblor Formation." The wells along section AF (pl. 7) offer no evidence for or against an unconformity at the top of the Media Shale Member.

\section{$\because$ ROCKS OF MIDDLE AND LATE MIOCENE AGE} MONTEREY SHALE

About 120 years ago, Blake (1855, p. 331) used the term "Monterey Formation" in a general way to indicate a type of rock exposed on a hill about 2 miles southeast of the town of Monterey. Since then the name Monterey has been used by geologists in a stratigraphic sense to indicate a dominantly siliceous and diatoma- ceous shale of Miocene age in the Coast Ranges of California. Eldridge (1903, p. 306-31:0), one of the early workers along the west side of the San Joaquin Valley, described the formation near Coalinga, McKittrick, and Sunset. About 60 years after Blake's first mention, a type locality at Monterey and its molluscan fauna were described by Martin (1912, p. 143-150), who estimated the shale to be over 2,000 feet thick. The usage of Monterey in the literature up to this time was reviewed critically by Louderback (1913, p. 193-232). The type locality and its fossils were redescribed about 16 years later by Hanna (1928, p. 969-983).

The only complete continuously exposed section of Monterey Shale along the west side of the San Joaquin Valley is in a homoclinal fold along Chico Martinez Creek (Dibblee, 1973, p. 27). (See fig. 34 for general location.) This section was described and divided into 11 units from base to top by Woodring, Stewart, and Richards (1940, p. 125). They recommended the term Monterey Shale for "Miocene strata in the Coast Ranges characterized by hard siliceous shale and soft shale containing microscopic siliceous fossils, regardless of varying chronologic relations of these strata within the Miocene, in accordance with the principle that a formation need not be the same age from place to place."

During the extensive geological mapping and exploration of the southern San Joaquin Valley from 1930 to 1940, petroleum geologists divided the Monterey Shale along the west side into members partly on the basis of lithology and partly on the basis of foraminiferal assemblages that could be traced not only along the outcrop but also in sample logs of wells in the valley. The extent of these members in the subsurface is well illustrated by the correlation sections of Church, Krammes, and others (1957, 1959). The members identified by petroleum geologists in the outcrops along Chico Martinez Creek are mapped and described in two guidebooks of the San Joaquin Geological Society (McMichael and others, 1959, p. 6, 7, 13; Foss and Blaisdell, 1968, p. 37-38; Elliott and others, 1968, p. 110-112, 114). These members were designated in ascending order, the Gould Shale, Devilwater Silt, McDonald Shale, Antelope Shale, Chico Martinez Chert, and Chico Martinez (Belridge) Diatomite Members. The McDonald Shale, Antelope Shale, and Chico Martinez Chert Members become lithologically indistinguishable northwestward from Chico Martinez Creek and merge into the McLure Shale Member, a unit first defined by Henny (1930, p. 403-410) as a formation south of Reef Ridge and near Sunflower (McLure) Valley.

Dibblee (1973, p. 27) designated exposures along Chico Martinez Creek (fig. 34) as the reference section for the Monterey Shale and its members northeast of the San Andreas fault. Principally on the basis of gen- 
eral lithology, bedding, and weathering characteristics, he mapped and adopted the following members, in ascending order: the Gould Shale, Devilwater Shale, McLure Shale, and Belridge Diatomite Members. This terminology is only partly suitable for the Monterey Shale drilled at Elk Hills. In wells at Elk Hills and nearby oil fields, the McDonald shale of local usage, correlative with the lower part of the McLure Shale Member in the Temblor Range, is a distinct lithologic unit. The Belridge Diatomite Member cannot be recognized in the upper part of the Monterey at Elk Hills.

The Monterey Shale beneath Elk Hills is readily divided into the Gould and Devilwater Shale Members, undifferentiated, the McDonald shale of local usage, and the Elk Hills Shale Member. The Elk Hills Shale Member, named by Adkison (1973, p. 29), includes equivalents of the Antelope shale and overlying units of subsurface usage to the north. It corresponds to the upper part of the McLure Shale and the Belridge Diatomite Members to the west.

The Monterey Shale, penetrated by wells in the Elk Hills and adjacent oil fields, is a fine-grained clastic sequence of diatomaceous or silty claystone, and diatomites and siliceous shales containing sandstone lenses (Adkison, 1973, p. 30-39). Its thickness ranges from about 2,100 feet in well 555-15Z, Railroad Gap, to about 4,100 feet in well 67-29T, North Coles Levee (pl. 7). A thicker interval $(4,800 \mathrm{ft}$.) was drilled in well 526-28R, Elk Hills, but the steep dips recorded indicate that the true thickness is much less.

GOULD AND DEVILWATER

SHALE MEMBERS, UNDIFFERENTIATED

The Gould Shale Member, first mentioned by Cunningham and Barbat (1932, table 1) and later defined by Barbat (1932, p. 611-612), has as its type locality the exposure from Chico Martinez Creek (NE⿺𠃊1/4, sec. 9, T. 29 S., R. 20 E., Kern County) southeastward for a distance of 2 miles (Dibblee, 1973, p. 28) (fig. 34). It was named for nearby Gould Hill, about 22 miles northwest of Elk Hills. According to Barbat (1932, p. 611-612), the Gould Shale at Gould Hill consists of 220-230 feet of shale overlying his Button bed member of the Temblor Formation and underlying the Valvulineria californica zone of the Monterey Shale. Along Chico Martinez Creek, the Gould Shale Member, about 550 feet thick, consists of hard tan to light-brown platy partly limy but mostly siliceous shale that contains Siphogenerina branneri, a microfossil found in equivalent beds at Elk Hills. The siliceous shales serve to distinguish it from the overlying Devilwater Shale Member in the Chico Martinez Creek area, but throughout most of the region the separation cannot be made consistently. In the
Temblor Range, Dibblee $(1973$, p. 28,29$)$ applied the name Gould Shale Member to a predominantly siliceous shale sequence, mainly of middle Miocene age, in the Monterey Shale. He recognized that the upper part of this sequence in the southeastern part of the range probably is equivalent in age to the Devilwater Shale Member at Chico Martinez Creek.

The Devilwater Shale Member was initially designated the Devilwater Silt, presumably for exposures in Devilwater Creek (fig. 34) 30 miles northwest of Elk Hills (Bailey, 1939, p. 66-71; Foss and Blaisdell, 1968, p. 38). Prior to this, these beds had been referred to as the Valvulineria californica zone, a foraminiferal zone at the base of the Monterey Shale in its type area (Goudkoff, 1931, p. 840). Exposures of the Devilwater Shale Member along Chico Martinez Creek are about 1,180 feet thick and consist mainly of massive gray, buff, and brown silty shale and siltstone beds, mostly clayey but partly siliceous and limy, with abundant nodules. These beds contain a distinctive microfauna of which Valvulineria californica is regarded as most diagnostic. Dibblee (1973, p. 29) regarded the type Devilwater Shale Member at Chico Martinez Creek as the predominantly clayey shale above predominantly siliceous shale of the Gould Shale Member. The separation of the two members on the basis of lithologic characteristics is so uncertain that the two members are not differentiated in most well logs of this report.

Along section AF (pl. 7), the thickness of the Gould and Devilwater Shale Members, undifferentiated, ranges from 109 feet in well 556-25R, Elk Hills, to 655 feet in well.67-29T, North Coles Levee. A greater thickness (863 ft.) recorded in well 526-26R is exaggerated because of the steep dip of the strata in this well.

Although the Gould and Devilwater Shale Members cannot be consistently separated by means of electric logs at Elk Hills, the units have been individually identified in wells 555-30R and 538-19R by a combination of paleontologic and lithologic data from samples (E. E. Glick, written commun., 1969) and the electric-log characteristics. The Gould is 300 and 150 feet thick in these wells, respectively, and consists mostly of medium- to dark-gray silty partly diatomaceous partly phosphatic shale with minor amounts of light- to darkbrownish-gray siltstone. Some thin greenish- to bluish-gray bentonite layers are present. The foraminifer Siphogenerina branneri is abundant in the interval. The Devilwater is 190 and 220 feet thick in these wells, respectively, and consists mainly of medium-light-gray slightly limy siltstone and darkgray partly siliceous slightly limy shale containing a few thin layers of greenish-gray bentonite. The foraminifer Valvulineria californica is present near the top of the unit. 
The Gould Shale Member has also been identified in well 526-30R by Adkison (1973, p. 30), who described it as medium-dark-gray and brownish-gray shale with a few thin beds of limestone and sandstone in the upper half. He noted that the lower half is almost entirely siliceous shale and the upper half is partly siliceous and partly limy. R. S. Beck (written commun., 1969) identified the foraminifers Siphogenerina branneri, Valvulineria robusta, and Hemicristellaria beali from the upper part and placed the upper contact at the top of shale beds containing Siphogenerina branneri. Adkison $(1973$, p. 32) was unable to identify the overlying shale other than Devilwater or McDonald because of poor samples that resulted from mechanical difficulties during the drilling of the interval.

\section{MCDONALD SHALE OF LOCAL USAGE}

Cushman and Goudkoff $(1938$, p. 1) applied the name McDonald Shale to outcrops of massive brown silty shale containing the foraminifer Pulvinulinella gyroidinaformis southwest of the McDonald oil field (fig. 33) about 27 miles northwest of Elk Hills. The McDonald later was more fully described and mapped along the Temblor Range southwest of McKittrick by Simonson and Krueger (1942, p. 1616, 1617, fig. 8), who reported a diagnostic foraminiferal fauna in the beds. Dibblee (1973, p. 28) did not recognize the McDonald as a stratigraphic unit along the Temblor Range because these rocks and the overlying rocks, which he designated the McLure Shale Member, are mostly siliceous shale difficult to distinguish from each other in weathered outcrops.

In the subsurface of Elk Hills, shale occupying the interval between the underlying Gould and Devilwater Shale Members and the overlying Elk Hills Shale Member can be identified by electric log characteristics. The name "McDonald shale," commonly applied to this interval by petroleum geologists, is retained as an informally named unit in the subsurface. A standard reference section for this unit is designated as the strata between the depths of 7,630 and 7,940 feet in well 53819R. The lithology and microfauna of the McDonald in this well are described in the following sectionlithologic descriptions of drill cuttings by E. E. Glick; paleontologic identifications by R. S. Beck.

$$
\text { Lithology and microfossils }
$$

Depth $(f t)$

Shale, dull medium-brownish-gray, faintly banded, slightly limy, slightly micaceous; Uvigerina subperegrina few, Robulus sp. fragment, Globigerina bulloides few, Buliminella subfusiformis rare, Bulimina? sp. few, Gyroidina rotundimargo rare, Nonionella sp. rare, Bolivina? sp. rare, radiolaria rare, Cyclammina? sp. fragment, Bathysiphon? sp. fragment, Nodosaria? sp. fragment, fish remains rare
Lithology and 'microfossils

Shale, dull medium-brownish-gray, limy; Uvigerina hootsi rare, Bulimina ovata few, Bolivina cf. $B$. parva rare, Globigerina bulloides rare
le, as above, but more banded and siliceous; Uvigerina hootsi common, Bolivina parva few, Bulimina ovata few, Robulus mohnensis rare, Globigerina bulloides rare

Shale, dull dark-brownish-gray, slightly limy to very limy, micaceous; Uvigerina hootsi abundant, Bulimina ovata few, Globigerina bulloides few, Bolivina parva few, Nonionella miocenica few, Cassidulina? cf. C. monicana rare, Buliminella subfusiformis rare, Dentalina? fragment

ale, as above but trace brownish-gray chert Uvigerina hootsi common, Virgulina californiensis grandis rare, Bulimina ovata rare, Robulus mohnensis rare, Bolivina parva rare, Buliminella subfusiformis rare, Cassidulina? cf. C. monicana

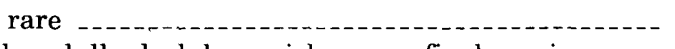

Shale, dull dark-brownish-gray, finely micaceous; Pulvinulinella? cf. gyroidinaformis rare, Uvigerina hootsi few, Cassidulina monicana rare, Bolivina parva few, Virgulina californiensis grandis rare, Nonionella sp. fragment Uvigerina hootsi rare, Bulimina ovata rare, Globigerina bulloides rare, Bolivina parva rare, Nonionella sp. fragment, fish remains rare

Shale, as above; dull medium-brownish-gray limy shale; Uvigerina hootsi rare, Bolivina sinuata alisoensis few, Cancris? cf. C. brongniaritii rare, Cassidulina cf. C. monicana rare, Bulimina ovata rare, Globigerina bulloides rare _......-.

Shale, medium-dark-gray to dark-brownish-gray, slightly limy, finely micaceous; pyrite; Uvigerina hootsi few, Bolivina sinuata alisoensis rare, Cassidulina monicana few, Buliminella subfusiformis rare, Bolivina parva rare, Cancris? cf. $C$. brongniartii rare, Bulimina? sp. fragment, Baggina californica rare

Shale, dull dark-brownish-gray, slightly limy, finely micaceous; slickensides; pyrite; trace light-brown limy dolomite; Uvigerina hootsi few, Globigerina bulloides rare, Bulimina ovata rare, Virgulina californiensis grandis rare, Bolivina parva rare -- 7,870-7,890

Shale, as above; trace light-brownish-gray siliceous banded chert; Uvigerina hootsi rare, Cassidulina monicana rare, Bulimina ovata rare, Cancris brongniartii rare, Bolivina cf. $C$. parva rare, fish

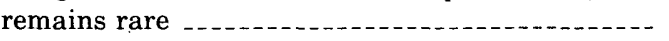

Shale, dark-gray to dark-brownish gray, faintly banded, slightly limy, siliceous, micaceous, hard; trace pyrite; Pulvinulinella gyroidinaformis rare, Uvigerina hootsi rare, Bolivina sinuata alisoensis rare, Globigerina bulloides rare, Bulimina ovata rare, Bolivina cf. parva rare, Virgulina cf. C. californiensis grandis rare

$7,910-7,940$

In wells on cross section AF (pl. 7), the McDonald is mainly a gray to brown cherty claystone and is 77 to at least 593 feet thick. The thickness of 1,600 feet shown in well $526-28 \mathrm{R}$ must be disregarded as a true stratigraphic thickness because of nearly vertical dips re- 
corded in this interval. The McDonald is marked in the wells at Elk Hills by the presence of the microfossils $P$. gyroidinaformis, Uvigerina hootsi, Bolivina parva, and Cassidulina monicana, which R. S. Beck (written commun., 1969) considers characteristic of the McDonald elsewhere in the San Joaquin Valley.

Samples of the McDonald interval are available from only three wells at Elk Hills. These are wells 538-19R, $555-30 \mathrm{R}$, and $526-30 \mathrm{R}$, all in the western part of the oil field. The interval for well 538-19R has been described in the preceding sections and is the reference section for Elk Hills. The lithologic sequence in the other two wells is similar except that thin beds of graygreen bentonitic shale were noted in the lower 100 feet of the McDonald in these wells. In addition, the McDonald is overlain in well $526-30 \mathrm{R}$ by light-gray fine- to medium-grained sandstone about 20 feet thick that contains scattered coarse quartz grains, a few feldspar grains, and a trace of glauconite. Adkison $(1973$, p. 33,34$)$ suggested that the relative coarseness of this sandstone may indicate a disconformity of at least local extent.

\section{ELK HILLS SHALE MEMBER}

The Elk Hills Shale Member is a name formally applied by Adkison (1973, p. 34) to the predominantly siliceous shale sequence between the top of the McDonald shale of local usage and the base of the Reef Ridge Shale in wells at Elk Hills. The new name was proposed in preference to extending Noble's (1940, fig. 1) name Antelope shale from the north. This was done to avoid the confusion of meanings surrounding the use of the name Antelope Shale (Noble, 1940, fig. 1; Simonson and Krueger, 1942, p. 1611, 1612; Church and others, 1959; McMichael and others, 1959, p. 13, 14) and to maintain the McDonald as a useful, distinct shale unit in the subsurface.

At Elk Hills, the interval referred to the Elk Hills Shale Member was correlated by Lorshbough (1967, pls. $4,6)$ with his Antelope Shale Member, which constitutes the middle and upper parts of the Monterey Shale in outcrops near Antelope Valley (fig. 33) in northwestern Kern County. The unit operator at Elk Hills has used the term "Antelope Shale" for the lower part of Lorshbough's Antelope Shale Member and the term "Brown shale" for the upper part.

Dibblee (1973, p. 28) rejected the name Antelope for shale at Chico Martinez Creek (fig. 38) principally because he was unable to differentiate it from shale of the McLure Shale Member. He divided the Monterey above the Devilwater Shale Member into the McLure Shale Member and the Belridge Diatomite Member. The Belridge is not recognizable in wells at Elk Hills, and in other places such as the Belridge oil field, some geologists regard it as equivalent to the lower Reef Ridge Shale rather than the upper part of the Monterey (Barbat and Johnson, 1934, p. 9; Siegfus, 1939, p. 25; Foss and Blaisdell, 1968, p. 36, 37).

The type section set up by Adkison (1973, p. 34) for the Elk Hills Shale Member consists of the interval between drilled depths of 6,035 and 9,540 feet in well 526-30R. The true stratigraphic thickness corrected for the dip of the strata in the well is about 3,000-3,100 feet. A detailed description of the lithology and paleontology is given in a report on the lithologic characteristics of upper Oligocene and Miocene rocks drilled at Elk Hills (Adkison, 1973, p. 34-39).

The thickness of the Elk Hills Shale Member ranges from 1,779 to 3,282 feet along section $\mathrm{AF}$ (pl. 7) from Railroad Gap to North Coles Levee. No conspicuous unconformity above or below is apparent, although a local disconformity due to onlap of the Reef Ridge may be present at the top in the vicinity of Railroad Gap. The member consists mainly of gray siliceous shale and siltstone but has some gray micaceous claystone in the lower part and brown dolomitic diatomaceous shale in the upper part. In some wells, it contains thick oil-bearing sandstone lenses that are known as the Asphalto or $24 Z$ sand (pl. 8), the $26 \mathrm{R}$ sand (pls. 9, 10) and the Main Body B sand (pls. 11, 12). The Elk Hills Shale Member is divided, in upward order, into the E, DD, D, $\mathrm{C}, \mathrm{B}, \mathrm{A}$, and $\mathrm{N}$ zones (fig. 33). These are stratigraphic zones set up for the most part in accordance with the oil and gas zones of the Elk Hills Engineering Committee (1957b, fig. 1). (See section "Oil-field terminology.") Several persistent horizons within these zones are recognizable on the electric logs. These include the top of the Antelope shale as used by the unit operator, which is within the top 150 feet of the A zone, and the $Q$ and $N$ horizons within the $\mathrm{N}$ zone. The megafossil Pectin peckhami is found in abundance in samples of the A zone. The top of the Elk Hills Shale Member is marked by an upward change from predominantly brown siliceous shale to gray partly sandy mostly nonsiliceous shale at the top of the $\mathrm{N}$ zone.

$E$ zone.-The $\mathrm{E}$ zone, lowermost of the divisions, is 825 feet thick in well 526-30R and consists mainly of shale, siltstone, and sandstone. The shale is mostly medium to dark gray; siliceous and cherty shale is abundant in the lower part. The siltstone, mainly in the middle and upper parts, is medium light to dark gray and partly sandy. Several thin beds of fine-grained sandstone are present in the middle and upper parts, and a 23-foot bed of medium-grained sandstone marks the base. The grain size of the basal sandstone increases downward, and the lower part includes some coarse and very coarse grains. Two thin beds of argillaceous limestone lie in the lower middle part, and a thin bed of 
light-gray to yellowish-brown flaky shale lies about 140 feet above the base of the zone. R. S. Beck (written commun., 1969) reported rare specimens of Haplophragmoides(?) sp. and a few indeterminate fossil fragments in samples from the $\mathrm{E}$ zone. The contact between the $\mathrm{E}$ zone and the overlying DD zone is marked by an upward change from sandy siltstone to shale. The top of the $\mathrm{E}$ zone is readily identified on electric logs across the Elk Hills oil field. The thickness along section AF (pl. 7) ranges from about 230 feet in well 538-19R in western Elk Hills to about 885 feet in well 67-29T in North Coles Levee. The zone wedges out westward along the western part of Elk Hills, probably owing to onlapping depositional conditions.

$D D$ zone-The DD zone in well $526-30 \mathrm{R}$ is 248 feet thick and is composed of brown to dark-gray silty shale, dark-gray siltstone, and in the lower half, some light- to medium-gray silty sandstone. Siliceous beds are abundant. A thin bed of limestone and one of dolomite are included in the lower and middle parts, respectively. Shale at the base of the zone has a low resistivity and appears in samples to be bentonitic. R. S. Beck (written commun., 1969) questionably identified the diatom Coscinodiscus sp. in the middle part and Bolivina sp. and Globigerina bulloides in the upper part. An upward change from dark gray and grayish-black shale to brownish-gray sandy siliceous siltstone marks the contact of the DD and overlying D zones. The DD zone is characterized by its generally low resistivity and can be identified with confidence on most electric logs of the field. It is thickest, about 260 feet in well $555-30 \mathrm{R}$, in the west half of the Elk Hills field. It thins eastward to about 100 feet in the eastern Elk Hills field and the North Coles Levee field. Westward it is only 25 feet thick in well 518-14Z on the west edge of Elk Hills field and wedges out before reaching Railroad Gap well $555-15 Z$. The western thinning appears to be the result of depositional onlap.

D zone-The D zone, which in well 526-30R is 661 feet thick, consists principally of brown to gray diatomaceous siltstone and brown to gray diatomaceous, siliceous, and silty shale. Numerous brown to black chert layers or nodules and several thin beds of dolomite are present. Some thin sandstone layers are present in the lower half. R. S. Beck (written commun., 1969) found Haplophragmoides sp., Globigerina bulloides, Radioaria, and some echinoid spines in samples from the zone. The upper limit of the $\mathrm{D}$ zone is marked by an upward change from siltstone to shale. This is readily apparent on the self-potential curve of electric logs. The thickness of the D zone along section AF (pl. 7), uncorrected for dip, ranges from about 275 to 675 feet. The zone extends the entire length of the Elk Hills oil field. It is about 340 feet thick in well 555-15Z in the Railroad Gap oil field and about 450 feet thick in well $67-29 \mathrm{~T}$ in the North Coles Levee oil field.

$C$ zone.-The $\mathrm{C}$ zone, which in well $526-30 \mathrm{R}$ is 367 feet thick, is gray silty partly siliceous shale that includes some interbedded diatomaceous siltstone. Thin sandstone and dolomite layers are scattered throughout the sequence. As shown on sections $\mathrm{AB}, \mathrm{BC}$, and $\mathrm{CD}$ (pls. 8-10; figs. 35, 36), the $\mathrm{C}$ zone along with overlying $\mathrm{B}, \mathrm{A}$, and $\mathrm{N}$ zones locally contains sandstone bodies known in oil-field terminology as the $24 \mathrm{Z}$ and $26 \mathrm{R}$ sands. These sandstone bodies are regarded as channelturbidites and are discussed separately in this report. Fossils are rare in the C zone. R. S. Beck (written commun., 1969) found Haplophragmoides sp. and Globigerina bulloides in a few scattered samples and also a few fragments of Bathysiphon sp. in samples in the upper part. The top of the $\mathrm{C}$ zone is readily identified on the electric log, which reflects an upward change from shale to sandstone at this point. Along section $\mathrm{AF}$ (pl. 7), the $\mathrm{C}$ zone ranges in thickness from about 230 feet in well 562-31S near the center of Elk Hills to about 535 feet in well 67-29T in North Coles Levee. The thickness of the $\mathrm{C}$ zone and the areal distribution of the $24 \mathrm{Z}$ and $25 \mathrm{R}$ sand bodies are shown on plate 18 . The thickness of the $\mathrm{C}$ zone generally reflects the local structure (pl. 4); it ranges from about 200 feet on the crests of the Western and Eastern anticlines to more than 700 feet on the flanks. The thickness lines on the Western anticline do not conform to the structure contours as well as those on the Eastern anticline. The thickness lines on the Eastern anticline are generally subparallel to the structure contours, although the axis of maximum thinning is offset slightly northward from the structural axis. This suggests more active growth of the Eastern anticline than the Western anticline at this time. The distribution of the sand bodies also suggests growth of the Eastern anticline contemporaneously with deposition. The $24 \mathrm{Z}$ sand cuts across the Western anticline, whereas the 26R sand follows the southwest flank of the Eastern anticline. If these deposits are channel turbidites, uplift of the Eastern anticline may have deflected the flow of the $26 \mathrm{R}$ sand into the deeper parts of the basin.

B zone.-In well 526-30R, the $\mathrm{B}$ zone is 379 feet thick and consists primarily of interbedded brown to gray siliceous diatomaceous siltstone, brown to gray silty mostly siliceous shale, and gray very fine grained silty sandstone. The sandstone beds are less than 10 feet thick, and some beds contain black phosphatic grains commonly called "sporbo." As noted for the $\mathrm{C}$ zone, the uniformity of the B zone is interrupted in the western and central parts of the field by the $24 \mathrm{Z}$ and $26 \mathrm{R}$ sandstone bodies (pls. 8-10). In addition the B zone in the eastern part of the Elk Hills field and in the North 


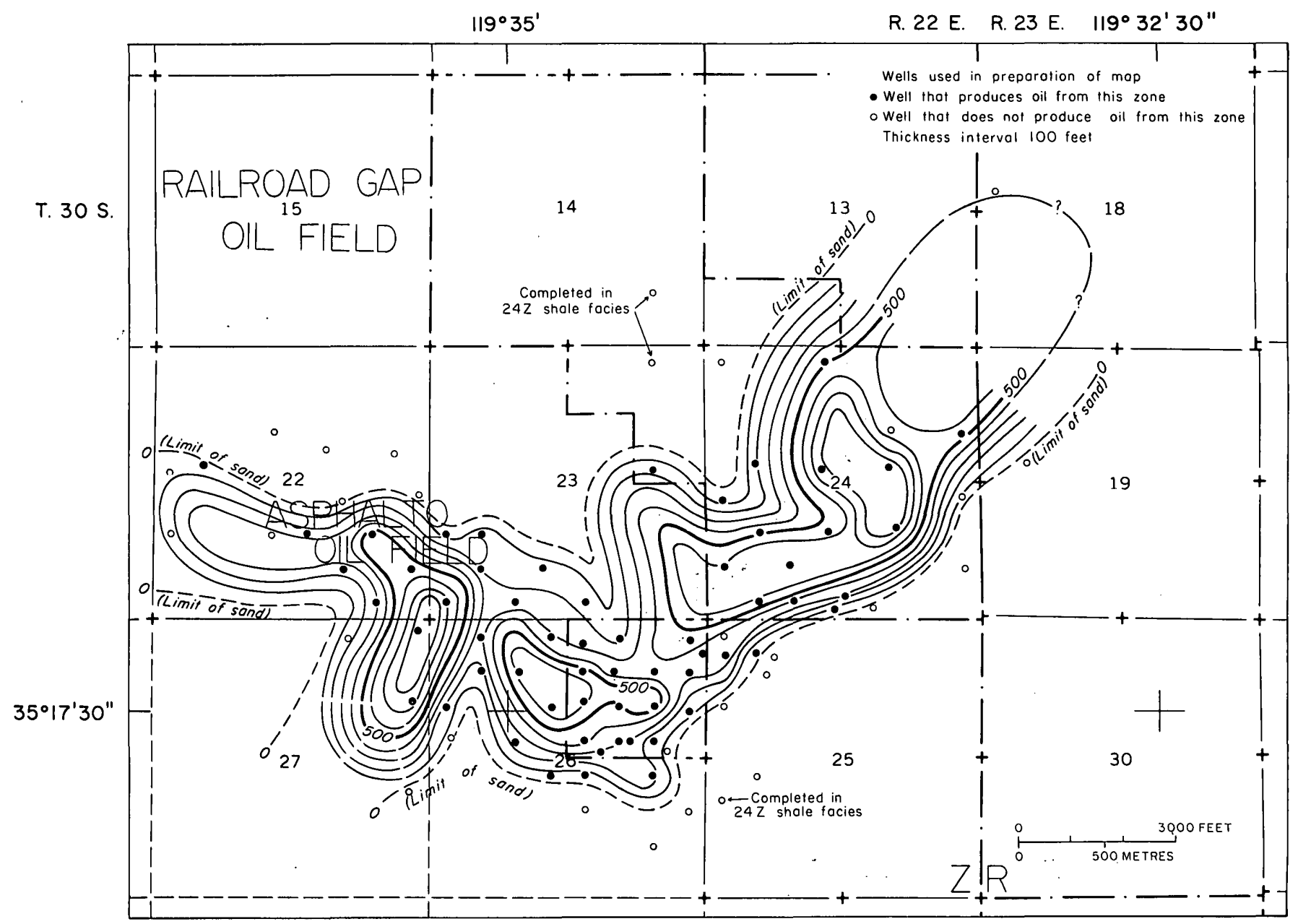

FIGURE 35.-Thickness of 24Z (Asphalto) sand facies in the Asphalto oil field and western part of the Elk Hills oil field.

Coles Levee field contains several lenses of the Main Body $\mathrm{B}$ and Western sands, which may be basin-floor turbidites (Foss, 1972, p. 41). R. S. Beck (written commun., 1969) identified foraminifers Haplophragmoides sp., Bathysiphon sp., Globigerina bulloides, Uvigerina(?) sp., Gyroidina rotundimargo, diatoms including Coscinodiscus sp., and spherical Radiolaria. A change upward from siltstone to fairly soft gray shale at the $\mathrm{B}$ and $\mathrm{A}$ zone contact marks the contact but does not provide much contrast in lithology. As a result differences in electric-log characteristics are less pronounced here than at other boundaries. Along section AF, the thickness of the $B$ zone ranges from about 350 feet in well 555-15Z, Railroad Gap, to about 610 feet in well 67-29T, North Coles Levee. The thickness of the B zone (pl. 18); which conforms to the structure (pl. 4) in a general way, is about 300 and 400 feet on the tops of the Western and Eastern anticlines, respectively, and more than 700 feet in the intervening syncline. The axis of maximum thinning on the Eastern anticline seems to be offset slightly to the north of the structural axis as drawn on top of the Elk Hills Shale Member. The 24Z sand body coincides with a thickening of the zone across the western part of the Western anticline. The $26 \mathrm{R}$ sand body roughly coincides with a thickening trend along the southwest flank of the Eastern anticline.

A zone.-The A zone is 315 feet thick in well $526-30 \mathrm{R}$ and consists of brown to gray diatomaceous partly sandy partly dolomitic siltstone interbedded with brown to gray silty mostly siliceous shale, gray silty very fine grained sandstone in beds $1-4$ feet thick, and some thin layers of dolomite. The $24 \mathrm{Z}$ and $26 \mathrm{R}$ sand bodies interrupt the lithologic uniformity of the zone in the western and central parts of the field as shown on plates 8-10. Microfossils, which are fairly common in the lower half of the zone, include the foraminifers Haplophragmoides sp., Bolivina if. B. Vaughani(?), Bathysiphon sp., the diatom Coscinodiscus sp., and spherical Radiolaria according to R. S. Beck (written commun., 1969). The upper limit of the $A$ zone lies 


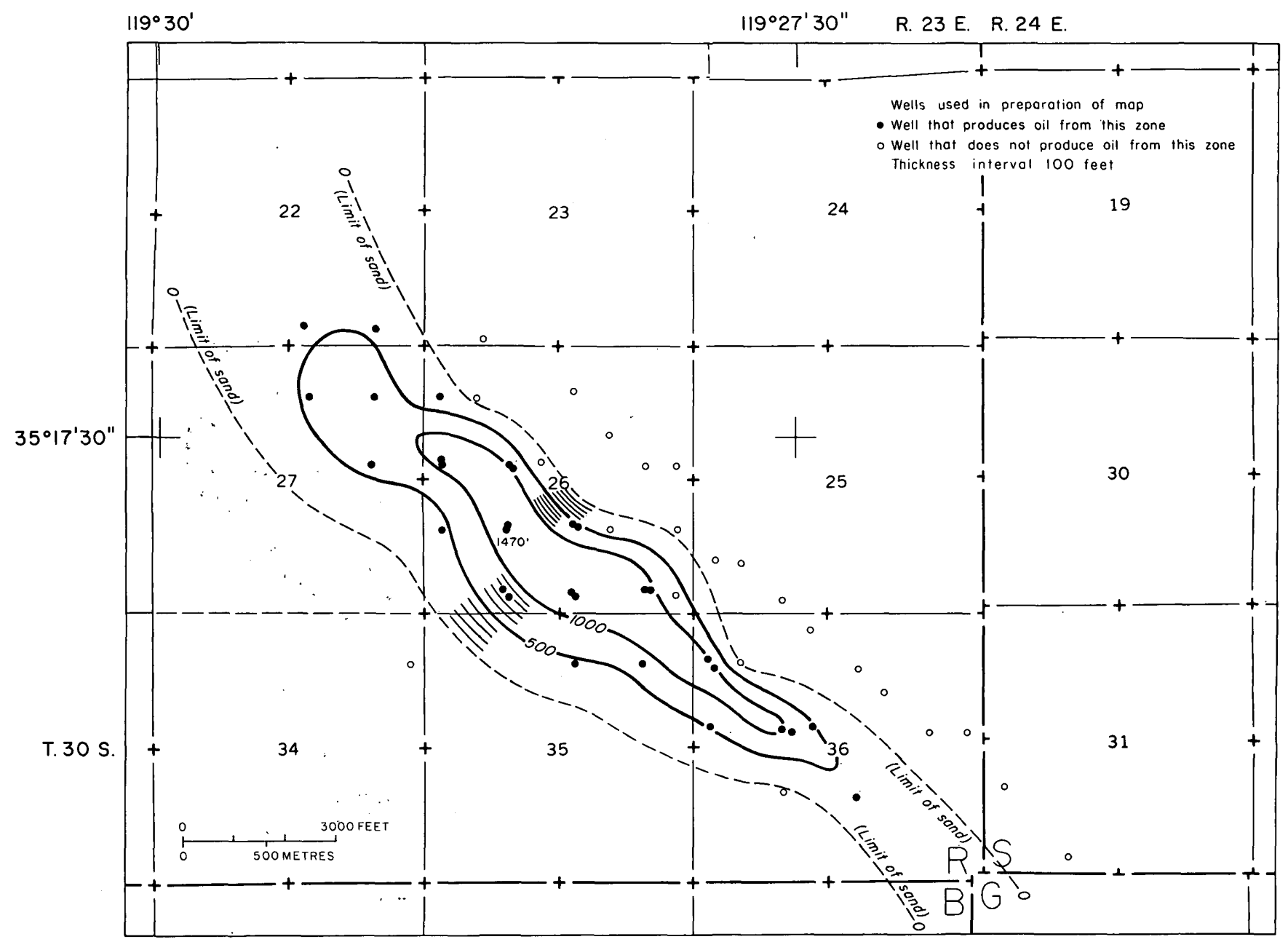

FIGURE 36.-Thickness of 26R sand facies in central part of the Elk Hills oil field.

within an alternating succession of diatomaceous siltstone and shale beds. The contact with the overlying $\mathrm{N}$ zone is defined principally by the shape of the selfpotential curve on the electric log. The A zone on section $\mathrm{AF}$ (pl. 7) ranges in thickness from about 195 feet in well 562-31S in central Elk Hills to about 475 feet in well 518-14Z in western Elk Hills. The zone has a thickness of about 215 feet to the east in well 57-29T, North Coles Levee. It is more than 800 feet thick on the flanks of the anticlines (pl. 19) in the Elk Hills field. The thickness lines outline generally the anticlinal structures, although the areas of thinnest interval do not everywhere coincide with the crests. Where the $24 \mathrm{Z}$ sand body extends across the western part of the Western anticline, the zone is 500 to more than 700 feet thick. The 26R sand body is marked by an area of thickening that trends northeastward subparallel to structure contours along the southwest flank of the Eastern anticline.

$N$ zone.-The $\mathrm{N}$ zone is the uppermost division of the Elk Hills Shale Member and is 710 feet thick in well 526-30R. It consists of brown to gray diatomaceous siltstone and lesser amounts of brown to gray silty partly siliceous shale, and gray very fine to medium-grained silty sandstone. The sandstone beds range in thickness from about 3 to 8 feet. A few thin beds of dolomite are scattered through the zone, and brown to black dense chert is present in the lower middle part. R. S. Beck (written commun., 1969) found the following microfossils in samples: Haplophragmoides sp., Ammobaculites sp., Cyclammina sp., Coscinodiscus sp., sponge spicules, and spherical Radiolaria. All but Haplophragmoides sp. were rare or few. The upper contact of the $\mathrm{N}$ zone that separates the Elk Hills Shale Member from the overlying Reef Ridge Shale is marked by an upward change from brown siliceous shale to gray nonsiliceous partly sandy shale. This change is reflected by a decrease in resistivity on the electric logs. In sections $24 \mathrm{Z}$ and $26 \mathrm{R}$ (sections $\mathrm{AB}, \mathrm{CD}$, pls. 8, 10), the $\mathrm{N}$ zone is within the upper parts of the $24 \mathrm{Z}$ and $26 \mathrm{R}$ sandstones and could not be differentiated from the underlying $A$ zone. The $Q$ horizon is an electric-log horizon generally about 250 300 feet below the top of the $\mathrm{N}$ zone and is persistent 
only in the Railroad Gap field and the western part of the Elk Hills field. The $\mathrm{N}$ horizon, another electric-log horizon, is generally less than 100 feet below the top of the zone and is consistently identifiable throughout most of the Elk Hills field, but it is not easily recognized in the Railroad Gap or North Coles Levee fields. The N horizon has been used for many years as a datum for structural maps of the Elk Hills field. The thickness of the $\mathrm{N}$ zone ranges from less than 200 feet on the high parts of the Elk Hills structure to more than 900 feet on the flanks (pl. 19). Along section AF (pl. 7), the $\mathrm{N}$ zone ranges in thickness from about 90 feet in well 562-31S in the central part of Elk Hills field to about 475 feet in well 518-14Z at the west edge of the field. The thickness pattern corresponds closely to the shape of the structure as reflected by structure contours on top of the zone (pl. 4), particularly on the Eastern anticline. The axis of maximum thinning and the structural axis seem to be about the same; a northward offset of the axes of thinning found in the older zones is not apparent for zone $\mathrm{N}$. The $24 \mathrm{Z}$ sand body coincides with an area of thickening in the $\mathrm{N}$ zone between the Railroad Gap and Elk Hills oil fields. The $26 \mathrm{R}$ sand body roughly parallels the thickness lines along the southwest flank of the Eastern anticline.

REEF RIDGE SHALE

The type locality for the Reef Ridge Shale is on the northwest side of Reef Ridge about 10 miles west of Kettleman Hills (fig. 34) in the northwest corner of Kern County. Barbat and Johnson (1933, p. 239; 1934, p. 3-5), who named the formation, described it as predominantly brown-weathering soft blue clay shale containing minor layers of sandy shale and resting disconformably on white-weathering hard brown siliceous and diatomaceous shale of the Monterey Formation. As originally defined, the lower part of the formation included brown clayey and silty shale beds previously placed in the McLure Shale by Henny (1930, p. 404). Siegfus (1939, p. 31, 32, 43) restricted the Reef Ridge to the gray (blue) shale beds.

Considerable confusion exists about the age and correlation of the upper part of the Reef Ridge. Barbat and Johnson (1934, p. 11) classed the Reef Ridge as latest Miocene and correlated it with the upper diatomite beds, or Belridge Diatomite, at Chico Martinez Creek on the basis of stratigraphic position and P. P. Goudkoff's opinion that foraminifers in the diatomite have close affinities to those in the Reef Ridge. In a study at Kettleman Hills, Goudkoff $(1934$, p. 439, 473) concluded that the microfauna in the upper Reef Ridge had Pliocene affinities. Siegfus $(1939$, p. 37, 44) considered the upper part of the Reef Ridge to be transitional between the Miocene and Pliocene. Kleinpell's opinion (1938, p. 165) that the foraminifers of the Reef Ridge have late Miocene affinities influenced Woodring, Stewart, and Richards (1940, p. 121) to assign a late Miocene age to the formation. Foss and Blaisdell (1968, p. 34) agreed with this assignment and pointed out that the Reef Ridge is truncated to the west by unconformities at the base of the Pliocene and at the base of the Tulare Formation. Dibblee (1973, p. 30), on the basis of his regional mapping, believed that the Belridge Diatomite Member is late Miocene but older than the Reef Ridge Shale. The assignment of the Reef Ridge Shale to the upper Miocene in this report follows the usage of Foss and Blaisdell (1968).

The lithology of the Reef Ridge Shale has been described for nine wells in the Elk Hills oil field, the only ones for which samples of the formation were available. The lithology of the Reef Ridge in well 526-30R reported by Adkison (1973, p. 41) is fairly typical. The formation, which is 578 feet thick in well 526-30R, consists almost entirely of gray to grayish-black silty or partly sandy shale that contains some silty to clayey sandstone beds as much as 3 feet thick. A few siliceous shale beds are present in the middle and lower parts. Brown dense dolomite layers are scattered through the sequence. R. S. Beck (written commun., 1969) found the foraminifer Haplophragmoides sp., a few diatoms including Coscinodiscus sp., Radiolaria, and fragments of fish and mollusks.

The correlation of the Reef Ridge Shale by means of electric logs from the Railroad Gap field eastward to North Coles Levee is shown on section AF (pl. 7). The thickness of the formation in wells along this section ranges from 195 feet in well 555-15Z, Railroad Gap, to 1,027 feet in well 67-29T, North Coles Levee field. Correlations along the same line but utilizing more closely spaced wells are shown on interlocking sections $\mathrm{AB}, \mathrm{BC}$, CD, DE, and EF (pls. 8-12). Differences in thickness from well to well are more apparent on these sections. A maximum thickness of almost 1,150 feet was found in wells in the eastern Elk Hills field.

The base of the Reef Ridge is placed at the lithologic change upward from predominantly brown siliceous shale in the Monterey Shale to mainly gray partly sandy mostly nonsiliceous shale. This change is generally quite apparent on the electric logs in the Reef Ridge Shale. An electric-log marker called the F horizon by the unit operator lies near the middle of the Reef Ridge Shale from the crest of the Eastern anticline (well 55625R) westward across the Western anticline to well 371-23Z: It appears near or at the base of the formation at Railroad Gap in wells 518-14Z and 586-15Z but probably is absent in well 555-15Z. The F horizon cannot be identified with confidence in the easternmost Elk Hills and the North Coles Levee fields. Thickness changes in the Reef Ridge Shale below this horizon provide evi- 
dence of depositional thinning of the formation by westward onlap and possibly a local disconformity at the base of the formation.

The thickness of the Reef Ridge Shale (pl. 20) is closely related to its structure (pl. 4). The formation is thin on the crests of the Railroad Gap and Flickinger anticlines to the west, and on the Western and Eastern anticlines of Elk Hills. It has a thickness of less than 200 feet on the crest of the Railroad Gap anticline, 400 feet on the Flickinger anticline, 300 feet on the Western anticline, and 500 feet on the Eastern anticline. The 500-foot thickness line (pl. 20) outlines the Western anticline, and the 1,000-foot-thickness line outlines the Eastern anticline. An area in which maximum thicknesses are over 1,300 feet separates the Eastern anticline from the South Coles Levee structure. The rate of thickness change is about 500 feet per mile on the broad top of the Western anticline, increasing to about 1,800 feet per mile on the steep flanks; the rate of change away from the crest of the Eastern anticline is much less-about 300-800 feet per mile. An anomalous thickening near the northwest nose of the Western anticline in the $\mathrm{NW}^{1 / 4}$ sec. $24 \mathrm{Z}$ is based on only one well that may have drilled steeply dipping beds. The anomaly cannot be explained from data at hand.

\section{ROCKS OF PLIOCENE AGE}

The classification and nomenclature of Pliocene beds beneath the Tulare Formation in the San Joaquin Valley have varied greatly since the first use of the term "Etchegoin Beds" for a 5,000- to 7,500-foot succession of clastic rocks exposed in the general vicinity of Etchegoin Ranch (fig. 34); about 20 miles north of Coalinga (Anderson, 1905, p. 178-181). Anderson termed the lower two-thirds of his Etchegoin Beds, composed mainly of bluish-gray sandstone and conglomerate, the "Etchegoin Sands" and the upper one-third, composed mainly of gray siltstone and silty claystone, the "San Joaquin Clays." Shortly thereafter Arnold and Anderson $(1908$, p. 46,$47 ; 1910$, p. 113-117) separated this sequence, mainly on the basis of a seeming unconformity, into the Jacalitos Formation below and the Etchegoin Formation above. They vaguely specified a type section for the Etchegoin Formation as a locality 9 miles north of Coalinga. (See Dibblee, 1973, p. 36.) Nomland (1917, p. 195-197) concluded from his investigations that the seemingly unconformable relation between the two units resulted from facies changes, that the lithologic and faunal differences were insufficient to warrant separation into two formations, and that the Jacalitos Formation should be abandoned. He considered the entire sequence to be the Etchegoin Group, having informal lower and upper divisions correspond- ing to the formational units that have been previously proposed.

Along the west side of the southern San Joaquin Valley in the vicinity of McKittrick (fig. 34), rocks of Pliocene age were included with some of Miocene and Pleistocene age in the McKittrick Formation by Arnold and Johnson (1910, p. 74-90). In 1917, Gester (1917, p. 208-227) split the McKittrick Formation into the Etchegoin and Tulare Formations near McKittrick, and in 1920, Pack (1920, p. 43-51) used the Etchegoin and Paso Robles (Tulare) Formations in the McKittrick Group in the Midway-Sunset region. The name McKittrick has since fallen into disuse.

In wells at Elk Hills, Woodring, Roundy, and Farnsworth (1932, p. 31-39) did not recognize the Jacalitos Formation and referred to all beds between the Maricopa Shale (Monterey Shale) and the Tulare Formation as the Etchegoin Formation. Reed (1933, p. 235, 236) treated the Etchegoin beds in the Kreyenhagen Hills (fig. 34) as a group composed of the Reef Ridge Formation ( $600 \mathrm{ft}$ thick), the Jacalitos Formation $(4,500 \mathrm{ft}$ thick), and the San Joaquin Clay $(2,000 \mathrm{ft}$ thick).

In 1933 and 1934, the original terminology of Anderson (1905, p. 178-181) was revived in studies of Kettleman Hills (fig. 34) by Gester and Galloway (1933, p. 1169,1172 ) and by Barbat and Galloway (1934, p. 477), in which they adopted the names "Etchegoin sand" and "San Joaquin Clay" with the separation made at the top of the "Upper Mulinia bed." Goudkoff (1934, p. 438-443) retained the name Jacalitos Formation for the lower part of the Etchegoin beds but independently recognized the usefulness of Anderson's San Joaquin as an upper unit of formational rank. Since then, most petroleum geologists working mainly with well data have continued the use of San Joaquin as a formation.

Woodring, Stewart, and Richards (1940, p. 114-117) adopted the name San Joaquin Formation but drew its base at the bottom of the first prominent conglomerate (Cascajo) above the "upper Mulinia zone." They referred to underlying rocks above the Reef Ridge Shale as "undifferentiated Etchegoin and Jacalitos formations." Stewart (1946, p. 105) retained the Jacalitos Formation at Reef Ridge near Coalinga and restricted the Etchegoin Formation to about 1,000 feet of blue conglomeratic sandstone and greenish-gray sandy siltstone and silty claystone below 2,000 feet of finer grained clastic rocks of the San Joaquin Formation.

In the Buena Vista Hills oil field (fig. 28) about 2 miles south of Elk Hills, McMaster's (1943, p. 517-518) recognized the Etchegoin and San Joaquin Formations in wells but did not identify the Jacalitos or its equivalent. He separated the Etchegoin and San Joaquin Forma- 
tions at the first occurrence of Mulinia densata Conrad, now known as Pseudocardium densatum (Gabb), in the well samples. At Elk Hills, Wells (1951, p. 2634) identified the Etchegoin and San Joaquin Formations in the same manner. These formations have been recognized in the southern San Joaquin Valley by most subsequent writers including Church, Krammes, and others (1959), Repenning (1960, p. 46), Foss and Blaisdell (1968, p. 36), Foss (1972, p. 40), Stanton and Dodd (1972, p. 51), and Addicott (1972, p. 68, 69).

Along the outcrops in Priest Valley near Coalinga, Rose and Colburn (1963, p. 40, 44) found that the Pliocene sequence between the Reef Ridge Shale and the equivalent of the Tulare Formation there is principally sandstone and could not recognize the San Joaquin Formation as a separate unit. Adegoke (1969, p. 28-34), in an outcrop study in the Coalinga region, did not separate the Jacalitos equivalent from the Etchegoin and recommended that the term Jacalitos Formation be abandoned. He mapped the base of the San Joaquin Formation as the base of the Cascajo Conglomerate Member throughout the region. Dibblee (1973, p. 34,36 , fig. 13) adopted the terminology proposed by Adegoke and divided the sequence into the Etchegoin and San Joaquin Formations. He described the lower two-thirds of the upper Tertiary sedimentary sequence along the east side of the southeastern part of the Diablo Range as a series of alternating friable marine sandstone and siltstone designated the Etchegoin Formation and the upper one-third as mainly marine to brackish-water mudstone designated the San Joaquin Formation. He also established the Etchegoin's type area and reference section.

Pliocene rocks at Elk Hills are referred in this report to the Etchegoin and overlying San Joaquin Formation, following the usage of Dibblee (1973). A standard reference section for Pliocene rocks at Elk Hills has been set up by Berryman (1973). He described a complete sequence of Pliocene beds cored in well 324-19R in the western part of the field and related the lithology and fossils to the electric-log characteristics. The lithology of Pliocene rocks in well 526-30R nearby has been described from well cuttings by Adkison (1973, p. 42-43, 51-62) and, along with the fossils, related to the electric $\log$ of that well. Although sample logs have been made from drill cuttings and scattered cores of Pliocene beds from 22 other wells in this study, the logs for wells 324-19R and 526-30R are the most complete and detailed.

The relative self-potential values for formations, members, and zones of Pliocene age at Elk Hills were computed, plotted on thickness maps, and contoured. Three of these maps are shown on plates 21 and 24 . The environmental implications are discussed in the following description of stratigraphic units of Pliocene age and in the depositional summary.

\section{ETCHEGOIN FORMATION}

The Etchegoin Formation was named and assigned to the Pliocene Series by Anderson (1905, p. 178-181). Although Arnold (1909, p. 45) reassigned it to the upper Miocene a few years later, subsequent paleontological studies by Merriam (1915, p. 41), Woodring, Stewart, and Richards (1940, p. 102, 103), and Adegoke (1969, p. 44-48) confirmed Anderson's original assignment of the Etchegoin to the Pliocene Series.

The standard reference section for the Etchegoin in Elk Hills and vicinity was set up by Berryman (1973) after his study of well $324-19 \mathrm{R}$, for which continuous cores are available. The formation is 2,622 feet thick in this well and divisible into two members readily identified on sample and electric logs throughout the field. These members of nearly equal thickness are a lower silty shale unit, the Tupman Shale Member, and an upper sandy unit, the Carman Sandstone Member. Both members were originally proposed and used informally in unpublished reports prepared for the Naval.Petroleum and Oil Shale Reserves Office of the U.S. Navy (J. C. Maher, R. J. Lantz, and R. D. Carter, unpub. data, 1970).

The contact between the Reef Ridge Shale of Miocene age and the overlying Etchegoin Formation of Pliocene age is placed at the base of the Olig sand zone in the Railroad Gap and Asphalto fields and in the westernmost part of the Elk Hills field (sections AB, GH, and IJ, pls. 8, 13, and 14). There the Olig sand zone consists of one to four sand bodies interbedded with shale, especially in the lower part. Eastward the sand bodies grade into a shale sequence, whose base can be traced with difficulty across Elk Hills to North Coles Levee. Adkison (1973, p. 42) noted that siliceous shale and brownish-gray shale beds are more common above than below the formational contact in well 526-30R but concluded that the general similarities of the lithologies at the contact suggest a gradational relation in that well. He noted that some geologists would include the shale in the Reef Ridge and place the upper contact at the base of a sand (of Olig sand zone), 157 feet above. Berryman (1973, p. D13) reported redeposited(?) silica and a few scattered gray well-rounded quartz pebbles in a gray shale matrix in a core from the base of the Etchegoin Formation in well 324-19R. The base of this pebbly shale is easily correlated by electric logs with the base of the Olig sand in nearby wells. These observations suggest at least a local disconformity in western Elk Hills and vicinity. Church, Krammes, and others 
(1957, 1958) showed an unconformity at the base of the Etchegoin on their regional sections.

The thickness of the Etchegoin along line AF across Elk Hills (pls. 8-12) ranges from 1,720 feet in the Railroad Gap field (well 555-15Z, pl. 8) to 3,480 feet in eastern Elk Hills (well 368-25S, pl. 12). In the Railroad Gap and Asphalto fields and in the western part of Elk Hills (pls. $8,13,14$ ), the base of the formation is the base of the Olig sand zone, a series of sand lenses. Eastward along line AF (pls. 8-12), the sand zone thins rapidly as the sand bodies wedge out into shale. The Olig sand zone is not present east of well $555-30 \mathrm{R}$, but the contact between the Etchegoin and the underlying Reef Ridge can be traced with confidence by means of electric-log characteristics to the eastern limit of Elk Hills and with somewhat less confidence into the North Coles Levee field. The contact seems to be gradational with little evidence of unconformable relations in most of the area, although a slight disconformity may be present in the western part beneath the Olig sand zone. The contact between the Etchegoin and the overlying San Joaquin Formation is placed at the top of the Mulinia electric-log horizon. Barbat and Galloway (1934, p. 482) believed that the upper Mulinia fossil zone marks a widespread change in lithology and fauna.

The thickness distribution of the Etchegoin Formation (pl. 20) corresponds closely to the structural relief of the underlying Reef Ridge Shale. The Etchegoin is thin along the crests of the Western and Eastern anticlines of Elk Hills and on the anticlinal structures in the Railroad Gap field, North and South Coles Levee fields, and the Flickinger anticline in sec. 25Z. Faults in the Reef Ridge Shale seem to have affected the thickness patterns in sec. 30R on the Western anticline and secs. $26 \mathrm{R}$ and $34 \mathrm{~S}$ on the Eastern anticline. The Etchegoin Formation is 2,100-2,400 feet thick on the top of the Western anticline and 2,000 feet thick on the Eastern anticline. The rate of thickening away from the axes of the two principal anticlines ranges from 1,000 to 1,750 feet per mile. Available well data shows the greatest rate of thickening on the northeast flank.

TUPMAN SHALE MEMBER

The type section of the Tupman Shale Member, near the community of Tupman (fig. 34) at the east end of Elk Hills, was set up from continuous cores in well 324-19R (pl. 14) between the depths of 3,387 and 4,717 feet (Berryman, 1973). In that well, the 1,330-foot-thick sequence of Tupman consists mainly of olive-gray silty shale. The lower part, 517 feet thick, is composed mostly of slightly siliceous olive-gray silty shale containing thin layers, 1-3 inches thick, of gray dense silty carbonate rocks, mostly siderite. The base is marked by a 9-foot-thick shale bed in which redeposited silica and a few well-rounded gray quartz pebbles as much as half an inch in diameter are notable. The base of this pebbly shale is readily correlated with the base of the Olig sand in nearby wells. The upper part, 813 feet thick, consists mostly of light-olive-gray silty shale with scattered thin layers of sandstone, siltstone, and siderite, and abundant black phosphate pellets. The pellets are well rounded and sand sized and have been identified by Galliher (1931, p. 257-269) as impure collophane.

The Olig sand zone is an interval of very fine to coarse-grained sandstone near the base of the member at the west end of the field. Sandstones in the Olig sand zone wedge out eastward into siltstone and shale of the Buliminella silt zone less than 2 miles east of the west boundary of the Naval Reserve (pls. 8, 9). The contact of the Tupman and the overlying Carman Sandstone Member is marked by a decided change in lithology from predominantly shale to siltstone and interbedded sandstone above and a decided upward increase in the numbers and species of megafossils.

The Tupman Shale Member is 755-1,855 feet thick along line AF (pls. 8-12). The thickness distribution and relative self potential of the Tupman Shale Member is illustrated by plate 21. Areas where the member is thin correspond closely to the higher parts of the structures. The member is $800-1,100$ feet thick along the crests of the principal anticlines, and thicknesses of more than 2,000 feet have been drilled low on the flanks. Relatively thin intervals of Tupman appear to reflect the underlying structure in the North and South Coles Levee fields, the Railroad Gap field, and the Flickinger anticline in sec. $25 \mathrm{Z}$ as well as at Elk Hills. A maximum thickening rate of about 1,100 feet per mile has been mapped on the steep northwest flank of the Eastern anticline.

Variations in relative self potential suggest a systematic decrease in average porosity and presumably in average grain size of the Tupman from west to east in the Elk Hills area: Coarser material is indicated by high average self potential along the southwest flank of the Elk Hills structure and by especially high average values at the southwest corner of NPR -1 , where the Olig sand zone is present. This relation suggests that the primary source of sediment supply was from the south or southwest. Low self potentials probably indicate much clayey material along the northeast side of the field. The pattern can be explained if irregularities were produced on the sea floor by growing-anticlinal structures. The strength of currents carrying sediment from regions to the south or southwest would be decreased in the lee of the raising folds, which would allow the finer sediment to accumulate there. Winnowing of clays would occur in shoal areas toward the sediment source.

Only a few fragments of megafossils have been re- 
ported from the cores and samples of the Tupman Shale Member. In cores from well 324-19R, R. S. Beck (written commun., 1970) found fragments of mollusks, and Berryman (1973, p. D15) observed a few pelecypod fragments and pelecypod molds. The unit operator reported crab claws and molds of Yoldia and Macoma near the base, casts of Macoma and Arca near the middle, and Pecten terminus near the top. The paucity of megafossils contrasts sharply with the large megafossil population of the overlying Carman.

Foraminifers are common to abundant in all but the middle part of the Tupman. Buliminella elegantissima is the most abundant, followed by Bucella frigida (Eponides exigua). The range of both species extends through the Etchegoin Formation and very likely into Miocene strata. Haplophragmoides sp. and Cassidinella (Virgulina) cf. C. subplana are present but less abundant; others are sparsely represented throughout the unit. Most specimens of foraminifers are leached and iron stained, which is characteristic of those found in early Pliocene beds at Elk Hills and vicinity, according to R. S. Beck (oral commun., 1970). Some specimens in the lower part of the Tupman are silicified. Sponge spicules, radiolarians, diatoms, fish remains, and ostracodes are scattered through the section.

\section{OLIG SAND ZONE}

The Olig sand zone is present at the base of the Tupman Shale Member in the western part of the Elk Hills field. In well 354-26Z (pl. 13) in the Asphalto oil field, the Olig sand zone is more than 800 feet thick and consists of three lower sandstones, 20-75 feet thick, and an upper sandstone, more than 500 feet thick, separated by beds of siltstone and shale, 30-75 feet thick. The upper, thick sandstone thins rapidly northeastward and wedges out near the east limit of the Asphalto field. Two of the lower, thin sandstones continue northeastward into the western part of the Elk Hills field. In the McKittrick area, the Olig sand has been considered conformable with and a part of the Reef Ridge Shale by Zulberti (1956, p. 52); he regarded the top of the sandstone to be an erosional surface overlapped westward by the Etchegoin and San Joaquin Formations. Church, Krammes, and others (1957) showed the Olig sand in the lower Etchegoin resting unconformably on the Reef Ridge Shale. Foss and Blaisdell (1968, p. 37) and Foss (1972, p. 45) included the Olig sand as a regressive sand in the Reef Ridge and reported that the sandstone becomes increasingly coarse toward the top. Berryman (1973, p. D13) included the stratigraphic equivalent of the Olig sand, a thin pebbly shale in well 324-19R (Elk Hills) and thin conglomerates in nearby wells, in the Etchegoin Formation. Adkison (1973, p. 42-43) also placed a 67-foot-thick Olig sand in well 526-30R (Elk Hills) in the Etchegoin. The sandstone in well 526-30R ranges from very fine grained sandstone at the top to very coarse grained sandstone containing some granules of quartz and feldspar at the base. Two additional thin beds of very fine to fine grained sandstone are present below the thicker bed in well 526-30R and are included in the Olig sand zone in this report. The correlation of individual sandstones in the Olig sand zone is best illustrated on plate 13 .

The thickness of the Olig sand zone, as shown in figure 37 , ranges from more than 900 feet at the southwest edge of the Asphalto field to 0 feet where it pinches out northeast of Asphalto and across the west end of the Elk Hills field. It appears to be a regressive sand laid down during uplift of the Temblor Range to the southwest and west and shallowing of the seas as the shoreline retreated basinward.

BULIMINELLA SILT ZONE

The Buliminella silt zone makes up the whole Tupman Shale Member in all but the westernmost part of the Elk Hills oil field. Its thickness along line AF (pls. $8-12$ ) across the field ranges from about 700 feet in the western part to more than $1 ; 450$ feet in the eastern part. The lithology is a monotonous succession of olive-gray silty shale beds broken only by a group of three limy silty sandstone beds near the middle, some scattered siltstone beds, and a few siderite layers. The limy silty sandstone beds near the middle are 3-15 feet thick in most wells. As much as 40 percent of the sandstone consists of fine-grained phosphate pellets. The top of the upper sandstone, known as the 0 horizon by the unit operator, can be readily traced throughout the Elk Hills field and vicinity. The foraminifer Buliminella elegantissima is so abundant in the entire unit that the name "Buliminella silt" has been applied to it by petroleum geologists for many years.

\section{CARMAN SANDSTONE MEMBER}

The Carman Sandstone Member was named for the old Standard Oil Hay-Carman camp in sec. 36R, not the "Hay-Carman lease in sec. 36" (Berryman, 1973, p. D12). Berryman (1973, p. D15-D23) described the unit from continuous cores taken between depths of 2,095 and 3,387 feet in well 324-19R (pl. 14). The 1,292-foot sequence of Carman in that well consists mostly of interbedded greenish-gray siltstone and greenish-gray partly feldspathic and glauconitic very fine to medium-grained sandstone. Beds of soft greenish-gray shale are scattered through the sequence but are more common in the upper part. Some of the siltstone and sandstone beds, particularly in the lower part, contain phosphate pellets. The base of the Carman is drawn at the base of a fossiliferous siltstone and sandstone sequence overlying the relatively unfossiliferous shale in the Tupman Shale Member. This contact can be readily 


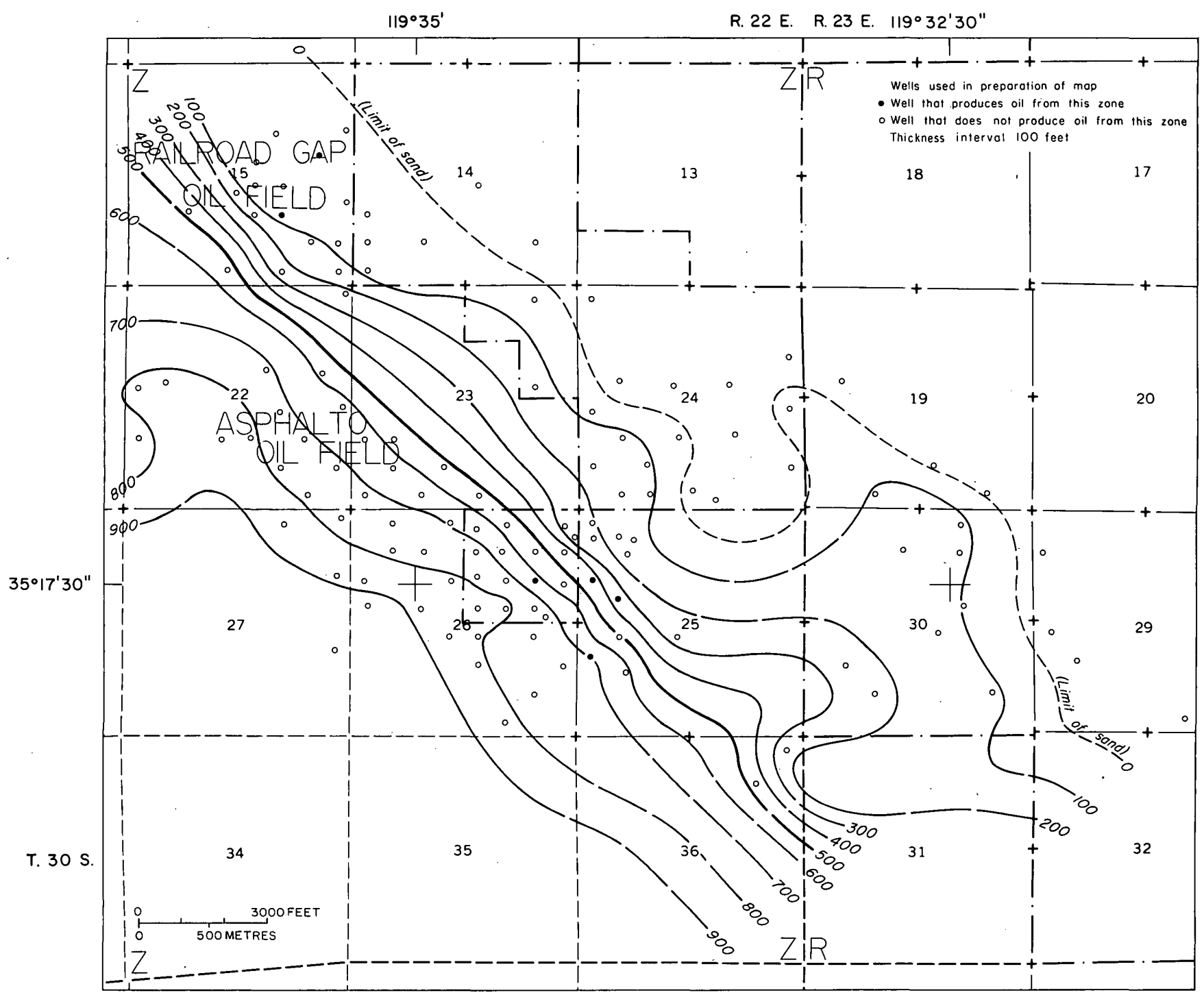

FIGURE 37.-Thickness of Olig sand zone in the Railroad Gap, Asphalto, and western part of the Elk Hills oil fields.

identified on most electric logs by the relatively abrupt decrease downward in the value of both the selfpotential and resistivity curves at the top of the shale in the Tupman. A thin interval of sandstone, bearing Pseudocardium (Mulinia), marks the top of the Carman Sandstone Member and the Etchegoin Formation. It coincides approximately with the upper limit of Buccella frigida [Eponides exigua], which, according to R. S. Beck (oral commun., 1970), marks the top of the Etchegoin Formation at Elk Hills and vicinity. This interval, informally known as the "Mulinia zone," has been correlated by Woodring, Roundy, and Farnsworth (1932, p. 39) and Barbat and Galloway (1934, p. 482) with the upper Mulinia zone at Kettleman Hills. The Mulinia zone has been used as a stratigraphic marker for many years in the oil fields of the southern San Joaquin Valley. The sandstones within the zone are important oil reservoirs at Elk Hills and the term Mulinia sand zone is used in this report.

The thickness of the Carman Sandstone Member along line AF (pls. 8-12) ranges from about 900 feet in Railroad Gap (pl. 8) to about 2,000 feet in easternmost Elk Hills (pl. 12). The member is thin on the broad tops of the Western and Eastern anticlines, although the areas where the member is thinnest are offset about a quarter of a mile to the southwest of the structural axes of the anticlines. The member is also thin beneath the North and South Coles Levee fields but not over the Flickinger anticline (sec. 25Z). The rate of thickening from the anticlinal axes northeastward is about 700800 feet per mile and is about the same or slightly greater from the axes southwestward.

The relative self-potential patterns on plate 21 suggest that, on the average, the best sorted and proba- 
bly the coarsest clastic material was deposited along the southwest flank of the growing anticlines, in the structurally lower area between the two anticlines, and in a broad area nearly flat structurally across the North Coles Levee field. The irregular distribution patterns do not indicate much, if any, winnowing of the bottom sediments on the crests of the anticlines. The high self potentials along the southwest flanks of the anticlines suggest source areas for sediment to the south and west, and the self potentials in the structurally lower area between the anticlines may be related to strong bottom currents around positive bathymetric anomalies created by the structural growth. The self potentials in the broad structural flat across the North Coles Levee field may represent a delta front of the ancient Kern River that carried sediment from the Sierra Nevada. If so, two source areas are apparent for sediment at Elk Hills in Carman time in contrast to a single source area in earlier Pliocene time.

The Carman seems to be a complex of delta-front siltstone and fine-grained sandstone deposited in four cycles, each of which includes shallow-water deposits at the base grading upward to brackish-water deposits and, in the last cycle, fresh water deposits at the top. The highest occurrence of glauconite in well 324-19R (Berryman, 1973, p. D22) is found at the Bittium horizon (pls. 8-12) in the lower part of the uppermost cycle of the Carman sequence, the Mulinia sand zone. The presence of glauconite is generally considered to indicate a deep- to shallow-marine depositional environment (Heckel, 1972, fig. 2). The lowest occurrence of fossils definitely of freshwater origin in the same well is reported to be in the upper 50 feet of the Mulinia sand zone. Carbonized plant fragments are common in the Calitroleum, Wilhelm, and Mulinia sand zones in well 324-19R but were not reported in the Gusher sand zone. It seems likely that the Carman was deposited at depths ranging from about 200 feet to only a few feet.

The sandstones in the Carman are included in the Shallow Oil Zone of the Elk Hills Engineering Committee (1957a). They are grouped, in ascending order, into the Calitroleum, Gusher, Wilhelm, and Mulinia sand zones. Except for the Mulinia zone added in these studies (Berryman, 1973, p. D16, D17), the zone names (pl. 17) are derived from "group" names of engineering reports of the Elk Hills Engineering Committee (1957a, fig. 1), which, in turn, were probably derived from the Midway-Sunset oil field, about 10 miles south of Elk Hills (Woodring and others, 1932, p. 48, fig. 4; Woodward, 1945). The four sand zones of the Carman are shown on plates 8-16 and briefly will be described.

$$
\text { CalitTroleum SAND ZONE }
$$

The Calitroleum sand zone was described from cores between depths of 3,114 and 3,387 feet in well 324-19R (Berryman, 1973, p. D19-D20). The lower one-third is mostly light-olive-gray silty shale and sandy siltstone. Phosphate pellets, coarse angular quartz grains, and very coarse subangular feldspar grains are present in many of the siltstone beds. Thin layers of carbonate rock are scattered through the silty shale; the shale exhibits filled borings and disturbed laminations. The upper two-thirds of the zone is chiefly light-olive-gray siltstone and lesser amounts of light-olive-gray very fine grained silty and clayey sandstone. Most cores of the siltstone are friable.

Pelecypods, marine gastropods, and foraminifers are fairly abundant in the Calitroleum sand zone. Two gastropods, Mitrella sp. and Odostomia sp., and the barnacle Balanus sp. were reported (Berryman, 1973, p. D18-D20). The most common species of foraminifers, according to R. S. Beck (written commun., 1970), include Buliminella elegantissima, Elphidiella [Elphidium] hannai, Elphidium hughesi, Buccella frigida [Eponides exigua], Eponides cf. E. blancoensis, Florilus [Nonionella] cushmani, and Quinqueloculina sp.

Along line AF (pls. 8-12), the Calitroleum ranges in thickness from 185 feet in well 324-29R to 535 feet in well 374-27R. The upper limit of the Calitroleum sand zone is drawn at a lithologic change upward from predominantly siltstone to predominantly silty shale and clayey siltstone. This horizon can be traced by the electric-log characteristics across the Elk Hills field. Two oil-bearing sandstones, one at the top and the other at the base of the zone (pl. 17), have been termed the "First Calitroleum sand" and "Second Calitroleum sand," in downward order, by the Elk Hills Engineering Committee (1957a, fig. 1). As shown on the sections along line AF (pls. 8-12), these sands are lenticular and are very thin or absent in most wells.

The thickness distribution of the Calitroleum sand zone is shown on plate 22. The Calitroleum sand zone is less than 300 feet thick on the tops of the Eastern and Western anticlines and more than 600 feet thick on the flanks and in the North and South Coles Levee fields. The structure, as drawn on the Reef Ridge Shale (pl. 4), is closely reflected by the thickness distribution. This suggests continued growth of the anticlines during deposition of the Calitroleum sand zone.

$$
\text { Gusher SAND zone }
$$

The Gusher sand zone in well 324-19R (pl. 14) is 534 feet thick and is composed chiefly of interbedded coarse-grained siltstone and fine- to medium-grained sandstone, and lesser amounts of shale. Berryman (1973, p. D20) described the siltstones as light olive gray, slightly micaceous, very finely sandy, and mostly friable and the sandstones, which are mainly in the 
middle and upper parts of the zone, as light olive gray, moderately well sorted, and mostly friable. The siltstones are composed mostly of coarse silt, and the sandstones of fine to medium clear subangular quartz and light-gray subrounded feldspar grains. Glauconite grains occur in the thin very fine grained sandstone laminae within the siltstone sequences and commonly scattered throughout the sandstone beds. In some sandstone beds, the glauconite is concentrated in layers in which it amounts to as much as 15 percent of the rock. Phosphate is present as pellets, nodules, and fossil fragments in some beds of siltstone and sandstone.

Pelecypods and gastropods are common in the Gusher sand zone. Pecten oweni is the most common pelecypod. The pelecypods Tellina(?) sp. and Transenella sp. and the gastropod Branillus(?) were found only in the Gusher sand zone in well 324-19R. Foraminifers are common in most of the zone. The species include $E l$ phidiella [Elphidium] hannai, Buccella frigida [Eponides exigua], Elphidium hughesi, and Buliminella elegantissima. Florius [Nonionella] cushmani is sparsely present in the zone and does not range above it in well 324-19R.

The thickness of the Gusher sand zone along line AF (pls. 8-12) ranges from less than 400 feet on the west to almost 1,000 feet on the east but does not increase uniformly. The top of the zone is placed at the top of a series of sandstone and siltstone beds that is most prominent at the east end of the Elk Hills field (pl. 12), but the top can be recognized easily in most other wells by a deep inflection of the self-potential curve and other characteristics on electric logs. In most wells a thick shale interval overlies the uppermost series of sandstones and siltstones.

Four sandstone reservoirs of oil within the Gusher sand zone have been identified in some wells by the Elk Hills Engineering Committee (1957a, fig. 1), in downward order, as the First, Second, Third, and Fourth Gusher sands (pl. 17). These sandstones cannot be traced individually across Elk Hills field because they tend to merge in some areas and to wedge out in others. They seem to be thickest over the Western anticline, in the eastern part of the Elk Hills field, and in the North Coles Levee field.

The thickness distribution of the Gusher sand zone is shown on plate 22. The Gusher sand zone is less than 500 feet thick on the top of the Western anticline and less than 400 feet thick on the Eastern one. Thicknesses of about 800 feet have been penetrated on the flanks of these anticlines and of more than 1,000 feet near the North Coles Levee field. The thickness distribution conforms closely to the underlying structure (pl. 4), which suggests that the anticlines continued to grow while the Gusher sand zone was deposited.

\section{WILHELM SAND ZONE}

The Wilhelm sand zone in the Pliocene reference section at Elk Hills (Berryman, 1973, p. D21, D22) consists of 305 feet of friable greenish-gray to light-olive-gray clayey biotitic very sandy siltstone interbedded with greenish-gray silty shale and greenish-gray partly glauconitic feldspathic silty sandstone. About one-third of the zone in well $324-19 \mathrm{R}$ ( $\mathrm{pl}$. 14) is made up of sandstone beds less than 15 feet thick. The more abundant fossils are marine mollusks and foraminifers. The foraminifers include Buccella frigida [Eponides exigua], Buliminella elegantissima, Elphidiella [Elphidium] hannai, Elphidium hughesi, and Quinqueloculina sp. (R. S. Beck, written commun., 1970).

The Wilhelm sand zone is about 200 feet thick at the west end (Railroad Gap) of line AF (pls. 8-12) and about 300 feet thick at the east end (North Coles Levee). A distinct lithologic change upward from sandstone and siltstone to shale marks the contact between the Wilhelm sand zone and the overlying Mulinia sand zone. This change is well reflected on the electric logs by a sharp decrease in both the self-potential and resistivity values. This contact is one of the most consistent and easily correlated horizons within the Pliocene rocks at Elk Hills, and it can be traced readily from Railroad Gap to North Coles Levee.

Within the Wilhelm sand zone, four lenticular sandstones that contain oil in some wells have been named, in downward order, the First, Second, Third, and Fourth Wilhelm sands (pl. 17) by the Elk Hills Engineering Committee (1957a, fig. 1). These sandstones cannot be traced individually across Elk Hills field with assurance. They are thick and easily differentiated in the area of the Western anticline and in the vicinity of the North Coles Levee field.

The thickness distribution of the Wilhelm sand zone is shown on plate 23. The minimum thickness on the top of the Western anticline is about 300 feet; on the Eastern anticline it is less than 200 feet. Thicknesses in excess of 450 feet are present on the flanks and in the syncline between the two anticlines. The thickness distribution is closely related to the underlying structure (pl. 4), which indicates continued structural growth during Wilhelm deposition.

\section{Mulinia SAND ZONE}

The Mulinia sand zone, the uppermost zone in the Carman Sandstone Member, is 180 feet thick and consists mostly of soft greenish-gray shale, siltstone, and sandstone in the reference section (well 324-19R, pl. 14). Sandstone and siltstone beds are more common in the upper part than in the lower. Three fairly persistent sandstone bodies in the zone are referred to by the Elk 
Hills Engineering Committee (1957a, fig. 1), in upward order, as the Bittium sand, Sub-mulinia sand, and the Mulinia sand (pl. 17). Not all sandstones are present in each well, and the lenticularity of the sands causes uncertainty in their correlation across Elk Hills field. Because of this the names are not used on the sections in this report even though they are valid and useful in many parts of the field. The sandstones are mostly greenish gray, well sorted, and very fine to medium grained. A gastropod-fossil layer, the Bittium horizon, commonly occurs at or near the top of the Bittium sand, 50-100 feet above the base of the Mulinia sand zone in most wells. This fossil horizon has been translated into an electric-log marker through oil-field usage over the years and is shown as such in many wells along line AF (pls. 8-12). Berryman (1973, p. D22) noted that the Bittium sand marked the highest stratigraphic occurrence of glauconite in well 324-19R. He also recorded a 6 -inch bed of conglomeratic shale containing sand grains, carbonaceous plant fragments, and rounded dolomite or phosphate pebbles as large as 1 inch in diameter between the Bittium and Sub-mulinia sands.

Pelecypods, gastropods, and foraminifers are abundant in the Mulinia sand zone. The pelecypod Pseudocardium (Mulinia) is diagnostic of the zone and common only in the upper part. The freshwater gastropod Fluminicola is found with Pseudocardium (Mulinia) and marks the lowest stratigraphic occurrence of freshwater fossils in well 324-19R. According. to R. S. Beck (written commun., 1970), the foraminifers present are Elphidium hughesi, Buccella frigida [Eponides exigua], Buliminella elegantissima, Elphidiella [Elphidium] hannai, and Quinqueloculina(?) sp. Of these only Buliminella elegantissima and Buccella frigida [Eponides exigua] range above the Mulinia sand zone in well 324-19R.

In the western part of the Elk Hills field, the contact of the Mulinia sand zone and the overlying Scalez sand zone in the San Joaquin Formation is marked by the fossil Pseudocardium [Mulinia] and its equivalent electric-log characteristic. In the central part, the Mulinia sand is present at the top of the zone in many wells. In the eastern part, the Mulinia sand is less distinct or absent, but the contact can be traced at the base of the thick sandstone sequence in the overlying Scalez sand zone.

The thickness of the Mulinia sand zone ranges from about 150 feet to almost 400 feet along line AF (pls. $8-12$ ). The Mulinia sand zone is more than 400 feet thick on the flanks of the Elk Hills structure but as thin as 175 feet on the crest of the Western anticline (pl. 23). It is about 250 feet thick on the top of the Eastern anticline. The thickness distribution conforms fairly well to the underlying structure (pl. 4).
SAN JOAQUIN FORMATION

Usage of the name San Joaquin Formation in this report follows that of Berryman (1973). (See discussion "Rocks of Pliocene Age.") The San Joaquin Formation consists mostly of shale and interbedded clayey siltstone and silty sandstone. The sandstone is scattered through the interval and is thin, very fine to fine grained, and silty. The shale is olive to greenish gray and has a smooth texture and a slightly waxy luster. The upper contact of the formation with the Tulare Formation is marked in most places by a pronounced lithologic change upward from shale to poorly sorted feldspathic sandstone and conglomerate. In some places the lower beds of sandstone and conglomerate of the Tulare interfinger with the San Joaquin beds. As indicated on section EF (pl. 12), the top of the San Joaquin Formation is stratigraphically higher in the Elk Hills field than in the North Coles Levee field.

Along the line of the cross sections, the thickness of the San Joaquin Formation ranges from about 1,200 feet in Railroad Gap (pl. 8) to nearly 2,100 feet in the eastern Elk Hills (pl. 12). The thickness distribution of the San Joaquin Formation (pl. 24) reflects fairly well the structure of the formation in the Elk Hills field. Elongate areas where the formation is thin are present along the crest of the Western anticline. They form linear belts along the crest not duplicated on the Eastern anticline. There, isolated areas where the formation is thin are scattered along the crest of the anticline, partly down the southwest flank, and far out on the eastern nose. Thinning may have been caused by movement along the numerous intersecting faults on the Eastern anticline. The thickness patterns of the San Joaquin in the Railroad Gap and North Coles Levee fields also are related, although less clearly, to the structure of the formation. The thin area in the Railroad Gap field seems to be offset westward from the highest part of the structure. An area of thin rocks in the North Coles Levee field is present where a long structural nose extends into the field. The uplifted block between two long northeast trending normal faults is shown by an area of thin rocks in secs. 1G, 2G, and 3G on plate 24 .

Some inferences about the environment during deposition of the San Joaquin Formation can be drawn from the relative self-potential patterns shown on plate 24 . The higher self-potential values, which presumably reflect higher porosity and larger average grain size of the sediments, are present in the eastern Elk Hills and North Coles Levee areas. They suggest continued shoaling in this area, perhaps related to the influx of coarser sediments from the Sierra Nevada and the development of the ancient Kern River delta. Sediments from the Temblor Range to the west and south were finer than the sediments from the east. According to Berryman 
(1973, p. D24-D28), the San Joaquin Formation was deposited in an environment of alternating brackish water and fresh water.

The formation consists of two lithologic zones, a lower or Scalez sand zone about 150-500 feet thick and an upper or Mya sand zone about 700-1,700 feet thick. These zones were used in unpublished studies of electric-log correlations by J. C. Maher, R. J. Lantz, and R. D. Carter (unpub. data, 1970); the lithology was described from cores of well 324-19R by Berryman (1973, p. D25-D28).

\section{SCALEZ SAND ZONE}

The Scalez sand zone comprises the sandstone and shale beds between the Mulinia fossil horizon and the basal Mya sand, or their electric-log equivalents (pl. 17). The name refers to the presence of the operculum of the gastropod Scalez petrolia in this zone. Hanna and Gaylord (1924, p. 147-149) discovered the fossil in 1921 in wells in the eastern Elk Hills field. A thin bed of brittle brown shale in which the fossil occurs can be traced throughout the field by its electric-log characteristics and, as a result, has become known as the Scalez marker bed whether or not the fossil is known to be present. The top of this bed is shown as the Scalez horizon on sections in this report. Four different beds that contain Scalez have been found in this zone in wells in the western San Joaquin Valley; the lowermost of these is the marker bed at Elk Hills according to Woodring, Roundy, and Farnsworth (1932, p. 36-38). Only a single specimen of Scalez has been found in outcrops of the San Joaquin Formation, and that one was found about 50 miles north of Elk Hills near the base of the formation in Kettleman Hills (Woodring and others, 1940 , p. 40$)$

Berryman (1973, p. D25) described the Scalez sand zone in the reference section (well 324-19R, pl. 14) as a 181-foot-thick sequence composed mostly of greenishgray to light-olive-gray clayey shale having a smooth texture, slightly waxy luster, and a blocky to hackly. fracture. He noted a few beds of siltstone as much as 10 feet thick in the upper half and a thin bed of yellowishbrown dolomite near the middle but no sandstone beds whatever in the unit. This composition is fairly typical for the zone in the western part of Elk Hills. On the northeast flank of the Eastern anticline and in the North Coles Levee field, a northward-thickening wedge of many lenticular sandstone beds interbedded with shale occupies much of the lower half of the zone (pls. 11, 12). The fossil Scalez was reported by the unit operator to be present in the middle of a brown shale bed, 5 feet thick and 10 feet above the base of the zone in well 324-19R. Berryman (1973, p. D25) was unable to find any specimens of Scalez in this interval and suggested that the fossils probably had been removed from the well samples prior to his study. He did find cores of a 1-foot-thick coquina, locally called Amnicolite, about 20 feet above the base. The rock consists mostly of minute freshwater gastropods of the genus Amnicola and some black ostracodes. The "Amnicolite bed" is present at approximately the same stratigraphic horizon in eastern Elk Hills (Roberts, 1927, p. 6-7) and in Kettleman Hills, many miles to the north (Barbat and Galloway, 1934 , p. 479). R. S. Beck (written commun., 1970) identified the foraminifers Ammonia beccari [Discorbis (Eponides) sp.] and Elphidium hughesi in cores of well 324-19R. These are generally indicative of a brackishwater environment. Plant fragments were found in the upper half of the zone.

As shown on plate 17, the Scalez sand zone includes as many as four important oil-bearing sandstones in some parts of the Elk Hills field. The Elk Hills Engineering Committee has termed these, in upward order, the Second Sub-Scalez sand, the First Sub-Scalez sand, the Above Scalez sand, and the "E"-laminated sand.

In most wells in the central and eastern parts of the Elk Hills field and in the North Coles Levee field, the top of the Scalez sand zone is drawn at the base of a thick sandstone, locally known as the "Fourth Mya sand," that yields dry gas in some wells. In a few wells (for example, 326-34S, pl. 11), a lower sandstone lens known as the "Fifth Mya sand" is present below the "Fourth Mya sand;" its base marks the top of the Scalez sand zone in those wells. Thin siltstone equivalents of the Mya sandstones (pl. 11) extend westward toward the Railroad Gap field; these beds are not distinctive enough for accurate correlation. Identification of the Scalez sand zone in western Elk Hills depends mostly on recognition of the underlying and overlying succession of beds as shown in detail by electric-log patterns.

The thickness of the Scalez sand zone along line AF (pls. 8-12) ranges from about 150 feet in the western Elk Hills field (pl. 8) to more than 450 feet in the eastern part (pl. 12), where thick sandstones are well developed in the lower half. The Scalez sand zone ranges in thickness from about 150 feet on the higher parts of the Elk Hills structure to more than 500 feet on the flanks (pl. 25). The thickness distribution does not reflect, except in the most general way, the structure of the Eastern anticline. Here thin and thick areas are unsystematically scattered on the higher part of the anticline.

MYA SAND ZONE

The Mya sand zone, which makes up about 80 percent of the San Joaquin Formation, is named for the abundance of the pelecypod $M y a$ in the zone. The zone consists mostly of shale and siltstone but contains several intervals of interbedded sandstone and siltstone. Much 
of the shale is soft, smooth, greenish gray to light olive gray, and slightly waxy. The siltstones and sandstones are generally carbonaceous, well sorted, and very friable. The sandstones are mostly very fine to fine grained, silty, clayey, slightly micaceous, and poorly cemented. As many as five sandstone beds are thick enough to have been identified separately and numbered in downward order-Mya sands 1 to 5 . Because they are extremely lenticular, these sandstones cannot be correlated from well to well with certainty, and the names are not used in this report.

The principal megafossils in the Mya sand zone are the marine pelecypods $M y a$ and Ostrea lurida and the nonmarine pelecypods Anodonta sp. and Valvata humerosa. Plant fragments are found throughout the zone. According to R. S. Beck (written commun., 1970) the common foraminifers in the zone include Ammonia beccari [Discorbis (Eponides) sp.], Elphidiella [Elphidum] hannai, and Eponides cf. E. blancoensis. Ostracodes are present mainly in the lower half. Fish remains are also present. The fossils indicate an alternating brackish- and fresh-water environment of deposition.

The upper limit of the Mya sand zone is placed at the base of a 600-2,150-foot-thick succession of sandstone and conglomerate beds in the Tulare Formation. The upper beds of the Mya zone marking the top of the San Joaquin Formation interfinger with the lower Tulare beds as indicated on section EF (pl. 12). The highest occurrence of $M y a$ generally is found 50-150 feet below the base of the sandstone conglomerate sequence. At the type locality of the San Joaquin Formation at Kettleman Hills, Barbat and Galloway (1934, p. 480) placed the upper contact at the base of a massive sand, 152 feet above the "uppermost 'Mya zone'." However, Woodring, Stewart, and Richards (1940, p. 13-15, 28-32) used the highest occurrence of $M y a$ as the contact at Kettleman Hills.

The thickness of the Mya sand zone along line AF (pls. 8-12) ranges from about 1,000 feet in the Railroad Gap field to about 1,700 feet near the North Coles Levee field. The thickness distribution of the Mya sand zone is shown on plate 25. Thicknesses of less than 800 feet are present along the west side of the Asphalto field. Thicknesses of 800-1,000 feet mark the higher parts of the structure; thicknesses in excess of 2,000 feet have been drilled on the south flank of the Elk Hills structure.

\section{ROCKS OF PLIOCENE AND PLEISTOCENE AGE}

\section{TULARE FORMATION}

F. M. Anderson (1905, p. 181-182) applied the name Tulare Formation to a thick succession of nonmarine poorly consolidated sandstone, conglomerate, and claystone beds exposed at intervals along the west border of the San Joaquin Valley. The name was derived from Tulare Lake (fig. 34), the shore of which at that time lay close to North Dome of Kettleman Hills, where the beds are well exposed. Anderson noted that the Tulare Formation is at least 1,000 feet thick there and lies conformably on the "San Joaquin Clays." Although a type locality was not designated by Anderson, subsequent writers beginning with Arnold and Anderson (1910, p. 143) have regarded Kettleman Hills as the type region.

Beds equivalent to the Tulare Formation at Kettleman Hills were mapped in Elk Hills and vicinity by Arnold and Johnson (1910, p. 74-90) as the upper part of the "McKittrick Formation" but were later separated and identified as the Tulare in the McKittrick area (fig. 34) by Gester (1917, p. 210-216). Pack (1920, p. 43-51) mapped the same beds in the southwest San Joaquin Valley as the "Paso Robles ('Tulare')" following the usage of English (1918). Hoots (1930, p. 288) reinstated the name Tulare Formation in the southern San Joaquin Valley. Exposures of the Tulare in its type region at Kettleman Hills were mapped and described in detail for the first time by Woodring, Stewart, and Richards (1940, p. 13-14), who suggested a type section on the northeast side of North Dome.

The beds at Kettleman Hills later termed Tulare were thought to be Pliocene in age by Watts (1894, p. 55) on the basis of their freshwater molluscan fossils and their conformity with underlying beds of known Pliocene age. Woodring, Stewart, and Richards (1940, p. 103-104) examined evidence of age in detail and concluded that the Tulare Formation should be regarded as late Pliocene and Pleistocene(?) in age. In an earlier report on Elk Hills, Woodring, Roundy, and Farnsworth (1932, p. 27) observed that the Tulare, in the type region at least, probably "is of late Pliocene age or straddles the Pliocene-Pleistocene boundary." Foss and Blaisdell (1968, p. 35) assigned the Tulare Formation to the Pleistocene Series on the basis of stratigraphic position and molluscan fauna. Croft (1969, p. 16) stated that the upper part of the Tulare is Pleistocene in age according to both faunal evidence and potassium-argon dating. The U.S. Geological Survey classification of this formation as late Pliocene and Pleistocene in age is followed in this report.

Interbedded nonmarine mudstones and pebbly sands of the Tulare Formation (fig. 38) blanket Elk Hills and vicinity to depths of $600-2,150$ feet. Approximately $700-850$ feet of these beds are exposed in the deeply incised gullies coursing off the flanks of the Elk Hills anticlinal structure. These exposed beds have been mapped and described in detail by Woodring, Roundy, and Farnsworth (1932, p. 16-27, pl. 1), who divided 


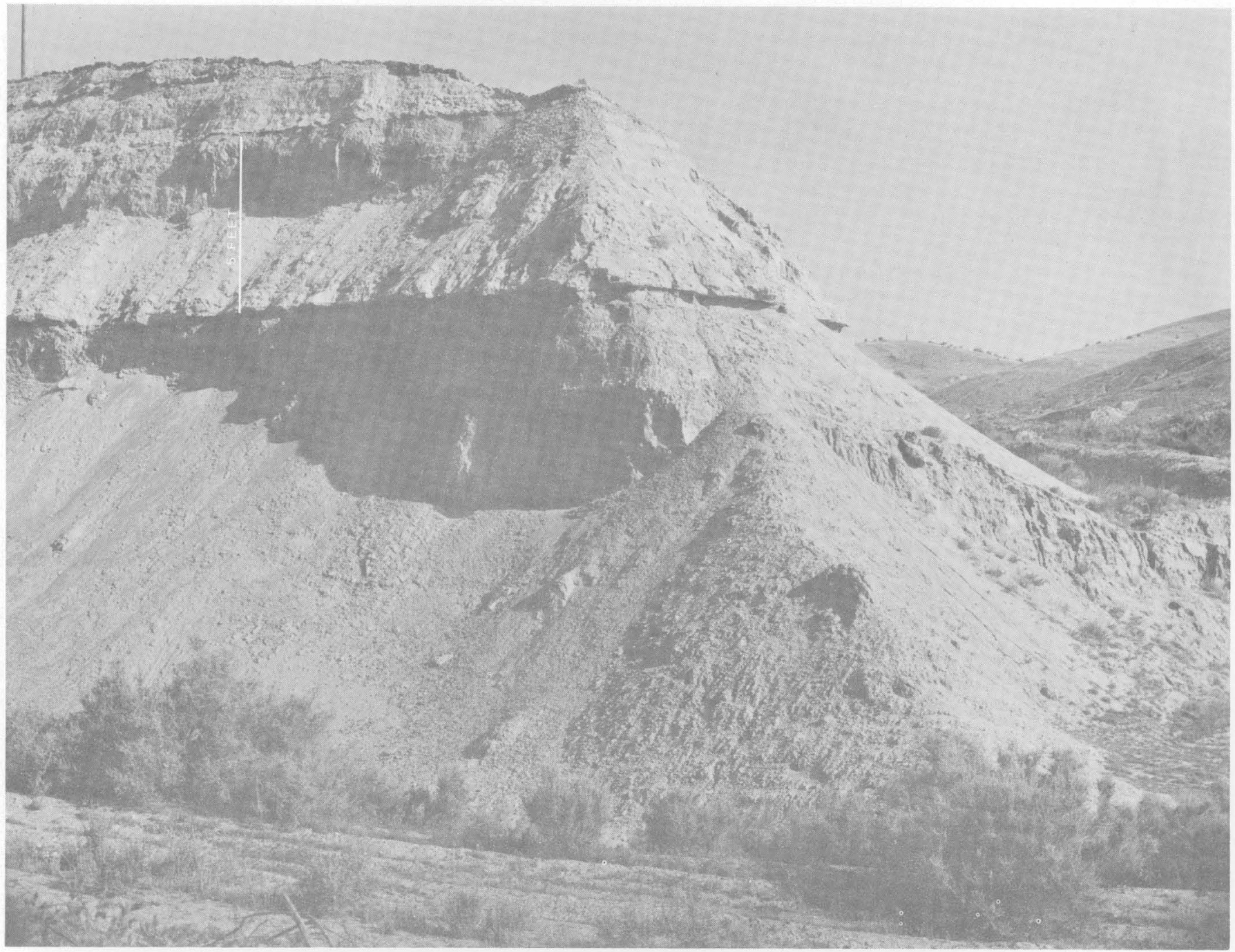

Figure 38.-Tulare Formation in eastern Elk Hills.

them into lower and upper parts on the basis of the color of the mudstones,

The lower part of the exposed beds consists of alternating beds of olive-gray gypsiferous mudstone and cross-bedded gray feldspathic sandstone with pockets and irregular stringers of conglomerate. A dirty-white partly silicified limestone less than 3 feet thick is present about 30 feet below the top of the lower part in places. Woodring, Roundy, and Farnsworth (1932, pl. 1) mapped this bed as limestone B along much of the north flank of the Elk Hills structure. The upper part of the exposed sequence, as much as 465 feet thick on the southeast flank, is lithologically similar to the lower part except that the mudstones are a uniform light-buff color and the sandstones near the top contain a great variety of large pebbles of siliceous shale, chert, quartz, sandstone, and igneous rock. The lowest buff mudstone, the base of the upper part, is continuous over the eastern third of Elk Hills. The next buff mudstone above the basal one has an irregular dirty-white feldspathic sandy limestone at its top in much of its exposure. This limestone, which lies about 50-80 feet above "limestone B," was designated "limestone A" and used as a structural datum on the geologic map by Woodring, Roundy, and Farnsworth (1932, pl. 1). It contains remains of Chara, a lime-secreting quiet-water algae common in ponds, lakes, and brackish-water lagoons.

According to Woodring, Roundy, and Farnsworth (1932, p. 25-26), no invertebrate fossils have been found in outcrops at Elk Hills, but some vertebrate fossils, Chara, and silicified wood have been found. The vertebrates include remains of a camel (Procamelus?), a rabbit (Lepus), a wood rat (Neotoma), a cotton rat (Sigmodon), and some horse teeth. These were found in the buff mudstone at the base of the upper part of the exposed beds and in limestone A.

The following section measured by Woodring, Roundy, and Farnsworth (1932, p. 24) along the steep 
slope on the east side of the ridge in the northwestern part of sec. 23, T. 30 S., R. 23 E., shows the lithology of beds at the base of the upper part of the Tulare Formation and at the top of the lower part, including limestone B. Section of part of Tulare Formation in sec. 23, T. 30 S., R. 23 E.

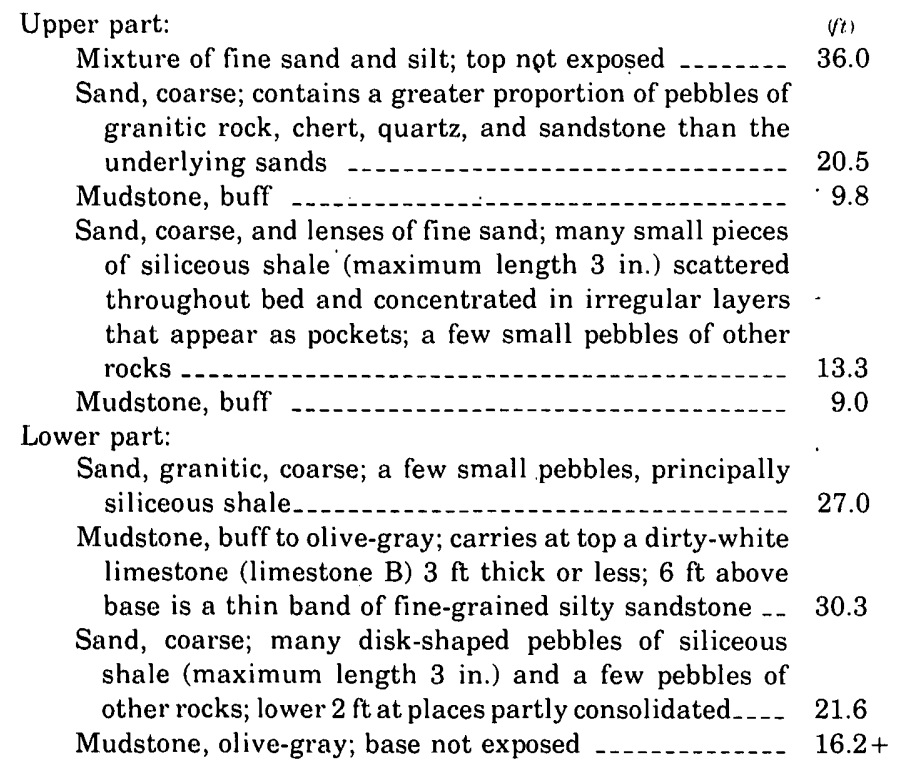

Sand, granitic, coarse; a few small pebbles, principally siliceous shale...................................

Mudstone, buff to olive-gray; carries at top a dirty-white limestone (limestone B) $3 \mathrm{ft}$ thick or less; $6 \mathrm{ft}$ above base is a thin band of fine-grained silty sandstone _. 30.3

Sand, coarse; many disk-shaped pebbles of siliceous shale (maximum length $3 \mathrm{in}$.) and a few pebbles of other rocks; lower $2 \mathrm{ft}$ at places partly consolidated....

Mudstone, olive-gray; base not exposed 21.6

The Tulare Formation in many wells at Elk Hills and vicinity can be divided into a lower sandstone and conglomerate member, an overlying claystone member, and an upper sandstone and conglomerate member (pls. 8-11, 13, 15). These members are recognizable on electric logs in the Railroad Gap and Asphalto oil fields as well as in the western two-thirds of the Elk Hills field. In the eastern part of the Elk Hills field and in the North Coles Levee field, the claystone member loses its identity and the lower and upper sandstone and conglomerate members cannot be separated consistently (pls. 12, 16). The base of the Tulare probably represents a facies change from predominantly siltstone and shale, assigned to the San Joaquin Formation, to coarser grained clastic rocks (pl. 12, wells CLA 21-32T and CLA 67-29T). The contact of the Tulare and the San Joaquin Formations is conformable in the Elk Hills and North Coles Levee fields, but it is unconformable to the west in the subsurface and in outcrops along the foothills of the Temblor Range, according to Church, Krammes, and others $(1957,1959)$.

Very few sets of drill cuttings from the shallow Tulare beds have been saved. One of the few wells for which Tulare samples are available is well $526-30 \mathrm{R}$ in the western part of the Elk Hills field. The Tulare is 1,280 feet thick in this well, and all but the upper 117 feet was sampled. The lithology was described in detail by Adkison $(1973$, p. 43-44; 47-51); the following summary is derived from his description.
The lower sandstone and conglomerate member, 567 feet thick, consists mostly of poorly consolidated lightolive-gray partly feldspathic pyritic and biotitic silty very fine to very coarse grained sandstone. Granules are scattered through some sandstone beds, and fragments of white chert are present in the poorly consolidated upper sands. The sandstone beds are as much as 50 feet thick and are separated by much thinner beds of siltstone and claystone.

The claystone member, 91 feet thick, consists mostly of light-olive-gray silty claystone, slightly dolomitic or calcareous in part. Some thin stringers of feldspathic very fine to very coarse grained sandstone separate the claystone beds in the upper part.

The upper sandstone and conglomerate member, 713 feet thick, is about 90-95 percent unconsolidated feldspathic medium to very coarse sand of which some beds contain granules and pebbles of feldspar, chert, limestone, quartzite, and granite and other igneous rocks. Siltstone and claystone beds, most of which are less than 5 feet thick, separate the thick sand bodies.

According to R. S. Beck (written commun., 1969) the lower sandstone and conglomerate member and the claystone member of the Tulare Formation in well 526-30R contain scattered fish remains, mollusk fragments, and reworked foraminifers. He reported also that ostracodes and thin-shelled pelecypods are present near the base of the lower sandstone and conglomerate member and that small gastropods, questionably identified as Amnicola, are present in the claystone member. Fossils were not found in the upper sandstone and conglomerate member of the Tulare Formation in well 526-30R.

The thickness of the Tulare Formation in wells in Elk Hills and vicinity ranges from 622 feet on the crest of the Eastern anticline to more than 2,000 feet along its south flank and along the nose that extends into the North Coles Levee field (pl. 24). The rate of thickening northward on the north flank of the Eastern anticline is approximately 700 feet per mile, and southward on the south flank it is about 900 feet per mile. The formation is notably thin in many isolated areas on the broad tops of the structures. The irregular distribution of these areas reflects uneven erosion of the exposed beds, especially in the eastern part of the field where erosion has thinned the formation on the upthrown sides of numerous normal faults. The effects of faulting are made more apparent by comparison of the thickness map (pl. 24) with the structure map of the Scalez horizon (pl. 4).

\section{QUATERNARY ALLUVIUM}

The Tulare Formation is covered by Quaternary alluvium along the perimeter of Elk Hills (Woodring and others, 1932 , pl. 1). The alluvium consists of poorly 
sorted sand, silt, clay, and pebbles and is virtually indistinguishable from the Tulare Formation. Small flat pebbles of white siliceous shale are especially abundant in the alluvium. Successively younger alluvial beds overlap older alluvial beds toward the hills. In Buena Vista Valley south of Elk Hills, Wood and Dale (1964, pl. 3) mapped deposits of interstratified sand, silt, clay, and gravel as the younger alluvium of the EdisonMaricopa area. These coarse clastic deposits interfinger eastward with silt and clay deposited in Buena Vista Lake. The thickness of the alluvium around Elk Hills is not known because of its lithologic similarity to the Tulare Formation, as shown by the log of the West Kern County Water District well, 4 miles east of Tupman. (See section "Ground Water.") The alluvium is Holocene in its upper part, but the lower part may be late Pleistocene (Wood and Dale, 1964, p. 42-43).

\section{DEPOSITIONAL SUMMARY}

Little detail can be offered on the depositional environment of Tertiary rocks at Elk Hills because of the lack of regional data. Only a few wells in the field have penetrated lower Miocene rocks, and none has reached basement. However, some idea of environmental conditions at Elk Hills during Tertiary time is available from published regional studies (Hoots and others, 1954; Repenning, 1960; Foss and Blaisdell, 1968; Bandy and Arnal, 1969; Barbat, 1971; Foss, 1972; Stanton and Dodd, 1972), from a study of Elk Hills cores (Berryman, 1973), and from thickness and relative self-potential maps of the upper part of the Miocene and the Pliocene rocks at Elk Hills (pls. 18-25).

The sea probably was deepest in the San Joaquin basin in late. Eocene time after the Coast Range orogeny. During this time the hard brown shale of the Kreyenhagen Formation, thousands of feet thick, was deposited across the deep sea floor. The Point of Rocks Sandstone Member accumulated as a thick wedge of sand within the shale sequence in a narrow trough adjacent and parallel to an uplift on the west. Foss (1972, p. 41, 43) suggested that this sandstone is a marine turbidite deposited in the bottom of a deep basin with oversteepened flanks.

The San Joaquin basin was occupied by a sea and received marine sediments continuously through late Eocene, Oligocene, Miocene, and most of Pliocene time. In late Pliocene and Pleistocene time, the sea gradually withdrew and was replaced by nonmarine marshes and ponds connected by sluggish streams. The sea generally was deepest along the west side of the basin. Bordering land areas on the west sloped rather steeply toward the basin, at least during times of downwarping within the basin. The east side of the basin was bordered by coastal plains that ascended gradually to hills and mountains farther east.

The filling of the San Joaquin trough during middle Tertiary time has been well outlined by Bandy and Arnal (1969) on the basis of paleoecologic criteria. Their paleobathymetric maps (Bandy and Arnal, 1969, figs. 2, $6,10,14,18,22$ ) show a progressive shallowing of the sea bottom in the Elk Hills area from Oligocene through most of Miocene time. The Wagonwheel Formation and the lower part of the Temblor Formation were laid down at depths probably exceeding 6,000 feet during the Refugian and Zemorrian Stages (Oligocene). The upper part of the Temblor Formation was deposited in water about 6,000 feet deep during the Saucesian Stage (Miocene). The sea was 4,000-6,000 feet deep during the Relizian and Luisian Stages, while the lowermost members of the Monterey Shale, the Gould and Devilwater Shale Members, were laid down. It shallowed rapidly in early Mohnian time when the MacDonald shale was deposited in 2,000-4,000 feet of water and in late Mohnian time when the Elk Hills Shale Member accumulated at a depth of approximately 2,000 feet. Basin-floor turbidites, such as the Main Body B and Western sands in the eastern Elk Hills and North Coles Levee fields, were deposited on the deep sea floor. Channel turbidites, such as the $24 \mathrm{Z}$ and $26 \mathrm{R}$ sands in the Asphalto and western Elk Hills fields, extended down the west flank into the deep basin. Although no paleoecologic data are available on the Reef Ridge Shale, it seems reasonable to assume continued shallowing to the end of Miocene (Delmontian) time.

Thickness and self-potential maps indicate a sediment source to the southwest during deposition of the Tupman Shale Member. The overlying Carman Sandstone Member had, in addition, a probable northeast source of sediment. The increasing importance of an east or northeast source and the effects of a delta encroaching from the east are implied on maps showing the thickness and self potential of the San Joaquin Formation.

Fluviatile and lacustrine conditions predominated during late Pliocene time and into Pleistocene. Coarse sand and gravels of the Tulare Formation were spread across the basin from source areas in the vicinity of the Temblor Range. The Maricopa (Monterey) Shale, which crops out in the Temblor Range, apparently supplied much of the sedimentary material (Woodring and others, 1932, p. 27-28). Crossbedded sandstones in the Tulare Formation appear to be alluvial fans laid down by ephemeral streams coming from the Temblor Range. Beds of mudstone were probably deposited on mudflats at the foot of the alluvial fans. Limy layers suggest flooding of the mudflats and the formation of shallow temporary lakes or playas in which limy deposits were 
formed by evaporation. Alternations of mudflats and alluvial fans suggest periodic changes in climate or more probably periodic uplift of the adjoining highlands that would affect the gradient of the streams (Woodring and others, 1932, p. 30).

Lower Pliocene rocks contain marine fossils in the Tupman Shale Member and in most of the Carman Sandstone Member of the Etchegoin Formation. The seas were probably never more than 600 feet deep during early Pliocene time. The foraminifers Buliminella elegantissima and Eponides exigua found in the Tupman generally indicate neritic or shelf environments in the absence of deeper water types (Berryman, 1973, p. D15). Near the top of the Carman Sandstone Member, Berryman (1973, p. D23) found the freshwater gastropods Fluminicola, which mark the lowest known stratigraphic occurrence of fossils of definite freshwater origin at Elk Hills.

The upper Pliocene San Joaquin Formation contains both marine and nonmarine fossils. Gradual shoaling continued in the Elk Hills region throughout Pliocene time and at times fresh- or brackish-water environments alternated with shallow-water marine environments. Sedimentation was influenced considerably by an ancient delta of the Kern River that encroached on the basin from the northeast. A thin bed (Amnicolite bed) of freshwater gastropods of the genus Amnicola and abundant black ostracodes that are present about 20 feet above the base of the San Joaquin Formation in many wells at Elk Hills (Roberts, 1927, p. 6-7; Berryman, 1973, p. D25) and the presence of the foraminifers Ammonia beccarii and Elphidium hughesi, which are common in the Scalez zone, indicate that brackishwater conditions existed during deposition of most of the Scalez zone sediments. Carbonaceous plant fragments indicating nearby land are common in the upper part of the Scalez zone. Deposition of the Mya sand zone was also characterized by alternating brackish- and fresh-water conditions. Freshwater mollusks, mostly Anodonta sp. and Valvata humerosa, are abundant in the lower middle part of the zone. Freshwater mollusks are also present in a thin bed just below the top of the formation. A 2-foot bed of $M y a$ shells about 72 feet below the top of the San Joaquin Formation probably marks the last marine invasion at Elk Hills.

\section{CHANNEL TURBIDITE SANDSTONES IN THE ELK HILLS SHALE MEMBER OF THE MONTEREY SHALE}

\section{By K. T. Biddle, J. C. Maher, and R. D. Carter}

In central and western Elk Hills field and in the adjacent Asphalto field, the Elk Hills Shale Member of the Monterey Shale, of late Mohnian age, contains two linear sand bodies regarded as channel turbidite deposits. As oil reservoirs, these sand bodies are designated separately as the $24 \mathrm{Z}$ (Asphalto) sand and the 26R sand, although stratigraphically they are approximately equivalent (pls. 8,9) and future drilling may show that they are connected. These elongate sandstones, as now known, are as much as 3 miles long and 1,400 feet thick but only a few thousand feet wide (figs. 35, 36). The $24 \mathrm{Z}$ sand extends from the Asphalto field northeastward across the axis of the Western anticline (fig. 35, pl. 4). The $26 \mathrm{R}$ sand follows the western part of the southwest flank of the Eastern anticline (fig. 36 , pl. 4).

According to Sullwold (1961, p. 63), a turbidite is the sediment deposited by a muddy current that is able to move, even in still water, by virtue of its own muddiness. It is deposited in deep water on the continental slope, rise, or abyssal plain and may be in the form of a channel deposit, a submarine fan, or a more tabular basin-floor deposit. A turbidite is poorly sorted and commonly exhibits graded bedding, repetition of similar sandstone layers separated by the pelagic fine silts and clays, convolute and current bedding, shale inclusions, charcoal fragments, oriented grains, imbricate arrangements of larger clasts, load markings, and a sharp contact with underlying shale.

Probably the first recognition of the deep-water depositional environment of rocks of late Mohnian age in the southern San Joaquin Valley that are equivalent to the Elk Hills Shale Member at Elk Hills was published by Natland (1957, pl. 6) in a chart reproduced here as figure 39: This chart indicates that the Elk Hills Shale Member probably was deposited in marine water $1,000-1,700$ feet deep and very significantly states that most clastic sediments probably were emplaced by submarine landslides and turbidity currents below 200 feet.

Later, Bandy and Arnal (1969, fig. 22) published a paleobathymetric map of the southern San Joaquin Valley at the end of Mohnian time based on the paleoecology of foraminifers. This map shows that waters about 2,000 feet deep were present at Elk Hills when the Elk Hills Shale Member was deposited.

Foraminifers from cores of the $24 \mathrm{Z}$ and $26 \mathrm{R}$ sands examined by R. S. Beck appear to have lived in upper bathyal $(1,000 \pm 600 \mathrm{ft})$ to middle bathyal $(2,000 \pm 1,000$ $\mathrm{ft}$ ) depths, according to the foraminiferal biofacies and time-stratigraphic ranges shown in table 3 of Bandy and Arnal (1969). Therefore it seems reasonable to assume that the water depths were between 1,000 and 3,000 feet during deposition of the Elk Hills Shale Member.

In an excellent summary paper on turbidites in oil exploration, Sullwold (1961, p. 72) pointed out that the 


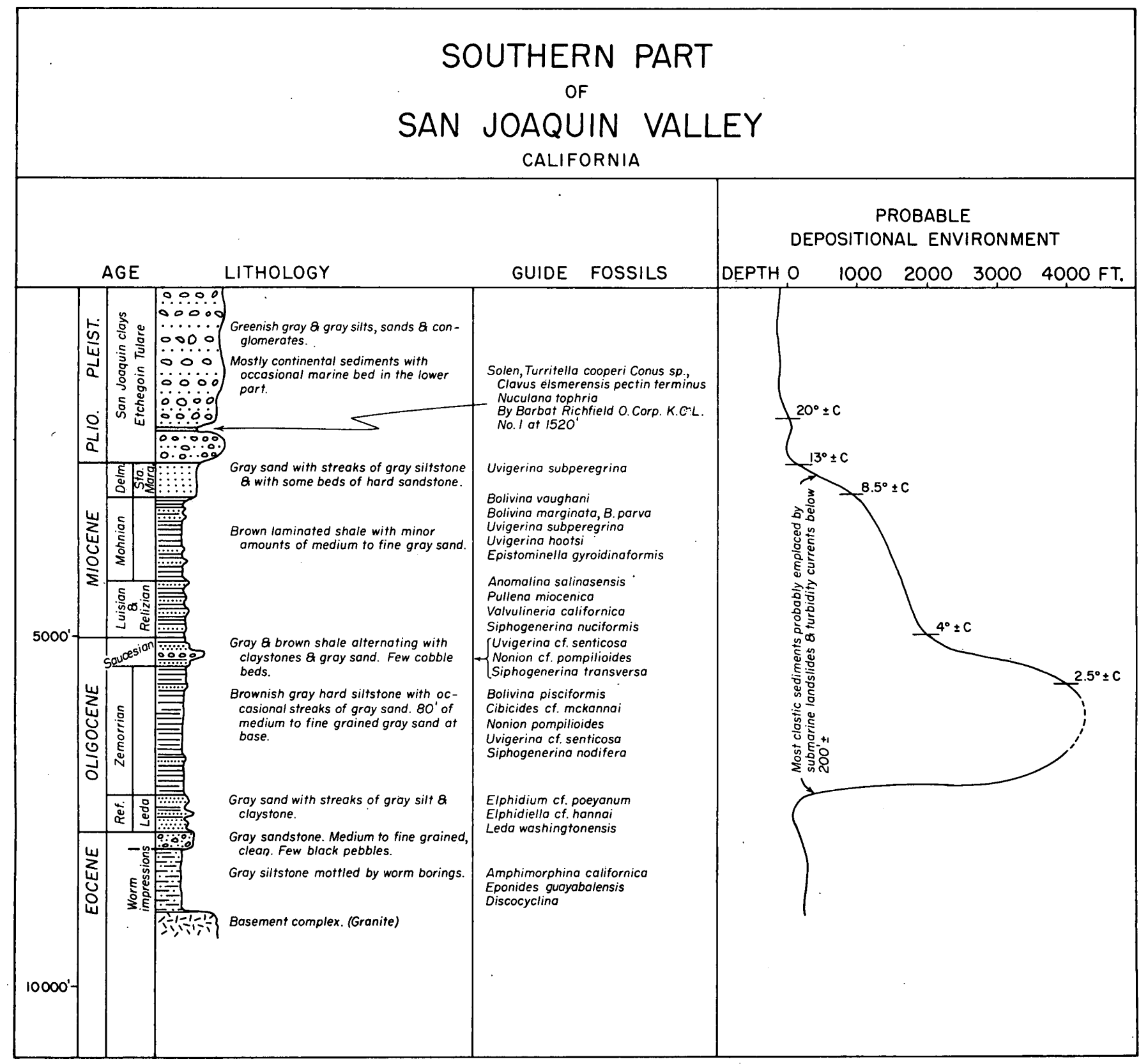

FIGURE 39.-Biostratigraphic section of southern part of San Joaquin Valley (Natland, 1957, pl. 6).

"Stevens Sands" in the southern San Joaquin Valley, which include the $24 \mathrm{Z}$ and $26 \mathrm{R}$ sands at Elk Hills, appear to be a series of turbidites, as judged from their gross geometry within the basin. He emphasized the need for detailed studies to determine if the internal features common to turbidites, such as graded bedding, are present. Others also recognized the "Stevens Sands" as turbidites. Anderson (1963, p. 7) described the "Stevens" sand in the Asphalto field as "a channel-type deposit, the sand having been deposited contemporaneously with the shale that limits its boundaries, rather than in an erosional channel." Foss $(1972$, p. 45) dis- cussed the "Stevens Sands" as basin-floor turbidites in the eastern part of the basin and as channel turbidites in the western part.

In order to support the interpretation of the $24 \mathrm{Z}$ and 26R sands at Elk Hills as channel turbidite sandstones, a detailed study of the sedimentary structures and petrography of the few available cores was made by $\mathrm{K}$. $\mathrm{T}$. Biddle.

\section{SEDIMENTARY STRUCTURES}

Ninety-seven boxes of slabbed cores representing parts of the $24 \mathrm{Z}$ and $26 \mathrm{R}$ sands in 19 wells in the Asphal- 
to and Elk Hills fields were examined for sedimentary structures. These cores represent the $24 \mathrm{Z}$ sand in 11 wells and the $26 \mathrm{R}$ sand in 8 wells.

Sedimentary structures resulting from loading were evident in cores from all wells. Load casts were found at the base of almost all thin sandstone beds at the contact with underlying shales. Tongues of sandstone injected into shale or siltstone, although not common, were noted in several cores. Contorted bedding caused by slumping and deformation (fig. 40) of soft sediment was found in silty and shaly sections of cores from all wells.

Graded bedding, one of the primary criteria for recognition of turbidites, is present in many of the cores (fig. 41). No sequence of graded bedding more than a few inches thick was observed; the apparent lack of thicker graded beds may result from the incompleteness of the cores. Near the lateral limits of the $24 \mathrm{Z}$ sand, the graded bedding has a different character-the grains are much smaller, and the percentage of clay is much greater. Graded bedding is present in a few wells just outside the limits of the $24 \mathrm{Z}$ sand body, but it is more rhythmic and consists solely of very thin siltstone and claystone layers (fig. 42).

None of the cores exhibit a complete Bouma sequence (Bouma, 1962, p. 49) of structures ranging from graded bedding through parallel laminations to pelagic claystone. One piece of core from well 352-26Z shows, from

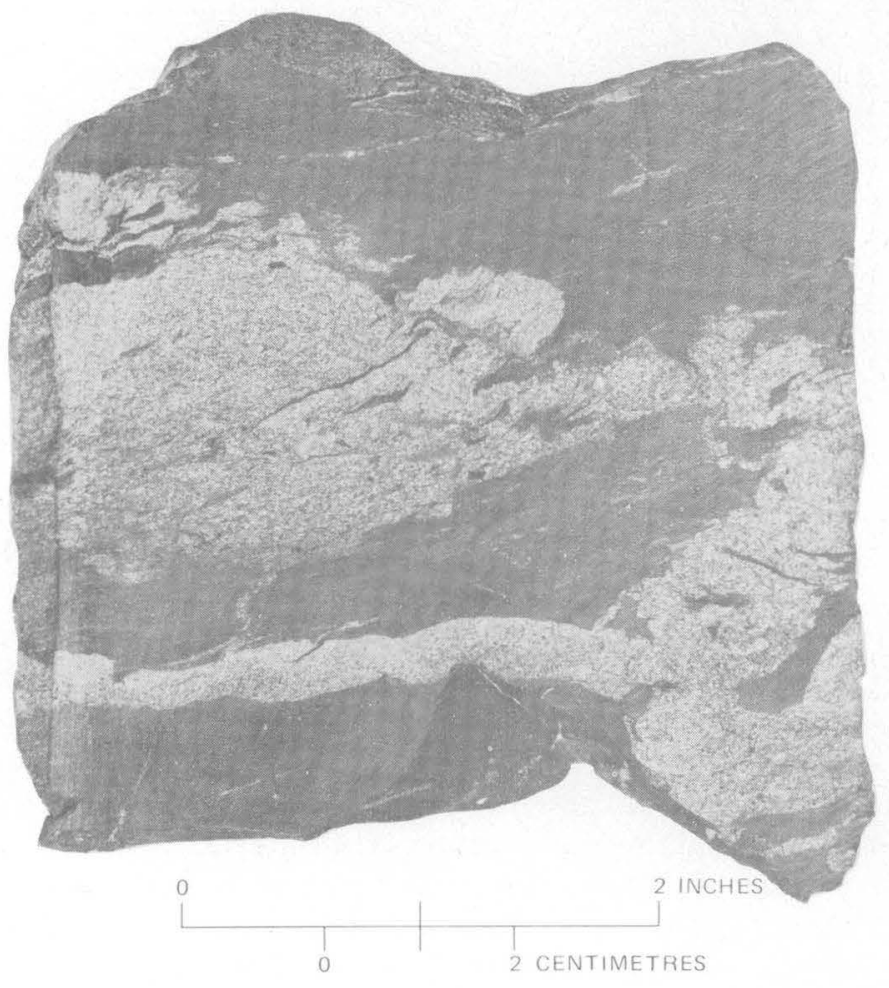

FIGURE 40.-Contorted bedding caused by deformation of unconsolidated sediment (26R sand, depth 6,436 ft, well 312-26R)

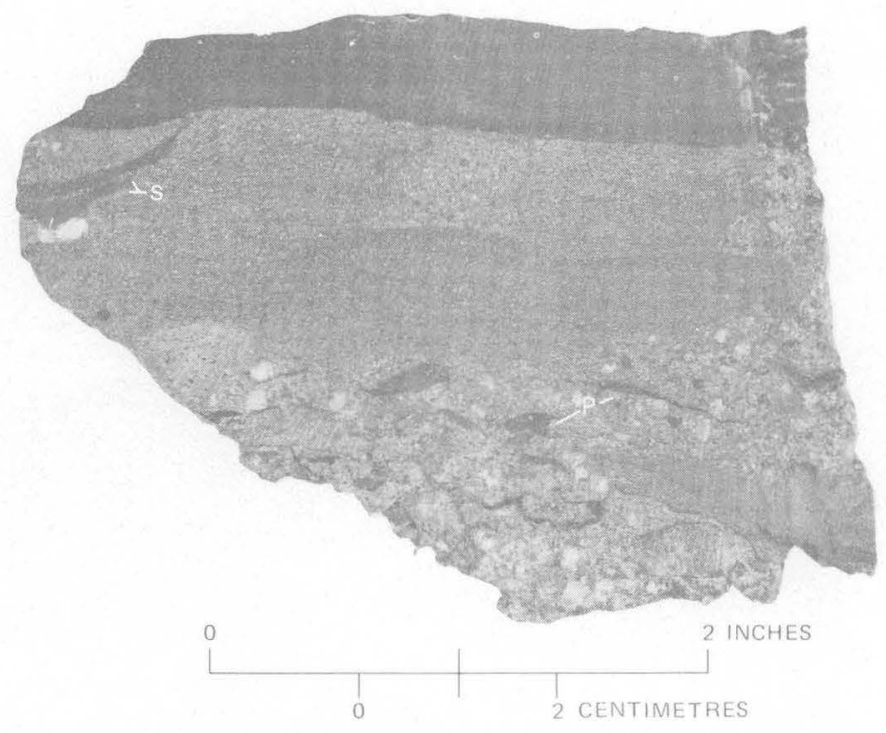

Figure 41.-Graded bedding typical of turbidity current deposits. Note large earbonaceous plant fragments (P), shale chips (S), and dark shale at top (24Z sand, depth $5,776 \mathrm{ft}$, well 382-26Z).

bottom to top, graded bedding, cross-laminations, and graded bedding overlain by shale at the top (fig. 43).

Shale chips and rip-up clasts are common in the cores, particularly at or near the base of very coarse grained sandstones and granule conglomerates (fig. 44). The clasts are generally flattened and deformed, indicating that they were soft at the time of emplacement. Crossbedding of the $24 \mathrm{Z}$ and $26 \mathrm{R}$ sands is mentioned in the original core logs made when the cores were more complete but is present in only a few pieces of the remaining cores.

Cut-and-fill structures less than 2 inches deep are present in some cores, usually at the base of very coarse to medium-grained sandstone beds. Features produced on bedding planes, such as flute casts, bounce marks, and drag marks, are not visible in the slabbed cores, but one flute cast was mentioned in the original core description. Isolated worm burrows and a few features questionably identified as flame structures are present in some cores (fig. 45).

Structureless granule conglomerates as much as 4 feet thick were observed (fig. 46) in some cores. Their relation to shale beds above and below is unknown for lack of complete cores.

\section{PETROGRAPHY}

Sandstone may be classified conveniently on the basis of their differing percentages of three end members-rock fragments, total feldspar, and quartz, quartzite, or chert. These end members form three apexes of a triangle, which is divided into several areas, each representing a type of sandstone. In a similar manner granitic rocks may be classified using as end 


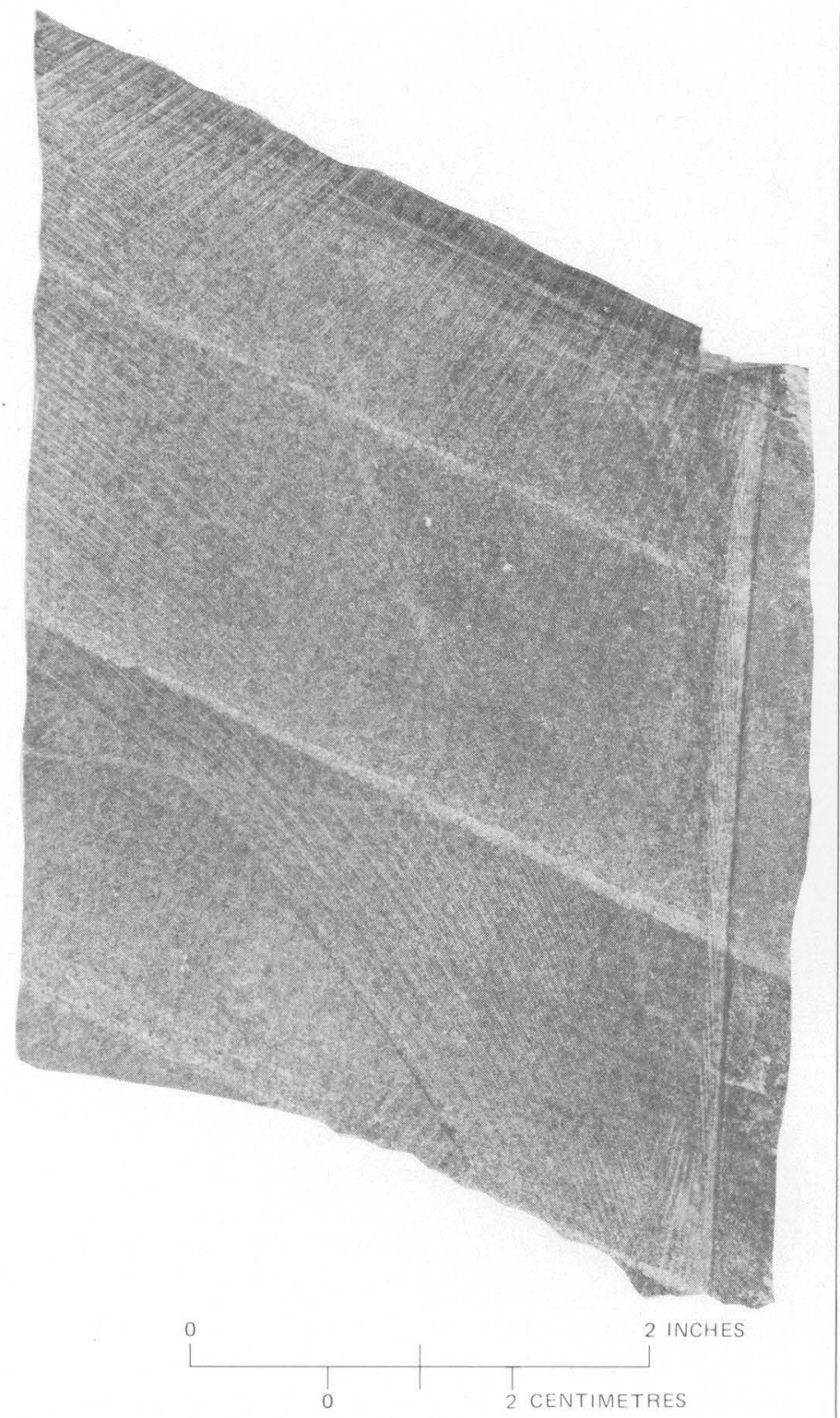

Figure 42.-Graded bedding typical of turbidity current deposits. Note gradation from light siltstone to dark claystone. Fine curved lines are rock-saw marks ( $24 \mathrm{Z}$ sand, depth 6,283 ft, well 311-24Z).

members quartz, plagioclase, and potassium feldspar or perthite. Sandstones in the $24 \mathrm{Z}$ and $26 \mathrm{R}$ sands and cobbles from the $24 \mathrm{Z}$ conglomerate in wells $391 \mathrm{X}-26 \mathrm{Z}$ and 304-26Z were examined in thin section by K. T. Biddle, and the results were plotted on triangular diagrams (figs. 47, 48).

The samples of coarse-grained sandstones and granule conglomerates from different depths and from several wells scattered along the sand bodies were selected for petrographic examination. The larger size fractions were chosen because they generally contain more lithic fragments than the finer grained clastic rocks and therefore better represent the rock types of the source areas. Ten thin sections of $24 \mathrm{Z}$ sand cores in 9

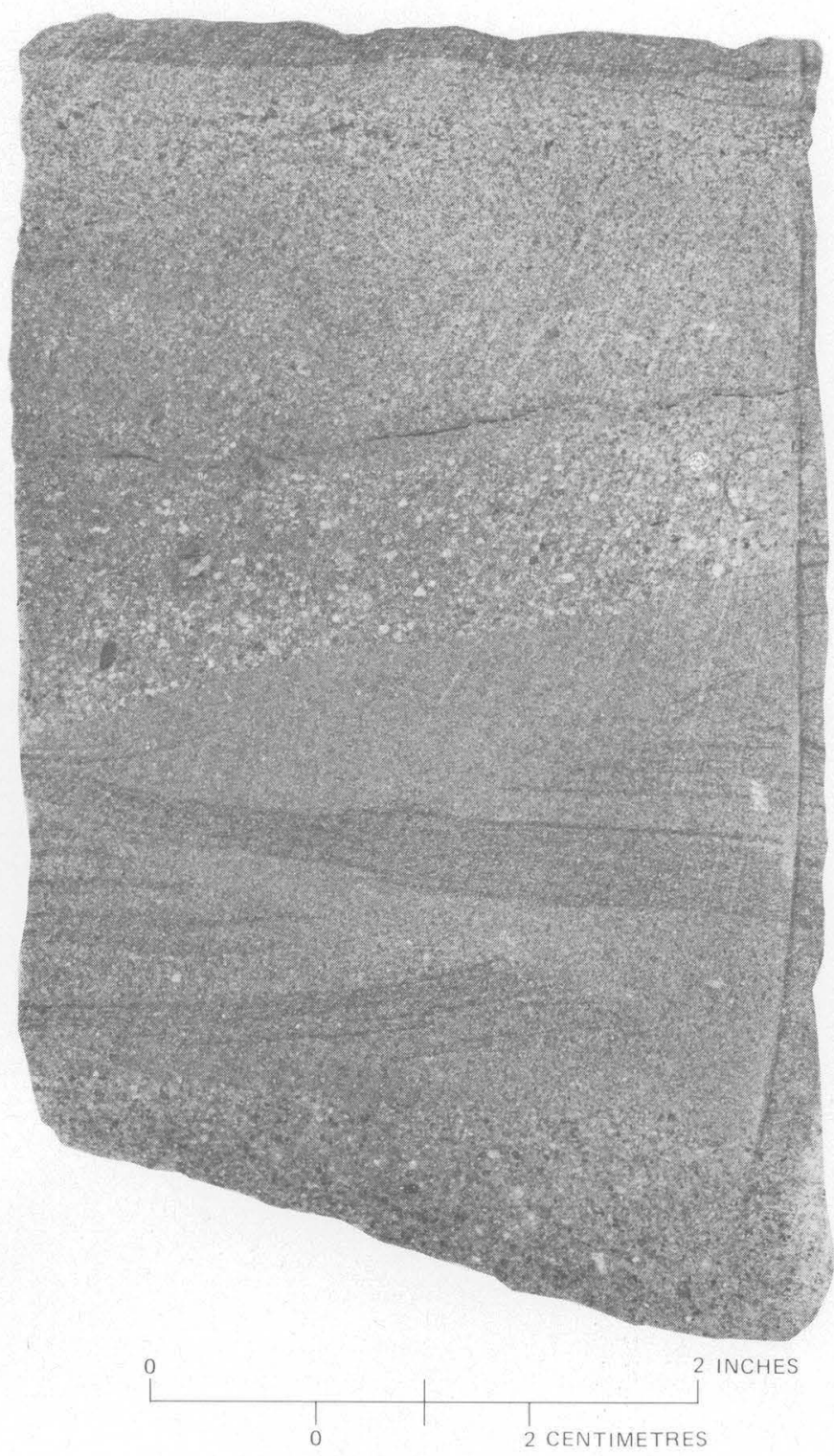

FIGURE 43.-Graded bedding typical of turbidity current deposits. Note cross-laminations in lower half and dark shale layer at top (24Z sand, depth 5,572 ft, well 352-26Z).

wells, 4 thin sections of $26 \mathrm{R}$ sand cores in 4 wells, and 11 thin sections of cobbles from the $24 \mathrm{Z}$ conglomerates in wells $391 \mathrm{X}-26 \mathrm{Z}$ and $304-26 \mathrm{Z}$ were studied. Grain sizes were determined using the Wentworth size classification; the degree of rounding, sorting, and packing was visually estimated. The term "textural maturity" is used in this discussion to refer to the degree of sorting and the amount of matrix material. A texturally mature sandstone is well sorted, and its matrix is less than 5 percent; a texturally immature sandstone is poorly sorted, and its matrix amounts to more than 5 percent.

The sandstones of the $24 \mathrm{Z}$ and $26 \mathrm{R}$ sand bodies are mostly poorly to moderately sorted subangular to angu- 


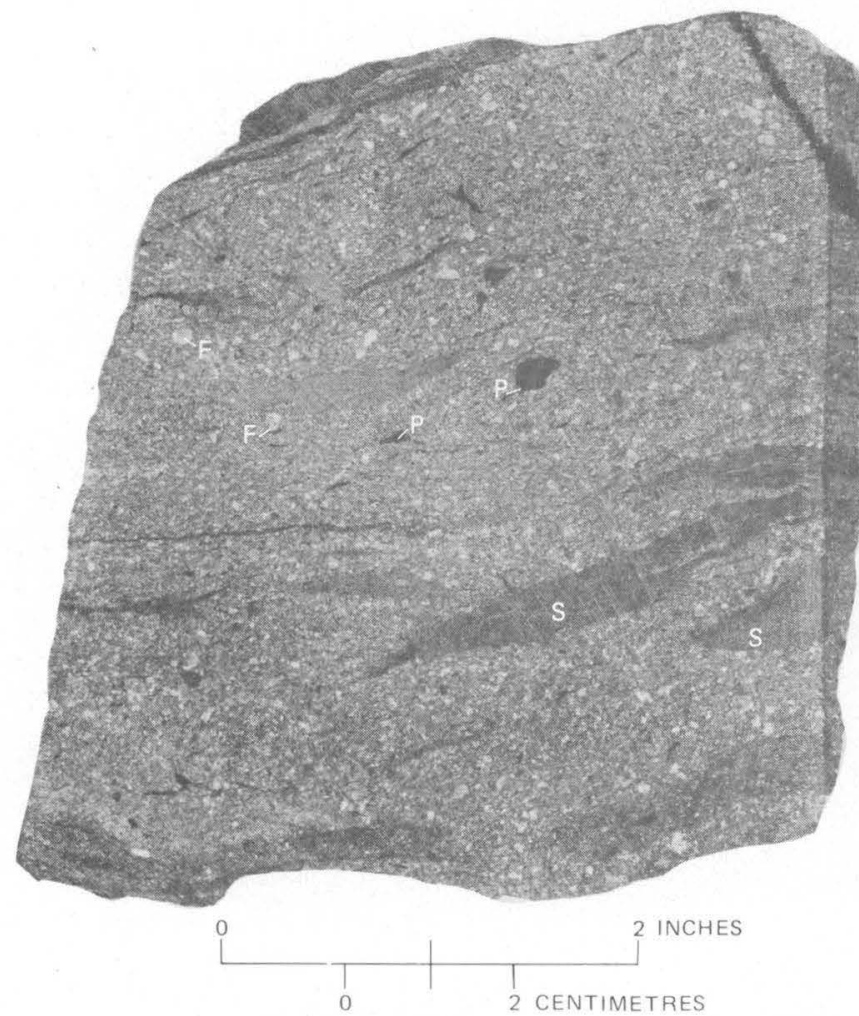

Figure 44.-Flattened rip-up clasts of shale (S) typical of turbidites. Note large carbonaceous plant fragments $(\mathrm{P})$ near center of core and the "floating" very coarse sand grains (E) (26R sand, depth 6,988ft, well 352-27R)

lar moderately to tightly packed texturally immature feldspathic litharenites to lithic arkoses (fig. 47). One sample of lithic subarkose was noted.

Granitic rock fragments, the major component of almost every sandstone examined, make up as much as 40 percent of the total clasts. The nearly uniform composition of these rock fragments consists of subequal amounts of quartz, plagioclase, and potassium feldspar. The plagioclase ranges from oligoclase to andesine. The major ferromagnesian mineral is biotite, which is present only in accessory amounts. Traces of zircon and apatite were observed.

Quartz fragments are next in abundance in most samples, although the percentage of feldspar fragments exceeds quartz in a few samples. Most of the quartz clasts exhibit undulatory extinction.

Third in abundance are grains of plagioclase and potassium feldspar in subequal amounts. The plagioclase ranges from albite to andesine; the potassium feldspars are microcline and orthoclase. Small amounts of orthoclase-albite perthite are present also.

The remainder of the framework grains are made up by minor amounts of several rock types and individual minerals, of which biotite is the most common. Musco-

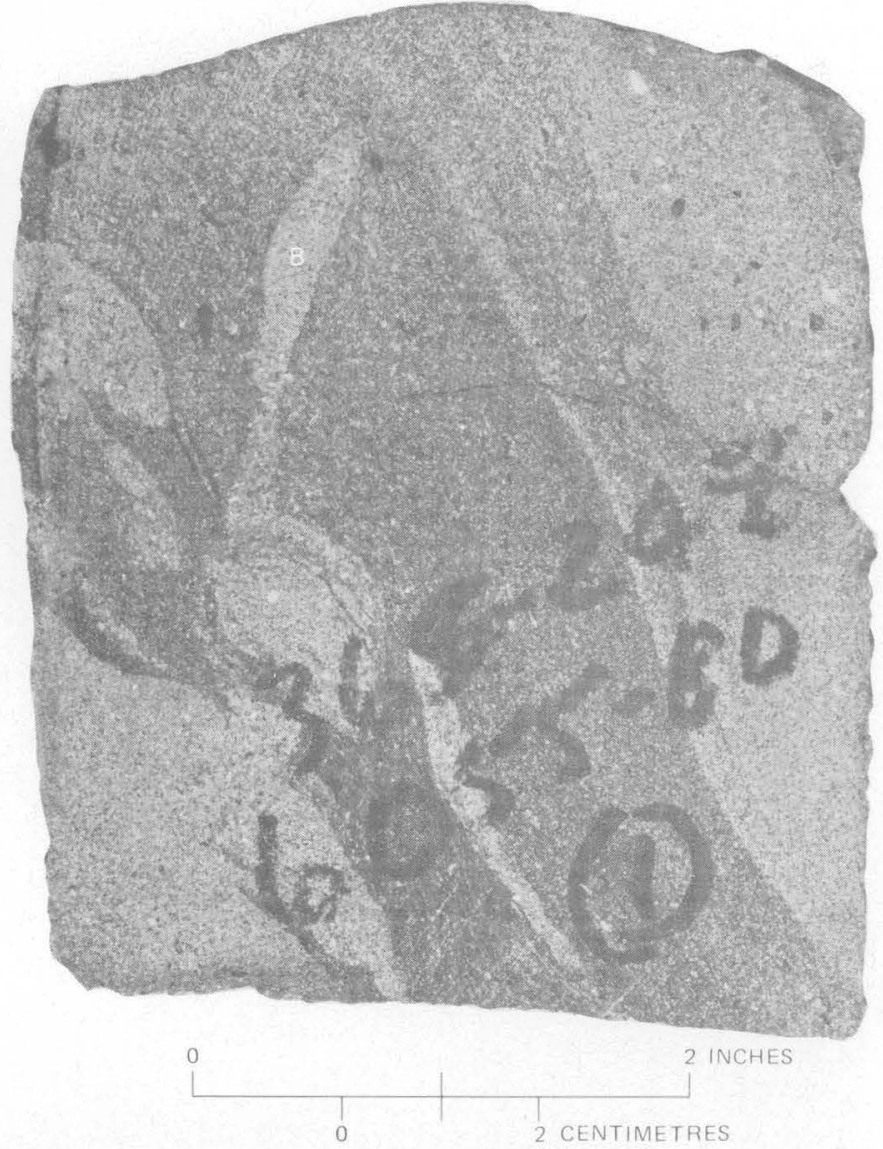

Figure 45.-Worm burrow (B) in fine-grained sandstone (24Z sand, depth $6,071 \mathrm{ft}$, well $366-24 Z$ ).

vite, rounded glassy microlitic volcanic fragments, silicic hornfels with minor amounts of tourmaline, coarsely crystalline marble, muscovite-biotite schist, chert, and siliceous shale fragments also were noted.

Carbonaceous plant fragments are present in all samples in amounts ranging from a trace to 2 percent. These carbonaceous fragments are usually small tabular flakes alined parallel to the bedding planes. Large irregular carbonaceous plant fragments are also common. Many of these occur by themselves, but a few are found in swarms (fig. 49).

The matrix, which cements the grains together, makes up between 5 and 10 percent of the rock. It is composed of silicified clays, some of which is opaline, with different proportions of silt. Authigenic calcite fills the pores in some sandstone samples.

The cobbles from the $24 \mathrm{Z}$ conglomerates in wells $391 \mathrm{X}-26 \mathrm{Z}$ and $304-26 \mathrm{Z}$ are probably the same as the granitic rock fragments in the sandstones. The cobbles are mostly quartz monzonite followed closely in abundance by granite (fig. 42). One cobble consisted of granodiorite, and one of coarsely crystalline marble. 


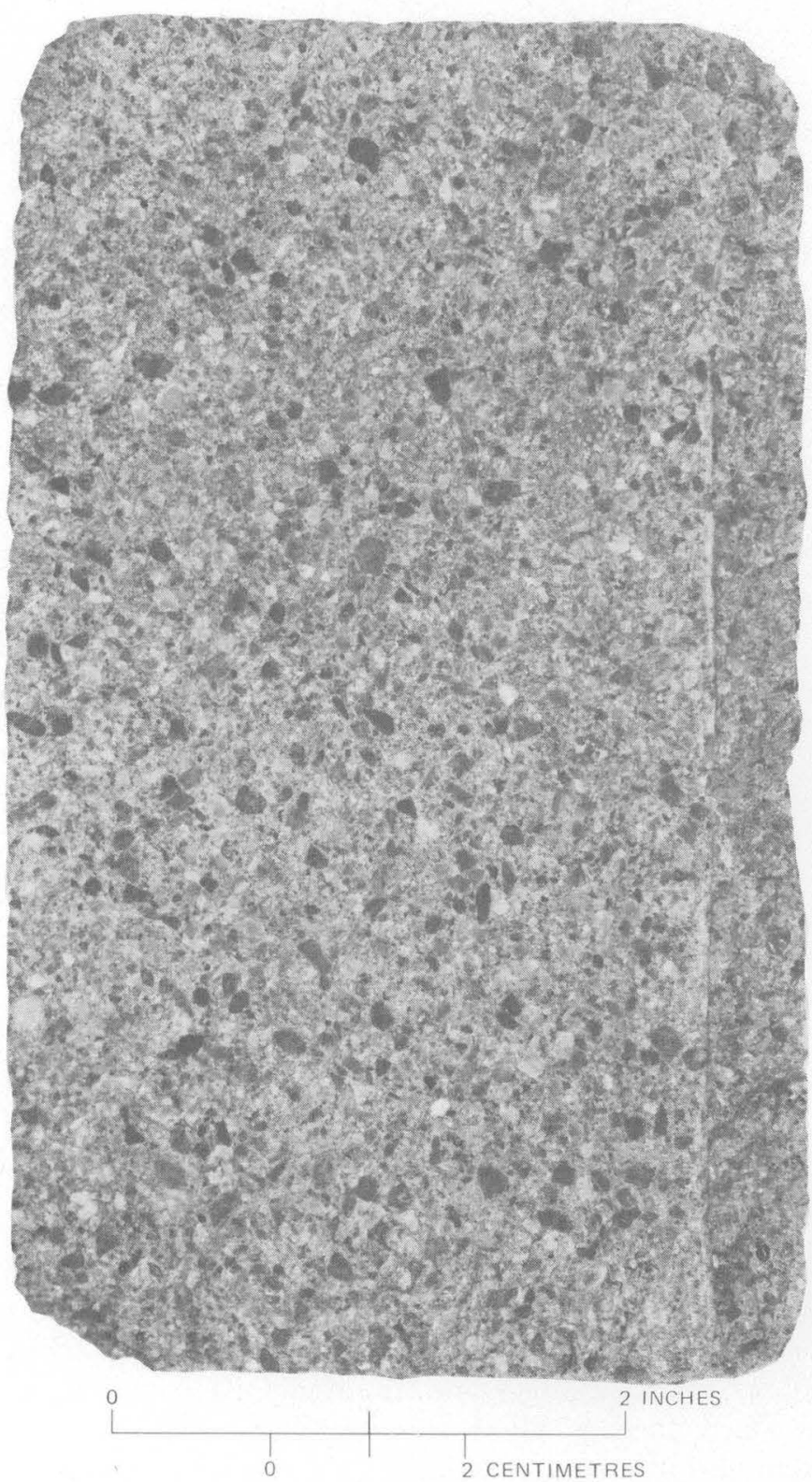

Figure 46.--Structureless granule conglomerate (24Z sand, depth $5,818 \mathrm{ft}$, well $363-24 \mathrm{Z}$ )

\section{SOURCE AND DEPOSITION}

The striking similarity in composition of the sandstones in the $24 \mathrm{Z}$ and $26 \mathrm{R}$ sand bodies suggests that they shared a common source area, where the terrane was mainly quartz monzonite and granite and some granodiorite, all of which are poor in ferromagnesian minerals. At the time of deposition of the $24 \mathrm{Z}$ and $26 \mathrm{R}$ sands, the Sierra Nevada to the east was supplying sediment to the San Joaquin basin. The terrane, however, was predominantly quartz diorite and would have produced sediment richer in ferromagnesian minerals than that composing the $24 \mathrm{Z}$ and $26 \mathrm{R}$ sands. A source

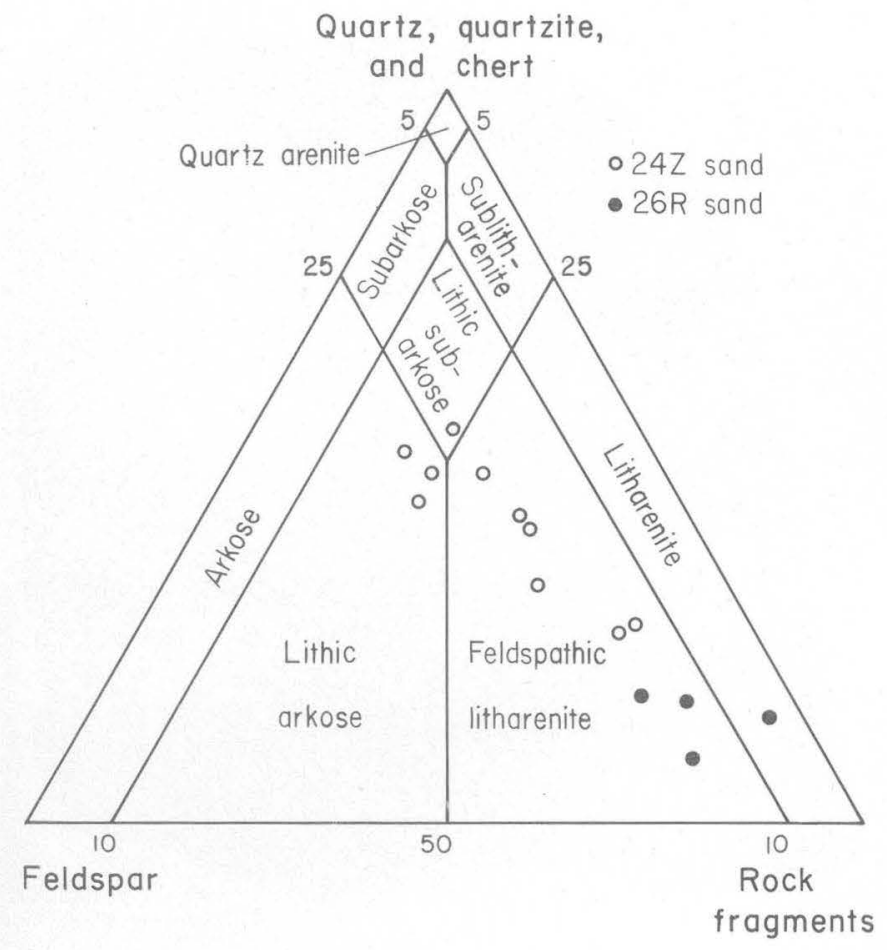

Figure 47.-Composition of sandstones in thin sections of cores from the $24 \mathrm{Z}$ and $26 \mathrm{R}$ sands. Classification of sandstones after McBride (1963).

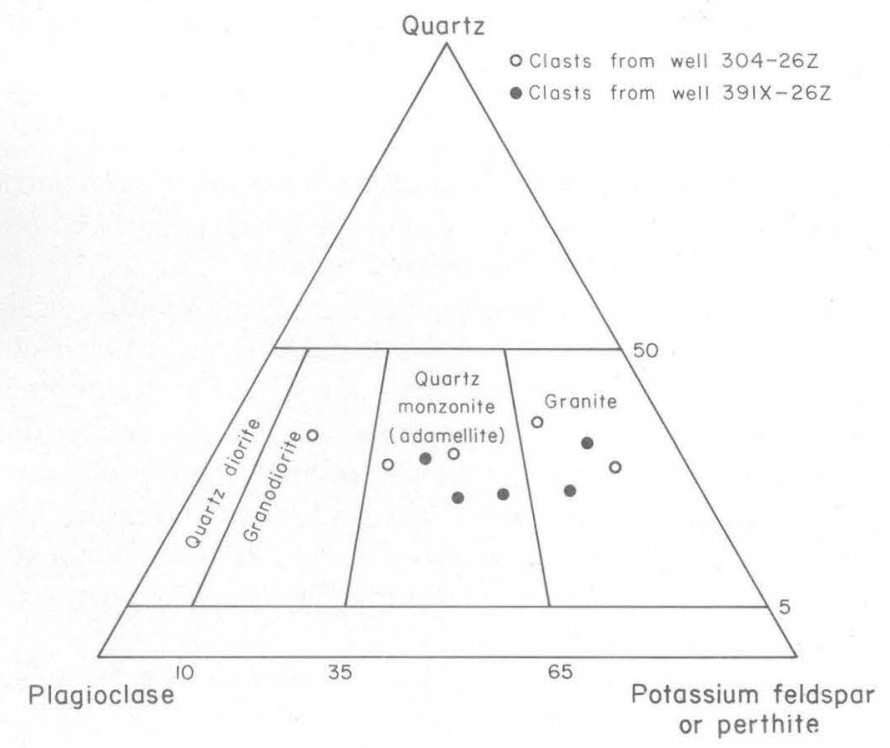

FiguRE 48.-Composition of granitic rock clasts in cores of $24 \mathrm{Z}$ sand. Classification of granitic rocks after Moore (1959).

area to the south of Elk Hills seems unlikely in view of the southwest seaway from the basin to the ocean postulated by Bandy and Arnal (1969, fig. 22).

A suitable source terrane, poor in mafic rocks and ferromagnesian minerals, may have been present west of Elk Hills across the San Andreas fault during deposition of the Elk Hills Shale Member. Later movement of 


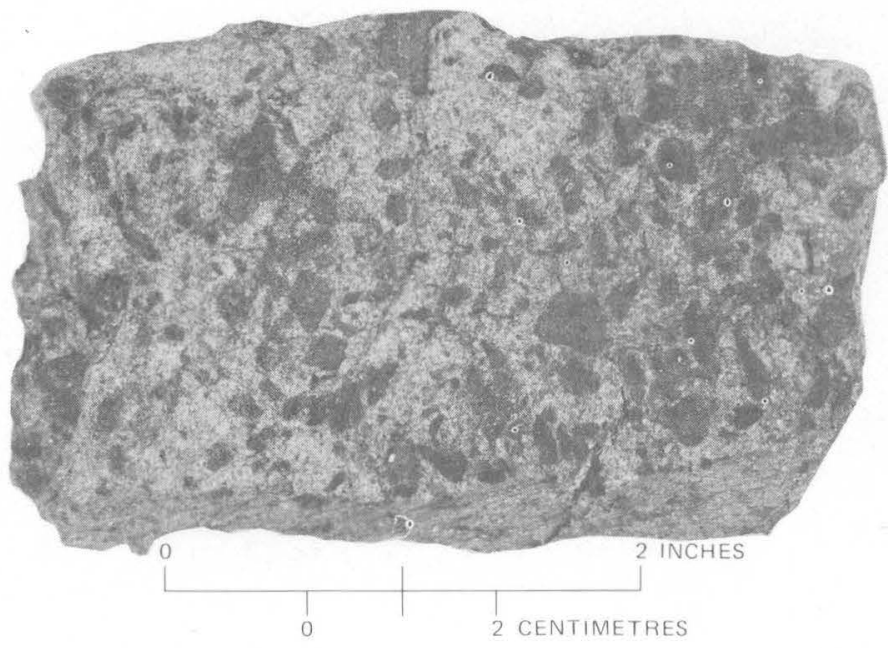

FIGURE 49.-Large carbonaceous plant fragments in fine-grained sandstone probably deposited in deep water (26R sand, depth 6,732 $\mathrm{ft}$, well $312-36 \mathrm{R}$ )

the San Andreas fault would have displaced it northwestward perhaps some 80 miles, a displacement suggested by Dibblee (1966, p. 378). In his discussion of the upper Miocene Reef Ridge Shale exposed in the Temblor Range west of Elk Hills, Dibblee stated

to the southwest within this range the shale intertongues into a coarse breccia facies of granitic rock, schist and marble detritus ${ }^{* * *}$ Obviously this coarse detritus was derived from an adjacent mountain range of crystalline rocks that must have been prominent in the area directly west across the fault in late Miocene time. The nearest possible source of such crystalline rocks without a cover of upper Miocene sediments west of the fault is now in the Gabilan Range some 80 miles to the northwest, suggesting a right-lateral displacement of that amount since late Miocene time.

The general composition of the Gabilan Range is sufficient to supply the required type of sediment for the $24 \mathrm{Z}$ and the 26R sands. Compton (1966, p. 284-285) stated that "Granitic rocks form the great bulk of the range***. The exposed plutonic rocks are dominantly silicic, ranging from biotite granodiorite to adamellite and granite." He also stated that "The metamorphic rocks are marbles, quartzites, schists and calc-silicate rocks***." Therefore, it appears that the sediment found in the $24 \mathrm{Z}$ and $26 \mathrm{R}$ sands probably was derived from the west and that this source area is presently about 80 miles to the northwest of Elk Hills in the Gabilan Range.

The primary mechanism for the deposition of sediment in the $24 \mathrm{Z}$ and $26 \mathrm{R}$ channels appears to have been turbidity current flows. The suite of sedimentary structures found in the cores of these sands is similar to those that have been described from turbidity current deposits throughout the world. The combination of the grain sizes, the textural and mineralogical immaturity of the sandstones, and the abundance of carbonaceous plant fragments and large flakes of biotite also suggest a form of mass sediment transport into deep water.

Several structures in the cores indicate that some material in the $24 \mathrm{Z}$ and $26 \mathrm{R}$ sands was deposited by slumping. These slump deposits may represent either new sediment or material reworked from the channel.

The thick very coarse grained sandstones that are found in the $24 \mathrm{Z}$ and $26 \mathrm{R}$ sands in some wells may result from mass sediment flow other than turbidity currents-possibly grain flows of the type proposed by Stauffer (1967) to explain some massive sandstone deposits in the Santa Ynez mountains of southern California. Inasmuch as the incomplete cores of these very coarse grained sandstones exhibit no sedimentary structures, the method of their deposition is uncertain.

The $24 \mathrm{Z}$ and the $26 \mathrm{R}$ sands were probably deposited in a channel crossing a deep-water submarine fan. The finer material spilled over the channel edges and produced the graded siltstone and shale seen in a few wells just outside the $24 \mathrm{Z}$ and the $26 \mathrm{R}$ channel boundaries.

\section{OIL AND GAS}

\section{PRODUCTIVE ZONES}

Petroleum is produced from five oil and gas zones at Elk Hills (table 4), four of them consisting of several reservoirs in close stratigraphic succession grouped together for economic reasons and engineering convenience. The fifth and stratigraphically deepest zone, the Santos Shale Member, has been found productive in only one well to date. The upper three zones have been defined specifically, or by usage, in reports of the Elk Hills Engineering Committee. The fourth and fifth zones have not been defined by the committee because the oil produced from them within NPR-1 comes from beneath Navy lands only and they are not subject to the unit agreement at this time. The five oil and gas zones may be described briefly as follows:

1. The Dry Gas Zone, the uppermost zone, consists of all "dry gas bearing formations above the top of the Lower Scales (sic) marker bed" (Elk Hills Engineering Committee, 1957a, p. 4). The lower Scalez marker bed is a fossil horizon in the lower part of the San Joaquin Formation of Pliocene age. The reservoirs in this upper zone are thin very lenticular loosely cemented sandstones with relatively high permeabilities.

2. The Shallow Oil Zone includes "all oil and gas bearing formations of Pliocene age above the Reef Ridge Shale" but "does not include any of the dry gas bearing formations above the top of the Scales (sic) marker bed" (Elk Hills Engineering Committee, $1957 \mathrm{a}$, p. 4). The numerous reservoirs in this zone are thin lenticular sandstones with relatively 
TABLE 4.-Oil and gas reservoirs, producing zones, production, and reserves of Naval Petroleum Reserve No. 1, 1972 [Source: Annual report calendar year 1972, Naval Petroleum Reserves 1 and 2, Naval Petroleum Reserve, Elk Hills, California]

\begin{tabular}{|c|c|c|c|c|c|c|c|}
\hline \multirow{2}{*}{$\begin{array}{l}\text { Oil and gas } \\
\text { zones }\end{array}$} & \multirow{2}{*}{$\begin{array}{l}\text { Oil and gas } \\
\text { production zones of } \\
\text { Elk Hills Engineering } \\
\text { Committee (1957a, b) }\end{array}$} & \multirow{2}{*}{$\begin{array}{c}\text { Cumulative } \\
\text { production } \\
\text { to December } 31 \\
1972\end{array}$} & \multirow{2}{*}{$\begin{array}{l}\text { Estimated } \\
\text { remaining } \\
\text { recoverable } \\
\text { reserves }\end{array}$} & \multirow{2}{*}{$\begin{array}{l}\text { Estimated } \\
\text { original } \\
\text { recoverable } \\
\text { reserves }\end{array}$} & \multicolumn{3}{|c|}{ Stratigraphic position } \\
\hline & & & & & Member & Formation & Series \\
\hline Mya sand zone. & $\begin{array}{l}\text { Dry Gas Zone, } \\
5 \text { producible wells. }\end{array}$ & $\begin{array}{l}99,766,848 \text { thousand } \\
\text { cubic feet gas. }\end{array}$ & $\begin{array}{l}220,192,762 \text { thousand } \\
\text { cubic feet gas. }\end{array}$ & $\begin{array}{l}\text { 319,959,610 thousand } \\
\text { cubic feet gas. }\end{array}$ & & $\begin{array}{c}\text { San Joaquin } \\
\text { Formation. }\end{array}$ & \multirow{3}{*}{ Pliocene. } \\
\hline \multirow{2}{*}{$\begin{array}{l}\text { Scalez sand zone, } \\
\text { Mulinia sand zone, } \\
\text { Wilhelm sand zone, } \\
\text { Gusher sand zone, } \\
\text { Calitroleum sand } \\
\text { zone, } \\
\text { Olig sand zone. }\end{array}$} & \multirow[t]{2}{*}{$\begin{array}{l}\text { Shallow Oil } \\
\text { Zone, } 722 \\
\text { producible wells. }{ }^{1}\end{array}$} & \multirow{2}{*}{$\begin{array}{l}280,169,912 \text { barrels } \\
\text { oil (adjusted } \\
\text { to unit production } \\
\text { records). }\end{array}$} & \multirow[t]{2}{*}{$\begin{array}{l}318,489,715 \text { barrels } \\
\text { oil. }\end{array}$} & \multirow[t]{2}{*}{$\begin{array}{l}598,659,627 \text { barrels } \\
\text { oil. }\end{array}$} & $\begin{array}{l}\text { Carman } \\
\text { Sandstone } \\
\text { Member. }\end{array}$ & \multirow{2}{*}{$\begin{array}{l}\text { Etchegoin } \\
\text { Formation. }\end{array}$} & \\
\hline & & & & & $\begin{array}{l}\text { Tupman Shale } \\
\text { Member. }\end{array}$ & & \\
\hline & & & & & & $\begin{array}{l}\text { Reef Ridge } \\
\text { Shale. }\end{array}$ & \multirow{6}{*}{ Miocene. } \\
\hline \multirow[t]{3}{*}{$\begin{array}{l}\text { N zone (24Z sand), } \\
\text { A zone (26R sand), } \\
\text { B zone (B sands), } \\
\text { C zone, } \\
\text { D zone. }\end{array}$} & $\begin{array}{l}\text { Stevens Oil } \\
\text { Zone, } 253 \\
\text { producible wells.' }\end{array}$ & $\begin{array}{l}\text { 14,092,070 barrels } \\
\text { oil. }\end{array}$ & $\begin{array}{l}683,988,638 \text { barrels } \\
\text { oil. }^{2}\end{array}$ & $\begin{array}{l}698,080,708 \text { barrels } \\
\text { oil. }{ }^{2}\end{array}$ & $\begin{array}{l}\text { Elk Hills } \\
\text { Shale } \\
\text { Member. }\end{array}$ & \multirow{2}{*}{$\begin{array}{l}\text { Monterey } \\
\text { Shale. }\end{array}$} & \\
\hline & & & & & $\begin{array}{l}\text { Gould and Devil- } \\
\text { water Shale } \\
\text { Members. }\end{array}$ & & \\
\hline & & & & & $\begin{array}{l}\text { Media Shale } \\
\text { Member. }\end{array}$ & \multirow{3}{*}{$\begin{array}{l}\text { Temblor } \\
\text { Formation. }\end{array}$} & \\
\hline Carneros oil zone. & $\begin{array}{l}\text { Carneros Oil } \\
\text { Zone, } 7 \\
\text { producible wells.', } 2\end{array}$ & $\begin{array}{l}368,572 \text { barrels } \\
\text { oil. }\end{array}$ & $\begin{array}{l}4,901,428 \text { barrels } \\
\text { oil. }^{2}\end{array}$ & $\begin{array}{l}5,270,000 \text { barrels } \\
\text { oil. }^{2}\end{array}$ & $\begin{array}{l}\text { Carneros } \\
\text { Sandstone } \\
\text { Member. }\end{array}$ & & \\
\hline Santos oil zone. & $\begin{array}{l}\text { Santos Zone } \\
\text { (Railroad Gap field } \\
\text { only), } 1 \text { standing } \\
\text { well. }\end{array}$ & $\begin{array}{l}21,494 \text { barrels } \\
\text { oil. }\end{array}$ & No estimate. & No estimate. & $\begin{array}{l}\text { Santos } \\
\text { Shale Member. }\end{array}$ & & \\
\hline
\end{tabular}

'Including production from Asphalto field.

${ }^{2}$ Does not include Railroad Gap field; reserve studies have not been made.

high permeabilities in the Etchegoin and lower San Joaquin Formations.

3. The Stevens Oil Zone contains "all oil and gas bearing formations of upper Miocene age within the stratigraphic interval between the top of the Reef Ridge Shale and the top of Valvulineria californica or associated faunas of middle Miocene age" (Elk Hills Engineering Committee, 1957b, p. 4). The reservoirs in this zone are thick lenticular to tabular sheet sandstones and thick intervals of fractured siliceous shale in the upper part of the Elk Hills Shale Member of the Monterey Shale. Both types of reservoirs have relatively low permeabilities.

4. The Carneros Oil Zone consists of one to three thick Miocene sandstones in the uppermost part of the Temblor Formation.

5. The Santos Oil Zone consists of a sequence of calcareous shale beds at the top of the Santos Shale Member of the Temblor Formation. It produces oil in only one well (518-14Z), which is located in the Railroad Gap field within the Naval Petroleum Reserve. No estimates of zone reserves or potential are available.

\section{HISTORY OF DEVELOPMENT}

The discovery of oil in the Shallow Oil Zone at Elk Hills by the Standard Oil Company (California) No. 1 Hay well in 1919 was followed in 1920 by the completion of a large producing well (1-36S) 6 miles east of the discovery well. It produced at a rate of more than 5,000 barrels of oil per day. Thereafter, drilling in the eastern part of Elk Hills proceeded rapidly, and more than 200 wells were producing from the Shallow Oil Zone by 1929 (Gooch and Adams, 1955, p. 13).

Few wells were drilled in the following years until oil was discovered in the Stevens Oil Zone in August 1941. From 1941 to 1944, eight wells were drilled to test this deeper productive zone (Elk Hills Engineering Committee, $1957 \mathrm{~b}$, p. 5)

In June 1944, Congress authorized development of the NPR-1 to increase production for wartime needs, and in the ensuing 15 months 317 development wells were drilled, most of them to the Shallow Oil Zone. A comprehensive exploratory drilling program to delineate the productive limits of both the Shallow and Stevens Zones was started in July 1945 (Gooch and Adams, 1955, p. 14). In 1948, after the exploration phase, a readiness development program for the Ste- 
vens Zone was initiated. This resulted in the drilling of 203 wells (Elk Hills Engineering Committee, 1957b, p. 5). The last large-scale drilling program prior to 1973 occurred from 1951 to 1954 , when 178 wells, most of them directed to the Shallow Oil Zone, were drilled and completed.

The discovery of the Asphalto field (fig. 35) in 1963 forced the Navy to drill and produce 25 wells in section $26 \mathrm{Z}$ to prevent the drainage of oil in the Stevens and Carneros Oil Zones from NPR-1. As a result of this production, it was necessary also to drill several wells in section $24 \mathrm{Z}$ to determine whether or not the reservoirs were continuous between the Asphalto field and the Elk Hills field. They were found to be continuous, and water injection was started in two of the wells in section $24 \mathrm{Z}$ to prevent the loss of oil from Elk Hills into the Asphalto field.

The Railroad Gap field (fig. 37) was found in 1964 in section $15 Z$ by Standard Oil Company of California. Subsequently, four wells were drilled by the Navy in section $14 \mathrm{Z}$ in order to prevent wells in this field from draining the Elk Hills structure.

In addition to the well-drilling activity just described, wells have been drilled from time to time for replacement, remedial programs, and for gathering data. Oiland gas-development drilling at Elk Hills proceeded generally from east to west and from shallow to deeper reservoirs.

\section{SANTOS OIL ZONE}

The oldest beds that now produce petroleum in NPR -1 are probably thin sandstones in the upper part of the Santos Shale Member at a depth of 8,000-8,042 feet. The only well (518-14Z in Railroad Gap field) completed in this zone was drilled to a depth of 10,050 feet but was not cored through the productive interval, and so the lithology is not known with certainty. A sidewall core taken 50 feet below the productive interval is described in the drilling records as dark-brown calcareous shale. Cores of upper Santos shale in two other wells in the Elk Hills field contain thin oil-stained sandstones. It may be reasonable to assume, therefore, that similar sandstones are reservoirs in well 518-14Z. Analyses of the cores from the two other wells show average porosities of 4 and 20 percent and average permeabilities of 0 and 19 millidarcys, respectively. (table 5 ). The total production from the single completion in this zone in 1965 amounted to 21,494 barrels-all produced during testing programs. The well has been shut-in for several years, and reserve estimates have not been made. The only other wells producing from the Santos Oil Zone in the southern San Joaquin Valley region are in the North Antelope Hills oil field in Antelope Valley (fig. 34).
TABLE 5.-Porosity and permeability for cores from wells drilled in Naval Petroleum Reserve No. 1

\begin{tabular}{|c|c|c|c|c|c|c|c|}
\hline \multirow{2}{*}{ Well } & \multicolumn{2}{|c|}{ Cored depth } & \multirow{2}{*}{$\begin{array}{l}\text { Number of } \\
\text { analyses }\end{array}$} & \multicolumn{2}{|c|}{$\begin{array}{l}\text { Permeability, in } \\
\text { millidarcys }\end{array}$} & \multirow{2}{*}{\multicolumn{2}{|c|}{$\frac{\begin{array}{c}\text { Porosity, in } \\
\text { percent }\end{array}}{\text { Range Average }}$}} \\
\hline & From & n To & & $\overline{\text { Range }}$ & Average & & \\
\hline \multicolumn{8}{|c|}{ TULARE FORMATION } \\
\hline $\begin{array}{l}324-19 R+\ldots . \\
64-34 R\end{array}$ & $\begin{array}{l}993.0 \\
919.5 \\
972.5\end{array}$ & $\begin{array}{l}1,008.0 \\
\cdots \cdots . .\end{array}$ & $\begin{array}{l}8 \\
1 \\
1\end{array}$ & $\begin{array}{l}2-8,150 \\
63 \\
0\end{array}$ & $\begin{array}{r}4,030 \\
63 \\
0\end{array}$ & $\begin{array}{c}34-40 \\
32 \\
30\end{array}$ & $\begin{array}{l}37 \\
32 \\
30\end{array}$ \\
\hline \multicolumn{8}{|c|}{$\begin{array}{l}\text { SAN JOAQUIN FORMATION } \\
\text { Mya sand zone }\end{array}$} \\
\hline 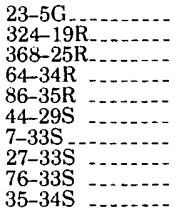 & $\begin{array}{l}1,851.5 \\
1,021.5 \\
1,134.5 \\
1,039.5 \\
1,915.5 \\
2,701.5 \\
1,813.5 \\
1,846.5 \\
1,957.5 \\
2,751.0\end{array}$ & $\begin{array}{l}1,871.5 \\
1,674.0 \\
2,021.5 \\
2,082.5 \\
2,371.5 \\
2,879.0 \\
2,351.5 \\
2,353.5 \\
2,489.5\end{array}$ & $\begin{array}{r}4 \\
10 \\
51 \\
140 \\
107 \\
18 \\
30 \\
52 \\
20 \\
1\end{array}$ & $\begin{array}{r}030-4,900 \\
0-6,810 \\
29-2,870 \\
0-5,380 \\
3-5,370 \\
28-1,925 \\
0-11,850 \\
50-3,810 \\
17-11,400 \\
917\end{array}$ & $\begin{array}{r}3,305 \\
1,831 \\
505 \\
286 \\
986 \\
617 \\
1,346 \\
1,149 \\
1,807 \\
917\end{array}$ & $\begin{array}{c}38-41 \\
28-45 \\
26-40 \\
29-41 \\
26-47 \\
30-37 \\
32-47 \\
33-43 \\
29-43 \\
33\end{array}$ & $\begin{array}{l}39 \\
37 \\
34 \\
38 \\
36 \\
34 \\
34 \\
37 \\
39 \\
33\end{array}$ \\
\hline
\end{tabular}

Scalez sand zone

\begin{tabular}{lll}
\hline $86-1 \mathrm{~B} \ldots \ldots \ldots \ldots$ & $2,694.5$ & $2,716.5$ \\
$230-16 \ldots$ &
\end{tabular}

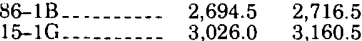

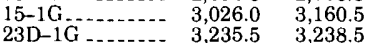

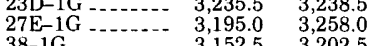

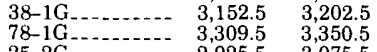

$\begin{array}{lll}25-2 \mathrm{G} \ldots \ldots \ldots-. .-2,925.5 & 3,075.5 \\ 77-2 \mathrm{G} & 2,0725 & 3,119.5\end{array}$

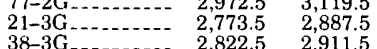

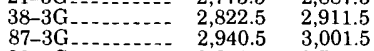

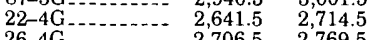

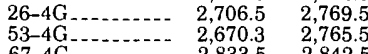

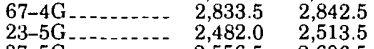

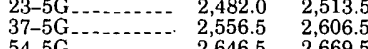

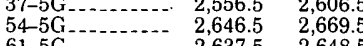

$\begin{array}{lrr}61-5 \mathrm{G} \ldots \ldots \ldots \ldots & 2,637.5 & 2,648.5 \\ 68-5 \mathrm{G} \ldots \ldots \ldots \ldots & 2,617.5 & 2,637.5 \\ 2 & \end{array}$

26-6G...-...-.-. $2,639.5 \quad 2,669.5$

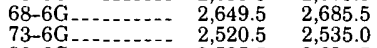

\begin{tabular}{lrr}
$88-6 \mathrm{G} \ldots \ldots \ldots \ldots-\ldots$ & $2,595.5$ & $2,624.5$ \\
$37-8 \mathrm{G} \ldots \ldots . . .-1$ & $3,334.5$ & $3,366.5$ \\
\hline
\end{tabular}

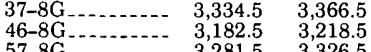

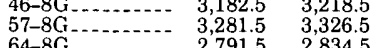

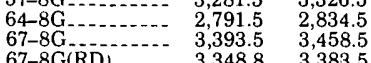

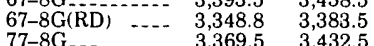

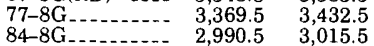

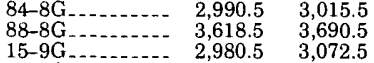

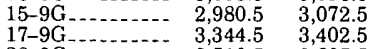

\begin{tabular}{crr}
$17-9 \mathrm{G} \ldots \ldots \ldots \ldots$ & $3,344.5$ & $3,402.5$ \\
$28-9 \mathrm{G} . . . . . . . .$. & $3,510.5$ & $33,637.5$ \\
\hline
\end{tabular}

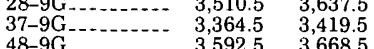

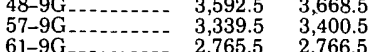

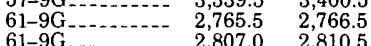

$\begin{array}{lrr}61-9 \mathrm{G} \ldots \ldots-\ldots--.- & 2,807.0 & 2,810.5 \\ 66-9 \mathrm{G} & 3262.5 & 3.324 .\end{array}$

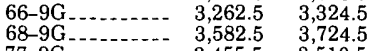

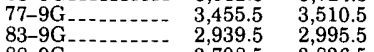

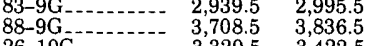

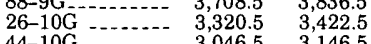

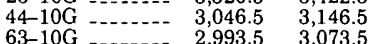

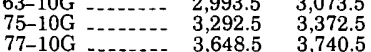

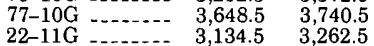

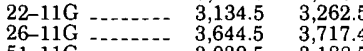

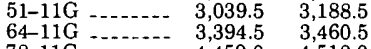

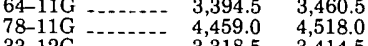

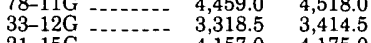

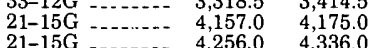

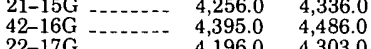

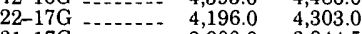

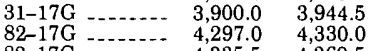

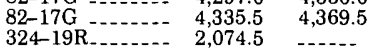

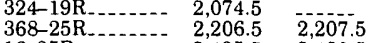

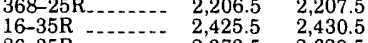

$\begin{array}{lll}\quad 86-35 \mathrm{R}-\cdots- & 2,425.5 & 2,430.5 \\ 3 & -373.5 & 2,629.5\end{array}$

$\begin{array}{lll}345-19 \mathrm{~S} \ldots \ldots- & 3,367.5 & 3,368.5 \\ 37-25 \mathrm{~S} \ldots \ldots .-1 & 3,173.5 & 3,354.5\end{array}$

\begin{tabular}{|c|c|c|c|c|}
\hline 99 & $\begin{array}{l}16- \\
431650\end{array}$ & $\begin{array}{l}327 \\
3369\end{array}$ & 27-37 27 & \\
\hline & $\begin{array}{r}4-31,650 \\
2,280-9,600\end{array}$ & $\begin{array}{r}3,369 \\
4770\end{array}$ & $21-42$ & 34 \\
\hline & & & 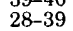 & \\
\hline & $\begin{array}{l}41-4,110 \\
15-2,020\end{array}$ & 568 & $\begin{array}{l}24-39 \\
249\end{array}$ & $\begin{array}{l}32 \\
344 \\
\end{array}$ \\
\hline & $\begin{array}{l}15-2,14,800 \\
20-1400\end{array}$ & 2,561 & $25-38$ & \\
\hline & $76-8,800$ & 2,538 & $26-41$ & \\
\hline & $\begin{array}{r}79-2,870 \\
132-2,540\end{array}$ & $\begin{array}{l}1,078 \\
1,078\end{array}$ & $\begin{array}{l}24-43 \\
26-37\end{array}$ & \\
\hline & $480-9,100$ & 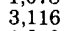 & $31-45$ & \\
\hline & $15-5,245$ & 1,61 & $25-40$ & \\
\hline & $29-8,200$ & 1,44 & $31-38$ & \\
\hline & $\begin{array}{r}21-12,000 \\
149-\quad 323\end{array}$ & $\begin{array}{l}1,608 \\
208\end{array}$ & $\begin{array}{l}21-39 \\
29-40\end{array}$ & \\
\hline & $635-6,760$ & 2,994 & $\begin{array}{l}29-40 \\
31-39\end{array}$ & \\
\hline & $29-8,800$ & 2,079 & $31-39$ & 35 \\
\hline & $\begin{array}{r}80-2,200 \\
104-1,338\end{array}$ & & $\begin{array}{l}31-39 \\
28-34\end{array}$ & \\
\hline & $\begin{array}{r}104-1,35 \\
25-3,30\end{array}$ & 610 & $\begin{array}{l}20-39 \\
32-39\end{array}$ & \\
\hline & $83-9,100$ & 2,211 & $21-40$ & \\
\hline & $\begin{array}{l}413-7,350 \\
35-750\end{array}$ & $\begin{array}{l}2,167 \\
993\end{array}$ & & \\
\hline & $154-2,920$ & $\begin{array}{r}1,096 \\
1,95\end{array}$ & 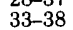 & \\
\hline & $171-2,110$ & 538 & $20-40$ & \\
\hline & $\begin{array}{l}36-3,060 \\
15-2,340\end{array}$ & $\begin{array}{l}74 \\
59\end{array}$ & $\begin{array}{l}29-37 \\
28-39\end{array}$ & \\
\hline & $47-4,545$ & 937 & & \\
\hline & $\begin{array}{l}58-4,50 \\
6-568\end{array}$ & $\begin{array}{l}1,239 \\
175\end{array}$ & & \\
\hline & $233-3,030$ & 1,055 & $30-41$ & \\
\hline & $\begin{array}{r}30-\quad 386 \\
131-\quad 3880\end{array}$ & $\begin{array}{l}185 \\
1172\end{array}$ & & \\
\hline & $4-10,900$ & $\begin{array}{l}1,172 \\
1,863\end{array}$ & & \\
\hline & $0-4,1$ & 1,141 & & \\
\hline & $\begin{aligned} 53-2,890 \\
0-8480\end{aligned}$ & 892 & $\begin{array}{l}30-39 \\
24-39 \\
24\end{array}$ & \\
\hline & $17-7,450$ & 1,090 & & \\
\hline & $132-2,395$ & 785 & & \\
\hline & $221-$ & $\begin{array}{l}280 \\
291\end{array}$ & & \\
\hline & $8-2,030$ & 270 & & \\
\hline & & $\begin{array}{l}1,752 \\
2,477\end{array}$ & & 3 \\
\hline & $21-1,820$ & $\begin{array}{l}2,415 \\
683\end{array}$ & & \\
\hline & $\begin{array}{r}0-4,230 \\
34-11200\end{array}$ & $\begin{array}{l}1,109 \\
1385\end{array}$ & $\begin{array}{l}-38 \\
-32 \\
-\end{array}$ & \\
\hline & $28-9,220$ & 1,864 & & \\
\hline & $\begin{array}{l}0-3,890 \\
0-2,690\end{array}$ & $\begin{array}{l}765 \\
727\end{array}$ & & \\
\hline & $\begin{array}{l}0-2,2800 \\
49-6,640\end{array}$ & 1,351 & & \\
\hline & $94-4,310$ & 963 & $\begin{array}{l}27-42 \\
27\end{array}$ & \\
\hline & $\begin{array}{r}0-4,470 \\
21-6,410\end{array}$ & $\begin{array}{l}1,309 \\
1,883\end{array}$ & $\begin{array}{r}8-37 \\
24-41\end{array}$ & \\
\hline & $0-4,310$ & 926 & $28-42$ & \\
\hline & & 2,558 & & \\
\hline & & 1,697 & & \\
\hline & $5-4$ & 92 & & \\
\hline & 598- & 76 & & \\
\hline & & $\begin{array}{l}1,40 \\
1,30\end{array}$ & & \\
\hline & & 250 & & \\
\hline & $11-985$ & 297 & $31-36$ & \\
\hline & $1,160-1,625$ & $\begin{array}{l}1.393 \\
1.393\end{array}$ & & \\
\hline & $\begin{array}{r}6-261 \\
127-2.250\end{array}$ & $\begin{array}{l}162 \\
857\end{array}$ & $\begin{array}{l}33-35 \\
31-38 \\
31-3\end{array}$ & \\
\hline & & 2105 & & \\
\hline
\end{tabular}


TABLE 5.-Porosity and permeability for cores from wells drilled in

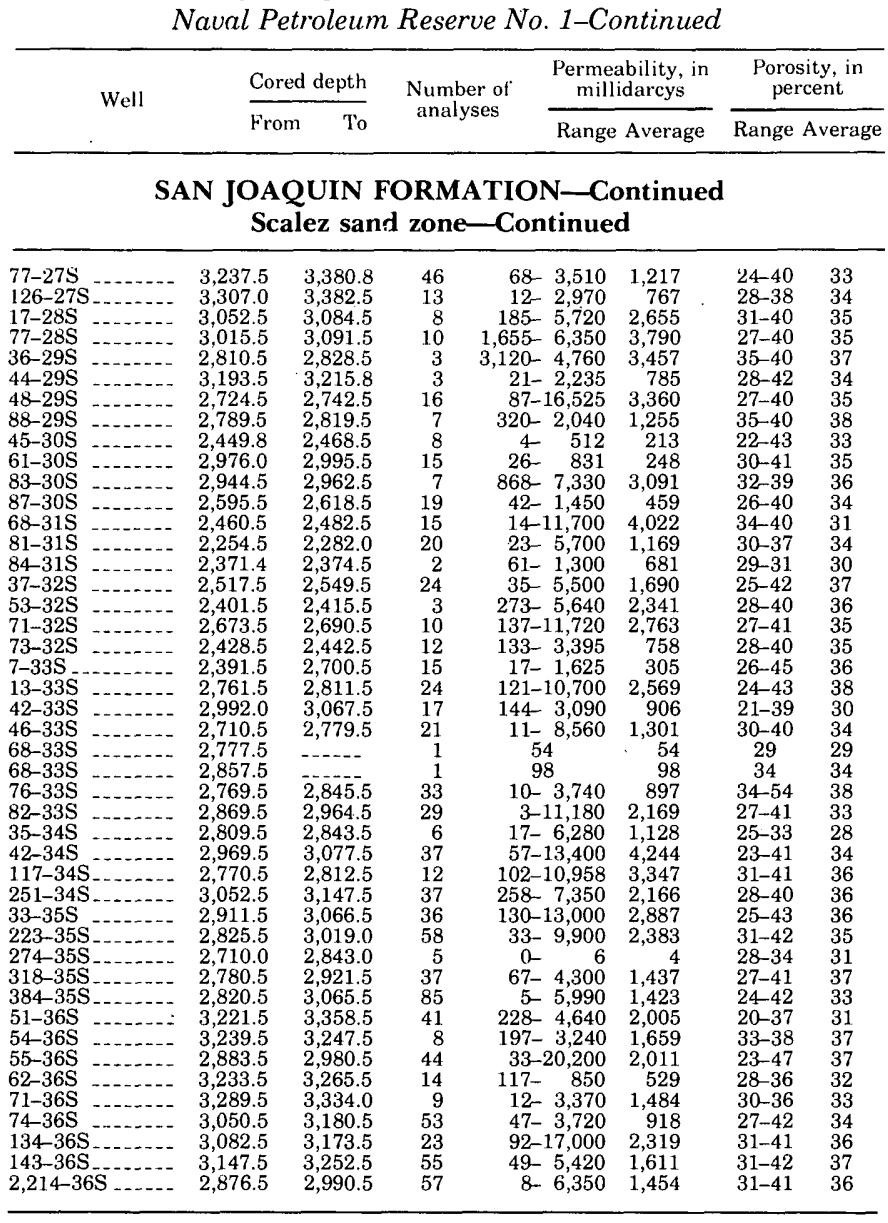

\section{ETCHEGOIN FORMATION}

\section{Mulinia sand zone}

\begin{tabular}{|c|c|c|c|c|c|}
\hline & & & & & \\
\hline & $2,621.5$ & $2,728.5$ & 20 & $0-6,600$ & \\
\hline & $\begin{array}{l}2,725.5 \\
2796.5\end{array}$ & $\begin{array}{l}2,815 \\
2,820\end{array}$ & $\begin{array}{l}15 \\
14\end{array}$ & $\begin{array}{l}18-1,400 \\
18\end{array}$ & $\begin{array}{l}268 \\
292\end{array}$ \\
\hline $\begin{array}{l}\begin{array}{l}342-3 B \\
21-3 G\end{array} \\
\text { G }\end{array}$ & $\begin{array}{l}2,796.5 \\
2,915.5\end{array}$ & $\begin{array}{l}2,820.5 \\
2,973.5\end{array}$ & $\begin{array}{l}14 \\
10\end{array}$ & $\begin{array}{ll}18- & 671 \\
71- & 775\end{array}$ & $\begin{array}{l}292 \\
334\end{array}$ \\
\hline $22-4 \mathrm{G}_{-}$ & $2,728.5$ & $2,796.5$ & 30 & & \\
\hline $26-4 G$ - & $2,801.5$ & $2,825.5$ & 13 & $160-7,200$ & \\
\hline $\begin{array}{l}53-4 G_{-} \\
55-4 G_{-}\end{array}$ & $\begin{array}{l}2,783.5 \\
2780.5\end{array}$ & $\begin{array}{l}2,81 \\
2,82\end{array}$ & $\begin{array}{l}33 \\
39\end{array}$ & $\begin{array}{r}52-22,000 \\
1-4550\end{array}$ & $\begin{array}{l}4,802 \\
1533\end{array}$ \\
\hline & $2,854.0$ & 2,88 & $\begin{array}{l}39 \\
12\end{array}$ & $\begin{array}{r}1-4,500 \\
250-3,235\end{array}$ & $\begin{array}{l}1,533 \\
1,981\end{array}$ \\
\hline & & & & & $\begin{array}{l}1,801 \\
1,802\end{array}$ \\
\hline & & & 10 & & $\begin{array}{l}1,004 \\
1,891\end{array}$ \\
\hline & $2,700.5$ & 2,71 & & 1,120 & 846 \\
\hline & $2,651.5$ & 2,74 & 26 & $-11,796$ & 1,992 \\
\hline & & & 17 & & 933 \\
\hline$-6 G_{\ldots} \ldots$ & $\begin{array}{l}2,691.5 \\
2,690\end{array}$ & $2,713.5$ & 7 & $\begin{array}{l}26-1,480 \\
64-1,40\end{array}$ & $\begin{array}{l}2,148 \\
628\end{array}$ \\
\hline$-6 c$ & $2,552.5$ & 2,55 & 3 & $18-66$ & 45 \\
\hline & & & & & 22 \\
\hline$-22 R$ & $2,564.5$ & $2,569.5$ & 3 & (140-2,790 & 986 \\
\hline${ }_{R}^{R}$ & 2,53 & 2,5 & 2 & $69-71$ & $\begin{array}{r}70 \\
712\end{array}$ \\
\hline & & 2,72 & 4 & $\begin{array}{l}740-2,970 \\
159-2320\end{array}$ & $\begin{array}{l}1,713 \\
1,85\end{array}$ \\
\hline$-23 \pi$ & 2,56 & $\begin{array}{l}2,5 \\
2,5 \varepsilon\end{array}$ & 8 & $\begin{array}{r}159-2,320 \\
44-1,820\end{array}$ & $\begin{array}{l}1,185 \\
331\end{array}$ \\
\hline$-24 R$ & $3,037.2$ & 3,05 & 10 & $45-2,190$ & \\
\hline 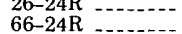 & $\begin{array}{l}2,60 \\
2,82\end{array}$ & $\begin{array}{l}2,63 \\
2,85 \\
2\end{array}$ & & $\begin{array}{l}0-2,800 \\
9-2360\end{array}$ & $\begin{array}{l}648 \\
478\end{array}$ \\
\hline $86-24 \mathrm{R}$ & 年, $2,936.5$ & $2,965.5$ & 12 & $18-1,830$ & 363 \\
\hline $3 \mathrm{~A}-26 \mathrm{R}$ & $\begin{array}{l}2,263.5 \\
2,665.5 \\
\end{array}$ & $\begin{array}{l}2,41 \\
2,71\end{array}$ & & $\begin{array}{r}5-1,115 \\
746-5,280\end{array}$ & $\begin{array}{r}200 \\
2584\end{array}$ \\
\hline ........... & $\begin{array}{l}2,656.5 \\
2,324.5\end{array}$ & $\begin{array}{l}2,15.5 \\
2,358.5\end{array}$ & $\begin{array}{r}6 \\
23\end{array}$ & $\begin{array}{r}746-5,280 \\
35-2,560\end{array}$ & $\begin{array}{l}2,584 \\
439 \\
\quad\end{array}$ \\
\hline 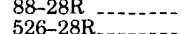 & $2,482.5$ & & 8 & $62-1,150$ & 461 \\
\hline & & & & & $\begin{array}{l}16 \\
80\end{array}$ \\
\hline & 2,74 & $2,747.0$ & 2 & 132 & 144 \\
\hline & & & $1_{1}^{2}$ & & 294 \\
\hline & & & 9 & & $\begin{array}{c}27 \\
67\end{array}$ \\
\hline ...... & 2,570 & 2,5 & 3 & $15-1,540$ & 858 \\
\hline & & & & & 28 \\
\hline & & & & .180 & \\
\hline & & $2,549.5$ & & $138-693$ & \\
\hline
\end{tabular}

TABLE 5.-Porosity and permeability for cores from wells drilled in Naval Petroleum Reserve No. 1-Continued

\begin{tabular}{|c|c|c|c|c|c|c|c|c|}
\hline \multirow{2}{*}{ Well } & \multicolumn{2}{|c|}{ Cored depth } & \multirow{2}{*}{\multicolumn{2}{|c|}{$\begin{array}{l}\text { Number of } \\
\text { analyses }\end{array}$}} & \multirow{2}{*}{\multicolumn{2}{|c|}{$\frac{\begin{array}{c}\text { Permeability, in } \\
\text { millidarcys }\end{array}}{\text { Range Average }}$}} & \multicolumn{2}{|c|}{$\begin{array}{l}\text { Porosity, in } \\
\text { percent }\end{array}$} \\
\hline & \multicolumn{2}{|c|}{ From } & & & & & Range & verage \\
\hline \multicolumn{9}{|c|}{$\begin{array}{c}\text { ETCHEGOIN FORMATION-Continued } \\
\text { Mulinia sand zone-Continued }\end{array}$} \\
\hline $16-35 R$ & $2,484.5$ & $2,620.5$ & 24 & $4-$ & 439 & 151 & $27-38$ & 33 \\
\hline $86-35 \mathrm{R}$ & $2,685.5$ & $2,724.5$ & 18 & 5 & $530^{\circ}$ & 119 & $27-34$ & 30 \\
\hline $38-35 R$ & $2,873.5$ & $2,895.5$ & 5 & 32 & 510 & 436 & $31-34$ & 33 \\
\hline$-36 \mathrm{R}$ & $2,603.5$ & $2,692.5$ & 6 & $27-$ & 872 & 291 & $30-40$ & 33 \\
\hline $248-36 \mathrm{R}$ & $2,855.5$ & $2,897.5$ & 16 & 2 & 1,300 & 89 & $25-32$ & 30 \\
\hline $345-19 \mathrm{~S}$ & $3,367.5$ & $3,368.5$ & 2 & $2 \overline{1}-$ & 4,075 & 2,048 & $19-44$ & 31 \\
\hline $37-25 \mathrm{~S}$ & $3,376.5$ & $3,475.5$ & 18 & $3-$ & 1,330 & 194 & $26-41$ & 34 \\
\hline $17-27 \mathrm{~S}$ & $3,366.5$ & $3,428.5$ & 20 & 122 & 3,730 & 1,557 & $21-42$ & 35 \\
\hline $77-27 \mathrm{~S}$ & $3,382.5$ & $3,465.5$ & 22 & 4 & 1,565 & 421 & $22-38$ & 30 \\
\hline $126-27 \mathrm{~S}$ & $3,414.5$ & $\begin{array}{l}3,511.5 \\
3,400.0\end{array}$ & 29 & $138-1$ & 10,700 & 3,336 & $26-41$ & 34 \\
\hline $248-27 \mathrm{~S}$ & $3,220.5$ & $3,287.5$ & 23 & $304-$ & 8,530 & 2,734 & $31-40$ & 36 \\
\hline $17-28 \mathrm{~S}$ & $3,092.5$ & $3,201.0$ & 24 & $290-$ & 4,130 & 1,841 & $26-41$ & 36 \\
\hline $77-28 \mathrm{~S}$ & $3,136.5$ & $3,202.5$ & 13 & $66-$ & 4,920 & 1,553 & $27-43$ & 31 \\
\hline $36-29 \mathrm{~S}$ & $2,916.5$ & $2,926.5$ & 4 & 0 & 530 & 158 & $32-37$ & 34 \\
\hline $44-29 S$ & $3,227.5$ & $3,238.7$ & 2 & $135-$ & 318 & 227 & $22-42$ & 32 \\
\hline $48-29 \mathrm{~S}$ & $2,765.0$ & $2,787.5$ & $1 \overline{1}$ & 236 & 1,530 & 878 & $24-40$ & 32 \\
\hline $88-29 S$ & $2,820.5$ & $2,854.5$ & 4 & $156-$ & 1,540 & 747 & $32-39$ & 36 \\
\hline $43-30 \mathrm{~S}$ & $2,740.5$ & $2,771.5$ & 12 & 0 & 35 & 19 & $12-39$ & 35 \\
\hline $61-30 \mathrm{~S}$ & $3,094.5$ & $3,214.5$ & 5 & $8-$ & 126 & 71 & $26-34$ & 32 \\
\hline $87-30 \mathrm{~S}$ & $2,621.5$ & $2,629.5$ & 7 & $28-$ & 5,060 & 867 & $32-38$ & 35 \\
\hline $68-31 \mathrm{~S}$ & $2,492.5$ & $2,549.5$ & 5 & $50-$ & 1,434 & 379 & $34-37$ & 35 \\
\hline $84-31 S$ & $2,392.5$ & $2,420.5$ & 6 & $30-$ & 8,600 & 2,688 & $24-38$ & 33 \\
\hline $37-32 \mathrm{~S}$ & $2,550.5$ & $2,620.5$ & 16 & 0 & 728 & 167 & $27-38$ & 33 \\
\hline $53-32 S$ & $2,425.5$ & $2,489.5$ & 5 & 217 & 1,190 & 556 & $32-43$ & 38 \\
\hline $71-32 \mathrm{~S}$ & $2,719.5$ & $2,807.5$ & 14 & $287-2$ & 21,900 & 3,407 & $31-41$ & 36 \\
\hline $73-32 \mathrm{~S}$ & $2,453.0$ & $2,554.5$ & 20 & $30-$ & 5,750 & 1,642 & $33-42$ & 37 \\
\hline $7-33 \mathrm{~S}$ & $2,711.0$ & $2,966.5$ & 13 & 7 & 1,651 & 306 & $20-46$ & 36 \\
\hline $13-33 \mathrm{~S}$ & $2,820.5$ & $2,903.5$ & 20 & $93-1$ & 14,600 & 2,565 & $28-41$ & 30 \\
\hline $42-33 \mathrm{~S}$ & $3,086.0$ & $3,121.5$ & 9 & 120 & 1,600 & $\begin{array}{l}621 \\
621\end{array}$ & $27-43$ & 40 \\
\hline $46-33 \mathrm{~S}$ & $2,793.5$ & $2,885.5$ & 16 & 300 & 4,400 & 1,520 & $26-39$ & 33 \\
\hline $68-33 \mathrm{~S}$ & $2,930.5$ & $2,973.5$ & 7 & $71-$ & 3,640 & 953 & $29-41$ & 37 \\
\hline $76-33 S$ & $2,887.5$ & $3,127.5$ & 31 & 38 & 8,000 & 1,907 & $31-47$ & 39 \\
\hline $82-33 \mathrm{~S}$ & $2,983.5$ & $3,082.5$ & $5 i ̀$ & $57-1$ & 13,800 & 2,795 & $27-42$ & 34 \\
\hline $42-34 \mathrm{~S}$ & $3,103.5$ & $3,173.5$ & 28 & $88-2$ & 22,340 & 3,947 & $28-42$ & 35 \\
\hline $117-34 \mathrm{~S}$ & $2,862.5$ & $2,887.5$ & 11 & $138-$ & 3,420 & 1,130 & $28-40$ & 35 \\
\hline $251-3$ & $3,173.5$ & $3,251.5$ & 17 & $121-$ & 1,120 & 507 & $30-37$ & 34 \\
\hline $\begin{array}{l}33-35 \mathrm{~S} \\
33\end{array}$ & $3,098.5$ & $3,152.5$ & 6 & 42 & 2,300 & 1,888 & $26-35$ & 32 \\
\hline $223-35 \mathrm{~S}$ & $3,034.0$ & $3,085.5$ & 4 & 0 & 101 & 28 & $26-33$ & 30 \\
\hline $228-35 \mathrm{~S}$ & $3,054.5$ & $3,069.5$ & 5 & $6-$ & 325 & 139 & $27-38$ & 33 \\
\hline $318-35 \mathrm{~S}$ & $2,944.5$ & $2,958.5$ & 2 & $48-$ & 67 & 58 & $35-37$ & 36 \\
\hline $384-35 \mathrm{~S}$ & $3,074.5$ & $3,129.5$ & 12 & 0 & 5,500 & 916 & $10-35$ & 30 \\
\hline $143-36 \mathrm{~S}$ & $3,272.5$ & $3,339.5$ & 6 & $30-$ & 1,230 & 605 & $29-37$ & 33 \\
\hline $326-24 Z_{\ldots}$ & $2,828.5$ & $2,921.5$ & 4 & $16-$ & 229 & 83 & $30-35$ & 33 \\
\hline
\end{tabular}

\begin{tabular}{|c|c|c|c|c|c|c|c|}
\hline \multicolumn{8}{|c|}{ Wilhelm sand zone } \\
\hline $22-1 \mathrm{~B}$ & $2,975.5$ & $2,980.2$ & 6 & $10-$ & 36 & $26-31$ & 29 \\
\hline $242-1 \mathrm{~B}$ & $3,002.5$ & $3,056.5$ & 50 & 545 & 143 & $28-38$ & 34 \\
\hline $242-1 \mathrm{~B}$ & $3,162.5$ & $3,179.5$ & 17 & 52 & 18 & $31-39$ & 37 \\
\hline $324-19 \mathrm{R}$ & $2,281.5$ & $2,536.5$ & 13 & 836 & 161 & $29-37$ & 35 \\
\hline $86-22 \mathrm{R}-$ & $2,796.5$ & $3,000.5$ & 77 & 107 & 28 & $19-33$ & 29 \\
\hline $368-25 R_{-}$ & $2,516.5$ & $2,519.5$ & 4 & 113 & 65 & $27-34$ & 30 \\
\hline $382-26 \mathrm{R}$ & $2,584.5$ & $2,654.5$ & 12 & $29-115$ & .68 & $22-31$ & 27 \\
\hline $28-27 \mathrm{R}^{-}$ & $2,573.5$ & $2,717.5$ & 99 & $0-1,435$ & 70 & $28-40$ & 35 \\
\hline $46-27 \mathrm{R}$ & $2,676.5$ & $2,723.5$ & 15 & $28-\quad 266$ & 94 & $22-34$ & 30 \\
\hline $24-28 \mathrm{R}$ & $2,470.5$ & $2,534.5$ & 57 & 190 & 35 & $30-39$ & 36 \\
\hline $68-28 \mathrm{R}$ & $2,550.5$ & $2,609.5$ & 56 & $0-\quad 790$ & 78 & $29-39$ & 34 \\
\hline $88-28 \mathrm{R}$. & $2,550.5$ & $2,645.5$ & 96 & $0-1,230$ & 105 & $30-39$ & 35 \\
\hline $526-28 \mathrm{R}-$ & $2,417.5$ & $2,648.5$ & 42 & $0-\quad 740$ & 104 & 23-39 & 33 \\
\hline $24-29 \mathrm{R}-$ & $2,490.5$ & $2,679.5$ & 133 & $2-1,900$ & 109 & $23-38$ & 33 \\
\hline $26-29 \mathrm{R}$ & $2,764.5$ & $2,957.5$ & 32 & $0-\quad 461$ & 88 & $27-38$ & 31 \\
\hline $46-29 \mathrm{R}$ & $2,700.5$ & $2,744.5$ & 34 & $2-\quad 323$ & 33 & $29-36$ & 33 \\
\hline $84-29 R$ & $2,460.5$ & $2,614.5$ & 143 & $1-1,560$ & 68 & & 36 \\
\hline $86-29 \mathrm{R}$ & $2,385.5$ & $2,515.5$ & 103 & $3-1,090$ & 46 & $27-39$ & 35 \\
\hline $326-29 R$ & $3,068.0$ & & 1 & 90 & 90 & & 40 \\
\hline $61-32 \mathrm{R}$. & $2,841.5$ & $3,237.5$ & 105 & 0 & 15 & $21-39$ & 29 \\
\hline 42-33R & $2,568.5$ & $2,819.5$ & 88 & $3-\quad 147$ & 37 & $25-44$ & 23 \\
\hline $24-34 \mathrm{R}$ & $2,582.5$ & 2,90 & 119 & $3-1,060$ & 76 & $24-38$ & 29 \\
\hline $26-34 \mathrm{R}$ & $2,715.5$ & $2,873.5$ & 92 & & 39 & & 33 \\
\hline $42-34 \mathrm{R}$ & $2,650.5$ & $2,719.5$ & 69 & $3-2,300$ & 176 & $30-39$ & 36 \\
\hline $58-34 \mathrm{R}$ & $2,758.5$ & $3,100.5$ & 134 & $0-\quad 261$ & 41 & $22-35$ & 30 \\
\hline $16-35 \mathrm{R}$ & $2,709.5$ & $3,021.5$ & 60 & $1-\quad 123$ & 24 & $24-39$ & 36 \\
\hline $22-35 \mathrm{R}$ & $2,790.5$ & 2,94 & 55 & 4- 1,820 & 220 & $17-36$ & 31 \\
\hline $86-35 \mathrm{R}$ & $2,946.5$ & $3,154,0$ & 59 & $0-\quad 345$ & 74 & & 31 \\
\hline $24-36 \mathrm{R}$ & $2,760.5$ & $2,938.5$ & 62 & $0-\quad 407$ & 37 & $19-$ & 30 \\
\hline $248-36 \mathrm{R}-$ & $2,898.5$ & $2,962.5$ & 52 & $2-540$ & 83 & $25-37$ & 33 \\
\hline $37-25 \mathrm{~S} \ldots$ & $3,697.5$ & $3,781.5$ & 21 & $2-3,050$ & 445 & $26-35$ & 31 \\
\hline $223-35 \mathrm{~S}$ & $3,369.5$ & $3,426.5$ & 14 & $0-91$ & 34 & $26-38$ & 31 \\
\hline$-23 Z^{-}$ & $2,910.5$ & $3,049.5$ & 81 & 160 & 19 & $23-35$ & 30 \\
\hline $326-24 Z$ & $2,983.5$ & $3,104.5$ & 83 & $5-\quad 63$ & 19 & $23-34$ & 29 \\
\hline
\end{tabular}

Gusher sand zone

\begin{tabular}{|c|c|c|c|c|c|c|c|c|}
\hline $\begin{array}{l}324-19 R \\
326-29 R \\
326-29 R \\
61-32 R \\
42-33 R \\
24-34 R \\
58-34 R \\
16-35 R\end{array}$ & $\begin{array}{l}2,584.0 \\
3,475.0 \\
3,146.0 \\
3,238.5 \\
3,029.5 \\
3,070.5 \\
3,164.2 \\
3,126.5\end{array}$ & \begin{tabular}{l}
$2,897.8$ \\
\hdashline..-- \\
$3,481.5$ \\
$3,167.5$ \\
$3,344.5$ \\
$3,239.5$ \\
$3,503.5$
\end{tabular} & $\begin{array}{r}21 \\
1 \\
1 \\
13 \\
33 \\
12 \\
13 \\
5 \\
29\end{array}$ & $\begin{array}{l}3- \\
37 \\
15 \\
0- \\
5- \\
8- \\
0- \\
0-\end{array}$ & $\begin{array}{r}373 \\
61 \\
72 \\
26 \\
63\end{array}$ & $\begin{array}{r}50 \\
37 \\
15 \\
74 \\
23 \\
30 \\
5 \\
16\end{array}$ & $\begin{array}{c}27-37 \\
35 \\
47 \\
20-34 \\
28-40 \\
20-33 \\
26-29 \\
24-37\end{array}$ & $\begin{array}{l}33 \\
35 \\
47 \\
28 \\
33 \\
28 \\
28 \\
33\end{array}$ \\
\hline
\end{tabular}


TABLE 5.-Porosity and permeability for cores from wells drilled in Naval Petroleum Reserve No. 1-Continued

\begin{tabular}{|c|c|c|c|c|c|c|c|}
\hline \multirow{2}{*}{ Well } & \multicolumn{2}{|c|}{ Cored depth } & \multirow{2}{*}{$\begin{array}{l}\text { Number of } \\
\text { analyses }\end{array}$} & \multirow{2}{*}{\multicolumn{2}{|c|}{$\frac{\begin{array}{c}\text { Permeability, in } \\
\text { millidarcys }\end{array}}{\text { Range Average }}$}} & \multirow{2}{*}{\multicolumn{2}{|c|}{$\frac{\begin{array}{c}\text { Porosity, in } \\
\text { percent }\end{array}}{\text { Range Averag }}$}} \\
\hline & \multicolumn{2}{|c|}{ From } & & & & & \\
\hline \multicolumn{6}{|c|}{$\begin{array}{c}\text { ETCHEGOIN FORMATION-Continued } \\
\text { Gusher sand zone-Continued }\end{array}$} & \multicolumn{2}{|l|}{ 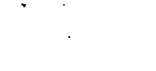 } \\
\hline \multirow[t]{2}{*}{$\begin{array}{l}22-36 R \\
37-25 \mathrm{~S} \\
223-35 \mathrm{~S} \\
326-\ldots . \\
326-35\end{array}$} & $\begin{array}{l}3,120.5 \\
4,033.5 \\
3,820.5 \\
3,767.0\end{array}$ & $\begin{array}{l}3,646.5 \\
4,172.5 \\
4,133.0 \\
3.813 .0\end{array}$ & $\begin{array}{r}164 \\
17 \\
12 \\
9\end{array}$ & $\begin{array}{lr}0- & 153 \\
3- & 2,730 \\
5- & 4,920 \\
3- & 40\end{array}$ & $\begin{array}{r}14 \\
616 \\
1,389 \\
16\end{array}$ & $\begin{array}{l}27-39 \\
28-33 \\
30-38 \\
28-36\end{array}$ & $\begin{array}{l}33 \\
30 \\
33 \\
30\end{array}$ \\
\hline & \multicolumn{5}{|c|}{ Calitroleum sand zone } & \\
\hline $\begin{array}{l}324-19 R \ldots . . \\
22-36 R\end{array}$ & $\begin{array}{l}3,246.5 \\
3,689.5\end{array}$ & $\begin{array}{l}3,386.0 \\
4,063.5\end{array}$ & $\begin{array}{r}11 \\
108\end{array}$ & $\begin{array}{lr}0- & 41 \\
0- & 140\end{array}$ & $\begin{array}{l}17 \\
17\end{array}$ & $\begin{array}{l}29-35 \\
25-38\end{array}$ & $\begin{array}{l}32 \\
32\end{array}$ \\
\hline \multicolumn{8}{|c|}{ Buliminella silt zone } \\
\hline $\begin{array}{l}324-19 R \\
324-19 R-\ldots\end{array}$ & $\begin{array}{l}4,018.0 \\
4,060.0\end{array}$ & $\begin{array}{l}4,052.5 \\
4,711.0\end{array}$ & $\begin{array}{l}14 \\
60\end{array}$ & ${ }^{0}$ (all wells & $s=01$ & $\begin{array}{l}24-32 \\
-\cdots\end{array}$ & 28 \\
\hline \multicolumn{8}{|c|}{ Olig sand zone } \\
\hline $\begin{array}{l}37-30 \mathrm{R} \\
364-30 \mathrm{R} \\
382-26 \mathrm{Z}\end{array}$ & $\begin{array}{l}5,237.5 \\
4,938.5 \\
4,840.5\end{array}$ & $\begin{array}{l}5,301.5 \\
4,950.5 \\
4,915.5\end{array}$ & $\begin{array}{r}60 \\
8 \\
56\end{array}$ & $\begin{array}{lr}0- & 730 \\
0- & 63 \\
0- & 71\end{array}$ & $\begin{array}{r}103 \\
14 \\
3\end{array}$ & $\begin{array}{r}15-27 \\
17-25 \\
8-30\end{array}$ & $\begin{array}{l}22 \\
20 \\
21\end{array}$ \\
\hline \multicolumn{8}{|c|}{ REEF RIDGE SHALE } \\
\hline 324-19R. & $4,720.0$ & $4,862.0$ & 13 & (all wells & $s=0)$ & $-\cdots$ & .... \\
\hline \multicolumn{8}{|c|}{$\begin{array}{l}\text { MONTEREY SHALE AND STEVENS OIL ZONE } \\
\text { N zone }\end{array}$} \\
\hline $\begin{array}{l}358-22 R \\
378-22 R \\
\end{array}$ & $\begin{array}{l}7,280.0 \\
6,869.5\end{array}$ & $\begin{array}{l}7,284.0 \\
6,870.5\end{array}$ & $\begin{array}{l}4 \\
2\end{array}$ & $4_{0}$ & $\begin{array}{l}11 \\
.3\end{array}$ & $\begin{array}{c}15-20 \\
14\end{array}$ & $\begin{array}{l}17 \\
14\end{array}$ \\
\hline \multicolumn{8}{|c|}{ A zone } \\
\hline $\begin{array}{l}342-3 G \\
362-3 G \\
382-3 G \\
343-4 G \\
382-4 G \\
378- \\
378-22 R \\
322-25 R \\
312-26 R \\
344-26 R \\
526-28 R \\
344-30 \mathrm{R} \\
542-31 \mathrm{~S} \\
366-32 \mathrm{~S} \\
388-32 \mathrm{~S} \\
386-33 \mathrm{~S} \\
337-34 \mathrm{~S} \\
344-34 \mathrm{~S} \\
326-35 \mathrm{~S} \\
344-35 \mathrm{~S} \\
384-35 \mathrm{~S} \\
17-14 \mathrm{Z} \\
\end{array}$ & $\begin{array}{l}7,015.5 \\
6,968.5 \\
7,019.5 \\
6,508.5 \\
6,739.5 \\
6,883.5 \\
5,400.5 \\
6,434.5 \\
6,002.5 \\
5,152.0 \\
7,348.5 \\
5,018.5 \\
5,595.5 \\
6,120.5 \\
6,809.5 \\
6,626.5 \\
7,008.5 \\
6,649.5 \\
6,854.5 \\
7,104.5 \\
4,961.0\end{array}$ & $\begin{array}{l}7,051.5 \\
7,043.5 \\
7,062.5 \\
6,703.5 \\
6,778.5 \\
7,227.5 \\
5,588.0 \\
6,437.5 \\
6,151.5 \\
5,169.0 \\
7,478.5 \\
5,040.5 \\
5,761.5 \\
6,197.5 \\
6,842.5 \\
6,627.5 \\
7,059.5 \\
6,701.5 \\
6,870.5 \\
7,124.5 \\
4,979.0\end{array}$ & $\begin{array}{r}8 \\
16 \\
20 \\
9 \\
16 \\
50 \\
19 \\
3 \\
10 \\
5 \\
14 \\
5 \\
33 \\
7 \\
13 \\
2 \\
17 \\
19 \\
8 \\
7 \\
8\end{array}$ & $\begin{array}{lr}0- & 73 \\
0- & 36 \\
0- & 6 \\
0- & 4 \\
0- & 11 \\
0- & 305 \\
0- & 10 \\
1- & 299 \\
0- & 187 \\
0- & 6 \\
0- & 5 \\
0- & 5 \\
0- & 71 \\
0- & 2 \\
0- & 22 \\
0- & 1 \\
0- & 15 \\
0- & 46 \\
6- & 248 \\
0- & 45 \\
0- & 11\end{array}$ & $\begin{array}{c}22 \\
11 \\
1 \\
.6 \\
3 \\
19 \\
2 \\
138 \\
52 \\
2 \\
1 \\
2 \\
14 \\
.04 \\
8 \\
.035 \\
3 \\
6 \\
59 \\
12 \\
2\end{array}$ & $\begin{array}{r}14-25 \\
12-29 \\
12-19 \\
11-20 \\
8-21 \\
12-26 \\
8-23 \\
14-23 \\
13-26 \\
18-25 \\
9-21 \\
7-30 \\
10-23 \\
16-19 \\
10-23 \\
13-19 \\
13-20 \\
11-22 \\
13-26 \\
16-21 \\
19-29\end{array}$ & $\begin{array}{l}20 \\
20 \\
15 \\
16 \\
15 \\
17 \\
16 \\
20 \\
19 \\
23 \\
14 \\
23 \\
14 \\
18 \\
18 \\
16 \\
17 \\
17 \\
17 \\
19 \\
24\end{array}$ \\
\hline \multicolumn{8}{|c|}{$\begin{array}{l}\text { MONTEREY SHALE } \\
\text { 26R sand }\end{array}$} \\
\hline 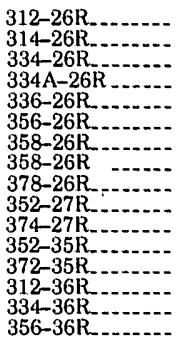 & $\begin{array}{l}6,499.5 \\
6,400.5 \\
5,893.5 \\
6,296.5 \\
6,063.5 \\
5,600.5 \\
6,129.5 \\
6,923.5 \\
5,812.5 \\
6,887.5 \\
6,822.5 \\
7,086.5 \\
6,384.5 \\
5,895.5 \\
6,333.5 \\
6,764.5\end{array}$ & $\begin{array}{l}6,626.5 \\
7,242.5 \\
6,175.5 \\
6,818.5 \\
7,488.5 \\
6,043.5 \\
6,521.5 \\
7,019.5 \\
6,466.5 \\
7,419.5 \\
7,409.5 \\
7,456.5 \\
7,145.5 \\
6,989.5 \\
7,421.5 \\
7,058.5\end{array}$ & $\begin{array}{r}33 \\
387 \\
192 \\
56 \\
659 \\
178 \\
180 \\
15 \\
400 \\
328 \\
326 \\
177 \\
349 \\
723 \\
626 \\
27\end{array}$ & $\begin{array}{rr}2- & 214 \\
9- & 2,140 \\
0- & 1,290 \\
0- & 560 \\
0- & 1,580 \\
15- & 1,290 \\
0- & 2,470 \\
2- & 1,000 \\
0- & 1,440 \\
0- & 1,010 \\
0- & 3,880 \\
0- & 980 \\
0- & 874 \\
0- & 1,520 \\
0- & 5,440 \\
0- & 370\end{array}$ & $\begin{array}{r}65 \\
651 \\
344 \\
114 \\
269 \\
356 \\
346 \\
164 \\
213 \\
184 \\
318 \\
38 \\
85 \\
198 \\
181 \\
49\end{array}$ & $\begin{array}{r}13-30 \\
16-37 \\
16-36 \\
8-34 \\
11-38 \\
14-34 \\
11-36 \\
16-30 \\
9-35 \\
6-29 \\
7-32 \\
8-27 \\
6-33 \\
7-35 \\
9-33 \\
13-25\end{array}$ & $\begin{array}{l}22 \\
29 \\
27 \\
25 \\
26 \\
25 \\
27 \\
23 \\
24 \\
21 \\
22 \\
18 \\
23 \\
24 \\
22 \\
19\end{array}$ \\
\hline
\end{tabular}

$24 \mathrm{Z}$ (Asphalto) sand zone

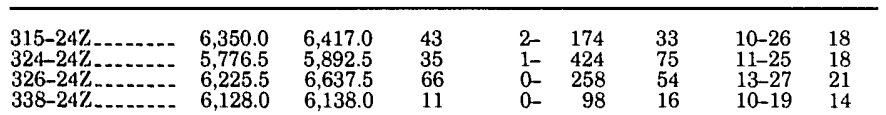

TABLE 5. Porosity and permeability for cores from wells drilled in Naval Petroleum Reserve No. 1-Continued

\begin{tabular}{|c|c|c|c|c|c|}
\hline \multirow{2}{*}{ Well } & \multicolumn{2}{|c|}{ Cored depth } & \multirow{2}{*}{$\begin{array}{l}\text { Number of } \\
\text { analyses }\end{array}$} & \multirow{2}{*}{$\begin{array}{c}\begin{array}{c}\text { Permeability, in } \\
\text { millidarcys }\end{array} \\
\text { Range Average }\end{array}$} & \multirow{2}{*}{$\begin{array}{c}\begin{array}{c}\text { Porosity, in } \\
\text { percent }\end{array} \\
\text { Range Average }\end{array}$} \\
\hline & From & To & & & \\
\hline \multicolumn{6}{|c|}{$\begin{array}{l}\text { MONTEREY SHALE-Continued } \\
24 Z \text { (Asphalto) sand zone-Continued }\end{array}$} \\
\hline
\end{tabular}

\begin{tabular}{|c|c|c|c|c|c|c|c|}
\hline $\begin{array}{l}341-24 Z \\
344-24 Z \\
344-24 Z \\
344-24 Z \\
346-24 Z \\
348 X-24 Z \\
348 X R-24 Z \\
358 X R-24 Z \\
363-24 Z \\
366-24 Z \\
383-24 Z \\
385-24 Z \\
352-26 Z \\
372-26 Z \\
382-26 Z \\
383-26 Z \\
391 X-26 Z \\
\end{array}$ & $\begin{array}{l}5,334.3 \\
4,998.5 \\
5,270.5 \\
5,562.5 \\
5,948.5 \\
6,154.5 \\
6,197.5 \\
6,295.5 \\
4,850.5 \\
5,748.5 \\
5,895.5 \\
5,142.5 \\
5,669.5 \\
5,615.0 \\
5,580.5 \\
5,435.5 \\
5,732.5\end{array}$ & $\begin{array}{l}5,782.5 \\
5,106.5 \\
5,469.5 \\
5,701.5 \\
6,467.5 \\
6,246.5 \\
6,247.5 \\
6,314.5 \\
5,205.5 \\
6,366.5 \\
6,402.5 \\
5,219.5 \\
5,998.5 \\
5,950.0 \\
5,880.5 \\
5,546.5 \\
5,814.5\end{array}$ & $\begin{array}{r}204 \\
45 \\
57 \\
81 \\
274 \\
67 \\
35 \\
20 \\
110 \\
454 \\
171 \\
51 \\
158 \\
11 \\
260 \\
86 \\
51\end{array}$ & $\begin{array}{rr}0- & 2,290 \\
0- & 1,430 \\
1- & 1,120 \\
0- & 277 \\
0- & 1,378 \\
0- & 1,322 \\
0- & 4,950 \\
0- & 352 \\
0- & 2,460 \\
0- & 4,120 \\
0- & 938 \\
0- & 287 \\
2- & 7,420 \\
13- & 558 \\
0- & 1,550 \\
0- & 663 \\
0- & 610\end{array}$ & $\begin{array}{r}278 \\
258 \\
289 \\
43 \\
130 \\
102 \\
419 \\
52 \\
435 \\
198 \\
57 \\
111 \\
437 \\
183 \\
159 \\
86 \\
83\end{array}$ & $\begin{array}{r}5-33 \\
18-33 \\
10-35 \\
3-26 \\
11-34 \\
10-27 \\
10-33 \\
8-23 \\
3-34 \\
5-36 \\
8-29 \\
16-29 \\
9-43 \\
27-34 \\
3-29 \\
10-29 \\
7-29\end{array}$ & $\begin{array}{l}23 \\
32 \\
23 \\
17 \\
24 \\
21 \\
21 \\
18 \\
22 \\
23 \\
22 \\
22 \\
24 \\
30 \\
21 \\
21 \\
18\end{array}$ \\
\hline
\end{tabular}

\begin{tabular}{|c|c|c|c|c|c|c|c|}
\hline & & & B zo & & & & \\
\hline 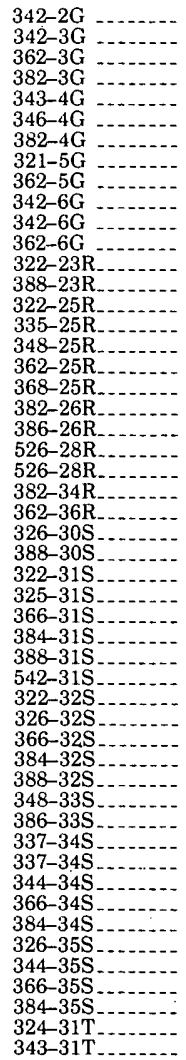 & $\begin{array}{l}7,275.5 \\
7,056.5 \\
7,046.5 \\
7,109.5 \\
6,770.5 \\
7,250.5 \\
6,945.5 \\
6,000.5 \\
6,479.5 \\
7,232.5 \\
7,334.5 \\
7,022.5 \\
8,886.5 \\
6,153.5 \\
5,610.5 \\
5,380.5 \\
5,505.5 \\
6,041.5 \\
5,210.0 \\
5,533.5 \\
5,946.5 \\
5,357.5 \\
5,432.5 \\
8,141.5 \\
5,471.5 \\
5,706.5 \\
6,406.5 \\
5,208.5 \\
5,626.5 \\
5,446.5 \\
5,390.5 \\
6,100.5 \\
5,200.2 \\
6,041.5 \\
5,511.5 \\
5,762.5 \\
6,363.5 \\
6,37.5 \\
6,575.5 \\
6,845.5 \\
6,790.0 \\
6,860.5 \\
7,060.5 \\
6,678.5 \\
6,858.5 \\
6,711.5 \\
6,900.5 \\
6,944.5 \\
7,255.5 \\
8,489.5 \\
8,648.5\end{array}$ & $\begin{array}{l}8,298.5 \\
5,808.5 \\
6,002.5 \\
6,641.5 \\
5,455.5 \\
5,800.5 \\
5,706.5 \\
5,749.5 \\
6,535.5 \\
5,340.5 \\
6,288.5 \\
5,747.5 \\
6,155.5 \\
6,786.5 \\
6,576.5 \\
6,960.5 \\
7,314.5 \\
6,791.0 \\
7,209.5 \\
7,301.5 \\
7,162.5 \\
7,282.5 \\
7,282.3 \\
7,447.5 \\
7,533.5 \\
7,677.5 \\
9,008.5 \\
8,748.0\end{array}$ & $\begin{array}{r}415 \\
413 \\
38 \\
402 \\
247 \\
121 \\
355 \\
178 \\
145 \\
2 \\
3 \\
3 \\
28 \\
120 \\
63 \\
75 \\
60 \\
70 \\
6 \\
115 \\
56 \\
1 \\
1 \\
18 \\
65 \\
63 \\
4 \\
70 \\
50 \\
103 \\
46 \\
79 \\
33 \\
33 \\
119 \\
183 \\
168 \\
193 \\
212 \\
274 \\
1 \\
271 \\
130 \\
268 \\
242 \\
437 \\
318 \\
398 \\
206 \\
179 \\
22 \\
\end{array}$ & $\begin{array}{lr}0- & 925 \\
0- & 1,010 \\
0- & 217 \\
0- & 1,380 \\
0- & 925 \\
0- & 355 \\
0- & 2,280 \\
0- & 708 \\
0- & 807 \\
3- & 5 \\
2- & 13 \\
1- & 20 \\
0- & 1 \\
0- & 640 \\
0- & 204 \\
0- & 209 \\
0- & 140 \\
0- & 105 \\
10- & 180 \\
0- & 633 \\
0- & 300 \\
14 & \\
227 & \\
0- & 3 \\
1- & 528 \\
0- & 89 \\
3- & 32 \\
1- & 131 \\
0- & 528 \\
0- & 1,130 \\
1- & 72 \\
0- & 630 \\
0- & 1,900 \\
0- & 116 \\
0- & 825 \\
0- & 422 \\
0- & 186 \\
0- & 675 \\
0- & 4,570 \\
0- & 1,530 \\
0 & \\
0- & 4,790 \\
0- & 99 \\
0- & 845 \\
0- & 242 \\
0- & 1,140 \\
1-2,090 \\
0- & 567 \\
0- & 780 \\
0- & 276 \\
10- & 562 \\
\end{array}$ & $\begin{array}{c}88 \\
121 \\
38 \\
210 \\
114 \\
42 \\
114 \\
121 \\
76 \\
4 \\
6 \\
11 \\
43 \\
43 \\
19 \\
29 \\
35 \\
16 \\
67 \\
25 \\
38 \\
14 \\
227 \\
6.42 \\
69 \\
16 \\
12 \\
27 \\
130 \\
98 \\
21 \\
41 \\
113 \\
13 \\
58 \\
70 \\
30 \\
54 \\
143 \\
71 \\
6 \\
160 \\
6 \\
120 \\
34 \\
104 \\
143 \\
59 \\
90 \\
11 \\
55\end{array}$ & $\begin{array}{r}9-32 \\
8-33 \\
13-28 \\
12-29 \\
14-29 \\
6-26 \\
11-30 \\
13-29 \\
14-29 \\
14-16 \\
12-14 \\
18-21 \\
4-14 \\
16-30 \\
12-26 \\
16-32 \\
14-31 \\
11-30 \\
17-26 \\
6-29 \\
13-27 \\
20 \\
25 \\
7-19 \\
17-32 \\
14-31 \\
14-20 \\
11-29 \\
17-29 \\
15-36 \\
15-27 \\
11-28 \\
15-35 \\
10-23 \\
14-30 \\
8-29 \\
5-29 \\
12-29 \\
9-29 \\
10-28 \\
15 \\
15-29 \\
13-25 \\
5-28 \\
12-24 \\
5-30 \\
11-28 \\
6-30 \\
8-29 \\
5-24 \\
13-25\end{array}$ & $\begin{array}{l}22 \\
23 \\
19 \\
22 \\
22 \\
17 \\
22 \\
22 \\
23 \\
15 \\
13 \\
19 \\
8 \\
23 \\
21 \\
22 \\
23 \\
22 \\
21 \\
21 \\
21 \\
20 \\
25 \\
13 \\
23 \\
24 \\
17 \\
21 \\
22 \\
25 \\
21 \\
21 \\
29 \\
18 \\
23 \\
17 \\
21 \\
22 \\
22 \\
21 \\
15 \\
22 \\
18 \\
21 \\
18 \\
21 \\
21 \\
21 \\
18 \\
20 \\
\end{array}$ \\
\hline
\end{tabular}

C zone

\begin{tabular}{|c|c|c|c|c|c|c|c|c|}
\hline $343-4 G$ & $7,292.5$ & $7,380.5$ & 27 & 0 & 16 & 5 & $14-22$ & 1 \\
\hline $362-25 R^{-}$ & $6,281.0$ & $6,303.5$ & 12 & 2 & 121 & 42 & $18-26$ & 21 \\
\hline $382-26 \mathrm{R}$ & $5,864.5$ & $5,943.5$ & 5 & 0 & 19 & 6 & $13-26$ & 22 \\
\hline $386-26 \mathrm{R}$. & $6,711.0$ & $6,789.5$ & 28 & 0 & 194 & 55 & $9-29$ & 23 \\
\hline $322-36 R_{-}$ & $6,621.5$ & $7,044.5$ & 56 & $1-$ & 181 & 30 & $14-29$ & 21 \\
\hline $362-36 \mathrm{R}$ & $5,811.5$ & $5,855.5$ & 10 & 0 & 39 & 6 & $11-24$ & 16 \\
\hline $322-32 \mathrm{~S}$ & $6,342.5$ & & & 1 & & & 15 & \\
\hline $366-32 S$ & $6,271.5$ & $6,291.5$ & 9 & 0 - & 33 & 12 & $14-24$ & 20 \\
\hline $\begin{array}{l}326-35 \mathrm{~S} \\
320\end{array}$ & $7,287.5$ & $7,528.5$ & 9 & 0 & 7 & 2 & $10-21$ & 15 \\
\hline $324-31 \mathrm{~T}$ & $9,019.5$ & $9,461.5$ & 252 & 0 & 548 & 14 & $5-24$ & 16 \\
\hline
\end{tabular}

D zone

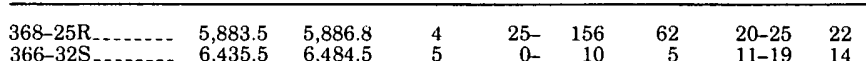


TABLE 5.-Porosity and permeability for cores from wells drilled in Naval Petroleum Reserve No. 1-Continued

\begin{tabular}{|c|c|c|c|c|c|c|c|c|}
\hline \multirow{2}{*}{ Well } & \multicolumn{2}{|c|}{ Cored depth . } & \multirow{2}{*}{$\begin{array}{l}\text { Number of } \\
\text { analyses }\end{array}$} & \multirow{2}{*}{\multicolumn{3}{|c|}{$\frac{\begin{array}{c}\text { Permeability, in } \\
\text { millidarcys }\end{array}}{\text { Range Average }}$}} & \multirow{2}{*}{\multicolumn{2}{|c|}{$\frac{\begin{array}{c}\text { Porosity, in } \\
\text { percent }\end{array}}{\text { Range Average }}$}} \\
\hline & \multicolumn{2}{|c|}{ From To } & & & & & & \\
\hline \multicolumn{9}{|c|}{ MONTEREY SHALE-Continued } \\
\hline \multicolumn{9}{|c|}{ DD zone } \\
\hline $\begin{array}{l}368-25 \mathrm{R} \\
382-26 \mathrm{R}\end{array}$ & $\begin{array}{l}6,226.5 \\
6,570.5\end{array}$ & $\begin{array}{l}6,344.5 \\
6,752.5\end{array}$ & $\begin{array}{r}53 \\
115\end{array}$ & $\begin{array}{l}0- \\
0-\end{array}$ & $\begin{array}{l}55 \\
41\end{array}$ & $\begin{array}{l}38 \\
34\end{array}$ & $\begin{array}{r}15-31 \\
8-27\end{array}$ & $\begin{array}{l}21 \\
20\end{array}$ \\
\hline \multicolumn{9}{|c|}{ E zone } \\
\hline $\begin{array}{l}343-4 \mathrm{G} \\
343-4 \mathrm{G}-\ldots \\
343-4 \mathrm{G} \\
382-26 \mathrm{R} \\
542-31 \mathrm{R}_{\ldots}\end{array}$ & $\begin{array}{l}8,154.5 \\
8,644.5 \\
8,974.5 \\
6,755.5 \\
6,134.7\end{array}$ & $\begin{array}{l}8,201.5 \\
8,829.5 \\
9,064.5 \\
6,793.5 \\
6,469.4\end{array}$ & $\begin{array}{r}26 \\
78 \\
41 \\
33 \\
5\end{array}$ & $\begin{array}{l}0- \\
0- \\
0- \\
0-\end{array}$ & $\begin{array}{l}18 \\
13 \\
11 \\
18\end{array}$ & $\begin{array}{l}5 \\
2 \\
4 \\
0 \\
5\end{array}$ & $\begin{array}{r}6-21 \\
11-23 \\
11-17 \\
12-26 \\
16-22\end{array}$ & $\begin{array}{l}15 \\
18 \\
14 \\
18 \\
18\end{array}$ \\
\hline \multicolumn{9}{|c|}{ McDONALD SHALE OF LOCAL USAGE } \\
\hline $\begin{array}{l}343-4 \mathrm{G}-\ldots \ldots \\
343-4 \mathrm{G}-\ldots \\
556-25 \mathrm{R}-\ldots . \\
\end{array}$ & $\begin{array}{l}9,462.5 \\
9,668.5 \\
6,981.0\end{array}$ & $\begin{array}{l}9,601.5 \\
9,761.5 \\
7,066.0\end{array}$ & $\begin{array}{l}98 \\
24 \\
18\end{array}$ & $\begin{array}{l}0- \\
0- \\
0\end{array}$ & $\begin{array}{l}14 \\
10\end{array}$ & $\begin{array}{l}1 \\
6 \\
.2\end{array}$ & $\begin{array}{r}12-24 \\
3-16 \\
8-12\end{array}$ & $\begin{array}{l}18 \\
11 \\
10\end{array}$ \\
\hline \multicolumn{9}{|c|}{ GOULD AND DEVILWATER SHALE MEMBERS } \\
\hline $556-25 R_{-} \ldots . . . .-$ & $7,103.0$ & $7,104.0$ & 2 & 0 & & 0.1 & $7-8$ & 7 \\
\hline \multicolumn{9}{|c|}{ MEDIA SHALE MEMBER } \\
\hline $556-25 R_{-}-$ & $7,401.5$ & $7,422.5$ & 8 & 0 & 1 & 0.07 & $17-22$ & 19 \\
\hline \multicolumn{9}{|c|}{ CARNEROS SANDSTONE MEMBER } \\
\hline 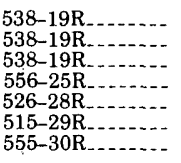 & $\begin{array}{r}8,738.5 \\
8,906.5 \\
9,170.5 \\
7,425.5 \\
10,683.0 \\
8,931.5 \\
9,279.5\end{array}$ & $\begin{array}{r}8,796.5 \\
9,147.5 \\
9,242.5 \\
8,027.5 \\
10,943.5 \\
9,240.5 \\
9,560.5\end{array}$ & $\begin{array}{r}31 \\
183 \\
71 \\
768 \\
47 \\
98 \\
117\end{array}$ & $\begin{array}{l}0- \\
0- \\
0- \\
0- \\
0- \\
0- \\
0-\end{array}$ & $\begin{array}{r}32 \\
20 \\
16 \\
60 \\
2 \\
57 \\
35\end{array}$ & $\begin{array}{c}5 \\
3 \\
6 \\
3 \\
3^{.} .20 \\
{ }_{4}^{4}\end{array}$ & $\begin{array}{r}11-23 \\
3-21 \\
3-20 \\
4-28 \\
3-15 \\
8-25 \\
4-20\end{array}$ & $\begin{array}{l}16 \\
13 \\
15 \\
18 \\
11 \\
18 \\
13\end{array}$ \\
\hline \multicolumn{9}{|c|}{ SANTOS SHALE MEMBER } \\
\hline 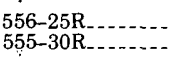 & $\begin{array}{r}8,246.0 \\
10,299.5\end{array}$ & $8,247.0$ & $\stackrel{2}{1}$ & $\begin{array}{ll}16- \\
.0\end{array}$ & 21 & ${ }^{19}{ }_{.0}$ & ${ }_{4}^{20}$ & $\begin{array}{r}20 \\
4\end{array}$ \\
\hline
\end{tabular}

\section{CARNEROS OIL ZONE}

Although thin sandstones in the Santos Oil Zone are the stratigraphically lowest petroleum reservoirs now developed at NPR-1, thick sandstones in the Carneros Oil Zone are the deepest. Some of the producible wells in this zone are perforated at depths exceeding 9,000 feet. The Carneros Oil Zone comprises three sandstones of relatively low porosity and permeability. The First, Second, and Third Carneros sands, as they have been termed locally, range in thickness from a few feet to several hundred feet. They are thickest at the west end of NPR-1 and grade into siltstone and shale eastward across the Elk Hills field. The First and Second Carneros sands persist at least to the middle of the field but disappear before reaching the North Coles Levee field. Carneros sand is absent from the deep Richfield well CLA 67-29T there (pl. 7). Analyses of Carneros sand cores from wells within NPR-1 show average porosities ranging from 11 to 18 percent and average permeabilities ranging from 0.2 to 14 millidarcys.

During 1973, four wells completed in the Carneros Oil Zone in the Elk Hills field and three in the Asphalto field were economic and producible. A single Navy well in the Carneros Oil Zone in the Railroad Gap field was regarded as uneconomic. Subsurface pressures are such that only the gas phase of petroleum is present in the reservoirs, but both gas and condensate are produced under atmospheric pressure at the well head. The producing capacities of the wells range from about 250 to 700 barrels of condensate per day. About 10,000-20,000 cubic feet of gas is produced for each barrel of condensate. If many wells were completed in the Carneros Oil Zone and heavily produced, gas-injection wells and a pressure-maintenance program would be needed. Without pressure maintenance, about half of the reservoir liquids would not be recovered (W. A. Walker, U.S. Navy, Elk Hills, oral commun., 1971).

The separator liquid from petroleum produced from the Carneros Oil Zone in well 538-19R tested $41.1^{\circ} \mathrm{API}$ gravity at $60^{\circ} \mathrm{F}$ (table 6 ). The chemical analysis of the separator gas showed that the gas is about 87 percent methane, 7 percent ethane, 2.5 percent propane, and 2 percent carbon dioxide. The methane content is higher than that determined for samples from the Stevens Oil Zone and the Wilhelm sand zone but about 10 percent less than that for gas from the Mulinia and Scalez sand zones. Salinities of formation water from the Carneros Oil Zone (table 7) range from about 6,000 to $24,000 \mathrm{ppm}$ (parts per million), but most are less than 7,800 ppm.

The three wells completed in the Carneros sand zone in the Asphalto field are produced in order to prevent drainage by wells adjacent to NPR-1. This production has amounted to 337,276 barrels of the 400,000 barrels of oil estimated to be ultimately recoverable. The four wells in the Elk Hills field proper have produced 31,296 barrels of an ultimately recoverable reserve of $4,870,000$ barrels of oil there. The Carneros well in the Railroad Gap field produced 175,216 barrels of oil before being shut in as an uneconomic well. The estimated remaining recoverable reserve from the Carneros wells in the Asphalto and Elk Hills fields is 4,901,248 barrels of oil, and the estimated original reserve for the same wells is $5,270,000$ barrels.

\section{STEVENS OIL ZONE}

About 250 wells have been completed in the Stevens Oil Zone within NPR-1. Their producible rates range from 10 barrels to more than 10,000 barrels per day. Very little oil has been produced from these wells, and so the reservoir energy has not been depleted. It is estimated that the 250 wells could produce 150,000 
TABLE 6.-Analyses of crude petroleum from wells in Naval Petroleum Reserve No. 1

\begin{tabular}{|c|c|c|c|c|c|c|c|c|c|}
\hline \multirow{2}{*}{ Well } & \multirow{2}{*}{ Sample } & \multirow{2}{*}{$\begin{array}{c}\text { Residual } \\
\text { oil gravity } \\
\text { 'API at } 60^{\circ} \mathrm{F}\end{array}$} & \multirow{2}{*}{$\begin{array}{l}\text { Viscosity in } \\
\text { centipoises at } \\
\text { atm pressure }\end{array}$} & \multicolumn{5}{|c|}{$\begin{array}{l}\text { Hydrocarbon analysis } \\
\text { (molecular percent) }\end{array}$} & \multirow{2}{*}{ Remarks } \\
\hline & & & & Methane & Ethane & Propane & $\mathrm{CO}_{2}$ & Other & \\
\hline
\end{tabular}

Dry Gas Zone (samples are formation gas from open-hole drill stem tests)

\begin{tabular}{|c|c|c|c|c|c|c|c|c|c|c|c|}
\hline \multirow[t]{3}{*}{ 368-25R } & DST $1,070-1,407 \mathrm{ft}$ & &.-- & $-\ldots-\ldots$ & 96.42 & 0.42 & 0.05 & 3.03 & & $975 \mathrm{Btu} / \mathrm{ft}^{3}$. & \\
\hline & DST $1,230-1,407 \mathrm{ft}$ & $---1-0-1-4$ & --- & ------- & 96.89 & .14 & .06 & 2.91 & -- & $980 \mathrm{Btu} / \mathrm{ft}^{3}$ & \\
\hline & DST $1,405-1,523 \mathrm{ft}$ & $---1---1$ & --- & $-\ldots--$ & 97.39 & .22 & .10 & 2.21 & -- & $985 \mathrm{Btu} / \mathrm{ft}^{3}$. & \\
\hline \multirow[t]{4}{*}{$64-34 R$} & DST $1,315-1,496 \mathrm{ft}$ & n-n &.- & $-\ldots---$ & 96.84 & .41 & .07 & 2.60 & --- & & \\
\hline & DST $1,713-1,790 \mathrm{ft}$ & $-1-1-1-1$ & -- & ------ & 98.13 & .66 & .17 & .40 & --- & & \\
\hline & DST $1,813-1,935 \mathrm{ft}$ & - & -- & --n-- & 99.07 & .47 & .09 & .30 & --- & & . \\
\hline & DST $1,993-2,100 \mathrm{ft}$ & - & $\ldots$ & $-\ldots---$ & 96.73 & .70 & .30 & 1.10 & $\ldots$ & & \\
\hline \multirow[t]{3}{*}{$86-35 \mathrm{R}$} & DST $1,890-1,960 \mathrm{ft}$ & $----n-1--$ & --- & ------ & 95.90 & .72 & .12 & 3.17 & --- & $980 \mathrm{Btu} / \mathrm{ft}^{3}$. & $\because$ \\
\hline & DST $2,020-2,150 \mathrm{ft}$ & 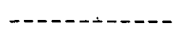 & --- & ------- & 93.19 & .49 & .13 & 6.02 & ---- & $960 \mathrm{Btu} / \mathrm{ft}^{3}$. & \\
\hline & DST 2,225-2,330 ft & - - - - & --- & ------ & 98.07 & .41 & .02 & 1.43 & --- & $980 \mathrm{Btu} / \mathrm{ft}^{3}$. & \\
\hline \multirow{3}{*}{$7-33 S$} & DST $1,793-1,821 \mathrm{ft}$ & 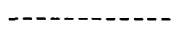 & $-\ldots$ & ------ & 99.3 & --- & --- & .7 & $-\ldots$ & $1,020 \mathrm{Btu} / \mathrm{ft}^{3}$. & \\
\hline & DST $1,839-1,867 \mathrm{ft}$ & --- & $-\cdots$ & $-\cdots-\cdots$ & 97.0 & --- & --- & 3.0 & --- & $1,000 \mathrm{Btu} / \mathrm{ft}^{3}$. & \\
\hline & DST $2,220-2,265 \mathrm{ft}$ & $-----1--$ & $-\cdots$ & $--\ldots--$ & 98.4 & --- & --- & 1.6 & -- & & \\
\hline
\end{tabular}

\begin{tabular}{|c|c|c|c|c|c|c|c|c|c|}
\hline \multicolumn{10}{|c|}{ Scalez sand zone } \\
\hline $\begin{array}{l}73-11 \mathrm{G} \\
54-33 \mathrm{~S}\end{array}$ & $\begin{array}{l}\text { Reservoir fluid at } 3,269 \mathrm{ft} \\
\text { Reservoir fluid at } 2,610 \mathrm{ft} \\
\text { Casinghead gas }-\end{array}$ & $\begin{array}{l}19.8 \\
22.4 \\
---\end{array}$ & $\begin{array}{l}21.9 \text { at } 137^{\circ} \mathrm{F} \\
14.8 \text { at } 127^{\circ} \mathrm{F}\end{array}$ & $\begin{array}{c}2.68 \\
97.71\end{array}$ & $\begin{array}{l}0.03 \\
\overline{1.02}\end{array}$ & $\begin{array}{l}0.11 \\
-. \overline{6}\end{array}$ & $\overline{0.30}$ & $\begin{array}{c}97.18 \\
-\overline{0.51}\end{array}$ & $\begin{array}{l}\text { Bottom-hole sample } \\
\text { supplemented with } \\
\text { additional gas. }\end{array}$ \\
\hline
\end{tabular}

\begin{tabular}{|c|c|c|c|c|c|c|c|c|c|}
\hline \multicolumn{10}{|c|}{ Mulinia sand zone } \\
\hline $42-34 \mathrm{~S}$ & $\begin{array}{l}\text { Reservoir fluid at } 2,950 \mathrm{ft} \\
\text { Casinghead gas }\end{array}$ & $\begin{array}{l}21.5 \\
-\cdots\end{array}$ & 20.3 at $135^{\circ} \mathrm{F}$ & 98.52 & 0.66 & $0.3 \overline{4}$ & 0.30 & $0 . \overline{18}$ & $\begin{array}{l}\text { Bottom-hole sample } \\
\text { supplemented with } \\
\text { additional gas. }\end{array}$ \\
\hline
\end{tabular}

\begin{tabular}{|c|c|c|c|c|c|c|c|}
\hline \multirow[b]{2}{*}{$28-27 \mathrm{R}$} & \multicolumn{7}{|c|}{ Wilhelm sand zone } \\
\hline & Reservoir fluid at $2,600 \mathrm{ft}$ & 41.2 & 1.40 at $131^{\circ} \mathrm{F}$ & $\begin{array}{l}23.85 \\
72.09\end{array}$ & $\begin{array}{r}4.56 \\
11.08\end{array}$ & $\begin{array}{r}6.75 \\
10.03\end{array}$ & $\begin{array}{rr} & 64.84 \\
--- & 6.80\end{array}$ \\
\hline $48-28 R$ & Reservoir fluid at $2,525 \mathrm{ft}$ & $\overline{40 . \overline{5}}$ & 1.48 at $130^{\circ} \mathrm{F}$ & 22.91 & $\begin{array}{r}11.00 \\
6.67 \\
14.36\end{array}$ & $\begin{array}{r}10.00 \\
8.07 \\
10.65\end{array}$ & $\begin{array}{rr}-\cdots & 62.35 \\
-\cdots- & 6.35\end{array}$ \\
\hline $42-34 \mathrm{R}$ & $\begin{array}{l}\text { Reservoir fluid at } 2,674 \mathrm{ft} \\
\text { Separator gas }\end{array}$ & 39.6 & 1.57 at $132^{\circ} \mathrm{F}$ & $\begin{array}{l}23.30 \\
72.03\end{array}$ & $\begin{array}{r}4.89 \\
11.18\end{array}$ & $\begin{array}{l}6.37 \\
9.77\end{array}$ & $\begin{array}{lr}- & 65.44 \\
--- & 7.02\end{array}$ \\
\hline
\end{tabular}

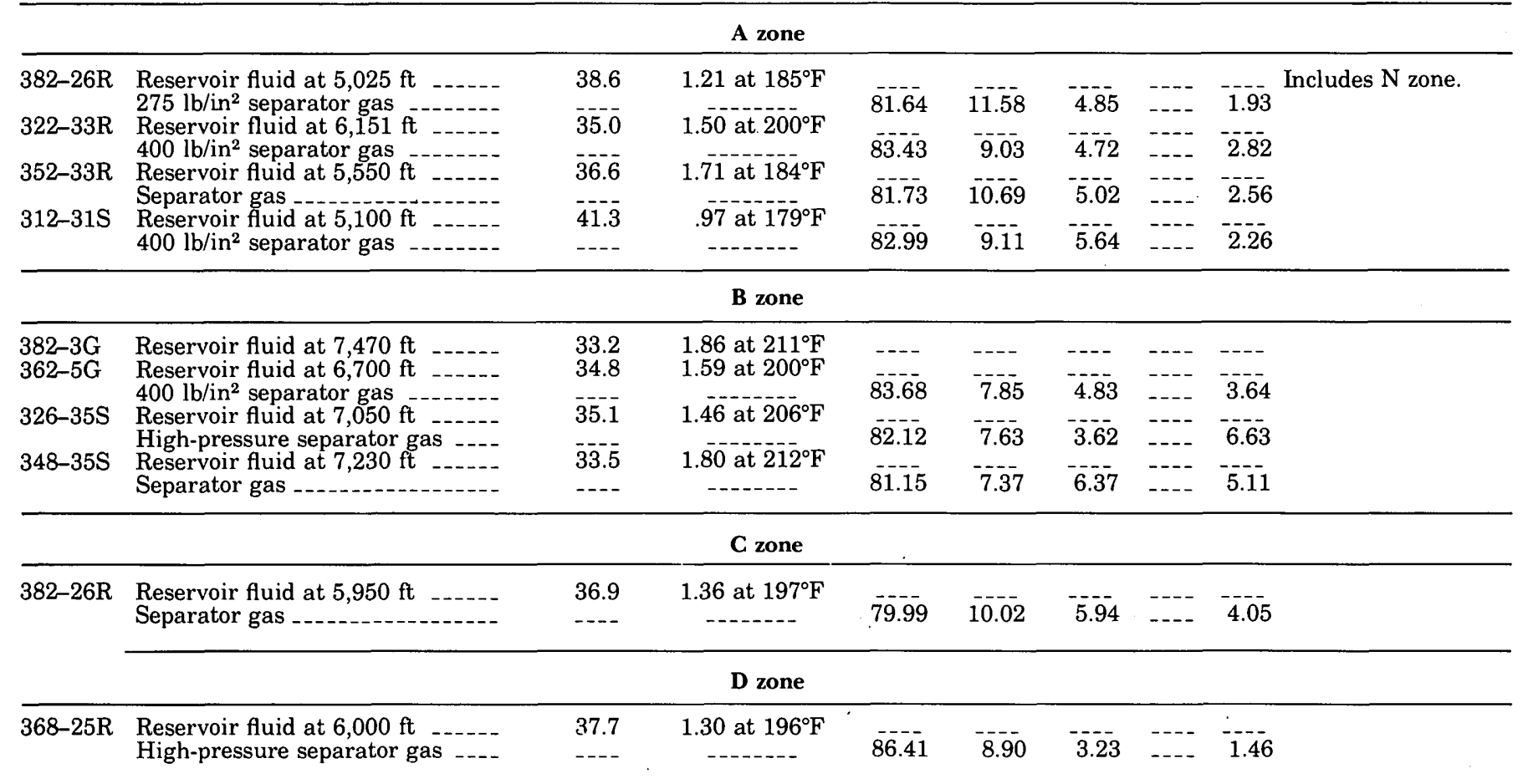


TABLE 6.-Analyses of crude petroleum from wells in Navel Petroleum Reserve No. 1-Continued

\begin{tabular}{|c|c|c|c|c|c|c|c|c|c|}
\hline \multirow{2}{*}{ Well } & \multirow{2}{*}{ Sample } & \multirow{2}{*}{$\begin{array}{l}\text { Residual } \\
\text { oil gravity } \\
\text { oAPI at } 60^{\circ} \mathrm{F}\end{array}$} & \multirow{2}{*}{$\begin{array}{l}\text { Viscosity in } \\
\text { centipoises at } \\
\text { atm pressure }\end{array}$} & \multicolumn{5}{|c|}{$\begin{array}{l}\text { Hydrocarbon analysis } \\
\text { (molecular percent) }\end{array}$} & \multirow{2}{*}{ Remarks } \\
\hline & & & & Methane & Ethane & Propane & $\mathrm{CO}_{2}$ & Other & \\
\hline \multicolumn{10}{|c|}{ D zone - Continued } \\
\hline $325-31 \mathrm{~S}$ & $\begin{array}{l}\text { Reservoir fluid at } 6,688 \mathrm{ft} \\
400 \mathrm{lb} / \mathrm{in}^{2} \text { separator gas }\end{array}$ & 36.5 & 1.25 at $204^{\circ} \mathrm{F}$ & 83.97 & 8.20 & 3.28 & $--\cdot$ & 4.55 & \\
\hline \multicolumn{10}{|c|}{ Carneros sand } \\
\hline $538-19 R$ & $\begin{array}{l}\text { Separator liquid } \\
\text { Separator gas }\end{array}$ & 41.4 & - & $\begin{array}{l}12.47 \\
87.15\end{array}$ & $\begin{array}{l}7.04 \\
7.06\end{array}$ & $\begin{array}{l}8.77 \\
2.46\end{array}$ & $-\overline{2.06}$ & $\begin{array}{r}71.72 \\
1.27\end{array}$ & \\
\hline
\end{tabular}

TABLE 7.-Selected chemical analyses, in parts per million except as indicated, of formation waters from wells in Naval Petroleum Reserve No. 1 [Where more than one analysis is listed, order is according to date, earliest to latest]

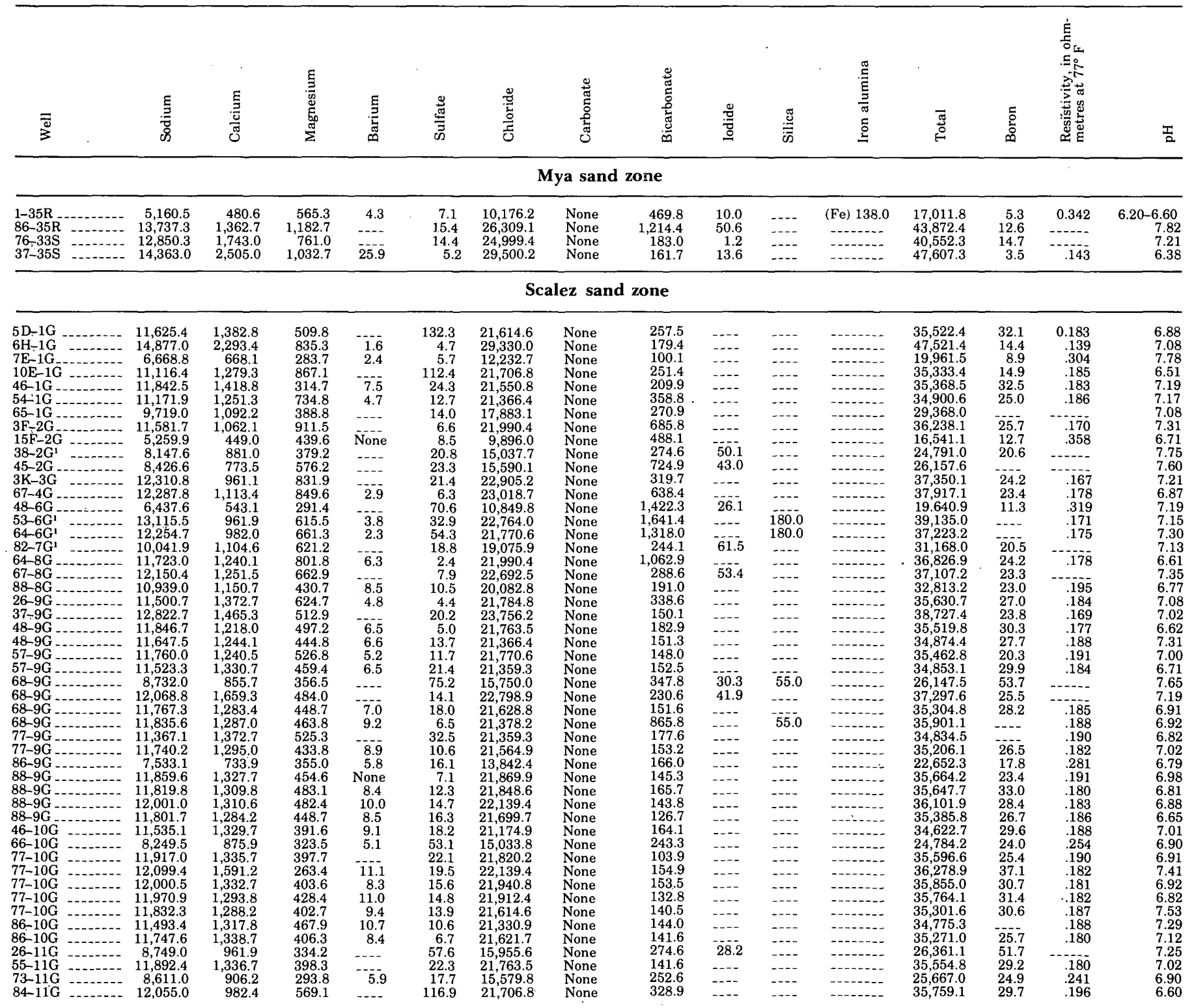


TABLE 7.-Selected chemical analyses, in parts per million except as indicated, of formation waters from wells in Naval Petroleum Reserve No. 1 -Continued

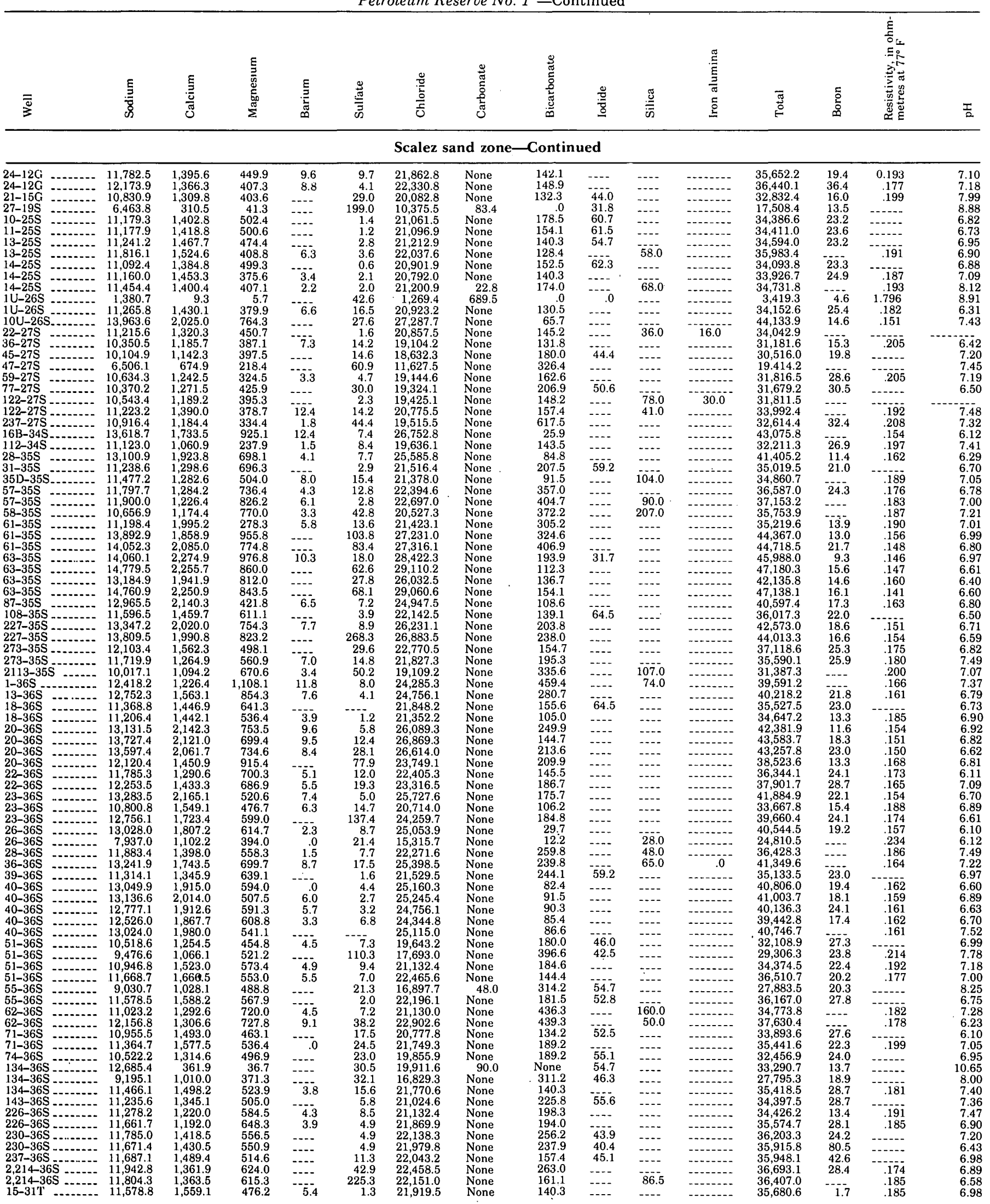


TABLE 7.-Selected chemical analyses, in parts per million except as indicated, of formation waters from wells in Naval Petroleum Reserve No. 1 -Continued

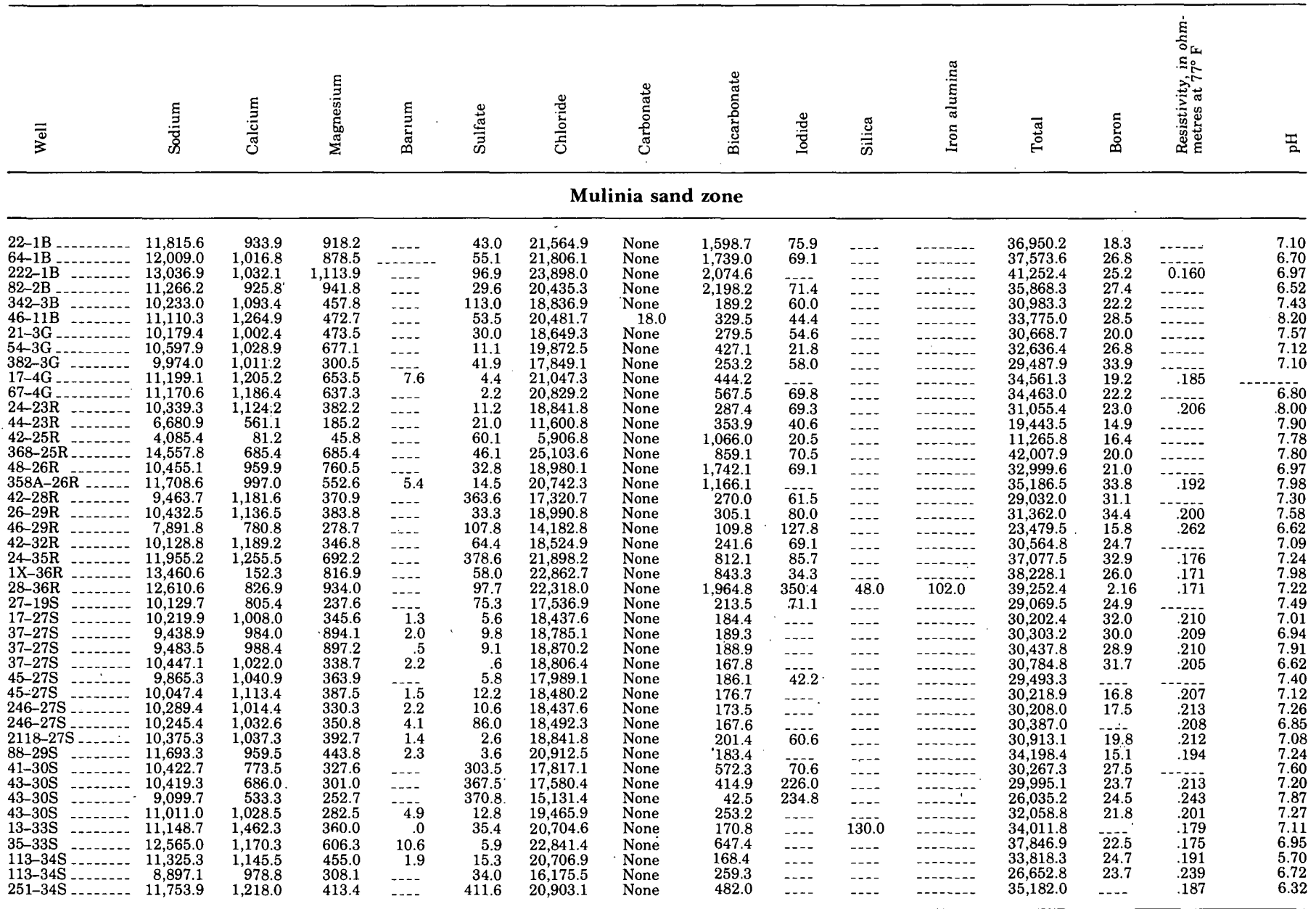

Wilhelm sand zone

\begin{tabular}{|c|c|c|c|c|c|c|c|c|c|c|c|c|c|c|c|}
\hline $242-1 B$ & $11,464.8$ & 917.8 & 412.8 & 0.6 & 7.0 & $20,456.4$ & None & 80.5 & & & & $33,339.9$ & & 0.194 & 5.61 \\
\hline $62-2 \mathrm{~B}$ & $11,253.4$ & $1,426.8$ & $408.9^{\circ}$ & ...- & 479.1 & $20,139.6$ & None & 939.7 . & 101.0 & - & & $34,748.5$ & 32.8 & & 6.95 \\
\hline $48-18 \mathrm{R}$ & $9,452.7$ & 651.3 & 353.4 & $-\cdots$ & 4.9 & $16,577.2$ & None & 274.6 & 59.2 & $-\cdots$ & -... & $27,373.3$ & 42.1 & $\ldots$ & 7.52 \\
\hline $324-19 R$ & $9,782.9$ & 875.5 & 388.4 & $\ldots$ & 5.8 & $17,566.2$ & None & 298.9 & 75.8 & -... & & $28,993.5$ & 42.7 & ......- & 7.20 \\
\hline $48-26 \mathrm{R}$ & $10,948.0$ & 705.0 & 494.0 & -... & 12.3 & $19,198.2$ & None & 586.9 & 68.3 & $-\ldots$ & & $32,012.7$ & 37.2 & -..... & 6.45 \\
\hline $86-28 \mathrm{R}$ & $9,283.2$ & $1,081.1$ & 358.2 & $\ldots$ & 344.8 & $16,884.6$ & None & 182.4 & 77.2 & - & & $28,216.5$ & 33.7 & .231 & 6. \\
\hline $26-29 R$ & $9,310.5$ & 757.3 & 322.6 & .0 & 8.6 & $16,466.2$ & None & 244.1 & 76.5 & $-\cdots$ & & $27,185.8$ & 76.5 & .231 & \\
\hline $84-29 \mathrm{R}$ & $10,023.7$ & $1,041.1$ & 478.3 & .0 & 435.6 & $18,118.5$ & None & 314.2 & 245.7 & 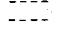 & & $30,657.1$ & 42.9 & .221 & 7.38 \\
\hline $61-32 \mathrm{R}$ & $9,175.1$ & 760.1 & 315.6 & $\ldots$ & 11.5 & $16,225.1$ & None & 274.6 & 67.3 & .... & .... & $26,829.7$ & 147.0 & $\ldots . .-$ & 7.62 \\
\hline $58-34 \mathrm{R} \quad \ldots$ & $10,397.1$ & $1,085.2$ & 325.7 & $-\ldots$ & 397.9 & $18,437.6$ & None & 250.8 & 82.6 & -... & & $30,976.9$ & 33.0 & & 7.98 \\
\hline $22-35 \mathrm{R}$ & $10,931.8$ & $1,231.5$ & 621.4 & 0 & 7.6 & $20,139.6$ & None & $1,165.4$ & 82.2 & $\ldots$ & & $34,179.5$ & 33. & .194 & \\
\hline $28-36 \mathrm{R}$ & $13,131.1$ & $1,970.3$ & 458.2 & ...- & 23.0 & $32,187.9$ & None & & $-\cdots$ & $\ldots$ & (Fe) $5,563.0$ & $53,335.6$ & 26 & .138 & \\
\hline $28-36 \mathrm{R}$ & $11,358.2$ & $1,155.1$ & 428.3 & 36.0 & 12.3 & $20,565.1$ & None & 436.3 & - & $\ldots$ & & $33,991.3$ & 28.6 & .190 & 6.99 \\
\hline
\end{tabular}

Gusher sand zone

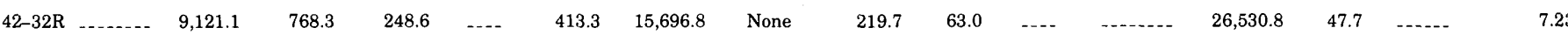

Olig sand zone

\begin{tabular}{llllllllllllllllll}
\hline $37-30 \mathrm{R}$ & $\ldots$ & $\ldots$ & $11,104.3$ & 585.6 & 219.7 & 3.5 & 55.4 & $15,686.2$ & None & $5,287.2$ & 0.0 & $\ldots$ & $\ldots .218$ & 6.92
\end{tabular}

\section{Reef Ridge Shale}

$\begin{array}{rrrrrrrrrrrrrr}373-29 \mathrm{R} & & 2,805.1 & 2.8 & 7.3 & \ldots & 125.9 & 2,375.6 & \text { None } & 3,240.1 & \text { Tr. } & \ldots & \ldots & \\ 312-36 \mathrm{R} \\ \ldots\end{array}$

$$
\text { N zone }
$$

\begin{tabular}{|c|c|c|c|c|c|c|c|c|c|c|c|c|c|c|}
\hline $\begin{array}{l}342-3 \mathrm{~B} \\
314-18 \mathrm{R} \\
336-36 \mathrm{R}\end{array}$ & $\begin{array}{l}8,525.4 \\
6,691.4 \\
9,569.0\end{array}$ & $\begin{array}{r}154.9 \\
72.3 \\
675.3\end{array}$ & $\begin{array}{l}71.4 \\
34.7 \\
37.1\end{array}$ & $\begin{array}{l}\cdots-. \\
-\cdots- \\
-\cdots\end{array}$ & $\begin{array}{r}8.6 \\
59.4 \\
130.5\end{array}$ & $\begin{array}{r}11,158.3 \\
8,644.4 \\
14,126.1\end{array}$ & $\begin{array}{l}\text { None } \\
\text { None } \\
835.3\end{array}$ & $\begin{array}{l}4,222.4 \\
3,179.0 \\
1,451.0\end{array}$ & $\begin{array}{r}30.3 \\
36.4 \\
.0\end{array}$ & $\begin{array}{l}-.-. \\
\overline{14.1}\end{array}$ & - & $\begin{array}{l}24,171.3 \\
18,717.6 \\
26,838.4\end{array}$ & $\begin{array}{r}103.7 \\
87.7 \\
82.2\end{array}$ & $-\cdots . .$. \\
\hline
\end{tabular}


TABLE 7.-Selected chemical analyses, in parts per million except as indicated, of formation waters from wells in Naval Petroleum Reserve No. 1 -Continued

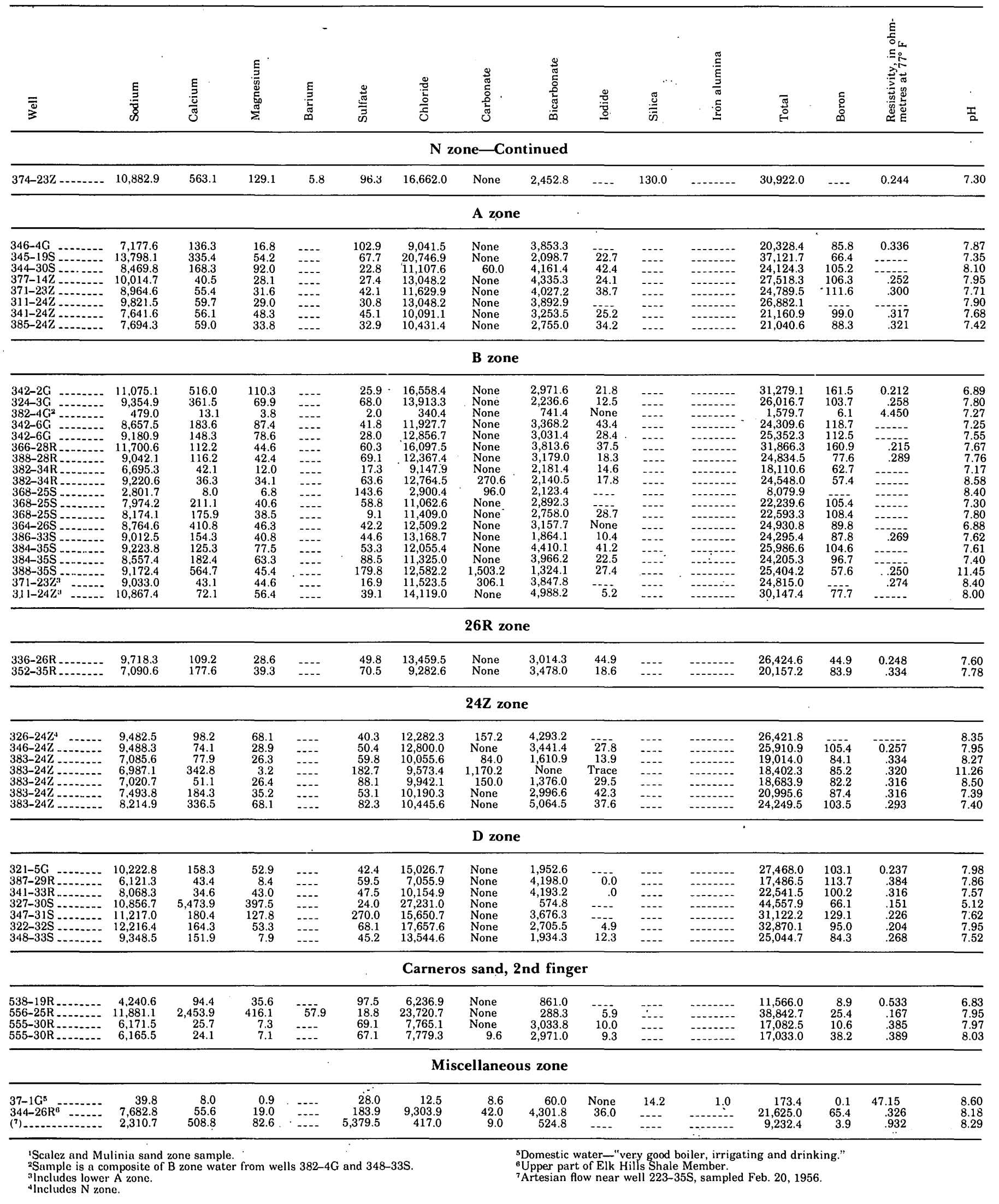


barrels of oil per day, a daily average of 600 barrels from each well (W. A. Walker, U.S. Navy, Elk Hills, oral commun., 1971).

The total production from the Stevens Oil Zone beneath the Elk Hills field to December 31, 1972, was $4,299,145$ barrels of oil. More than twice as much oil has come from the Stevens Oil Zone in the combined production from the Asphalto (9,792,925 barrels) and Railroad Gap fields (194,569 barrels) because the wells there are produced steadily to prevent drainage by wells outside NPR -1 . The estimate of the remaining recoverable reserves in the Stevens Oil Zone in the Elk Hills and Asphalto fields is $683,988,638$ barrels of oil. No study has been made of the Stevens reservoirs at the Railroad Gap field (Department of the Navy, 1973, p. II-26).

The petroleum reservoirs in the Stevens Oil Zone include, in ascending order, the $\mathrm{D}, \mathrm{C}, \mathrm{B}, \mathrm{A}$, and $\mathrm{N}$ zones of the Elk Hills Shale Member and the 24Z (Asphalto) and $26 \mathrm{R}$ sand bodies, which transect the zones. This relation can be seen on the thickness maps of the zones (pls. 18, 19) and is discussed in some detail under the section "Stratigraphy."

The reservoirs in the zones are primarily fractured shale and thin sandstone beds, except for the Main Body $B$ and Western $31 \mathrm{~S}$ sands in the B zone (fig. 33). These are thick sheet sandstones in the $B$ zone that extend from the North Coles Levee field into the eastern and central parts of Elk Hills (pls. 10-12). Analyses of cores from the zones in 86 wells show an average porosity of 19 percent and an average permeability of 44 millidarcys.

The $24 \mathrm{Z}$ and $26 \mathrm{R}$ sands are very thick lenses or pods of sand that transect the $\mathrm{C}, \mathrm{B}, \mathrm{A}$, and $\mathrm{N}$ zones and may occupy all or part of one or more of the zones in different wells. Analyses of cores of the $24 \mathrm{Z}$ and $26 \mathrm{R}$ sands from 37 wells show an average porosity of 22 percent and an average permeability of 191 millidarcys.

Samples of oil and gas from 11 wells producible from the Stevens Oil Zone show that the gravity of the oil ranges from about $33^{\circ}$ to $41^{\circ} \mathrm{API}$ and that the composition of the separator gas ranges approximately from 68 to 87 percent methane, 7 to 12 percent ethane, and 3 to 11 percent propane. Chemical analyses of formation water from 47 wells producible from the Stevens Oil Zone (table 7) show chloride contents ranging approximately from 1,600 to $27,000 \mathrm{ppm}$, but most are between 10,000 and $15,000 \mathrm{ppm}$.

\section{ZONE}

Oil and gas have been found in the $\mathrm{D}$ zone only in the center of the Elk Hills field, on the west end of the Eastern anticline and on the east end of the Western anticline. Deeper drilling in the east and west ends of the field probably will find additional petroleum. Analyses of D zone cores from two wells show average porosities of 14 and 22 percent and average permeabilities of 5 and 62 millidarcys. The gravity of two samples of $\mathrm{D}$ zone oil tested 36.5 and $37.7^{\circ} \mathrm{API}$. The chloride content of formation water from seven wells ranges approximately from 7,000 to $27,000 \mathrm{ppm}$.

\section{ZONE}

Relatively few wells have been completed in the $\mathrm{C}$ zone, and most of these are near the center of the Elk Hills field (pl. 18). Additional production probably will be developed in this zone when more deep wells are drilled to the east and west. The average porosity and average permeability of cores from the $C$ zone in 10 wells are 19 percent and 17 millidarcys, respectively. A single sample of oil from the $\mathrm{C}$ zone had a gravity of $36.9^{\circ}$ API.

\section{B ZONE}

Most wells in the Stevens Oil Zone, other than those drilled specifically for the $24 \mathrm{Z}$ or $26 \mathrm{R}$ sand bodies that transect several zones in the Elk Hills Shale Member, have been completed in the B zone (pl. 18). The B zone reservoirs consist of fractured shale and thin discontinuous sandstones except for the thick tabular Main Body B and Western 31S sands in the eastern part of the Elk Hills field. The productive area of the B zone extends from these thick sandstones at the east end almost to the west end, where the zone is lost in the thick $24 \mathrm{Z}$ sand (pl. 18). An average porosity of 20 percent and an average permeability of 63 millidarcys have been determined for cores of the B zone from 57 wells. The gravity of four oil samples averages $34^{\circ}$ API. The chloride content of the $\mathrm{B}$ zone formation water ranges from 340 to $16,558 \mathrm{ppm}$, but only two of the 19 samples showed less than 9,000 ppm of chloride.

\section{A ZONE}

Production from this zone comes primarily from fractured shale and thin sandstone and siltstone beds. Of 10 sidewall cores recovered from 231 feet of productive reservoir in one well, 4 were shale, 4 were siltstone, 2 were sandstone, and all were oil stained. A zone production extends from the Railroad Gap field on the west entirely across Elk Hills to the North Coles Levee field on the east (pl. 19). Tests of A zone cores from 21 wells gave an average porosity of 18 percent and an average permeability of 17 millidarcys. The gravity of oil samples from the A zone ranges from 35 to 41 degrees. The chloride content of eight samples of A zone formation water ranges from approximately 9,000 to $20,700 \mathrm{ppm}$. 


\section{N ZONE}

The $\mathrm{N}$ zone reservoirs also are fractured shale and thin sandstone and siltstone beds. All but one of the few wells producible from the $\mathrm{N}$ zone are clustered at the west end and middle of the Elk Hills field (pl. 19). A single $\mathrm{N}$ zone well is located near the east end. Cores from two $\mathrm{N}$ zone wells show an average porosity of 16 percent and an average permeability of 6 millidarcys. No gravity determinations are available for the oil. The chloride content of four samples of formation water ranges approximately from 3,000 to $16,600 \mathrm{ppm}$.

\section{SAND-BODY' RESERVOIRS TRANSECTING ZONES}

In the central and western Elk Hills field and in the Asphalto field, the upper four zones of the Stevens Oil Zone are interrupted by two thick sand bodies known as the 24Z (Asphalto) and 26R sands (pls. 8-10; figs. 35, 36). As now known, these are elongate bodies of sand as much as 3 miles long and 1,400 feet thick but only a few thousand feet wide. A total of 63 producible wells have been completed in these sands within NPR-1.

The $24 \mathrm{Z}$ sand was discovered in well $344-24 \mathrm{Z}$ (pl. 2), which was completed as a producible well in May 1946. The discovery well was drilled more than 2 miles northwest of the nearest producible well in the Stevens Oil Zone at that time. Productivity tests as well as geologic data established the $24 \mathrm{Z}$ sand as a separate reservoir within the Stevens Oil Zone. About 16 years later oil was discovered in a similar sand body near Asphalto, now the Asphalto field, and the sand body was termed the "Asphalto sand:" Subsequent drilling between the two areas revealed that the Asphalto sand is the same as the $24 \mathrm{Z}$ sand discovered earlier in the Elk Hills field. Only the name $24 \mathrm{Z}$ sand is used in this report.

The $24 \mathrm{Z}$ sand is an irregular body of sand that extends from the Asphalto field northeastward across sec. $24 \mathrm{Z}$ in the western Elk Hills field (fig. 35). The ends of the sand body have not been defined by drilling, although dry holes at each end may have outlined the field limit of producible petroleum accumulation. Well $363-24 \mathrm{Z}$ in the Elk Hills field found petroleum in the thick $24 \mathrm{Z}$ sand but was drilled deeper for exploratory purposes and completed in the underlying A zone. Well 314-18R showed the $24 \mathrm{Z}$ sand to be thick and permeable but structurally low and filled with salt water. The edge of the oil accumulation lies between these two wells.

Thirty-three wells have been completed in the $24 \mathrm{Z}$ sand within the boundaries of NPR-1 (fig. 35). About half of these, in the $\mathrm{NE}^{1 / 4} \mathrm{sec} .26 \mathrm{Z}$, are produced to prevent loss of oil by drainage to producing wells outside NPR-1. Of the remaining wells (secs. 23Z, 24Z), two have been converted to saltwater-injection wells for the purpose of restoring pressure losses in those areas and thereby preventing the drainage of oil. from Elk Hills field. Cores from 19 of the $24 \mathrm{Z}$ sand wells have been analyzed. These analyses show average porosities ranging from 14 to 32 percent for individual wells and averaging 22 percent for all wells. The average permeabilities range from 16 to 437 millidarcys for individual wells and average 167 millidarcys for all wells. The chloride content of four samples of formation water from the $24 \mathrm{Z}$ sand ranged from 9,573 to $12,800 \mathrm{ppm}$.

The 26R sand lies along the western part of the southwest flank of the Eastern anticline at Elk Hills. This sand body has a maximum width of about 4,000 feet, a maximum thickness of 1,470 feet (fig. 36), and a length established by drilling to date exceeding $2 \frac{11}{2}$ miles. The limits of its oil accumulation at either end have not been defined.

Thirty wells have been completed in the $26 \mathrm{R}$ sand; all are producible at the present time. Because the 26R sandstone body is isolated near the center of the Elk Hills field, no production is necessary to prevent drainage as with the $24 \mathrm{Z}$ sand body. Analyses of cores of the $26 \mathrm{R}$ sand in 16 wells are given in table 5 . The average porosities range from 18 to 29 percent for individual wells and average 24 percent; the average permeabilities range from 38 to 651 millidarcys and average 223 millidarcys for all wells. No chemical analyses of petroleum from the $26 \mathrm{R}$ sand are available. The chloride content of formation water from the sandstone in two wells is recorded as 9,283 and $13,460 \mathrm{ppm}$.

\section{SHALLOW OIL ZONE}

Sand zones in the Shallow Oil Zone consist of many relatively thin interlensing sandstones, siltstones, and shales (pls. 8-16). The Calitroleum sand zone in well 324-19R (pl. 14), for instance, consists of shale and siltstone in the lower one-third and siltstone and sandstone in the upper two-thirds (Berryman, 1973, p. D19). Therefore the thickness of the sand zones shown on plates 22,23 , and 25 represents the thickness of the gross lithologic unit including the reservoir sandstones.

The average porosities and permeabilities of the sandstone reservoirs within the Shallow Oil Zone increase generally upward; thus, the highest values are found in the uppermost Scalez sand zone. The porosities and permeabilities of cores from the Shallow Oil Zone average 31 percent and 458 millidarcys, respectively. These are considerably higher than the average porosity and permeability of the Stevens Oil Zone (19 percent, 44 millidarcys).

Chemical analyses of oil and gas are available for 
samples from the upper part only-the Wilhelm, Mulinia, and Scalez sand zones-and no information is available for petroleum from the lower part-the Calitroleum and Gusher sand zones. The gravity of the oil from the upper three sand zones ranges approximately from $20^{\circ} \mathrm{API}$ in the shallow Scalez sand zone to $41^{\circ} \mathrm{API}$ in the deeper Wilhelm sand zone. This increase in gravity is unusually large for a small increase (500-700 feet) in depth. The ethane and methane content of the gas also seems related to depth: The gas from the shallower, Mulinia and Scalez sand zones is about 98 percent methane, 1 percent ethane, and less than $1 / 2$ percent propane; gas from the deeper, Wilhelm sand zone is about 68-72 percent methane, 5-14 percent ethane, and 6-11 percent propane. Most samples of formation water from the upper three sand zones tested from 17,000 to $26,000 \mathrm{ppm}$ of chloride. The chloride content shows a slight decrease with depth-perhaps a difference of a few thousand parts per million between formation water from the Scalez and the Wilhelm sand zones.

Wells capable of producing large volumes of petroleum from the Shallow Oil Zone were not uncommon during the early development of the Elk Hills field. The Carman No. 1 is reported to have flowed oil at the rate of 10,000 barrels per day in 1919. Present capabilities of wells in the Shallow Oil Zone range from 3 barrels to about 1,000 barrels of oil per day. At the end of 1972, there were 722 producible wells in the Shallow Oil Zone, 4 of them off the reserve in sec. 17G. Navy engineers estimate that the wells are capable of producing about 100,000 barrels of oil per day, or an average of slightly more than 138 barrels of oil per day per well. In March 1971 , many Shallow Oil Zone wells were put on production for a state-of-readiness test. Within 6 hours the goal of the test-a rate of 60,000 barrels of oil per day-was achieved, and this rate was sustained for a period of 5 days (W. A. Walker, U.S. Navy, Elk Hills, oral commun, 1971).

The Shallow Oil Zone has been produced more extensively than the other oil zones at Elk Hills. Large amounts were produced between 1920 and 1926 and again during World War II. A peak rate of production of 65,000 barrels of oil per day was reached in 1945 (Butterfield, 1967, p. 301). As of December 1972, cumulative production was $280,169,912$ barrels of oil, about 47 percent of the ultimate recovery estimate of $598,659,627$ barrels (Department of the Navy, 1973, p. II-25). Remaining reserves are estimated to be $318,489,715$ barrels of oil.

Olig sand zone.-The Olig sand zone is a thick northeastward-thinning sandy wedge at the base of the Tupman Shale Member of the Etchegoin Formation in the Railroad Gap, Asphalto, and southwestern Elk Hills oil fields (pl. 13; fig. 37). It is more than 900 feet thick in the Asphalto field, where the only four wells completed in the Olig sand zone are located. Only one of these wells was producible in 1972. The thin edge of the sandy wedge lies on the southwest flank of the Western anticline of Elk Hills. The Olig sand zone is absent from the crest. The average porosities of Olig sand cores from three wells, none of which produce from the Olig sand zone, are 20,21 , and 22 percent, the average permeabilities range more widely from 3 to 103 millidarcys and average 40 millidarcys. No chemical analyses of petroleum from the Olig are available. A single sample of formation water shows a chloride content of about $15,700 \mathrm{ppm}$. The total production from the one Olig well in NPR-1 amounts to only 1,412 barrels of oil. Reserves have not been estimated.

Calitroleum sand zone.-The only well completed in the Calitroleum sand zone in NPR-1 is located on the southwest flank of the Eastern anticline near the center of the Elk Hills field. Tests of cores from the Calitroleum sands in two wells showed an average porosity of 32 percent and an average permeability of 17 millidarcys. No chemical analyses of petroleum or formation water from the one well completed in the Calitroleum sand zone are available.

Gusher sand zone.-Although five wells near the crest of the Eastern anticline have produced some petroleum from the Gusher sand zone, only one well remains completed in the zone. The Gusher sands have relatively high porosities and generally low permeabilities. The average porosities of cores from. 11 wells riange from 28 to 47 percent and average 32 percent; the average permeabilities range from 5 to 1,389 millidarcys and average 190 millidarcys. However, the average porosity of only one well exceeded 35 percent, and the average permeabilities of only two wells exceeded 75 millidarcys. No chemical analyses of petroleum or formation water from the Gusher sand zone are available.

Wilhelm sand zone.-A total of 77 wells have been completed in Wilhelm sands, but 27 of these have since been abandoned. With one exception, all wells completed in the Wilhelm sand zone are clustered at the southeast end of the Western anticline and on the southwest flank of the Eastern anticline. The exception is an isolated well on the Eastern anticline on the faulted nose that extends toward the North Coles Levee field (pls. 4, 23). The average porosities of Wilhelm cores from 34 wells range from 23 to 40 percent and average 32 percent; the average permeabilities range from 15 to 445 millidarcys and average 82 millidarcys. Analyzed samples of petroleum from three Wilhelm wells show the gravity ranges from $39.6^{\circ}$ to $41.2^{\circ} \mathrm{API}$ and the gas contains 69-72 percent methane, 11-14 percent ethane, and 10-11 percent propane. The chloride content of 15 
samples of formation water from the Wilhelm sand zone ranges approximately from 16,000 to $32,000 \mathrm{ppm}$.

Mulinia sand zone.-Three hundred thirty-four wells, of which 280 are presently productive, have been completed in Mulinia sands. Most productive wells are located on the faulted eastern part of the Eastern anticline, where the Mulinia sand zone is 300-450 feet thick. Some productive wells are at the northwest end of the Eastern anticline, and a few more are scattered along. the southeast nose and southwest flank of the Western anticline (pl. 23). The average porosities of Mulinia cores from 87 wells range from 24 to 41 percent for individual wells and average 34 percent for the zone; the average permeabilities range from 16 to 4,802 millidarcys for individual wells and average 990 millidarcys for the zone. The gravity of a single sample of oil is $21.5^{\circ} \mathrm{API}$; the gas contains 98.5 percent methane, 0.7 percent ethane, and 0.3 percent propane. Both the low gravity of the oil and the high percentage of methane in the gas mark an appreciable difference between the petroleum of this zone and the zones below. The chloride content of formation water from the Mulinia sands ranges approximately from 5,900 to $25,000 \mathrm{ppm}$, with most determinations between 18,000 and 22,000 ppm.

Scalez sand zone.-The Scalez sand zone is the lowermost unit of the San Joaquin Formation. A total of 667 wells have been completed in the Scalez sand zone; most of these were producible in 1973 (pl. 25). All Scalez wells are located in the faulted area in the east half of the Elk Hills field. This concentration of wells is a result of the first oil discovery in the Scalez sands being made in this east end area and the consequent early development drilling. The porosities and permeabilities of the Scalez sands are the highest of the oil-bearing reservoirs in NPR-1. The average porosities from 115 wells range from 27 to 44 percent and average 34 percent. The average permeabilities range from 4 to 4,770 millidarcys and average 1,428 millidarcys. Analyses of petroleum samples from two wells show gravities: of $19.8^{\circ}$ and $22.4^{\circ} \mathrm{API}$. The gas contains approximately 98 percent methane, 1 percent ethane, and 0.5 percent propane. The chloride content of formation water of the Scalez sands in 87 wells ranges approximately from 1,300 to $29,000 \mathrm{ppm}$, but most samples showed 18,000 $25,000 \mathrm{ppm}$. This water and that of the underlying Mulinia sand zone is considerably more salty than the formation waters from all deeper reservoir samples at Elk Hills.

\section{DRY GAS ZONE}

The Dry Gas Zone has been penetrated by more than 1,000 wells; only six wells have been completed in it, and only five of these are now producible (Fishburn, 1973, p. 1, 2; Department of the Navy, 1973, p. II-22). Well 1X-36R (pl. 25) was reported as completed and later abandoned in a Mya gas sand, but the well record is incomplete and suspect. As of December 31, 1972, the cumulative production of gas was 99,766,848 Mcf (thousand cubic feet), and the estimated recoverable reserves remaining were 220,192,762. Mcf. These figures combined give $319,959,610 \mathrm{Mcf}$ as the estimated original recoverable reserves. Although some heavy oil in undetermined quantities has been noted near the base of the Tulare Formation in well 526-30R and others at Elk Hills, no tests have been made, and no estimate of additional oil reserves from this source is possible.

Mya sand zone.-Six wells are completed in the Mya sand zone, five of which are now producible and are located near the center of the Elk Hills field. Dry gas from these wells makes up the total production $(99,766,848 \mathrm{Mcf})$ and estimated remaining recoverable reserves $(220,192,762 \mathrm{Mcf})$ of the Dry Gas Zone as of December 31, 1972. The average porosities of Mya sand cores from 10 wells range from 33 to 39 percent and average 36 percent for all cores. The average permeabilities range approximately from 300 to 3,300 millidarcys and average 1,275 millidarcys. The average porosity of the Mya sands is higher than for any other sand or fractured-shale zone at Elk Hills. The average permeability is second only to that of the Scalez sand zone. Chemical analyses of the Mya dry gas show that it contains approximately 93-99 percent methane, 0.1-0.7 percent ethane, and 0.02-0.3 percent propane. Its heat value ranges from 960 to 1,020 British thermal units per cubic foot. The chloride content of formation water ranges approximately from 10,000 to $29,500 \mathrm{ppm}$, but three of the four determinations were 25,000 ppm or more. This high chloride content follows a pattern of increasing salinity in younger beds at Elk Hills.

\section{PRODUCTION AND RESERVES}

According to Navy records; a total of 294,$652 ; 048$ barrels of oil had been produced from NPR-1 by December 31,1972 (table 8). Most of the oil, $280,169,912$ barrels, came from the Shallow Oil Zone, which is now about 47 percent depleted. The Stevens Oil Zone contains the largest remaining reserves of oil $(683,988,638$ bárrels); only 2 percent of the Stevens Oil Zone has been produced. More than 99 billion cubic feet of gas have been produced from the Dry Gas Zone, and two-thirds of the original reserves remain. Appreciable volumes of this gas have been injected into the Shallow Oil Zone, and some of the injected gas will be produced again. Present estimates of the oil reserves of the Carneros Oil Zone are small $(4,901,428$ barrels), but additional deep drilling will probably increase the known reserves of this reservoir. The Carneros Oil Zone in the Elk Hills and Asphalto fields is about 7 percent depleted. Re- 
TABLE 8.-Oil production recorded since establishment of Naval Petroleum Reserve No. 1

[Source: Naval Petroleum Reserve No. 1 unpublished records]

\begin{tabular}{|c|c|c|c|c|c|}
\hline Year & $\begin{array}{c}\text { Yearly } \\
\text { production } \\
\text { (barrels) }\end{array}$ & $\begin{array}{l}\text { Cumulative } \\
\text { production } \\
\text { (barrels) }\end{array}$ & Year & $\begin{array}{c}\text { Yearly } \\
\text { production } \\
\text { (barrels) }\end{array}$ & $\begin{array}{l}\text { Cumulative } \\
\text { production } \\
\text { (barrels) }\end{array}$ \\
\hline 1919 . & 284,330 & 284,330 & 1946. & $3,852,179$ & $194,007,646$ \\
\hline 1920 & $7,362,050$ & $7,646,380$ & 1947. & $2,467,828$ & $196,475,474$ \\
\hline 1921. & $17,868,230$ & $25,514,610$ & 1948 & $2,178,127$ & $198,653,601$ \\
\hline 1922 & $11,601,584$ & $37,116,194$ & 1949. & $3,166,478$ & $201,820,079$ \\
\hline 1923. & $8,015,544$ & $45,131,738$ & 1950. & $2,833,318$ & $204,653,397$ \\
\hline 1924 & $13,458,155$ & $58,589,893$ & 1951 . & $2,563,505$ & $207,216,902$ \\
\hline 1925 . & $11,985,337$ & $70,575,230$ & 1952 . & $2,995,544$ & $210,212,446$ \\
\hline 1926 & $12,233,172$ & $82,808,402$ & 1953. & $6,167,436$ & $216,379,882$ \\
\hline 1927. & $9,960,675$ & $92,769,077$ & 1954 & $7,871,134$ & $224,251,016$ \\
\hline 1928 & $8,097,633$ & $100,866,710$ & 1955. & $6,826,982$ & $231,077,998$ \\
\hline 1929 & $6,323,200$ & $107,189,910$ & 1956 & $6,093,195$ & $237,171,193$ \\
\hline 1930 & $6,548,836$ & $113,738,746$ & 1957. & $5,786,447$ & $242,957,640$ \\
\hline 1931 . & $4,911,673$ & $118,650,419$ & 1958 & $5,395,324$ & $248,352,964$ \\
\hline 1932 & $4,528,474$ & $123,178,893$ & 1959 & $5,253,179$ & $253,606,143$ \\
\hline 1933 & $4,472,130$ & $127,651,023$ & 1960. & $4,499,688$ & $258,105,831$ \\
\hline 1934 & $\begin{array}{l}4,339,311 \\
3,3311\end{array}$ & $130,990,334$ & 1961 . & $\begin{array}{r}4,499,000 \\
4,135,245\end{array}$ & $262,241,076$ \\
\hline 1935 & $3,210,702$ & $134,201,036$ & 1962 & $3,959,880$ & $266,200,956$ \\
\hline 1936 & $3,292,547$ & $137,493,583$ & 1963 & $4,138,558$ & $270,339,51$ \\
\hline 1937. & $3,775,325$ & $141,268,908$ & 1964 & $4,431,612$ & $274,771,126$ \\
\hline 1938 & $3,872,001$ & $145,140,909$ & 1965 & $3,818,541$ & $278,589,66$ \\
\hline 1939. & $3,820,899$ & $148,961,808$ & 1966 & $3,344,570$ & $281,934,237$ \\
\hline 1940 & $4,425,904$ & $153,387,712$ & 1967. & $2,958,489$ & $284,893,086$ \\
\hline 1941 & $3,466,275$ & $156,853,987$ & 1968 & $2,859,919$ & $287,753,005$ \\
\hline 1942 & $4,275,383$ & $161,129,370$ & 1969 & $2,306,961$ & $290,059,966$ \\
\hline 1943 & $5,390,414$ & $166,519,784$ & 1970 & $1,812,979$ & $291,872,945$ \\
\hline 1944 & $7,718,963$ & $174,238,747$ & 1971 & $1,765,772$ & $1293,316,374$ \\
\hline 1945 & $15,916,720$ & $190,155,467$ & $1972 \ldots$ & $1,314,480$ & ${ }^{1294,652,048}$ \\
\hline
\end{tabular}

${ }^{1}$ Adjusted to reconcile with unit production records

serves in the Railroad Gap field are believed to be minor and have not been calculated.

About 3,600 barrels per day were produced from NPR-1 during 1972 as a result of testing and drainageprevention programs. This totaled $1,314,480$ barrels of oil for the year. The largest yearly production occurred in 1921 (fig. 50; table 8), when $17,868,230$ barrels of oil was produced, mostly by the Standard Oil Company of California. The second largest yearly production, $15,916,720$ barrels of oil, came in 1945 as a result of the World War II program for increasing production for wartime needs. After the war years, production declined steadily as a result of Navy's effort to preserve as much oil in the ground as possible. During 1972, the amount of oil produced $(1,314,480$ barrels) was the smallest since 1919 (284,330 barrels), the year petroleum was discovered at Elk Hills.

Original recoverable reserves of NPR-1 are estimated to have been $1,302,010,335$ barrels of oil (Department of the Navy, 1973, p. II-24). This estimate indicates $1,007,358,287$ barrels of oil remain, about 77 percent of the original recoverable reserves estimated on the basis of existing wells. However, new reserves will almost surely be developed as a result of future exploration, both vertically and laterally, for stratigraphic as well as structural accumulations of petroleum along this complex anticlinal trend. The reserve figures will increase also as secondary and tertiary recovery methods are improved and as the price of oil increases sufficiently to influence decisions to complete wells of small capacity now abandoned as uneconomic.

The production of NPR-1 has been largely the result of a continuing test program designed to keep the Elk Hills field in a state of readiness for national emergencies. Some other production results from a program of producing edge wells in an effort to slow the encroachment of salt water up the flanks of the Elk Hills structure and from a program of producing wells in areas of NPR-1 that are adjacent to the Elk Hills field and therefore subject to drainage. The areas subject to drainage are extensions of the Asphalto, Railroad Gap, North Coles Levee, and Buena Vista Front oil fields (fig. 51). All but Buena Vista Front produce primarily from reservoirs of Miocene age; Buena Vista Front,- a northward extension of the Buena Vista field, produces from the Shallow Oil Zone of Pliocene age.

The existing 996 wells in NPR-1 are estimated to be capable of producing about 250,000 barrels of oil per day. The capacity of the existing pipeline from NPR-1 is only 25,000 barrels per day, and storage can now be provided for only 30,000 barrels of oil at the Standard Oil Company tank farm near the south limit of Elk Hills. If full production of NPR-1 were demanded, additional pipeline connections, flow lines, separators, gas compressors, and tankage would be required.

The Navy has several contingency plans for producing oil at different rates for different periods of time. Under one of these plans, it is estimated that NPR-1 could produce 230,000 barrels of oil per day for 5 years with the necessary surface equipment and some additional wells (W. A. Walker, U.S. Navy, Elk Hills, oral commun., 1971).

\section{ORIGIN AND ACCUMULATION OF PETROLEUM AT ELK HILLS}

Petroleum has been defined as a naturally occurring complex mixture of chemicals composed predominantly of compounds of hydrogen and carbon. It is one stage in the transformation of the organic substance of living organisms to the final products methane and graphite (Silverman, 1971, p. 48). It is generally believed that the transformation process is not necessarily completed in the source beds but may continue from genesis through the migration stage and even into the entrapment and accumulation period. The most commonly. accepted theory for the origin of petroleum is the biogenetic theory, which holds that the primitive source of oil and gas is organic matter formed by decomposition of vegetable and animal deposits in subaqueous finegrained sandstone. The increase in temperature and pressure as burial of the sediments progresses leads to various chemical reactions resulting in the development of hydrocarbons and other oil and gas constituents from the organic matter (Mirchink and others, 1971, p. 28-29). 


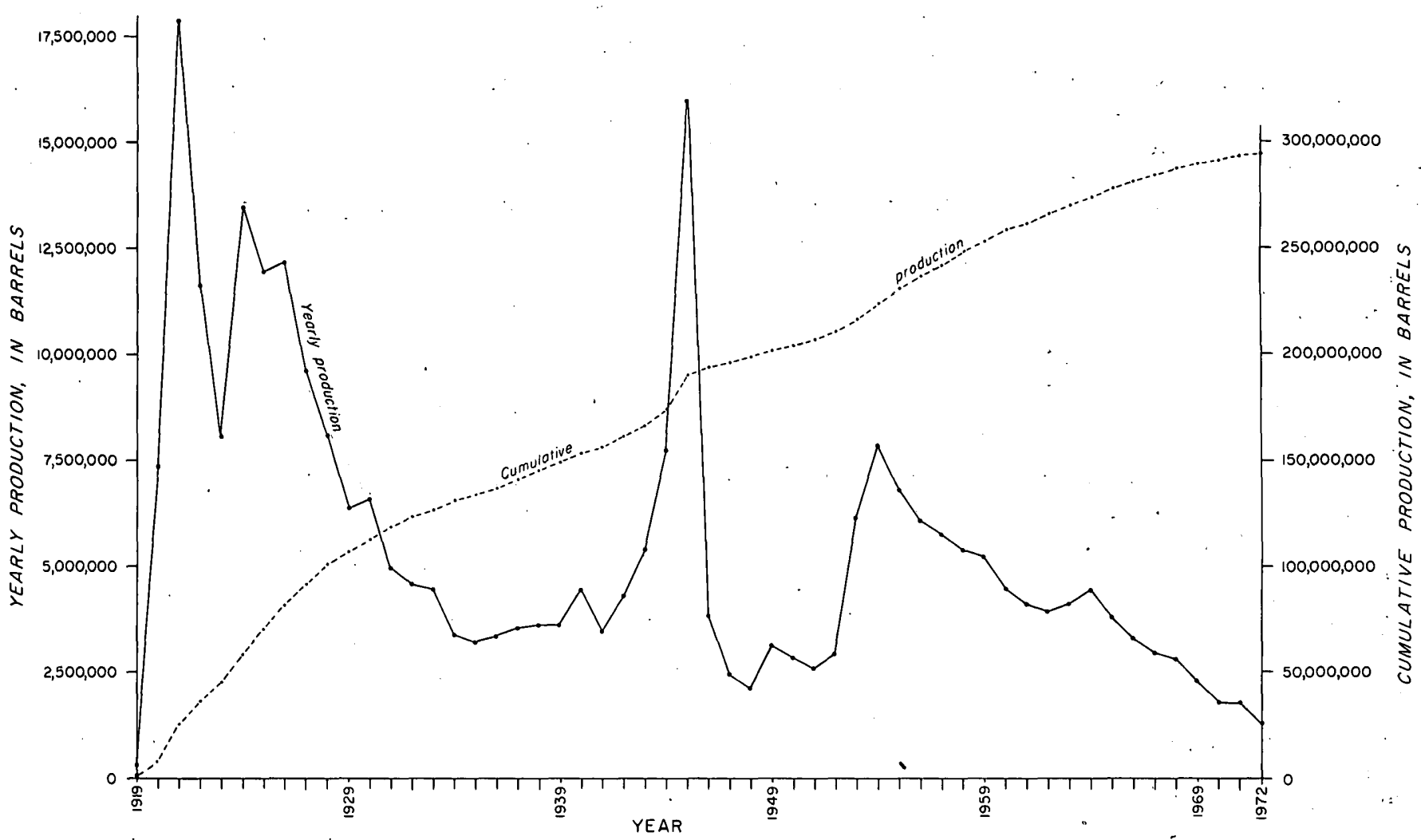

FIGURE 50.-Yearly and cumulative production of oil recorded since establishment of Naval Petroleum Reserve No. 1.

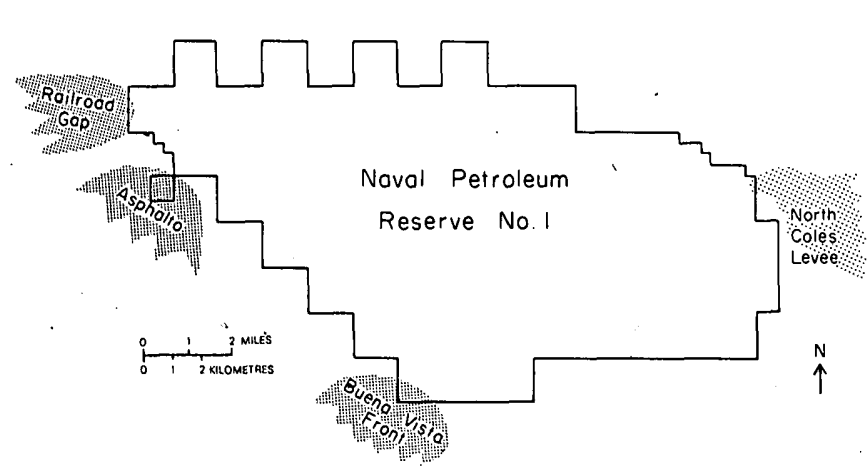

Figure 51.-Oil fields that extend onto Naval Petroleum Reserve No. 1 .

The generation of petroleum and its first movement is thought to begin in source beds at about 3,000 feet, to increase greatly from $5,000-9,000$ feet, and to decrease gradually below that depth (Cordell, 1972, p. 20292067). Hydrocarbons may be generated in some places at shallow depths shortly after deposition of the sediments, but their composition is unlike that of the hydrocarbons found in crude oil. Apparently the hydrocarbons in crude oil require extended periods of heat and pressure to mature.

Primary migration, the movement from source beds to the reservoir system, is initiated by the expression of the fluid hydrocarbons from the capillary pores of the fine-grained carbonaceous source rocks. All migration, primary or secondary, is usually considered to occur in water-saturated rocks. Reduction in porosity because of compaction during subsidence and burial tends to express the pore waters and their dissolved or emulsified hydrocarbons from the finer grained and less permeable source rocks into coarser grained and more permeable and porous carrier and reservoir beds (McCulloh, 1973, p. 486).

Secondary migration, the movement of the petroleum (or protopetroleum) in the carrier bed, is constant toward regions of lower pressure, usually toward the ground surface. Movement continues until the petroleum escapes at the surface or encounters a barrier or trap that prevents further movement. Hydrocarbons slowly accumulate in such a trap until released by erosion or tectonic movement, or the drill.

The deeper parts of the southern San Joaquin Valley received marine sediments continuously from the close of the Coast Range orogeny in middle Eocene time to middle Pliocene time, a period of 40-45 million years. Most marine deposits consisted of fine-grained clastic sediments rich in organic material, generally regarded as suitable sources of petroleum.

The shallowest sizeable oil accumulation at Elk Hills is that in the Scalez sand zone, which is buried to depths 
of 2,000-3,000 feet in most of the field. This is the depth range suggested by Gussow (1955, p. 554) for the beginning of expulsion of source-bed fluids into reservoirs. It seems likely to the writers that the oil at Elk Hills came from both Miocene and Pliocene shales, particularly the Elk Hills Shale Member of the Monterey Shale and the Reef Ridge Shale, both of Miocene age, and the Tupman Shale Member in the Etchegoin Formation of Pliocene age.

The area of source rocks from which petroleum drained into the Elk Hills structure is indeterminate. However, it seems likely that much of the petroleum came from the source rocks in the Tejon basin and the trough of the southern San Joaquin basin. It was trapped on the Elk Hills anticlinal feature in its movement toward the west edge of the basin, where numerous seeps and tar sands attest to this regional migration.

Gussow (1968, p. 359-360) envisioned oil migrating updip into the Paloma field (fig. 28), spilling updip from there into the South Coles Levee field, and thence into the North Coles Levee and Elk Hills fields successively. Nothing in this study has been found to discredit this theory for accumulation of oil at Elk Hills.

The traps at Elk Hills are formed by sheet or tabular sands draped over the anticline, by lenticular sands and pod-shaped sand bodies not necessarily on the high part of the structure, and by zones of fractured siliceous shale, mostly along the fold axes. Fault traps are relatively unimportant. The few faults in the upper Miocene beds have neither caused nor appreciably affected the Miocene oil accumulations and do not extend upward into the Pliocene rocks. The numerous shallow faults in the. Pliocene rocks on the Eastern anticline developed after the oil was trapped and only served to adjust or shift slightly the existing accumulations.

The source of most gas at Elk Hills probably is the same as the oil, but the source rocks for the dry gas in the shallow Pliocene sand zones may be different. Analyses in table 6 show that most gas in the Mulinia, Scalez, and Mya sand zones is about 98 percent methane and less than 1 percent ethane and propane. The carbon dioxide content ranges from 0.3 to 6.0 percent. This contrasts sharply with the composition of the deeper gas, which ranges from 69 to 87 percent methane and 9 to 25 percent ethane and propane. The composition of the dry gas is similar to that of "marsh gas," commonly associated with decaying vegetable matter in brackish-water marshes. The sediments of the Mulinia sand zone mark the beginning of a transition from a shallow marine environment to brackish-water and nonmarine conditions in Pliocene time. Many beds below the Mulinia sand zone contain abundant glauconite and fish scales; beds in the Mulinia, Scalez, and
Mya sand zones contain abundant plant fragments and carbonaceous material. This suggests that much of the dry gas in these upper zones has come from vegetable matter buried in lagoons, estuaries, tidal flats, and lakes and decomposed at shallow depth.

\section{FUTURE EXPLORATION}

\section{SHALLOW AND INTERMEDIATE ZONES}

The Tulare Formation produces oil in the Railroad Gap and many other oil fields in the southwestern part of the San Joaquin Valley, but it has not been systematically evaluated for hydrocarbons in the Elk Hills field. In many wells, surface casing was set through the Tulare Formation before an electric log was run. During the drilling of well 526-30R in 1968, heavy oil staining was noted in a fine- to coarse-grained sandstone near the base of the Tulare. Sidewall cores were taken at depths of $1,179,1,183$, and 1,188 feet. Analyses revealed porosities of 30.7-35.4 percent, permeabilities of 655730 millidarcys, and oil saturations of 47.1-55.4 percent. The gravity of the contained oil ranged from $15^{\circ}$ to $18^{\circ}$ API. A review of electric logs of nearby wells showed highly resistive sands at about the same stratigraphic horizon in wells 545-25Z, 37-30R, and 55-30R. Large accumulations of oil may not be present in such sands beneath Elk Hills, but even smäl accumulations could be easily tapped in multiple completions in wells producing from lower reservoirs. As wells producible from lower zones are abandoned, it may be advisable to consider testing some of the highly resistive zones of the lower Tulare Formation as shown on available electric logs.

The Dry Gas Zone and the Shallow and Stevens Oil Zones beneath NPR-1 are only partially explored despite the existence of nearly 1,000 producible wells. Most of the wells are concentrated on the Eastern and Western anticlines, and these zones have not been tested in large areas of the reserve. Structure maps (pl. 4) in this report show numerous structurally high areas where step-out wells could be expected to add to the reserves. In addition, the stratigraphic relations discussed indicate that stratigraphic traps may be present off the flanks of the anticlines. Detailed mapping of individual sand bodies, both the productive ones and the presently nonproductive ones, should provide many favorable drilling locations.

Fractured-shale reservoirs (Stevens Oil Zone) that contain much of the oil reserves of Elk Hills coincide with the crests of the folds (Elk Hills Engineering Committee, 1957b, maps 9-22) except for the $\mathrm{N}$ zone on the Eastern anticline, where the productive area of the fractured shale terminates rather abruptly eastward. At this point the crest of the fold is broader, and the 
flank dips are gentler than those to the west, which suggests that the folding has not been sharp enough to produce the fractures necessary for an oil reservoir in shale. If fractured-shale reservoirs are related to the crests of sharp folds, some small surface folds observed at Elk Hills as well as larger structural features may have oil reservoirs in the shales of the Stevens Oil Zone.

Sandstone reservoirs in the Stevens Oil Zone also offer additional possibilities for exploration, particularly the $24 \mathrm{Z}$ and $26 \mathrm{R}$ sands. These are pod-shaped linear bodies that have not been delimited completely at their ends. Opportunities for extending the productive area of the $24 \mathrm{Z}$ sand to the northeast are favorable, especially where the sandstone intersects anticlinal features.

The primary source of sand in Miocene time at Elk Hills was apparently to the southwest. It is possible that other sand pods similar to the $24 \mathrm{Z}$ and $26 \mathrm{R}$ sands may be found wedged out along the south flank of Elk Hills, an area in which no deep wells have been drilled (pl. 4). Shallow-water sands of the middle and upper Pliocene were apparently deposited by streams coming from the southwest and the northeast. The shallow Pliocene sands are well developed low on the northeast flank of Elk Hills (wells 41-30T and 321-26S, pl. 4). Many thin discontinuous sands may wedge out against the north flank of the Eastern anticline. Judging by well 18-6R (pl. 14), the Pliocene sandstones are not well developed at the northwest end of the reserve, and shallow stratigraphic traps are less likely in this area.

\section{DEEP ZONES}

The Elk Hills structure has been described as a drag fold resulting from wrench-fault tectonic movement along the San Andreas fault (Moody and Hill, 1956; Moody, 1973, p. 454). Basement is invariably involved in wrench-fault deformation, and a swath of terrane is deformed prior to and concurrently with strike slip along the wrench fault (Wilcox and others, 1973, p. 74). Because of continued activity along the San Andreas fault, probably beginning in the Jurassic and extending to the present, the formation of drag folds has been a continuing process. Structural highs have developed along with the deposition of potentially petroliferous beds. Some major drag folds along the San Andreas fault were being actively uplifted throughout Tertiary time, and oil accumulations are present in rocks of nearly all stage (Moody, 1973, p. 471). If Elk Hills is a drag fold produced by the San Andreas fault, structural traps should be present in beds between middle Miocene rocks and basement.

According to Moody (1973, p. 471), a consequence of continuous growth of drag folds is the creation of stratigraphic traps along the flanks of the growing folds. Such traps are found on the flanks of the several folds of the Midway-Sunset area, for example (fig. 28). The Olig sand at Elk Hills is a classic example of a sandstone pinchout against the flank of an anticline (fig. 37), and it is interesting to compare the zero-sand line of the Olig with the crest of the structure of the Reef Ridge Shale (pl. 4).

Production from fields adjacent to the east and west ends of Elk Hills makes it apparent that, in upward order, the Point of Rocks Sandstone Member, the Wygal Sandstone Member, and the lower and middle parts of the Santos Shale Member are prospective hydrocarbon reservoirs. All units below the Santos (table 3), except for the Welcome Shale Member, are productive in the southwest San Joaquin Valley area, and all, except for the Gredal Shale Member, are present in at least some of the wells adjacent to Elk Hills. Nearly the entire section below presently productive beds from the Santos Shale Member to basement could provide additional oil and gas. Exploratory wells to depths of 15,000-18,000 feet are needed to add the third dimension now lacking in any evaluation of the petroleum potential of Naval Petroleum Reserve No. 1.

The Carneros Sandstone Member of the Temblor Formation is present and productive on the Western anticline but grades eastward into shale before reaching the North Coles Levee area. A considerable amount of Carneros sandstone with oil shows was cored as far east as well 542-31S in the Elk Hills field; these shows suggest that oil may have accumulated in this sandstone beneath NPR-1 in combination structural and stratigraphic traps.

The Wygal Sandstone Member of the Temblor Formation, a prolific reservoir along the west side of the San Joaquin Valley, is 456 feet thick in the Railroad Gap field, 50 feet thick in the Asphalto field, and is apparently absent in the North Coles Levee field. The sandstone evidently pinches out beneath the Elk Hills field and has good potential for stratigraphic as well as structural traps.

The possibility of deep production at Elk Hills is enhanced by the fact that deep production has been found adjacent to both the east and west ends of the field in the North Coles Levee and Railroad Gap fields (fig. 51). At North Coles Levee the Richfield Oil Corporation well 67-29T. was drilled to a total depth of 17,895 feet and completed flowing oil from the Eocene Point of Rocks Sandstone Member of the Kreyenhagen Formation between 17,620 feet and the top of the basement complex at 17,873 feet (Hardoin, 1962, p. 55). A collapsed casing forced the abandonment of this reservoir. Oil was also recovered from the middle and lower beds in the Santos Shale Member of the Temblor Formation of Oligocene and Miocene age. The final completion was made in 
Miocene rocks. The stratigraphically deepest production at Elk Hills is from the upper beds of the Santos Shale Member. On the basis of the North Coles Levee deep well, a major part of the Oligocene and all Eocene rocks are good exploration objectives at Elk Hills.

At the Railroad Gap field, the Oligocene Wygal Sandstone Member ("Phacoides" sand) of the Temblor Formation has been found productive. In the same field the Point of Rocks Sandstone Member of the Kreyenhagen Formation (table 4) has been found to be 1,938 feet thick and nonproductive. This same sandstone produced appreciable amounts of oil in well $67-29 \mathrm{~T}$ in the North Coles Levee field, where it is only 379 feet thick. The Point of Rocks may be a thick sheet sand across Elk Hills and is a prime exploration objective that should be tested by any deep exploratory holes that may be drilled in NPR-1.

\section{REFERENCES CITED}

Addicott, W. O., 1972, Biostratigraphy and correlation of Tertiary sandstones at Big Tar Canyon, Reef Ridge, California, in Guidebook to geology and oil fields of west side central San Joaquin Valley: Am. Assoc. Petroleum Geologists-Soc. Explor. Geophysicists-Soc. Econ. Paleontologists and Mineralogists, Pacific Sec., 47th Ann. Mtg., Bakersfield, Calif., 1972, p. 65-69.

Adegoke, O. S., 1969, Stratigraphy and paleontology of the marine Neogene formations of the Coalinga region, California: California Univ. Pubs. Geol. Sci., v. 80, 269 p.; 1970, Dissert. Abs. Internat., Sec. B, Sci. and Eng., v. 31, no. 2, p. 755B-756B.

Adkison, W. L., 1973, Lithologic characteristics of upper Oligocene and Miocene rocks drilled at Elk Hills, Kern County, California: U.S. Geol. Survey Bull. 1375, 113 p.

American Association of Petroleum Geologists-Society of Economic Paleontologists and Mineralologists, Pacific Sec., 1968, Guidebook to geology and oil fields of west side southern San Joaquin Valley, 43d Ann. Mtg., Bakersfield, Calif., 1968: 142 p.

Anderson, D. N., 1963, Stevens pool of Asphalto oil field [Kern County]: California Oil Fields, v. 49, no. 1, 5-10.

Anderson, F. M., 1905, A stratigraphic study in the Mount Diablo Range of California [western border of San Joaquin Valley]: California Acad. Sci. Proc., 3d ser., v. 2, 248 p.

1908, A further stratigraphic study in the Mount Diablo Range [Contra Costa County] California: California Acad. Sci. Proc., 4th ser., v. 3, p. 1-40.

Anderson, Robert, 1912, Preliminary report on the geology and possible oil resources of the south end of the San Joaquin Valley, California: U.S. Geol. Survey Bull. 471-A-5, p. 106-136.

Armstrong, T. A., 1964a, Railroad Gap, best California find in the last 15 years [Kern County]: Oil and Gas Jour.,- v. 62, no. 28, p. 132-133.

__ 1964b, New California field [Railroad Gap] looks better every day: Oil and Gas Jour., v. 62, no. 37, p. 173.

Arnold, Ralph, 1909, Paleontology of the Coalinga district, Fresno and Kings Counties, California: U.S. Geol. Survey Bull. 396, $173 \mathrm{p}$.

Arnold, Ralph, and Anderson, Robert, 1908, Preliminary report on the Coalinga oil district, Fresno and Kings Counties, California: U.S. Geol. Survey Bull. 357, 142 p.

1910, Geology and oil resources of the Coalinga district [Fresno County], California: U.S. Geol. Survey Bull. 398, 354 p.

Arnold, Ralph, and Garfias, V. R., 1914, Geology and technology of the
California oil fields: Am. Inst. Mining Metall. Engineers Bull., v. 87, p. $383-467$.

Arnold, Ralph, and Johnson, H. R., 1910, Preliminary report on the McKittrick-Sunset oil region, Kern and San Luis Obispo Counties, California: U.S. Geol. Survey Bull. 406, 225 p.

Atwill, E. R., 1935, Oligocene Tumey Formation of California [Fresno County]: Am. Assoc. Petroleum Geologists Bull., v. 19, no. 8, p. 1192-1204.

Bailey, W. C., 1939, Wasco oil field [California]: California Oil Fields, v. 24 , no. 3 , p. $66-71$.

Ball, M. W., 1917, Petroleum withdrawals and restorations affecting the public domain: U.S. Geol. Survey Bull. 623, $444 \mathrm{p}$.

1926, History of the Naval Oil Reserves: Am. Inst. Mining Metall. Engineers, Petroleum Devel. Technology 1925, p. $779-784$.

Bandy, O. L., and Arnal, R. E., 1969, Middle Tertiary basin development, San Joaquin Valley, California: Geol. Soc. America Bull., v. 80, no. 5, p. 783-819; 1968, Am. Geophys. Union Trans. [abs.], v. 49, no. 1, p. 244; 1968, Am. Assoc. Petroleum Geologists Bull. [abs.], v. 52 , no. 3, p. 518 .

Baptist, O. C., and Smith, C. R., 1965, Effect of gas saturation on the pressure gradient in the oil zone: Soc. Petroleum Engineers of AIME, Dallas. Preprint Calif. Regional Mtg., Bakersfield, Calif., Nov. 4-5, 1965.

Barbat, W. F., 1932, Age of producing horizon at Kettleman Hills [Kern County], California: Am. Assoc. Petroleum Geologists Bull., v. 16 , no. 6 , p. $611-612$.

1971, Megatectonics of the Coast Ranges, California: Geol. Soc. America Bull., v. 82, no. 6, p. 1541-1561.

Barbat, W. F., and Galloway, John, 1934, San Joaquin clay, California: Am. Assoc. Petroleum Geologists Bull., v. 18, no. 4, p. 476-499.

Barbat, W. F., and Johnson, F. L., 1933, Stratigraphy and Foraminifera of Reef Ridge Shale, California [abs.]: Pan-Am. Geologist, v. 59 , no. 3 , p. 239.

1934, Stratigraphy and Foraminifera of the Reef Ridge Shale, Upper Miocene, California: Jour. Paleontology, v. 8, p. 3-17.

Bateman, P. C., and Wahraftig, Clyde, 1966, Geology of the Sierra Nevada, in Bailey, E. H., ed., Geology of Northern California: California Div. Mines and Geology Bull. 190, p. 107-172.

Bates, J. L., 1963, The origins of Teapot Dome: Urbana, Ill., Univ. Illinois Press, $278 \mathrm{p}$.

Beck, R. S., 1950; Stratigraphic correlation chart, San Joaquin Valley (Oligocene-Pleistocene): Bakersfield, Calif., Earl M. Price and Co.

Berryman, W. M., 1973, Lithologic characteristics of Pliocene rocks cored at Elk Hills, Kern County, California: U.S. Geol. Survey Bull. 1332-D, 56 p.

Blake, W. P., 1855, Notice of remarkable strata containing the remains of Infusoria and Polythalmia in the Tertiary formation of Monterey, California: Acad. Nat. Sci. Philadelphia Proc., v. 7, p. 328-331.

Bouma, A. H., 1962, Sedimentology of some flysch deposits, a graphic approach to facies interpretation: Amsterdam/New York, Elsevier Pub. Co., $168 \mathrm{p}$.

Bunch, E. S., 1944, Navy's Elk Hills [California] reserve tapped to meet critical oil shortage: Oil Weekly, v. 115 , no. 5, p. 36-46.

Burke, R. J., and Gardner, F. J., 1969, The world's monster oil fields and how they rank: Oil and Gas Jour., v. 67, no. 2, p. 43-49.

Butterfield, O. R., 1967, Management of the Naval Petroleum and Oil Shale Reserves; maintaining a potential: Jour. Petroleum Technology, v. 19 , no. 3, p. 297-306.

California Division of Mines and Geology, 1965, Geologic map of California, Bakersfield sheet: scale $1: 250,000$.

California Division of Oil and Gas, 1968, Map 414, Elk Hills, scale $1: 2,000$. 
Callaway, D. C., 1968, Habitat of oil on the west side, San Joaquin Valley, California, in Guidebook to geology and oil fields of west side southern San Joaquin Valley: Am. Assoc. Petroleum Geologists-Soc. Explor. Geophysicists-Soc. Econ. Paleontologists and Mineralogists, Pacific Sec., 43d Ann. Mtg., Bakersfield, Calif., 1968, p. 21-25.

Caraway, W. H., and Gates, G. L., 1959, Methods for determining water contents of oil-bearing formations: Rept. of Inv. 5451, U.S Bur. Mines. 81 p.

Church, C. C., 1931, Foraminifera of the Kreyenhagen shale: Mining in California, v. 27, no. 2, p. 202-213.

Church, H. V., Jr., and Krammes, K. F., chm., and others, 1957, Cenozoic correlation section across south San Joaquin Valley from San Andreas fault to Sierra Nevada foothills, California: Am. Assoc. Petroleum Geologists, Pacific Sec., scale 1 inch to $1 \frac{1 / 2}{2}$ mile.

-1958, Correlation sections longitudinally north-south thru central San Joaquin Valley from Rio Vista thru Riverdale (10 north), and Riverdale thru Tejon Ranch area (10 south), California: Am. Assoc. Petroleum Geologists, Pacific Sec., scale about 1 inch to 3 miles.

-1959, Correlation section longitudinally north-south thru west side San Joaquin Valley from Coalinga to Midway-Sunset and across San Andreas fault into southeast Cuyama Valley, California: Am. Assoc. Petroleum Geologists, Pacific Sec., scale 1 inch to 2,000 feet.

Clark, B. L., 1929, Tectonics of the Valle Grande [Great Valley] of California: Am. Assoc. Petroleum Geologists Bull., v. 13, no. 3, p. 199-238: 1928, Pam-Am. Geologist [abs.], v. 49, no. 4, p. 304.

Clarke, Samuel, and Nilsen, Tor H., 1972, Postulated offsets of Eocene strata along the San Andreas fault zone, central California: Geol. Soc. America, Abs. with Programs; Cordilleran Sec., 68th Ann. Mtg., v. 4, no. 3, p. 137-138.

Cloos, Ernst, 1968, Experimental analysis of Gulf Coast fracture patterns: Am. Assoc. Petroleum Geologists Bull., v. 52, no. 3, p. 420-444.

Collom, R. E., 1921, The Elk Hills oil field [Kern County]: California Oil Fields, v. 7 , no. 1 , p. 5-6.

Compton, R. R., 1966, Granitic and metamorphic rocks of the Salinian Block, California Coast Ranges, in Bailey, E. H., ed., Geology of Northern California: California Div. Mines and Geology Bull. 190 , p. 277-287.

Connor, J. J., and Gerrild, P. M., 1971, Geochemical differentiation of crude oils from six Pliocene sandstone units, Elk Hills U.S. Naval Petroleum Reserve No. 1, California: Am. Assoc. Petroleum Geologists Bull., v. 55, no. 10, p. 1802-1813.

Cooper, H. N., 1904, Chemical analysis of California petroleum: California State Mining Bur. Bull. 31, 1 sheet.

Cordell, R. J., 1972, Depths of oil origin and primary migration; A review and critique: Am. Assoc. Petroleum Geologists Bull., v. 56, no. 10, p. 2029-2067.

Croft, M. G., 1969, Subsurface geology of the late Tertiary and Quaternary water-bearing deposits of the southern part of the San Joaquin Valley, California: U.S. Geol. Survey open-file report, $29 \mathrm{p}$.

Cunningham, G. M., and Barbat, W. F., 1932, Age of producing horizon at Kettleman Hills, California: Am. Assoc. Petroleum Geologists Bull., v. 16 , no. 4, p. 417-421.

Curran, J. F., 1943, Eocene stratigraphy of the Chico Martinez Creek area, Kern County, California: Am. Assoc. Petroleum Geologists Bull., v. 27, no. 10, p. 1361-1386.

Cushman, J. A., and Barbat, W. F., 1932, Notes on some arenaceous Foraminifera from the Temblor Formation of California [Kern County]: Cushman Lab. Foram. Research Contr., v. 8, pt. 2, p. $29-40$.
Cushman, J. A., and Goudkoff, P. P., 1938, A new species of Pulvinulinella from the California Miocene: Cushman Lab. Foram. Research Contr., v. 14, no. 1, p. 1 2.

Dale, R. H., French, J. J., and Gordon, G. V., 1966, Ground-water geology and hydrology of the Kern River alluvial-fan area, California: U.S. Geol. Survey open-file report, $92 \mathrm{p}$.

Davis, C. A., 1952, The North Coles Levee field pressure maintenance project: Jour. Petroleum Technology, v. 4, no. 8, p. 11.

Davis, G. H., and others, 1959, Ground-water conditions and storage capacity in the San Joaquin Valley, California: U.S. Geol. Survey Water-Supply Paper 1469, 287 p.

Department of the Navy, 1973, Annual report calendar year 1972 Naval Petroleum Reserves 1 and 2;.Kern County, California: Naval Petroleum Reserves, Elk Hills, California, p. I-1-III-20.

Dibblee, T. W., Jr., 1955, Geology of the southeastern margin of the San Joaquin Valley, California, Art. 2, in Pt. 1 of Oakeshott, G. B., ed., Earthquakes in Kern County, California, during 1952 California Div. Mines Bull. 171, p. 23-34.

1966, Evidence for cumulative offset on the San Andreas fault in central and northern California, in Bailey, E. H., ed., Geology of northern California: California Div. Mines and Geology Bull. 190 , p. $375-383$.

1968, Geologic map of Temblor Range, San Luis Obispo and Kern Counties, California, in Guidebook to geology and oil fields of west side southern San Joaquin Valley: Am. Assoc. Petroleum Geologists-Soc. Econ. Paleontologists and Mineralogists, Pacific Sec., 43d Ann. Mtg., Bakersfield, Calif., 1968: in pocket.

1969, Regional geologic map of southern Coast Ranges near San Andreas fault from Cholame to Maricopa, Santa Barbara, San Luis Obispo, Kern and Kings Counties, California: U.S. Geol. Survey open-file map (revised 9/11/69).

-1972 , Geologic maps of fourteen 15-minute quadrangles along the San Andreas fault in the vicinity of Paso Robles, and Cholame southeastward to Maricopa and Cuyama, California: U.S. Geol. Survey open-file report, 13 sheets and index map, scale 1:62,500. 1973, Stratigraphy of the southern Coast Ranges near the San Andreas fault from Cholame to Maricopa,.California: U.S. Geol. Survey Prof. Paper 764, 45 p.

Dosch, M. W., 1962, South Coles Levee oil field [Kern County]: California Oil Fields, v. 48, no. 2, p. 63-72.

Doyle, F. F., 1927, Elk Hills-some notes on the development of one of the richest oil and gas districts in California: Oil, v. 13, no. 11, p. 1155-1156.

Eastman, M. C., and Ruhlman, F. L., 1949, Experimental production projects and exploratory drilling at Elk Hills [California]: Am. Inst. Mining Metall. Engineers Trans., v. 179, p. 329-356.

Eldridge, G. H., 1903, The petroleum fields of California: U.S. Geol. Survey Bull. 213, p. 306-321.

Elk Hills Engineering:Committee, 1957a, Shallow Oil Zone, second revision dated May 1, 1957, of estimated recoverable oil and participations as of November 20, 1942, in Unit operations-Naval Petroleum Reserve No. 1 (Elk Hills), Kern County, California: Bakersfield, Calif., Elk Hills Eng. Comm., 35 p., 1 fig., 18 maps.

1957b, Stevens Zone, estimated recoverable oil and second revision of percentage participations as of November 20,1942, in Unit operations-Naval Petroleum Reserve No. 1 (Elk Hills), Kern County, California: Bakersfield, Calif., Elk Hills Eng. Comm., 42 p., 1 fig., 22 maps.

Elliott, W. J., Tripp, Eugene, and Karp, S. E., 1968, Road guides-west side oil fields and Temblor Range outcrop .area, in Guidebook to geology and oil fields of west side southern San Joaquin Valley: Am. Assoc. Petroleum Geologists-Soc. Explor. Geophysicists-Soc. Econ. Paleontologists and Mineralogists, Pacific Sec., 43d Ann. Mtg., Bakersfield, Calif., 1968, p. 104-130. 
English, W. A., 1918, Geology and oil prospects of the Salinas Valley-Parkfield area, California: U.S. Geol. Survey Bull. 691-H, p. 219-250.

Fishburn, M. D., 1973, Dry Gas Zone: Tupman, Calif., Naval Petroleum Reserves in California, $25 \mathrm{p}$.

Foss, C. D., 1972, A preliminary sketch of the San Joaquin Valley stratigraphic framework, in Guidebook to geology and oil fields of west side central San Joaquin Valley: Am: Assoc. Petroleum Geologists-Soc. Explor. Geophysicists-Soc. Econ. Paleontologists and Mineralogists, Pacific Sec., 47th Ann. Mtg., Bakersfield, Calif., 1972 , p. $40-50$.

Foss, C. D., and Blaisdell, Robert, 1968, Stratigraphy of the west side, southern San Joaquin Valley, in Guidebook to geology and oil fields of west side southern San Joaquin Valley: Am. Assoc. Petroleum Geologists-Soc. Explor. Geophysicists-Soc. Econ. .Paleontologists and Mineralogists, Pacific Sec., 43d :Ann. Mtg., Bakersfield, Calif., 1968, p. 33-43.

Frost, E. M., Jr., 1946, Helium tracer studies in the Elk Hills [Kern County] field: Oil and Gas Jour., v. 45, no. 8, p. 107.

Galliher, E. W., 1931, Collophane from the Miocene Brown Shale of California: Am. Assoc. Petroleum Geologists Bull.; v. 15, no. 3, p. 257-265.

Gester, G. C., 1917, Geology of a portion of the McKittrick district [Kern County], a typical example of west side, San Joaquin Valley oil fields, and a correlation of the oil sands of the west side fields: California Acad. Sci. Proc., v. 4, no. 7, p. 207-227.

Gester, G. C., and Galloway, John, 1933, Geology of Kettleman Hills oil field [Kern County], California: Am. Assoc. Petroleum Geologists Bull., v. 17, no. 10, p. 1161-1193.

Gooch, F. W., Jr., and Adams, R. H., 1955, Report of operations, 1945 through 1954, -Naval Petroleum Reserve No. 1, Elk Hills, California: Jour. Petroleum Technology, v. 7, no. 11, p. 13-20.

Goudkoff, P. P., 1931, Age of producing horizon at Kettleman Hills, California: Am. Assoc. Petroleum Geologists Bull., v. 15, no. 7 p. 839-842.

1934, Subsurface stratigraphy of Kettleman Hills oil field, California: Am. Assoc. Petroleum Geologists Bull., v. 18, no. 4, p. 435-475.

1943, Correlation of oil-field formations on west side of San Joaquin Valley [California]: California Div. Mines Bull. 118, p. $-247-252$

Gussow, W. C., 1955, Time of migration of oil and gás: Am. Assoc. Petroleum Geologists Bull., v. 39, no. 5, p. 547-574.

1968, Migration of reservoir fluids: Jour. Petroleum Technology, April 1968, p. 353-363.

Gustafson, W. M., 1953, Black Gold for the Navy, Petroleum Reserve No. 1, Elk Hills [California]: U.S. Navy Civil Engineer Corps Bull., Jan. 1953, p. 4.

Hackel, Otto, 1966, Summary of the geology of the Great Valley [California], in Bailey, E. H., ed., Geology of northern California: California Div. Mines and Geology Bull. 190, p. 217-238.

Halbouty, M. T., ed., 1970, Geology of giant petroleum fields, a symposium: Tulsa, Okla., Am. Assoc. Petroleum Geologists, $575 \mathrm{p}$.

Hamlin, Homer, 1904, Water resources of the Salinas Valley, California: U.S. Geol. Survey Water-Supply and Irrig. Paper 89, 91 p.

Hanna, G. D., 1926, Further notes on Scalez petrolia: Nautilus, v. 40, p. 14-16.

1928, The Monterey shale of California at its type:locality, with a summary of its fauna and flora: Am. Assoc. Petroleum Geologists Bull., v. 12, no. 10, p. 969-983.

Hanna, G. D., and Gaylord, E. G., 1924, Description of a new genus and species of freshwater gastropod mollusk (Scalez petrolia from the Etchegoin Pliocene of California): California Acad. Sci., Proc., 4 th ser., v. 13 , no. 9 , p. 147-149.
Hardoin, J. L., 1962, North Coles Levee oil field [Kern County]: California Oil Fields, v. 48, no. 2, p. 53-61.

1965, Railroad Gap oil field [Kern County]: California Oil Fields, v. 51, no. 1, p. 5-12.

Heckel, P. H., 1972, Recognition of ancient shallow marine environments, in Recognition of ancient sedimentary environments: Soc. Econ. Paleontologists and Mineralogists, Spec. Pub. No. 16, p. 226-286.

Heikkila, H. H., and MacLeod, G. M.; 1951, Geology of Bitterwater Creek area, Kern County, California: California Div. Mines Spec. Rept. 6, 21 p.

Henny, Gerard, 1930, McLure Shale of the Coalinga region, Fresno and Kings Counties, California: Am. Assoc. Petroleum Geologists Bull., v. 14, no. 4, p. 402-410.

Hight, William, 1933, Elk Hills field, in Graphic history, development and production of California oil fields: California Oil World, v. 25, no. 43, p. 8,15 .

Hill, M. L., 1971, A test of new global tectonics; comparisons of northeast Pacific and California structures: Am. Assoc. Petroleum Geologists Bull., v. 55, no. 1, p. 3-9.

Hobson, H. D., 1951, Sacramento Valley: Am. Assoc. Petroleum Geologists Bull., v. 35, no. 2, p. 209-214.

Hoots, H. W., 1930, Geology and oil resources along the southern border of San Joaquin Valley, California: U.S. Geol. Survey Bull. 812-D, p. 243-332.

Hoots, H. W., Bear, T. L., and Kleinpell, W. D., 1954, Geological summary of the San Joaquin Valley, California,[pt. 8], in Chap. 2 of Jahns, R. H., ed., Geology of southern California: California Div. Mines Bull. 170, p. 113-129.

Hoots, H. W., and Herold, S. C., 1935, Natural gas resources of California, in Geology of natural gas, a symposium: Tulsa, Okla., Am. Assoc. Petroleum Geologists, p. 113-220.

Irwin, W. P., 1957, Franciscan group in Coast Ranges and its equivalents in Sacramento Valley, California: Am. Assoc. Petroleum Geologists Bull., v. 41, no. 10, p. 2284-2297.

Ise, John, 1926, The United States oil policy: New Haven, Conn., Yale University Press, $547 \mathrm{p}$.

Jenkins, O. P., 1931, Stratigraphic significance of the Kreyenhagen shale of California: Mining in California, v. 27, no. 2, p. 141-186; 1931, Geol. Soc. America Bull. [abs.], v. 42, no. 1, p. 303-304.

Johnson, H. R., 1909, Geology of the McKittrick-Sunset district' [Kern County], California [abs.]: Science, n.s., v. 30, p. 63-64.

Kilkenny, J. E., 1951, San Joaquin Valley, in Ball, M. W., ed., Possible future Petroleum provinces of North America: Am. Assoc. Petroleum Geologists Bull., v. 35, no. 2, p. 215-218.

Kleinpell, R. M., 1938, Miocene stratigraphy of California: Tulsa, Okla., Am. Assoc. Petroleum Geologists, 450 p.

Lantz, R. J., 1968, A review of the Elk Hills oil field, Kern County, California, in Guidebook to geology and oil fields of west side southern . San Joaquin Valley: Am. Assoc. Petroleum Geologists-Soc. Explor. Geophysicists-Soc. Econ. Paleontologists and Mineralogists, Pacific Sec., 43d Ann. Mtg., Bakersfield, Calif.; 1968, p. 49-53; abs., Am. Assoc. Petroleum Geologists Bull., v. 53 , no. 3 , p. 563 .

Lawrence, C. J., 1964, Asphalto field, a "guts and imagination" discovery [Kern County]: Oil and Gas Jour., v. 62, no. 1, p. 34-35.

LeConte, Joseph, 1948, Geophysical history of the North Coles Levee oil field, Kern County, California: Geophys. Case Histories, v. 1, p. 554-560.

Loomis, A. G., and Crowell, D. C.. 1962, Relative permeability studies; gas-oil and water-oil systems: U.S. Bur. Mines Bull. 599, 39 p.

Lorshbough, A. L., 1967, Western portion of Elk Hills oil field [Kern County, California]: California Oil Fields, v. 53, no. 1, p. 33-37.

Louderback, G. D., 1913, The Monterey series in California: California Univ. Dept. Geol. Sci. Bull., v. 7, p. 177-241. 
McBride, E. F., 1963, A classification of common sandstones: Jour Sed. Petrology, v. 33, no. 3, p. 664-669.

McCulloh, T. H., 1973, Oil and gas, in United States mineral resources, U.S. Geol. Survey Prof. Paper 820, p. 477-496.

McLaughlin, R. P., 1919, Natural gas development in the Elk Hills, Kern County, California: California Oil Fields, 4th Ann. Rept. California State Mining Bur., p. 4-8.

McLaughlin, R. P. , and Waring, C. A., 1914, Petroleum industry of California: California Div. Mines Bull. 69, 519 p.

McMasters, J. H., 1943, Buena Vista Hills area of the Midway-Sunset oil field [California]: California Div: Mines Bull. 118, pt. 3, p. 517-518.

McMichael, L. B., and others, 1959, Chico Martinez Creek area, California: Guidebook to San Joaquin Geol. Soc. Field Trip, May 9, 1959, $15 \mathrm{p}$.

Maher, J. C., Carter, R. D., and Lantz, R. J., 1972, Late Tertiary structural development at Elk Hills oil field, Kern County, California, in Geological Survey research 1972: U.S. Geol. Survey Prof. Paper 800-C, p. C71-C78.

Maher, J. C., and Trollman, W. M., 1968, Geologic literature on the San Joaquin Valley of California: U.S. Geol. Survey open-file report, $398 \mathrm{p}$

Maher, J. C., Trollman, W. M., and Denman, J. M., 1973, Geologic literature on the San Joaquin Valley of California: Northern California Geol. Soc. and Am: Assoc. Petroleum Geologists, Pacific Sec., 582 p.

Mallory, V. S., 1959, Lower Tertiary biostratigraphy of the California Coast Ranges: Tulsa, Okla., Am. Assoc. Petroleum Geologists, $416 \mathrm{p}$.

Martin, Bruce, 1912, Fauna from the type locality of the Monterey series in California: California Univ. Dept. Geology Bull., v. 7, no. 7, p. $143-150$.

May, A. R., and Gilboe, J. D., 1931, Foraminifera at the type section of the Temblor formation, Carneros Creek area, Kern County, California: Stanford Univ. Dept. Geology ms.

Merriam, J. C.; 1915, Tertiary vertebrate faunas of the north Coalinga region of Califormia: Am. Philos. Soc. Trans., v. 22, pt. 3, p. 1-44.

Mirchink, M. F., and others, 1971, Main concepts of the theory of oil and gas origin and their accumulation in the light of the most recent investigations: World Petroleum Cong., 8th; Moscow, Proc., v. 2, p. 27-33.

Moody, J. D., 1973, Petroleum exploration aspects of wrench-fault tectonics: Am. Assoc. Petroleum Geologists Bull., v. 57, no. 3, p. 449-476.

Moody, J. D., and Hill, M. J., 1956, Wrench-fault tectonics: Geol. Soc. America Bull., v. 67, no. 9, p. -1207-1246.

Moore, J. G., 1959, The quartz diorite boundary line in the western United States, Jour. Geology, v. 67, no. 2, p. 198-210.

Natland, M. L., 1957, Paleoecology of West Coast [Calif.] Tertiary sediments [chap. 19] in Ladd, H. S., ed., Paleoecology, Volume 2 of Treatise on marine ecology and paleoecology, Geol. Soc. America Mem. 67, p. 543-571.

Noble, E. B., 1940, Rio Bravo oil field, Kern County, California: Am. Assoc. Petroleum Geologists Bull., v. 24, no. 7, p. 1330-1333; slightly revised, 1943, California Div. Mines Bull. 118, pt. 3, p. $556-558$.

Nomland, J. O., 1917, The Etchegoin Pliocene of middle California: California Univ. Pubs. Geol. Sci., v. 10, no. 14, p. 191-254.

Oil and Gas Journal, 1941, Cross section and field data of active oil areas, southern San Joaquin Valley, California (includes crosssection across the San Joaquin Valley, by J. C. Bransford): Oil and Gas Jour., v. 40, no. 25, p. 40-B.

1943, Production suspended in Coles Levee field of Kern County: Oil and Gas Jour., v. 41, no. 36, p. 78-79. 1944a, Standard's deep test now below old state record [Coles Levee, Kern County]: Oil and Gas Jour., v. 43, no. 23, p. 135.

1944b, Standard's deep test reaches 15,389 feet [Elk Hills, Kern County]: Oil and Gas Jour., v. 43, no. 25, p. 123

-1944c, Standard's deep test reaches 15,542 feet: Oil and Gas Jour., v. 43, no. 26, p. 139-140.

1944d, Standard's deep test reaches 15,702 feet [Kern County]: Oil and Gas Jour., v. 43, no. 27, p. 126-127.

-1945 , Elk Hills exploration assured by appropriation: Oil and Gas Jour., v. 44, no. 9, p. 147.

$-1946 \mathrm{a}, \mathrm{Navy}$ soon to complete another Stevens sand well [Kern County]: Oil and Gas Jour., v. 44, no. 46, p. 139-140.

1946b, New sand discovery extends North Coles Levee field: Oil and Gas Jour., v. 45, no. 5, p. 142.

-1953a, Elk Hills problem-high pressure water driving oil out. of field: Oil and Gas Jour., v. 51, no. 43, p. 45.

1953b, Deepest pay found [North Coles Levee field, Kern County]: Oil and Gas Jour.., v. 52, no. 29, p. 96.

1954a, 1,000th well completed in Naval Petroleum Reserve No. 1 [Elk Hills]: Oil and Gas Jour., v. 52, no. 43, p. 43.

-1954b, Shut-in field growing [Elk Hills, Naval Petroleum Reserve No. 1]: Oil and Gas Jour., v. 52, no. 45, p. 92.

1962, Apparent oil strike made in California's San Joaquin Valley [Kern County, Asphalto field]: Oil and.Gas Jour., v. 60, no. 51, p. 150 .

1963a, New pool found [Kern County]: Oil and Gas Jour., v. 61, no. 6, p. 168 .

1963b, Asphalto sets fast pace [Kern County]: Oil and Gas Jour., v. 61, no. 11, p. 209

1963c; Navy joins California play [Kern County]: Oil and Gas Jour., v. 61, no. 16 , p. 173.

O'Neill, D. B., 1952, Pressure maintenance at the North Coles Levee field [Kern County]: Jour. Petroleum Technology, v. 4, no. 2, p. 19.

Pack, R. W., 1920, The Sunset-Midway oil field, California; Pt. 1, Geology and oil resources: U.S. Geol. Survey Prof. Paper 116, 179 p.; J. D. Sears, Washington Acad. Sci. Jour. [abs.], v. 11, no. 3, p. 58.

Page, B. M., 1966, Geology of the coast ranges of California, in Bailey, E. H., ed., Geology of northern California: California Div. Mines and Geology Bull. 190, p. 255-276.

Park, W. H., and Land, P. E., 1955, Correlation sections of west side fields of Kern County [A-A, Devils Den to McDonald Anticline; B-B, McDonald Anticline to Lost Hills; C-C, North Belridge to Belgian Anticlines; D-D, Temblor Ranch to Wasco; E-E, Belgian Anticline to Midway-Sunset; F-F, Midway-Sunset to North Coles Levee; G-G, Bowerbank Gas to Paloma]: California Oil Fields, v. 41, no. 1, p. 32 .

Pemberton, J. R., 1929, Elk Hills, Kern. County, California, in Structure of typical American oil fields: Tulsa, Okla., Am. Assoc. Petroleum Geologists, Sidney Powers Memorial Volume 2, p. 44-61.

Petroleum Times, 1932, Elk Hills oil field of California: Petroleum Times, v. 28, p. 668.

Porter; L. E., 1943, Elk Hills oil field [U.S. Naval Petroleum Reserve No. 1] [California]: California Div. Mines Bull. 118, pt. 3, p. $512-516$.

Prutzman; P. W., 1904, Production and use of petroleum in California: California Div. Mines Bull. 32, 230 p., 14 maps.

Quarles, Miller, Jr., 1953, Saltridge hypothesis on origin of Texas Gulf Coast type of faulting: Am. Assoc. Petroleum Geologists Bull., v. 37, no. 3, p. 489-508.

Ragland, R. W., 1944, A history of the naval petroleum reserves and of the development of the present national policy respecting them, Washington, D.C., U.S. Navy, Office of Naval Petroleum and Oil Shale Reserves, $180 \mathrm{p}$. 
Reed, R. D., 1933, Geology of California: Tulsa, Okla., Am. Assoc. Petroleum Geologists, 355 p.; reprint 1951, 355 p.

Reed, R. D., and Hollister, J. S., 1936, Structural evolution of southern California: Tulsa, Okla., Am. Assoc. Petroleum Geologists; 157 p.

Regan, L. J., 1953, Fractured shale reservoirs of California [southwest San Joaquin Valley]: Am. Assoc. Petroleum Geologists Bull., v. 37 , no: 2, p. 201-216.

Repenning, C. A., 1960, Geologic summary of the central valley of California with reference to the disposal of liquid radioactive waste: U.6. Geol. Survey TEI-769, 69 p.

Requa, M. L., 1911, California oil field conditions and production, 1875-1910: Am. Inst. Mining Metall. Engineers Trans., v. 42, p. $837-846$.

Richardson, J. O., 1916, Naval Petroleum Reserves No. 1 and No. 2: U.S. Naval Institute, Annapolis, Md., Proc., v. 42, p. 93-123.

Rintoul, W. T., 1967a, Midway-Sunset heads for the winner's circle: California Oil World, v. 60, no. 5, p. 1-6.

1967b, Kern oil field news: Bakersfield (Calif.) Californian, Aug. 25, 1967.

Roberts, D. C., 1927, Fossil markers of Midway-Sunset-Elk Hills region in Kern County, California: California Oil Fields, v. 12, no. 10 , p. $5-10$

Rose, R. L., and Colburn, I. P., 1963, Geology of the east-central part of the Priest Valley quadrangle, California, in Guidebook to geology of Salinas Valley and the San Andreas fault: Am. Assoc. Petroleum Geologists-Soc. Econ. Paleontologists and Mineralogists, Pacific Sec., 38th Ann. Mtg., Los Angeles, Calif., 1963, p. 38-45.

San Joaquin Geological Society, 1959, Chico Martinez Creek area [Kern County], California: Guidebook to San Joaquin Geol. Soc. Field Trip, May 9, 1959, 15 p.

Sanders, T. P., 1941, Navy will plug recently awarded Elk Hills wells: Oil and Gas Jour., v. 40 , no. 4 , p. 38.

Saunders, L. W., 1925, Recent developments in the east end of Elk Hills oil field: California Oil Fields, v. 10, no. 11, p. 5-11.

Seiden,.Hy, 1965a, Asphalto-a sleeper among giants [Kern County] Am. Assoc. Petroleum Geologists, Pacific Sec., 40th Ann. Mtg., Bakersfield, Calif., 1965, p. 4-15.

1965b, The Asphalto field [Kern County] [abs.]: Am. Assoc Petroleum Geologists-Soc. Explor. Geophysicists-Soc. Econ. Geologists and Mineralogists, Pacific Sec., Program, 40th Ann. Mtg., Bakersfield, Calif., 1965, p. 26; Am. Assoc. Petroleum Geologists Bull., v. 49, no. 7, p. 1089-1090.

Sheldon, W. C., and Sutton, J. H., 1957, South Coles Levee unit cycling project, South Coles Levee field, Kern County, California: Am. Petroleum Inst. Proc., Div. Production, v. 243, p. 141-151.

Siegfus, S. S., 1939, Stratigraphic features of Reef Ridge shale in southern California [San Joaquin Valley]: Am. Assoc. Petroleum Geologists Bull., v. 23, no. 1, p. 24-44:

Silverman, S. R., 1971, Influence of petroleum origin and transformation on its distribution and redistribution in sedimentary rocks World Petroleum Cong., 8th, Moscow, Proc., v. 2, p. 47-54.

Simonson, R. R., 1958, Oil in the San Joaquin Valley, California, in Weeks, L. G., ed., Habitat of oil: Tulsa, Okla., Am. Assoc. Petroleum Geologists, p. 99-112.

Simonson, R. R., and Krueger, M. L., 1942, Crocker Flat landslide area, Temblor Range, California: Am. Assoc. Petroleum Geologists Bull. v. 26, no. 10, p. 1608-1631.

Smith, H. P., 1956, Foraminifera from the Wagonwheel formation, Devils Den district [Northwest Kern County], California: California Univ. Pubs. Geol. Sci., v. 32, no. 2, p. 65-125.

Stanton, R. J., and Dodd, J. R., 1972, Pliocene cyclic sedimentation in the Kettleman Hills, California, in Guidebook to geology and oil fiëlds of west side central San Joaquin Valley: Am. Assoc. Pe- troleum Geologists-Soc. Explor. Geophysicists-Soc. Econ. Paleontologists and Mineralogists, Pacific Sec., 47th Ann. Mtg., Bakersfield, Calif., 1972, p. 50-58.

Stewart, R. B., 1946, Geology of Reef Ridge, Coalinga district, California: U.S. Geol. Survey Prof. Paper 205-C, p. 81-115.

Stockman, L. P., 1942a, Five-mile west outpost at Elk Hills completed as gas well [Kern County]: Oil and Gas Jour., v. 40, no. 37, p. 54 $-1942 \mathrm{~b}$, Reserves in Elk Hills may be greatly increased by new find [Kern County]:Oil and Gas Jour., v. 40, no. 51, p. 216.

1945, Proposed exploratory work would help determine extent of Elk Hills [Kern County] reserve: Oil and Gas Jour., v. 43, no. 42 , p. $157-160$.

Stormont, D. H., 1954, Reservoir problem-migration and mixing of oil and water in Elk Hills field [Kern County]: Oil and Gas Jour., v. 53 , no. 22 , p. 106.

Stratton, D. H., 1957, Behind Teapot Dome; some personal insights: Business History Rev. v. 31 (winter 1957), p. 385-402.

Sullwold, H. H., 1961, Turbidites in oil exploration, in Geometry of sandstone bodies, Tulsa, Okla., Am. Assoc. Petroleum Geologists, p. $63-81$.

Taliaferro, N. L., and Barbat, W. F., 1946, Notes on the geology of the deep Coles Levee well, Kern County, California [abs.]: Am. Assoc. Petroleum Geologists Bull., v. 30, no. 1, p. 132.

Thoms, C..C., and Smith, F. M., 1922, Notes on Elk Hills oil field: California State Mining Bur. State Mineralogists Rept., 7th, 1921, p. $7-19$.

Tracie, R. G., 1937, History of the Naval petroleum reserves: Washington, 'Dept. Navy, 413 p.

Twisselmann, E.C., 1968, An introduction to the flora and vegetation of the western San Joaquin Valley, in Guidebook to geology and oil fields of west side southern San Joaquin Valley: Am. Assoc. Petroleum Geologists-Soc. Explor. Geophysicists-Soc. Econ. Paleontologists and Mineralogists, Pacific Secs., 43d Ann. Mtg., Bakersfield, Calif., 1968, p. 11-16.

U.S. Congress, Senate Committee on Public Lands and Surveys, 1924, . Leases upon Naval oil reserves, Hearings (Senate Resolution 282 and 294): U.S. 67th Cong., 4th sess., 14 pts. (in 4 v.).

Van Couvering; Martin, and Allen, H. B., 1943, Devils Den oil field [Kern County], California Div. Mines Bull. 118, pt. 3,p. 496-501.

Vander Leck, L., 1921, Petroleum resources of California with special reference to unproved areas: California Div. Mines Bull. 89, 186 p., map scale $1 \frac{1}{2} 2$ inches to 50 miles.

Wagner, Paul, 1923, Elk Hills outstanding reserve in still important San Joaquin Valley: Națl. Petroleum News, v. 15, p. 23-26 (May 2, 1923).

Warren, G. A., ed., 1938, Decisions of the Department of the Interior, v. 55 [Oct. 1, 1934-Sept. 9, 1936]: Washington, U.S. Govt. Printing Office, $652 \mathrm{p}$.

Watts, W. L., 1894, The gas and petroleum yielding formations of the central valley of Califormia: California Mining Bur. Bull. 3, $100 \mathrm{p}$. 1901, Oil and gas yielding formations of California; Part 7, The San Joaquin Valley: California Mining Bur. Bull. 19, p. 106-142.

Wells, J. C., 1951, Geology of Elk Hills, Kern County [California] [abs.]: Am. Assoc. Petroleum Geologists Bull., v. 35, no. 12, p. 2634

1952, Elk Hills field [Kern County]: Am. Assoc. Petroleum Geologists-Soc. Econ. Paleontologists and Mineralogists-Soc. Explor. Geophysicists Guidebook, Field Trip, 37th Ann. Mtg., Los Angeles, Calif., 1952, p. 241-245.

Welsh, G. B., and Thomas, J. F., 1960, Significance of chemical limits in United States Public Health Service drinking water standards: Am. Water Works Assoc. Jour., v. 52, no. 2, p. 289-300.

White, G. T., 1962, Formative years in the far west: New York, Appleton-Century-Crofts, $694 \mathrm{p}$. 
Wilcox, R. E., Harding, T. P., and Seely, D. R., 1973, Basic wrench tectonics: Am. Assoc. Petroleum Geologists Bull., v. 57, no. 1, p. 74-96.

Williams, R. N., Jr., 1936, Recent developments in the North Belridge oil field: California Oil Fields, v. 21, no. 4, p. 5-16.

Willis, B., 1927, Folding or shearing, which?: Am. Assoc. Petroleum Geologists Bull., v. 11, no. 1, p. 31-47.

Wood, P. R., and Dale, R. H., 1964, Geology and ground-water features of the Edison-Maricopa area, Kern County, California: U.S. Geol. Survey Water-Supply Paper 1656, $108 \mathrm{p}$.

Wood, P. R., and Davis, G. H., 1959, Ground-water conditions in the Avenal-McKittrick area, Kings and Kern Counties, California: U.S. Geol. Survey Water-Supply Paper 1457, v. 4, 141 p.

Woodring, W. P., 1926, Pliocene Viviparus-like opercula from California: Nautilus, v. 39, no. 4, p. 109-111.

Woodring, W. P., and Roundy, P. V.,1927, Geology and oil development of the Elk Hills, California [abs.]: Washington Acad. Sci.
Jour., v. 17 , no. 10 , p. 271-272.

Woodring, W. P., Roundy, P. V., and Farnsworth, H. R., 1932, Geology and oil resources of the Elk Hills, California, including Naval Petroleum Reserve No. 1: U.S. Geol. Survey Bull. 835, 82 p.

Woodring, W. P., Stewart, R. B., and Richards, R. W., 1940, Geology of the Kettleman Hills oil field, California, stratigraphy, paleontology and structure: U.S. Geol. Survey Prof. Paper 195, 170 p.

Woodward, W. T., 1945, Southeastern part of the Midway-Sunset oil field, California: U.S. Geol. Survey Oil and Gas Inv. Prelim. Map OM-30, scale 1 inch to 2000 feet.

Zeni, Milton, and Cunningham, J. S., 1967, Railroad Gap area-new reserves in old province [McKittrick, Kern County, California]: Am Assoc. Petroleum Geologists-Soc. Econ. Paleontologists and Mineralogists, Pacific Sec., Program, 42d Ann. Mtg., Los Angeles, Calif., 1967, p. 109.

Zulberti, J. L., 1956, McKittrick oil field [Kern County, California]: California Oil Fields, v. 42 , no. 1 , p. $49-60$. 